\title{
Ecology of Juvenile Salmonids in Shallow Tidal Freshwater Habitats in the Vicinity of the Sandy River Delta, Lower Columbia River, 2007
}

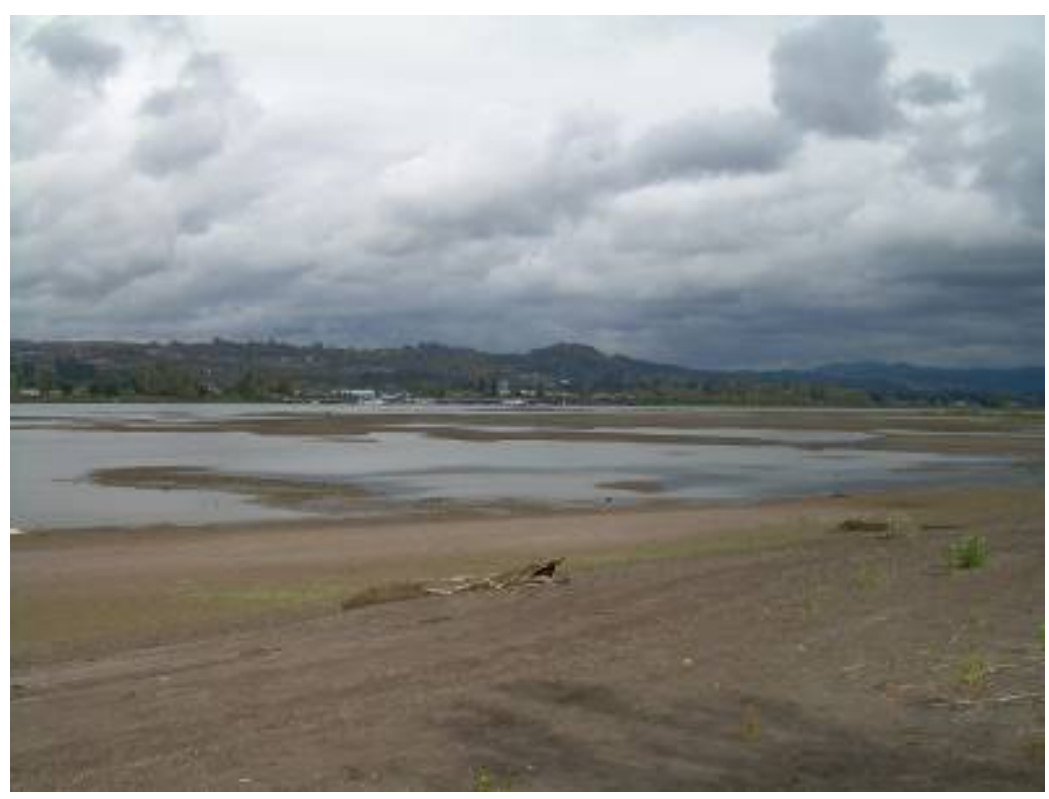

Annual Report

March 18, 2008

Prepared for the Bonneville Power Administration

Under a Related Services Agreement

with the U.S. Department of Energy

Contract DE-AC05-76RLO1830

\section{Pacific Northwest}

\section{National Laboratory}

Operated by 3attelle for the

U.S. Department of Energy 


\section{DISCLAIMER}

This report was prepared as an account of work sponsored by an agency of the United States Government. Neither the United States Government nor any agency thereof, nor Battelle Memorial Institute, nor any of their employees, makes any warranty, express or implied, or assumes any legal liability or responsibility for the accuracy, completeness, or usefulness of any information, apparatus, product, or process disclosed, or represents that its use would not infringe privately owned rights. Reference herein to any specific commercial product, process, or service by trade name, trademark, manufacturer, or otherwise does not necessarily constitute or imply its endorsement, recommendation, or favoring by the United States Government or any agency thereof, or Battelle Memorial Institute. The views and opinions of authors expressed herein do not necessarily state or reflect those of the United States Government or any agency thereof.

PACIFIC NORTHWEST NATIONAL LABORATORY

operated by BATTELLE for the

UNITED STATES DEPARTMENT OF ENERGY

under Contract DE-AC05-76RL01830 


\title{
Ecology of Juvenile Salmonids in Shallow Tidal Freshwater Habitats in the Vicinity of the Sandy River Delta, Lower Columbia River, 2007
}

\author{
Annual Report
}

March 18, 2008

Kathryn Sobocinski ${ }^{1}$

Gary Johnson ${ }^{1}$

Nichole Sather ${ }^{1}$

Adam Storch $^{2}$

Tucker Jones ${ }^{2}$

Christine Mallette ${ }^{2}$

Earl Dawley ${ }^{3}$

John Skalski ${ }^{4}$

David Teel $^{5}$

Paul Moran ${ }^{5}$

1 Pacific Northwest National Laboratory

2 Oregon Department of Fish and Wildlife

3 Fisheries Consultant

4 University of Washington

${ }^{5}$ National Marine Fisheries Service

Prepared for the Bonneville Power Administration

Under a Related Services Agreement

with the U.S. Department of Energy

Contract DE-AC05-76RLO1830

Pacific Northwest National Laboratory

Marine Sciences Laboratory

Sequim, Washington 98382 
$\longrightarrow$ 


\section{Executive Summary}

This document is the first annual report for the study titled "Ecology of Juvenile Salmonids in Shallow Tidal Freshwater Habitats in the Vicinity of the Sandy River Delta in the Lower Columbia River.” Hereafter, we refer to this research as the Tidal Freshwater Monitoring (TFM) Study. The study is part of the research, monitoring, and evaluation effort developed by the Action Agencies (Bonneville Power Administration, U.S. Army Corps of Engineers, U.S. Bureau of Reclamation) in response to obligations arising from the Endangered Species Act as a result of operation of the Federal Columbia River Power System (FCRPS). The project is performed under the auspices of the Northwest Power and Conservation Council’s Columbia Basin Fish and Wildlife Program.

\section{Goal and Objectives}

The goal of the 2007-2009 Tidal Freshwater Monitoring Study is to answer the following questions: In what types of habitats within the tidal freshwater area of the lower Columbia River and estuary (LCRE; Figure 1) are yearling and subyearling salmonids found, when are they present, and under what environmental conditions? ${ }^{1}$ And, what is the ecological importance ${ }^{2}$ of shallow (0-5 m) tidal freshwater habitats to the recovery of Upper Columbia River spring Chinook salmon and steelhead and Snake River fall Chinook salmon? Research in 2007 focused mainly on the first question, with fish stock identification data providing some indication of Chinook salmon presence at the variety of habitat types sampled. The objectives and sub-objectives for the 2007 study were as follows:

\section{Habitat and Fish Community Characteristics-Provide basic data on habitat and fish} community characteristics for yearling and subyearling salmonids at selected sites in the tidal freshwater reach in the vicinity of the Sandy River delta.

1a. Characterize vegetation assemblage percent cover, conventional water quality, substrate composition, and beach slope at each of six sampling sites in various tidal freshwater habitat types.

1b. Determine fish community characteristics, including species composition, abundance, and temporal and spatial distributions.

${ }^{1}$ This question was recommended by the Independent Scientific Review Panel (ISRP 2005).

${ }^{2}$ Ecological importance refers to the effects that habitat structures have on ecosystem processes and functions (Thom 1987; Thom 2000). In the present case, ecological importance is defined as how the substrate, water velocity regime, bathymetry, vegetation, prey resources, etc. in the LCRE influence juvenile salmon production, growth, and survival. Thom et al. (2004) provide a conceptual ecosystem model that outlines these relationships. 
1c. Estimate the stock of origin for the yearling and subyearling Chinook salmon captured at the sampling sites using genetic analysis.

1d. Statistically assess the relationship between salmonid abundance and habitat parameters, including ancillary variables such as temperature and river stage.

2. Acoustic Telemetry Monitoring-Assess feasibility of applying Juvenile Salmon Acoustic Telemetry System (JSATS) technology to determine migration characteristics from upriver of Bonneville Dam through the study area (vicinity of the Sandy River delta/Washougal River confluence).

2a. Determine species composition, release locations, and distributions of JSATS-tagged fish.

2b. Estimate run timing, residence times, and migration pathways for these fish.

Additionally, both objectives serve the purpose of baseline research for a potential tidal rechannelization project on the Sandy River. The U.S. Forest Service, in partnership with the Bonneville Power Administration and the U.S. Army Corps of Engineers, is currently pursuing reconnection of the east (relict) Sandy River channel with the current channel to improve fish and wildlife habitat in the Sandy River delta. Our study design and the location of sampling sites in this reach provide baseline data to evaluate the potential restoration.

\section{Background}

Shallow water habitats (0-5 m) in the tidal freshwater portion of the Lower Columbia River and Estuary (LCRE) are thought to be of importance for the growth and survival of both stream-type (yearling migrant) and ocean-type (subyearling migrant) life histories of salmon. Scientific knowledge specifically addressing this hypothesis, however, is sparse and current monitoring efforts are fragmented. The tidal freshwater portion of the Columbia River Estuary (from approximately rkm 56 to Bonneville Dam) is little studied compared to the lower estuary and tributaries. Uncertainties regarding migration characteristics and habitat use of Pacific salmon in this reach remain. A loss of shallow water habitats throughout the lower Columbia River due to diking and FCRPS operation may mean a considerable loss of rearing opportunity for juvenile salmon. Additionally, interactions between salmon and other fish species in this reach have not been well described.

Our study area lies within the upper tidal freshwater portion of the Columbia River in the vicinity of the Sandy and Washougal Rivers, extending from rkm 193 to 201. Within this reach there are floodplain, island, shallows, and river confluence habitats. This reach was selected because of the diversity of habitats, relatively little fish work has been conducted in this portion of the tidal freshwater reach of the river, and there is a potential habitat restoration action in the Sandy River delta for which baseline fish data could be informative. 


\section{Methods}

Our sampling efforts began in June 2007 and continue on at present time; this report summarizes data collected between June 2007 and December 2007. To address Objective 1 of our study, monthly sampling at six sites (Figure A) consisted of fish collection (including abundance, lengths on a subset of fish collected, and fin clips for genetics analysis) and collection of ancillary data related to water level, in-water conditions, and habitat conditions. Additionally, habitat characterizations including topographic data collection and vegetation assessment were conducted at each site once. To address Objective 2 of our study, acoustic nodes were deployed from April to August at a sub-set of sites; while we did not tag any fish as part of this study, the nodes were set to detect fish tagged as part of other studies when they passed near our sites.

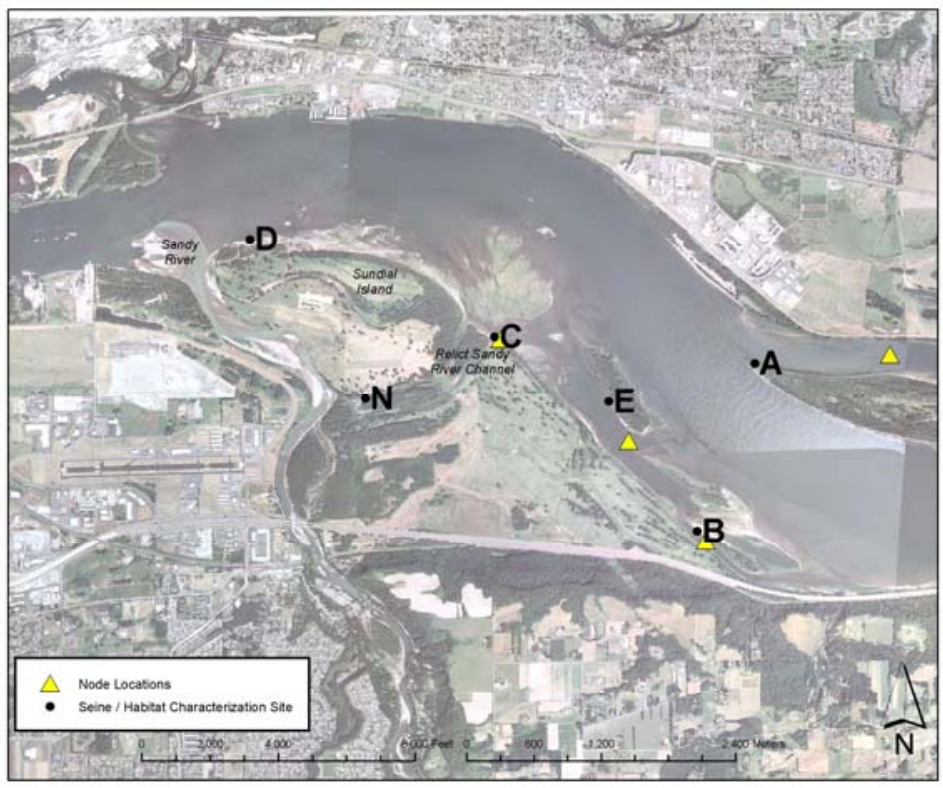

Figure A. Sampling Sites in the Vicinity of the Sandy River Delta, Columbia River

\section{Results}

Our sites differed in beach slope and presence of submerged aquatic vegetation (SAV), with two sites (B and E) having considerably steeper beach slope (and thus water depth) and more SAV than the other sites. Sediment characteristics were similar at all sites, although Site D had a high proportion of larger sediments (gravel) than the other sites. Vegetation species were similar throughout the study area, though assemblages at specific sites varied, with Sites A and E being characterized by simple bands of a few species and Sites $\mathrm{C}$ and $\mathrm{N}$ consisting of numerous species in small patches. The relationship between elevation and vegetation species occurrence was described 
for these sites and the arrangement of species at any given site is likely driven by fine-scale changes in topography.

The fish data show that species occurrence and abundance vary by site and date. We captured a total of 23 species over our sampling period. The most dominant species captured include threespine stickleback (Gasterosteus aculeatus), banded killifish (Fundulus diaphanous), peamouth (Mylocheilus caurinus), northern pikeminnow (Ptychocheilus oregonensis), and bluegill (Lepomis macrochirus). These dominant species were present in beach seine catches during all months of the study period and were also found at each of the six sampling locations. Many (40\%) of the species we collected are not native to the Columbia River. While not a large portion of our catch, we captured three Amur gobies (Rhinogobius brunneus) at Site N. This species is of concern because it is a recently introduced species and its potential impacts are not well understood.

Chinook salmon (Oncorhynchus tshawytscha) were found at each of the six sampling sites at the beginning and end of the sampling period, but were absent in July, September, and October; only one Chinook salmon was captured in August. Coho salmon (O. kisutch) were encountered at all sites except Sites A and D; with the exception of one coho salmon that was found at Site N in June, all coho salmon catches occurred during November and December. The relative lack of salmon captured during our sampling period precludes conclusive site differences; likewise, change in mean fork length over time is inconclusive due to the lack of fish collected during the summer months and the likelihood of different stocks or life-history patterns migrating through our sites over time. Nonetheless, we captured juvenile salmon during winter (December) at Sites C and E in shallow, tidal freshwater of the lower Columbia River.

Genotypic data were collected on 108 Chinook salmon. At each site and date, multiple stocks were collected. Most of the Chinook analyzed were from local stock groups (West Cascade Tributaries, including the Sandy River, Lewis River and Cowlitz Hatchery and Willamette River, including the McKenzie Hatchery and River, North Santiam Hatchery and River and the North Fork of the Clackamas River). A large component of the fish we analyzed were from the Upper Columbia River Summer/Fall stock group; it is important to note that fish from this stock group are released throughout Bonneville Pool hatcheries. Likewise, some Willamette River stock group fish are released from hatcheries on the Sandy River.

The 2007 acoustic telemetry data demonstrate the feasibility of using this technique to detect fish for the purpose of investigating migration characteristics in shallow, off-channel habitats in the lower Columbia River. A total of 577 yearling and subyearling Chinook salmon implanted with JSATS transmitters and released at Bonneville (545 of 577) and Lower Granite (32 of 577) dams had valid detections at the acoustic nodes in the study area. Most fish were detected at the Reed Island node, followed by the Gary Island node. Eight fish were present near the node at the old Sandy delta (mouth of the old river channel). Residence time, as estimated by the mean duration between first and last valid detections, was about $1 \mathrm{~h}$ for subyearlings and $4 \mathrm{~h}$ for yearlings released at Bonneville Dam. Migration pathway data indicated that the majority of the JSATS-tagged fish detected at both arrays bracketing the study area-89\% of the yearlings and $96 \%$ of the subyearlings — used the main 
river channel; a portion of the tagged fish (9\% yearlings and 3\% subyearlings) apparently used the route between Reed Island and the Washington shore. A fraction of the yearlings and subyearlings, $3 \%$ and $0.3 \%$, respectively, used the route along the Oregon shore at the Sandy delta and Gary Island.

\section{Recommendations}

While beach seining proved to be a successful method of capturing fish in our shallow water areas, we offer the following recommendations that will allow us to discriminate sampling bias from variation between sites: further sampling over greater spatial and temporal scales should reduce the variance in the data; different gear types could be used to evaluate the role of large predators in structuring yearling and subyearling salmon populations; diet analyses should be conducted to shed light on the strength of inter- and intra-specific competition at our sites, and help elucidate potential implications of competitive interactions; comparative evaluation of different gear types and deployment methods will help maximize sampling efficiency; employing PIT-tag detection equipment in the study areas could provide a significant addition to data collection in future years.

We have the following recommendations to improve the acoustic telemetry technique for application in shallow, off-channel habitats: perform drag tests with transmitters at known positions (depth, distance, direction) relative to a given node; deploy a beacon transmitter near some or all of the nodes to monitor receiver performance; research and develop a receiving node for shallow water; disguise and bury tag lines to fixed, autonomous nodes in shallow water to minimize interference from non-project beach-goers; and, perform a retrospective analysis of the criterion for determining a valid detection event for the data from the off-channel nodes used in this study.

This study is scheduled to continue in 2008 and 2009. The monthly fish community sampling and genetic stock identification of salmonids, periodic habitat characterizations, and seasonal acoustic telemetry should be maintained. Additionally, research on juvenile salmonid diets will provide an indication of usage of shallow, tidal freshwater habitats. 


\section{Preface}

The Bonneville Power Administration (BPA) contracted with the Pacific Northwest National Laboratory (PNNL) to perform this study (BPA Project No. 2005-001-00; Contract No. 26934 release 7). In turn, PNNL subcontracted with Earl Dawley, the National Marine Fisheries Service (NMFS), the Oregon Department of Fish and Wildlife (ODFW), and the University of Washington (UW). The study originated in August 2005 to 1). design a sampling scheme, 2.) initiate the collection permit process, and 3.) to coordinate the Conference on Research, Monitoring, and Restoration in the Lower Columbia River, Estuary, and Nearshore Ocean held in Astoria, Oregon during April 2006. We submitted a proposal for the FY07-09 solicitation for the Northwest Power and Conservation Council's Fish and Wildlife Program. Subsequently, the project was funded by BPA as a "Biological Opinion” project in 2007, the first year of field work for the study. For more information about this project, please contact Kathryn Sobocinski (360-681-4588).

\section{Acknowledgments}

We appreciate the important contributions to this project made by many colleagues. Blaine Ebberts (U.S. Army Corps of Engineers, Portland District, [USACE]) loaned the acoustic receiving nodes. Terri Gilbride (PNNL) reviewed and edited the report. Jan Slater (PNNL) managed the contract. Tracey Yerxa (BPA) represented the contracting officer and has diligently and effectively supported the project. The U.S. Forest Service (USFS) provided access to Sundial Island. Lee Miller (PNNL) provided GIS support. Dave Nichols provided boat support for the habitat characterization Finally, this research would not have been possible without the beach seine and habitat characterization field crews, including Robert Brooks, Londi Tomaro, and Ruth Farr (ODFW), Amy Borde, Shon Zimmerman, and Jimmie Cotton (PNNL).. 


\section{Acronyms}

$\begin{array}{ll}\begin{array}{l}\text { AFEP - Anadromous Fish Evaluation Program } \\ \text { ANOVA - analysis of variance }\end{array} & \begin{array}{c}\text { LCREP - Lower Columbia River Estuary } \\ \text { Partnership }\end{array} \\ \text { BACI - before-after, control-impact } & \text { LCRE - lower Columbia River and estuary } \\ \text { BPA - Bonneville Power Administration } & \text { NMFS - National Marine Fisheries Service } \\ \text { CSMEP - Collaborative Systemwide } & \text { NOAA - National Oceanic and Atmospheric } \\ \text { Monitoring and Evaluation Project } & \text { Administration } \\ \text { CWT - coded-wire tag } & \text { NPCC - Northwest Power and Conservation } \\ \text { ESA - Endangered Species Act } & \text { Council } \\ \text { ESU -- evolutionarily significant unit } & \text { ODFW - Oregon Department of Fish and } \\ \text { FCRPS - Federal Columbia River Power } & \text { Wildlife } \\ \text { System } & \text { PIT - passive integrated transponder } \\ \text { FL - fork length } & \text { PNAMP - Pacific Northwest Aquatic } \\ \text { FY - fiscal year } & \text { Monitoring Partnership } \\ \text { GIS - geographic information system } & \text { PNNL - Pacific Northwest National } \\ \text { GPS - global positioning system } & \text { Laboratory } \\ \text { ISAB - Independent Scientific Advisory Board } & \text { RTK - real-time kinematic } \\ \text { ISRP - Independent Scientific Review Panel } & \text { USACE - US Army Corps of Engineers } \\ \text { JSATS -- Juvenile Salmon Acoustic Telemetry } & \text { USGS - U.S. Geological Survey } \\ \text { System } & \text { UW - University of Washington } \\ \text { LCFRB - Lower Columbia Fish Recovery } & \\ \text { Board } & \end{array}$




\section{Table of Contents}

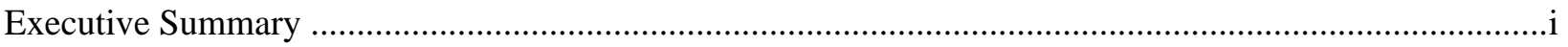

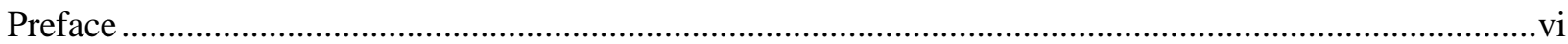

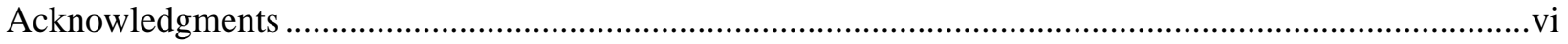

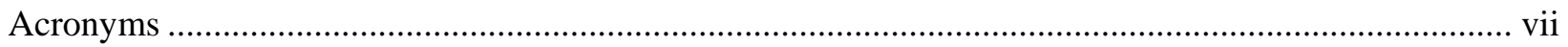

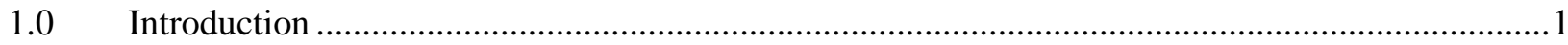

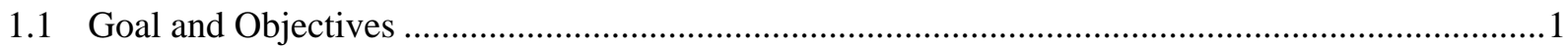

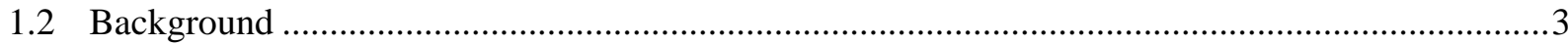

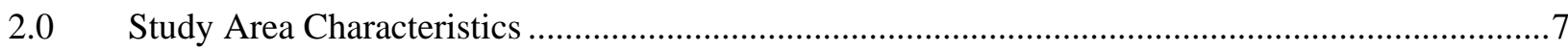

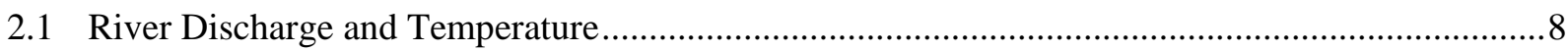

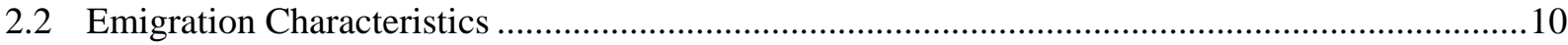

2.2.1 Species Composition and Run Timing ….........................................................................10

2.2.2 Nearby Hatchery Fish Releases ...................................................................................10

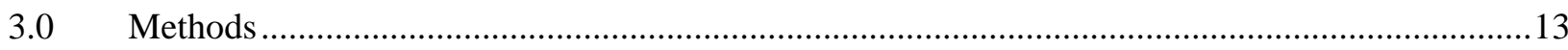

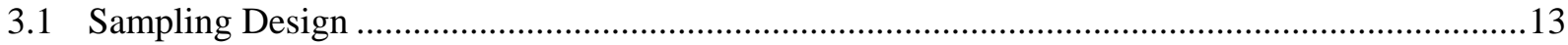

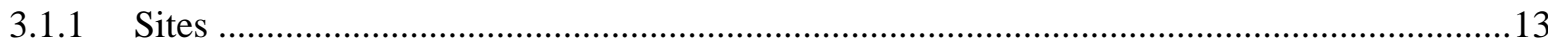

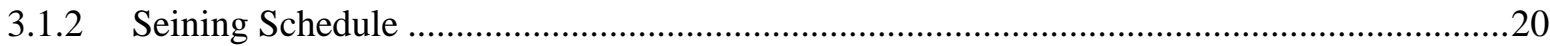

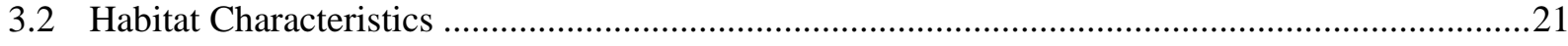

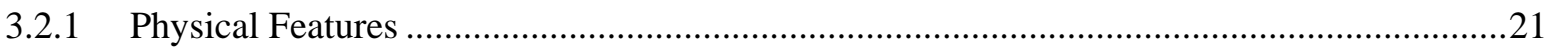

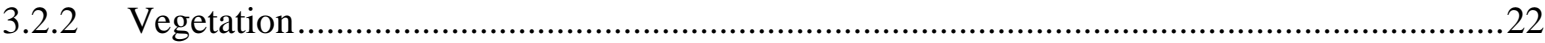

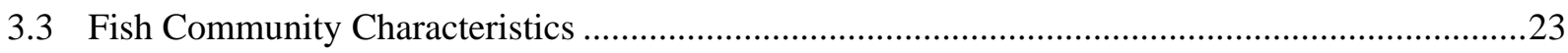

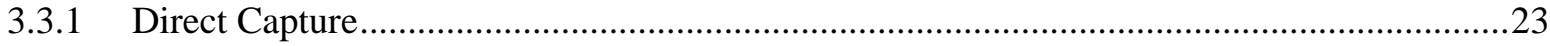

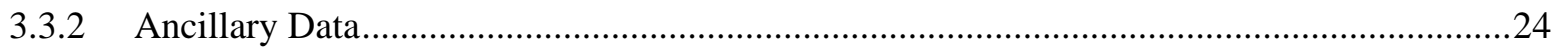

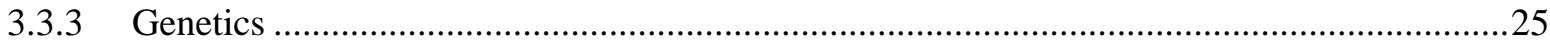

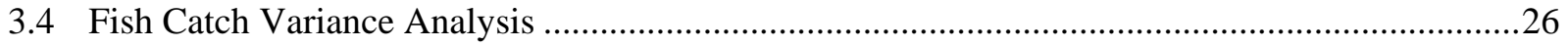

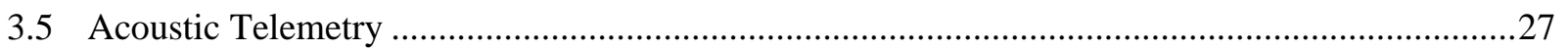

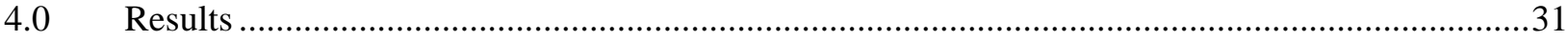

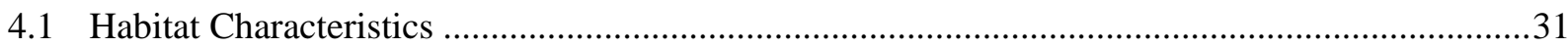




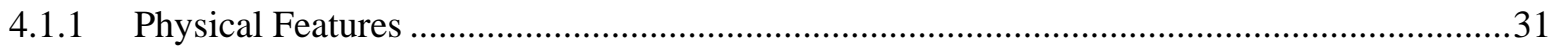

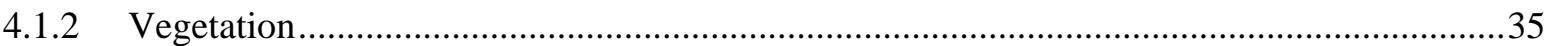

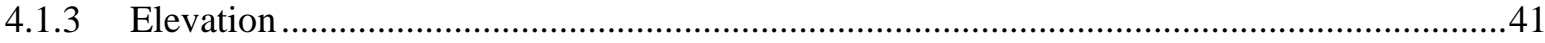

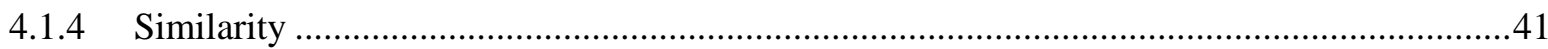

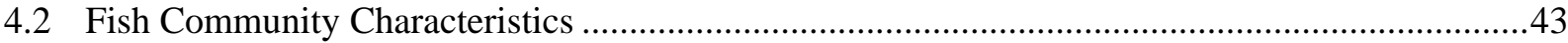

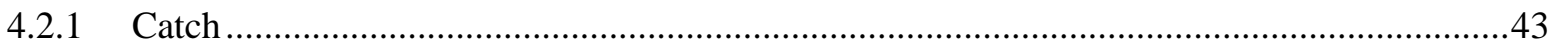

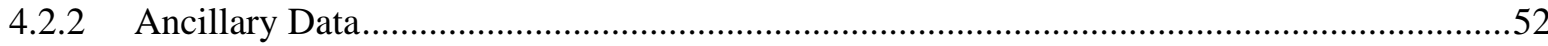

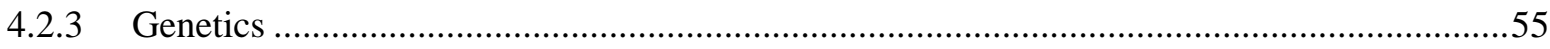

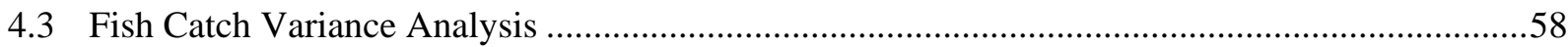

4.3.1 Variance-to-Mean Relationships ….............................................................................58

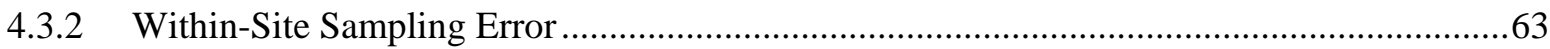

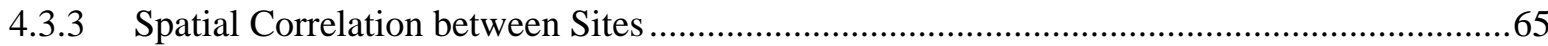

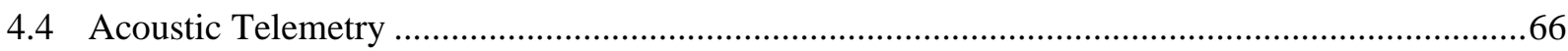

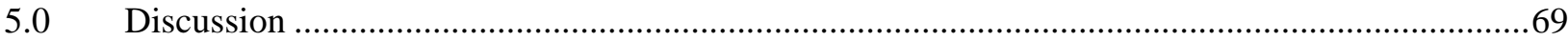

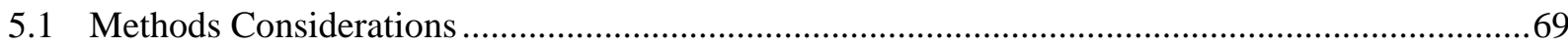

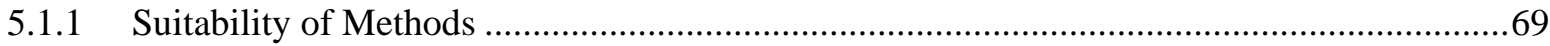

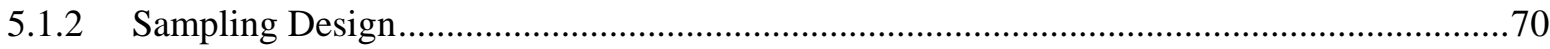

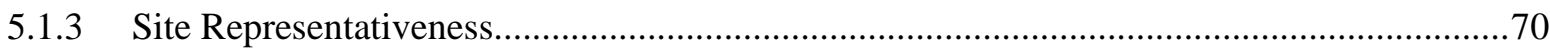

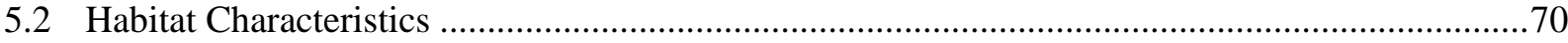

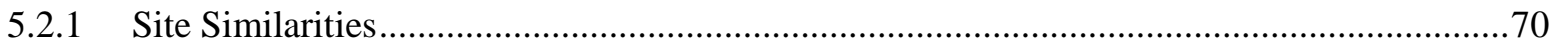

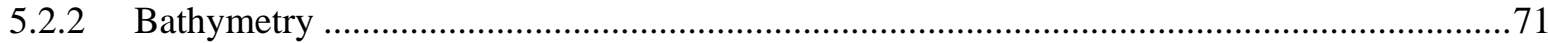

5.3 Fish Community Characteristics ………................................................................................

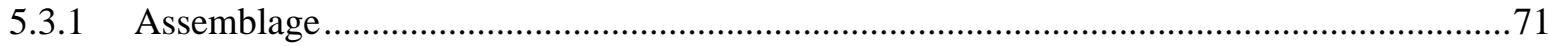

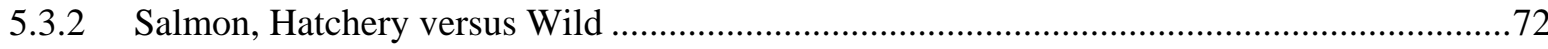

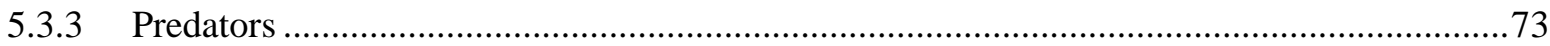

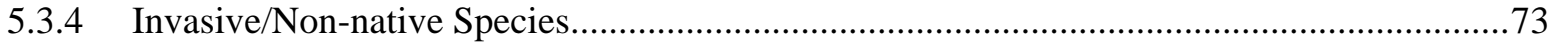

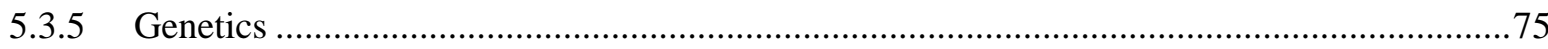

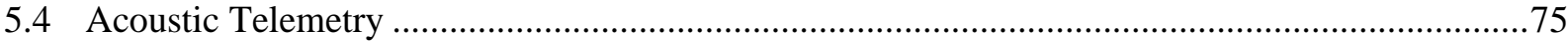

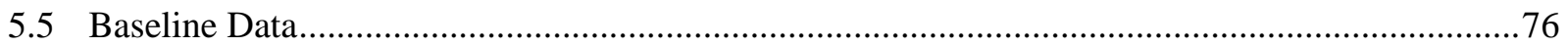




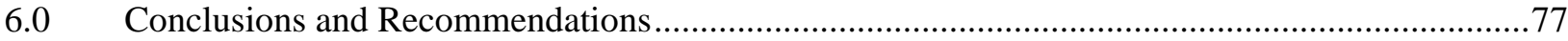

6.1 Fish Sampling and Habitat Characterization .....................................................................................

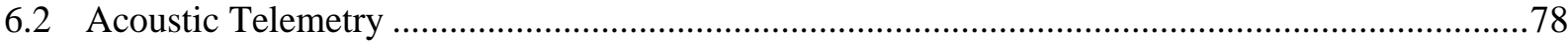

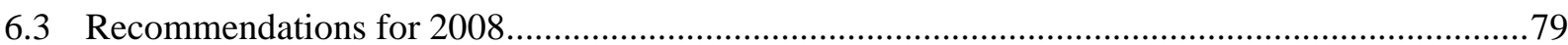

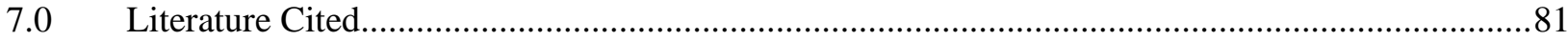

Appendix A: Relationships to Other Programs and Projects …..............................................................1

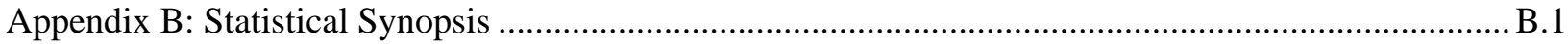

Appendix C: Beach Seine Catch and Ancillary Data ...............................................................................

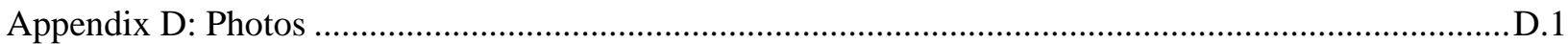

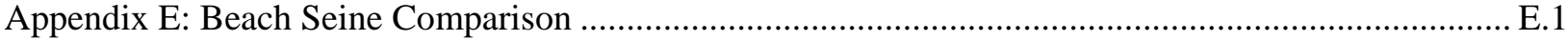

\section{Figures}

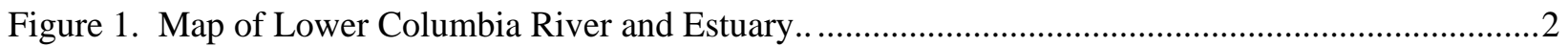

Figure 2. Focal Reach in the LCRE, in the Vicinity of the Sandy River................................................

Figure 3. Outflow (kcfs) at Bonneville Dam, 2007..............................................................................

Figure 4. A) Scroll Case river temperature measured at Bonneville Dam, 2007. B) Columbia

River outflow measured at Bonneville Dam, 2007 (Columbia River DART 2008a). C)

Columbia River gage height measured at Vancouver, WA (USGS 2008).................................9

Figure 5. 2007 Bonneville Dam Smolt Monitoring Index (DART 2008b) …........................................10

Figure 6. 2007 Salmon Hatchery Releases in the Vicinity of the Study Area (DART 2008c) ..................11

Figure 7. Locations of Beach Seine and Acoustic Node Sampling Sites during 2007 for the Tidal Freshwater Monitoring Study ...............................................................................................13

Figure 8. Site A, with Locations of Seine Hauls and Ancillary Points ..................................................14

Figure 9. Site B, with Locations of Seine Hauls, Ancillary Points, and the Acoustic Node ......................15

Figure 10. Site C, with Locations of Seine Hauls, Ancillary Points, and the Acoustic Node ....................16

Figure 11. Site D, with Locations of Seine Hauls and Ancillary Points ................................................17

Figure 12. Site N, with Locations of Seine Hauls and Ancillary Points ...............................................18

Figure 13. Site E, with Seine, Benchmark, Photo Point, and Acoustic Node Locations.............................19

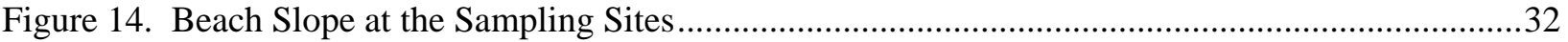


Figure 15. Beach Slope by Sampling Site. Sites A and B. ..................................................................33

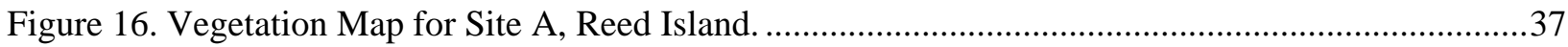

Figure 17. Vegetation Map for Site B, Chatham Island..........................................................................38

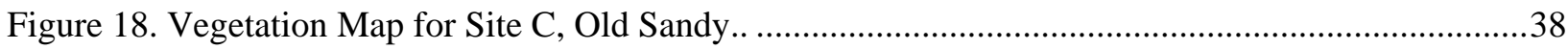

Figure 19 Vegetation Map for Site D, Sandy River. ................................................................................39

Figure 20. Vegetation map for Site N, Old Sandy ................................................................................39

Figure 21. Vegetation map for Site E, Gary Island. ............................................................................40

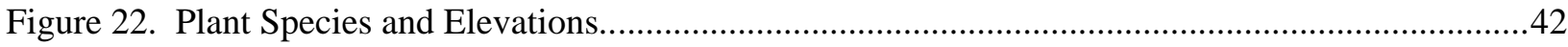

Figure 23. Total Combined Catch at all Sites throughout the 2007 Sampling Season.............................43

Figure 24. Temporal Distribution of the Average Catch for the Five Most Dominant Species.................46

Figure 25. Length Frequency Distribution for the Five Most Abundant Species Captured.......................47

Figure 26. Temporal Distribution of Average Catch of Chinook and Coho Salmon by Site......................48

Figure 27. Length Frequency Distribution by Site for Chinook Salmon ..............................................49

Figure 28. Length Frequency Distribution by Site for Coho Salmon. .....................................................50

Figure 29. Spatial and Temporal Distributions of Coho Salmon Size during 2007...............................50

Figure 30. Spatial and Temporal Distributions of Chinook Salmon Size during 2007............................51

Figure 31. Temperature Data from Ancillary Measurements during Seining Events. ...............................52

Figure 32. Dissolved Oxygen Data from Ancillary Measurements during Seining Events......................53

Figure 33. Seine Locations by Date for each Site ................................................................................54

Figure 34. Sums of Fractional Genetic Assignments of Individual Chinook Salmon by Collection Date.

Figure 35. Sums of Fractional Genetic Assignments of Individual Chinook Salmon by Sampling Site.

Figure 36. Spatial variance-to-mean density relationships using monthly beach seine data for various taxonomic groups; (a) all salmon, (b) all non-salmonid fish (c) non-fish, (d) bluegill, (e) banded killifish, (f) northern pikeminnow, (g) peamouth, and (h) threespine stickleback.

Figure 37. Sample size curves for estimating mean density at a site as a fraction of the coefficient of variation (CV) in densities encountered (1.25-2.0).

Figure 38. Run Timing Based on Total Valid Detections of Unique JSATS-Tagged Fish for All Locations Combined (Reed Island, Gary Island, Old Sandy Channel). .67

Figure 39. Pile Dikes Upstream of Chatham and Flag Islands (in background). .76 


\section{Tables}

Table 1. Sampling Dates during 2007 for the Tidal Freshwater Monitoring Study .20

Table 2. Genetic Stock Group and Baseline Populations .......................................................................25

Table 3. ANOVA Used to Estimate Variance Components....................................................................26

Table 4. Sample Periods, Servicing Dates, and Total Sample Days for Telemetry Receiving Nodes

Table 5. Sediment Grain Size Average Percent Composition. Highlighted cells indicate size classes with the highest percent composition for each site.

Table 6 Vegetation Species Found at Tidal Freshwater Monitoring Study Sites, with Common

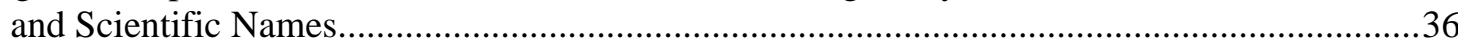

Table 7. Percent similarity using index between sites in the study.......................................................41

Table 8. Temporal Trends in Species Composition............................................................................44

Table 9. Spatial Trends in Species Composition ....................................................................................45

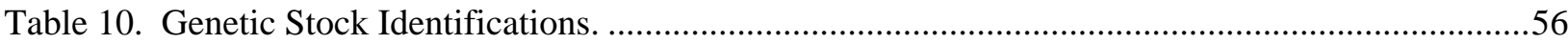

Table 11. Negative binomial [Eq. (4)] and log-normal [Eq. (5)] coefficients associated with spatial variance-to-mean relationships and coefficients of variation (CV) for replicate beach seines.

Table 12. Estimates of intra-class correlation for sites over time for various taxonomic groups. For sites B and N, all months of data were used

Table 13. Numbers of Valid Detections of JSATS-Tagged Chinook Salmon at the Nodes by Life History Type and Release Location (BON=Bonneville Dam and LGR=Lower Granite Dam).

Table 14. Residence Time (h) as Determined by Mean Duration between First and Last Valid Detections at a Given Sample Site.

Table 15. Migration Pathways for Yearling and Subyearling Chinook Salmon Tagged with JSATS Transmitters and Having Valid Detections at Nodes in the Study Area.. 


\subsection{Introduction}

This document is the 2007 Annual Report for the study titled "Ecology of Juvenile Salmonids in Shallow Tidal Freshwater Habitats in the Vicinity of the Sandy River Delta in the Lower Columbia River." Hereafter, we refer to this research as the Tidal Freshwater Monitoring (TFM) Study. The study is part of the research, monitoring, and evaluation effort developed by the Action Agencies (Bonneville Power Administration, U.S. Army Corps of Engineers, U.S. Bureau of Reclamation) in response to obligations arising from the Endangered Species Act (ESA) as a result of operation of the Federal Columbia River Power System (FCRPS). The study is performed under the auspices of the Northwest Power and Conservation Council’s Columbia Basin Fish and Wildlife Program.

\subsection{Goal and Objectives}

The goal of the 2007-2009 Tidal Freshwater Monitoring Study is to answer the following questions:

In what types of habitats within the tidal freshwater area of the lower Columbia River and estuary (LCRE; Figure 1) are yearling and subyearling salmonids found, when are they present, and under what environmental conditions? ${ }^{1}$

What is the ecological importance $e^{2}$ of shallow $(0-5 \mathrm{~m})$ tidal freshwater habitats to the recovery of Upper Columbia River spring Chinook salmon and steelhead and Snake River fall Chinook salmon?

Research in 2007 focused mainly on the first question, with fish stock identification data providing some indication of Chinook salmon presence at the variety of habitat types sampled. The objectives and sub-objectives for the 2007 study were as follows:

1. Habitat and Fish Community Characteristics - Provide basic data on habitat and fish community characteristics for yearling and subyearling salmonids at selected sites in the tidal freshwater reach in the vicinity of the Sandy River delta.

1a. Characterize vegetation assemblage percent cover, conventional water quality, substrate composition, and beach slope at each of six sampling sites in various tidal freshwater habitat types.

${ }^{1}$ This question was recommended by the Independent Scientific Review Panel (ISRP 2005).

${ }^{2}$ Ecological importance refers to the effects that habitat structures have on ecosystem processes and functions (Thom 1987; Thom 2000). In the present case, ecological importance is defined as how the substrate, water velocity regime, bathymetry, vegetation, prey resources, etc. in the LCRE influence juvenile salmon production, growth, and survival. Thom et al. (2004) provide a conceptual ecosystem model that outlines these relationships. 
1b. Determine fish community characteristics, including species composition, abundance, and temporal and spatial distributions.

1c. Estimate the stock of origin for the yearling and subyearling Chinook salmon captured at the sampling sites.

1d. Statistically assess the relationship between salmonid abundance and habitat parameters, including ancillary variables such as temperature and river stage.

2. Acoustic Telemetry Monitoring - Assess feasibility of applying Juvenile Salmon Acoustic Telemetry System (JSATS) technology to determine migration characteristics from upriver of Bonneville Dam through the study area in the vicinity of the Sandy River delta/Washougal River confluence.

2a. Determine species composition, release locations, and distributions of JSATS-tagged fish.

2b. Estimate run timing, residence times, and migration pathways for these fish.

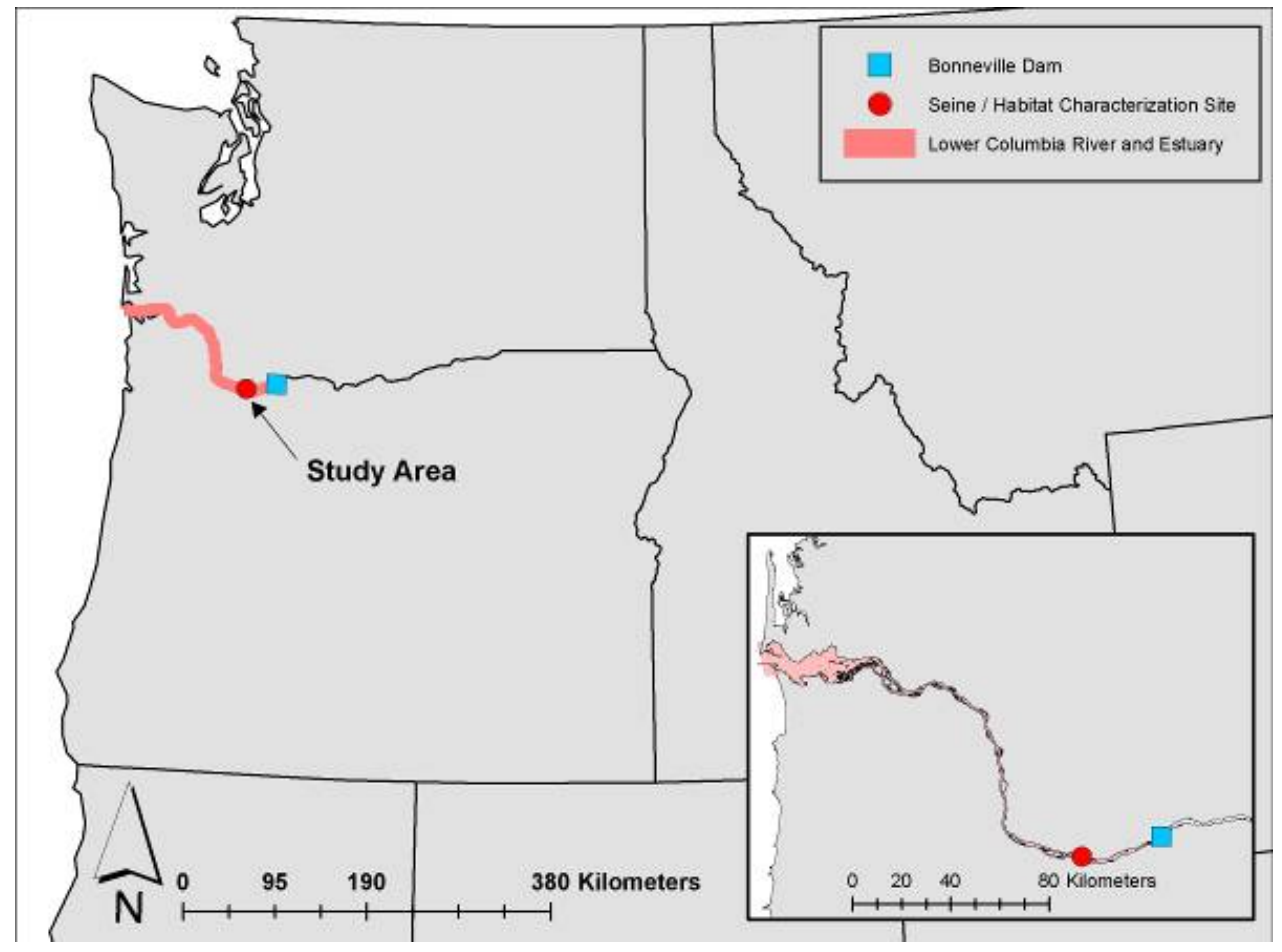

Figure 1. Map of Lower Columbia River and Estuary. The tidal freshwater portion is at approximately rkm 56-234 and our study area is at rkm 193-201.

These objectives and sub-objectives address basic elements of research, monitoring, and evaluation (RME), namely status and trends monitoring, action effectiveness research, and critical uncertainties research. Overall, the work on Habitat and Fish Community Characteristics can be applied to status and trends because it is routine, periodic monitoring of juvenile salmonid abundance. In addition, the study pertains to critical uncertainties because the research concerns ESA listed yearling and subyearling salmonids in tidal freshwater, an under-studied topic (Williams 2007). 
Additionally, both objectives serve the purpose of baseline research on action effectiveness of the potential tidal rechannelization project in the Sandy River delta (see below). The U.S. Forest Service (USFS), in partnership with Bonneville Power Administration (BPA) and the U.S. Army Corps of Engineers (USACE), is currently pursuing reconnection of the east (relict) Sandy River channel with the current channel to improve fish and wildlife habitat in the Sandy River delta. To reconnect the channel, the dam, built in the 1930s, would be partially removed and a bridge would be built for access to Sundial Island and the BPA power transmission lines in the Sandy River delta area. The location of our sites in this reach allows for collection of baseline data both at the site and near the site prior to the potential restoration.

\subsection{Background}

Shallow water habitats $(0-5 \mathrm{~m})$ in the tidal freshwater portion of the LCRE (Figure 1 ) are thought to be of importance for the growth and survival of both stream-type (yearling) and ocean-type (subyearling) life histories of salmon (Fresh et al. 2005). Scientific knowledge specifically addressing this hypothesis, however, is sparse and current monitoring efforts are fragmented (Johnson et al. 2008). This situation, although not prioritized explicitly, is identified in both the Mainstem Lower Columbia River and Columbia River Estuary Subbasin Plan (LCREP and LCFRB 2004), which includes ocean-type fall Chinook (Oncorhynchus tshawytscha) and chum (O. keta) salmon among its focal species, and the Implementation Plan for the Updated Proposed Action (USACE et al. 2005), which includes specific reference to endangered Snake River fall Chinook salmon in the LCRE. Currently, the Action Agencies and the National Marine Fisheries Service (NMFS) are collaborating with the states and tribes, and are in negotiations over the 2008 biological opinion on FCRPS operations. Previously, the parties identified gaps between current and predicted population status of listed species; the biggest gaps include Upper Columbia River spring Chinook salmon and summer steelhead (O. mykiss). The Independent Scientific Review Panel (ISRP) and the Independent Scientific Advisory Board (ISAB) have advocated RME in the tidal freshwater area of the Columbia River (Bisson et al. 2000; ISRP 2004). As the ISRP stated in their review of FY07-09 proposals, "The Council should encourage innovative ecosystem-based research and monitoring in the estuary...”

The subyearling migrant, or ocean-type, life history pattern (after Healey 1991) is characterized by downstream migration within the first days or months after emergence from natal stream gravels and subsequent residence in riverine and estuarine shallow water habitats. Subyearling salmon have been found in shallow water or nearshore habitats of the Fraser River estuary (Levy and Northcote 1982) and the Nanaimo estuary (Healey 1978) in British Columbia, the nearshore waters of Puget Sound (Brennan et al. 2004; Beamer et al. 2005), the Sacramento-San Joaquin estuary (Kjelson et al. 1982), the Sixes and Coquille estuaries (Reimers et al. 1979), the Salmon River estuary (Bottom et al. 2005a), and Yaquina Bay (Meyers and Horton 1982) on the Oregon coast. Although specific fish/habitat linkages are not always evident, especially in highly migratory species such as Pacific salmon (Simenstad and Cordell 2000), it is likely that salmon with ocean-type life history patterns depend on shallow, estuarine habitats for rearing and refuge (Fresh et al. 2005). 
Alternatively, the yearling life history pattern is characterized by downstream migration after a period of 12 or more months spent rearing in the fish's natal stream system. Yearling fish typically migrate downriver faster than subyearling fish (Dawley et al. 1986). Yearling fish, however, may linger in shallow water habitats to feed for a period of time, avoiding strong currents in the main channel of the LCRE. Thus, it is prudent to assume the LCRE serves a greater role than a simple migration conduit for yearling salmonids. Our study is intended to address this uncertainty.

Basic habitat requirements of juvenile salmonids include provision of food, shelter, space, and suitable environmental conditions (Chapman 1966; Bjornn and Reiser 1991). Habitat parameters of greatest importance to juvenile salmonids are water temperature, depth, velocity, and cover (Healey 1980; Fausch 1993; Quinn 2005). Like all organisms, juvenile salmonids must maximize energy intake while minimizing energy expenditure, and must balance gains from feeding in profitable habitats with risk of predation (Fausch 1984; Harvey 1991). Parameters regulating this balance change with body size and therefore energetic demands, ability to detect and avoid predators, and the nature of suitable environmental conditions. Juvenile salmonids undergo an ontogenetic habitat shift into deeper, faster water (e.g. Healey 1980; Werner 1984) that occurs at specific size thresholds rather than gradually (Simenstad et al. 1980). Documentation of habitat use by subyearling and yearling upriver fall Chinook salmon in the tidal freshwater portion of the lower Columbia River is limited (Fresh et al. 2005) and it is also unknown how local populations of Chinook and coho (O. kisutch) use off-channel areas.

Juvenile fall Chinook salmon generally prefer faster water and smaller substrates, and are less associated than other salmonids with cover and backwater habitats such as ponds and sloughs (Chapman and Bjornn 1969; Taylor 1988; Murphy et al. 1989). Bottom et al. (1984, cited in Fresh et al. 2005) found that yearling Chinook salmon in intertidal habitats of the Columbia River spent less time in shallow habitats and more time in deeper channel habitats than did subyearlings. Because fall Chinook salmon display a wide range of life history strategies (Healey 1991) and both yearling and sub-yearling arrivals in the estuary occur potentially year-round (Connor et al. 2005), patterns of habitat use in the freshwater tidal estuary are certain to be complex, and consequently, much remains unknown.

Juvenile growth and survival in estuarine habitats is of critical importance to population growth and stability and therefore recovery of the species (Fresh et al. 2005). Availability of diverse shallow-water habitats, especially very shallow peripheral habitats, may be a limiting factor to the production and diversity of salmonids such as upriver fall Chinook salmon (Fresh et al. 2005; Quinn 2005). However, extensive tidal freshwater reaches such as in the Columbia River ( $\sim 180 \mathrm{~km}$ in length) are rare in rivers, thus little information exists on the ecology of these ecosystems. For example, of 26 estuarine systems evaluated in Europe, only seven had sizeable tidal freshwater habitats, and of those, none were over $40 \mathrm{~km}$ in length (Pihl et al. 2002).

Downstream of Jones Beach (rkm 75) in the LCRE, the migration characteristics of juvenile salmon have been studied extensively (Dawley et al. 1986; Ledgerwood et al. 1991). Researchers have used nets, seines, traps, and trawls to examine migration timing, spatial distribution, abundance, 
relative survival, and feeding habits for various populations of salmon. Important research efforts have been supported by the U.S. Bureau of Fisheries (Rich 1920), the Fish Commission of Oregon in 1963 (Reimers and Loeffel 1967), the National Marine Fisheries Service in 1966-1972 (Craddock et al. 1976; Durkin 1982; Dawley et al. 1986), the Northwest Regional Council and the Bonneville Power Administration in 1977-1983 (Dawley et al. 1986; Kirn et al. 1986; Ledgerwood et al. 1991), the Columbia River Estuary Data Development Program in 1978-1984 (McCabe et al. 1983; Bottom et al. 1984; Small 1990), the Corps of Engineers Anadromous Fish Evaluation Program in 1995present (Ledgerwood et al. 2003; Roegner et al. 2004; Schreck et al. 2004), and the Northwest Power and Conservation Council's Fish and Wildlife Program in 2001-present (Weitkamp 1994; Burke 2004; Bottom et al. 2005b; Fresh et al. 2005). Significant findings on yearling and subyearling salmon in the LCRE from these studies, with relevance to the research undertake herein, include:

- Sampling sites included shallow water habitats in marine, estuarine, and freshwater areas mostly from the mouth to Jones Beach (rkm 75). The tidal freshwater reach from rkm 75 to Bonneville Dam (rkm 234) has been little studied.

- Compared to historical records, diversity of life history types in the LCRE have diminished (Burke 2004; Bottom et al. 2005b).

- The abundance of wild salmon in the LCRE is much lower than historically; the opposite is true for hatchery salmon (Bottom et al. 2005b).

- Subyearling salmon from watersheds below Bonneville Dam are more abundant in shallow water habitats than subyearlings from upriver (Roegner et al. 2004).

- Peak abundance in shallow water habitats (in the vicinity of Jones Beach, rkm 75) is in April through August for subyearling Chinook salmon, April through mid-June for yearling Chinook salmon, and March through May for subyearling chum salmon (Dawley et al. 1986).

- Subyearling salmon may reside in the estuarine waters for extended periods of time (weeks to months; e.g., Rich 1920), and smaller individuals using shallow water habitats to feed spend more time in the LCRE than larger fish (Dawley et al. 1986). Some juvenile salmon overwinter in the LCRE (Dawley et al. 1986).

- Subyearlings sampled in shallow water nearshore are typically smaller than those from midriver (Bottom et al. 1984; Dawley et al. 1986; McCabe et al. 1986). Fish at tidal freshwater sites are on average smaller than those at estuarine and marine sites (Roegner et al. 2004).

- Subyearling fish eat Corophium spp. and terrestrial insects in shallow water habitats (Kirn et al. 1986; McCabe et al. 1986; Roegner et al. 2004). Average fork length (FL) tends to increase from spring to summer (Dawley et al. 1986; Roegner et al. 2004).

- Juvenile salmon migration characteristics in the LCRE are influenced by upriver forces, such as hydropower operations and hatchery practices (Weitkamp 1994; Bottom et al. 2005b).

The Upper Columbia River Basin spring Chinook salmon and summer steelhead were listed as endangered in 1996 and 1999, respectively. As yearlings, these fish are thought to migrate downstream through the hydrosystem, generally during April through June, and reach the LCRE 
relatively quickly. Based on catches of marked wild and hatchery yearling outmigrants at Jones Beach ( $r k m ~ 75)$, in the marine mixing zone ( $r k m ~ 7-9)$, and near ocean areas (24 km seaward from the river mouth), almost all individuals used the estuary as a migration corridor and moved rapidly into the ocean (Dawley et al. 1986).

Snake River fall Chinook salmon were listed as threatened under the Endangered Species Act in 1992 (NOAA 2004). This ESU (Evolutionarily Significant Unit, Waples 1991) consists of fall Chinook salmon spawning populations in the Snake, Tucannon, Clearwater, Salmon, Imnaha and Grande Ronde rivers. Subyearling fish, including Snake River fall Chinook salmon juveniles, generally migrate downstream through the hydrosystem from June through September. Snake River fall Chinook salmon were thought to primarily exhibit an ocean-type life history in which adults spawn in the fall, fry emerge the following spring, and juvenile fish emigrate seaward during late spring and summer to enter the ocean as subyearlings (Connor et al. 2002). However, Connor et al. (2005) recently described an alternative life history for juvenile Snake River fall Chinook salmon which they named "reservoir-type" life history. Fish that adopt the "reservoir-type" life history delay their subyearling ocean entry, spend the winter in fresh water, and resume migration to the ocean the following year to enter the ocean as yearlings. Freshwater over-wintering areas could include the tidal freshwater portion of the LCRE (Connor et al. 2005). Fresh et al. (2005, p. xiii) concluded, “...upriver ESUs (e.g., Snake River fall Chinook salmon) will be more dependent on the tidally influenced shallow freshwater habitats between Bonneville Dam (their point of entry to the Columbia River estuarine system) and RM 40 [rkm 64].” Over-wintering and extended residence in estuarine habitats has been documented for fall Chinook salmon in the Columbia River and from other watersheds (Reimers and Loeffel 1967; Reimers 1968; Reimers 1973). As such, it is possible that a portion of Snake River fall Chinook salmon over-winter in the Columbia River estuary including the tidal freshwater section within our study area.

In the LCRE, the substantial loss (>75\%) of shallow water habitats through diking, filling, dredging and development is suggested as one important factor contributing to the decline of salmonids in the system (Thomas 1983; Simenstad et al. 1992). Fresh et al. (2005) suggested that restoration of shallow water habitat could result in enhanced performance (e.g. foraging success, growth), and thus, increased survival of juvenile salmonids. Currently, there are limited data on the use of habitat in upstream reaches of the LCRE by juvenile salmonids that could contribute to an understanding of how restoration actions might enhance salmonid performance. Therefore, this study is focused on supplying fundamental data on this topic both to enhance general understanding of how juvenile salmonids use LCRE tidal freshwater habitat and to improve prioritization of restoration efforts. Restoration is expensive and results can be uncertain in terms of functional performance and overall benefits to resources and the ecosystem (Thom 2000). Our study will contribute directly to reducing uncertainty about yearling and subyearling salmonid presence in tidal freshwater habitats and, ultimately, the beneficial attributes of these habitats, thereby improving the likelihood of success for ecosystem-based restoration projects targeted at benefiting salmon. 


\subsection{Study Area Characteristics}

Our study area lies within the upper tidal freshwater portion of the Columbia River in the vicinity of the Sandy and Washougal Rivers, extending from rkm 193 to 201. This section is within Reach G, as described by the Lower Columbia River and Estuary Ecosystem Classification being developed for the Lower Columbia River Estuary Partnership (LCREP) by the University of Washington and the U.S. Geological Survey (Figure 2). Within this reach there are floodplain, island, shallows, and river confluence habitats. This reach was selected because of the diversity of habitats, relatively little fish work has been conducted in this portion of the tidal freshwater reach of the river, and there is a potential habitat restoration action in the Sandy River delta for which baseline fish data could be informative.

Kukulka and Jay (2003) distinguish the section of river upstream of rkm 140 from the rest of the tidal-fluvial reach (rkm 50-234) as more influenced by power-peaking from FCRPS than from tidal influences. Observational data from a water surface elevation gauge installed at McGuire Island (rkm 190; downstream of the Sandy and Washougal rivers) showed tidal signals and power-peaking signals, which were largely dependent upon time of year and water level (K. Sobocinski, unpublished data). While tidal influence extends to Bonneville Dam, the low tidal magnitude in our study reach (mean range is approximately $0.4 \mathrm{~m}$ at Vancouver, WA, rkm 175), may mean that fluctuations from dam-related activities and regional weather patterns exert a greater impact than fluctuation in tidal elevation on water conditions within the study region.

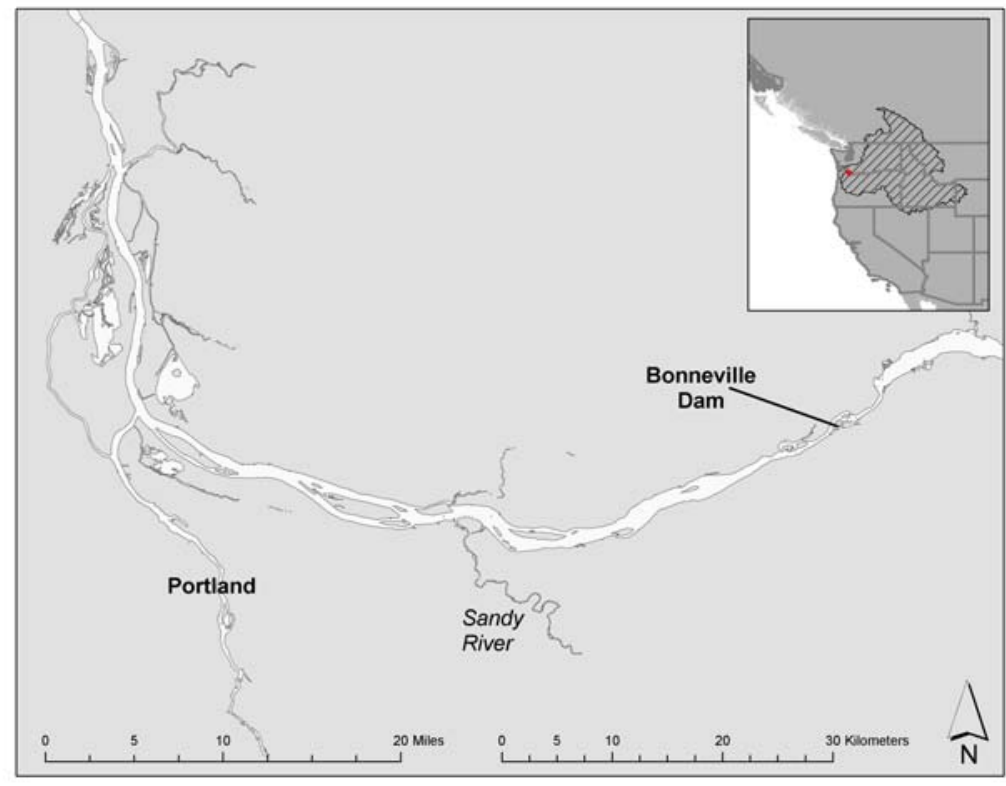

Figure 2. Focal Reach in the LCRE, in the Vicinity of the Sandy River 


\subsection{River Discharge and Temperature}

During our sampling period (June-December 2007), water levels in the Columbia River were similar to the 10-year average (1998-2007, Figure 3). Outflow was considerably higher than average in the early spring months and returned to average by June. The lowest levels observed during our study period occurred in October and November, which is consistent with other years (Figure 3).

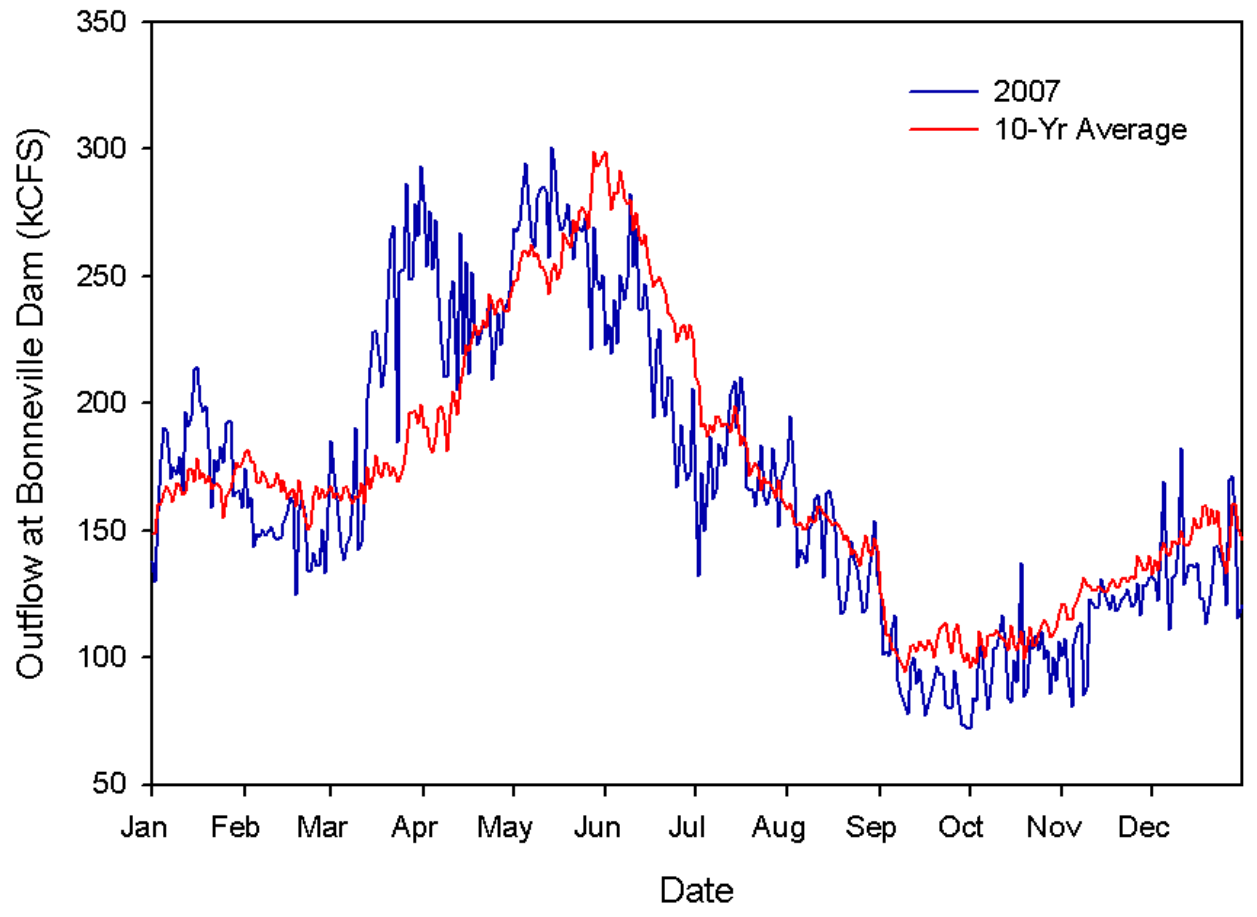

Figure 3. Outflow (kcfs) at Bonneville Dam, 2007

Because our study sites were located approximately $35 \mathrm{~km}$ downstream from Bonneville Dam, we also collected gauge height data from a USGS stream-height gauge at Vancouver, Washington. The streamflow pattern at this gauge (Figure 4c, height being a surrogate for volume) follows a temporal trend similar to that observed at Bonneville Dam (Figure 4b). While localized conditions can influence small-scale changes in flow patterns, such as eddies, shoals, or areas of increased current, larger-scale patterns such as snow melt and seasonal run-off influence temporal trends to a greater extent in this portion of the river.

We also compared temperature (scroll case temperature at Bonneville Dam) between 2007 and the 10-year average (1998-2007) and found peak temperatures to be slightly above average, though overall the pattern was similar to average. Temporal trends are characterized by a peak in water temperature during the summer months, coinciding with high air temperatures and a decline in outflow (Figure 4a and 4b). 


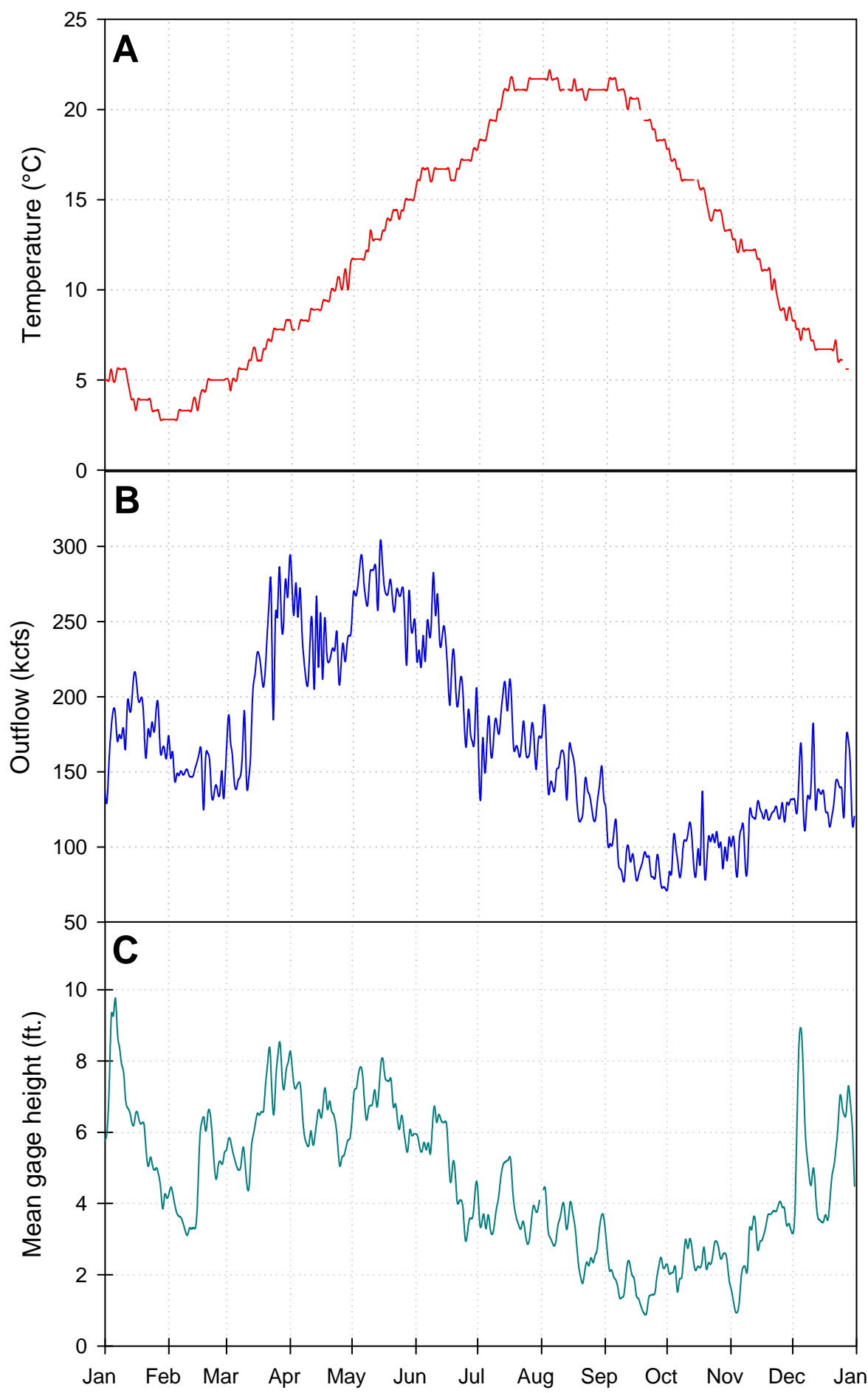

Figure 4. A) Scroll Case river temperature measured at Bonneville Dam, 2007. B) Columbia River outflow measured at Bonneville Dam, 2007 (Columbia River DART 2008a). C) Columbia River gage height measured at Vancouver, WA (USGS 2008). 


\subsection{Emigration Characteristics}

\subsubsection{Species Composition and Run Timing}

The smolt index calculated at Bonneville Dam as part of the regional Smolt Monitoring Program incorporates both juvenile salmonid sample counts and project discharge. The index uses body morphology and run timing to determine the age class of Chinook salmon, but cannot distinguish wild versus hatchery-origin fish because not all hatchery fish are marked or fin-clipped. Four major peaks in the subyearling Chinook migration at Bonneville occurred in 2007; early March, mid-April, early May, and early July. Run timing for yearling Chinook and coho salmon and steelhead (O. mykiss) at Bonneville peaked during May (Figure 5; DART 2008b). The peaks for subyearling Chinook salmon correspond to hatchery releases upstream of Bonneville Dam.

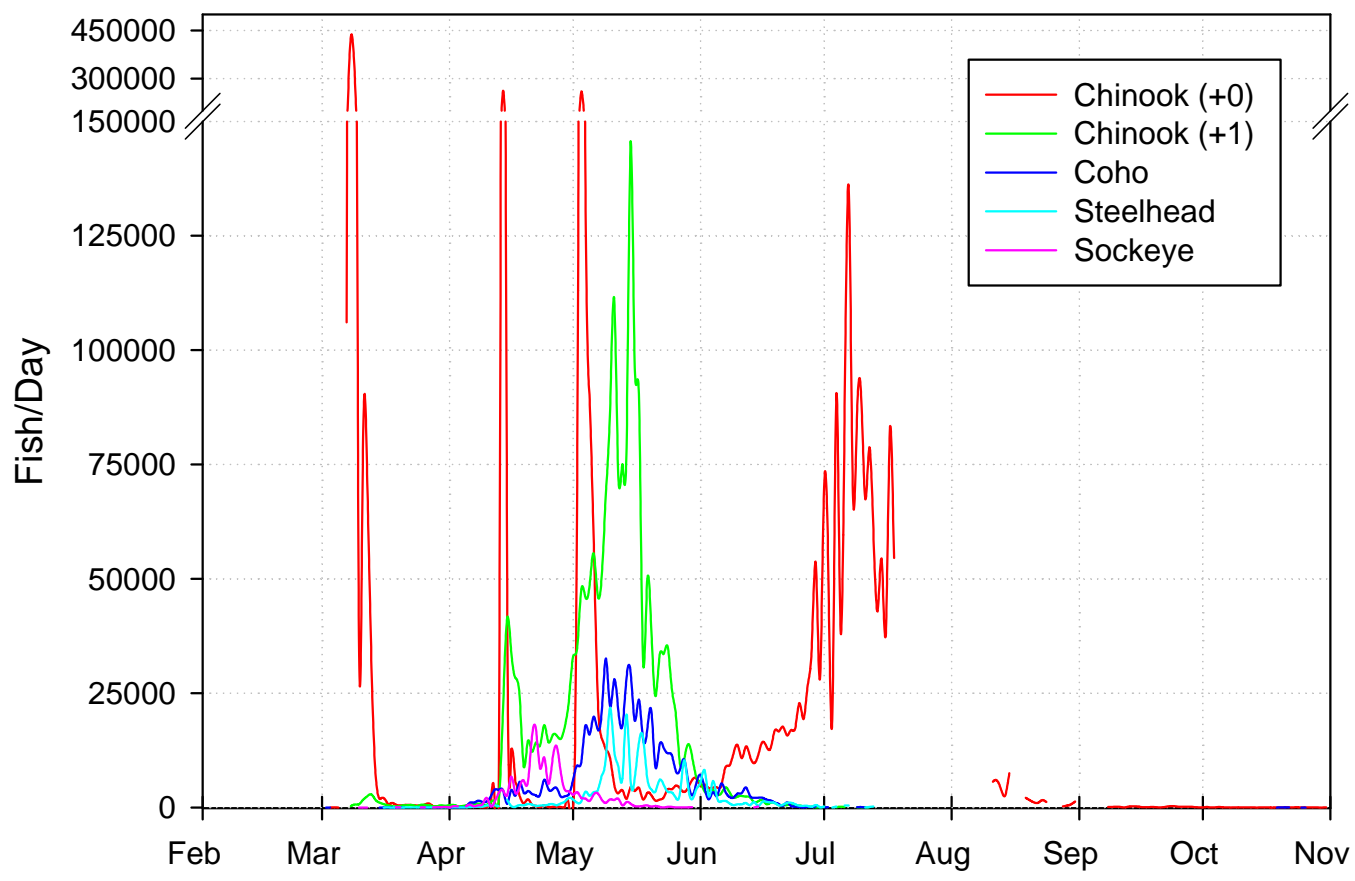

Figure 5. 2007 Bonneville Dam Smolt Monitoring Index (DART 2008b)

\subsubsection{Nearby Hatchery Fish Releases}

Near our study area, the Sandy River and the Washougal River are source tributaries for several stocks of hatchery origin salmon. Hatchery releases of juvenile salmonids from both river systems occur throughout the spring months from March through June. Within these two watersheds the only hatchery release to coincide with our 2007 sampling period was that of 4.2 million subyearling Chinook salmon from Washougal River in late June (Figure 6; DART 2008c). 


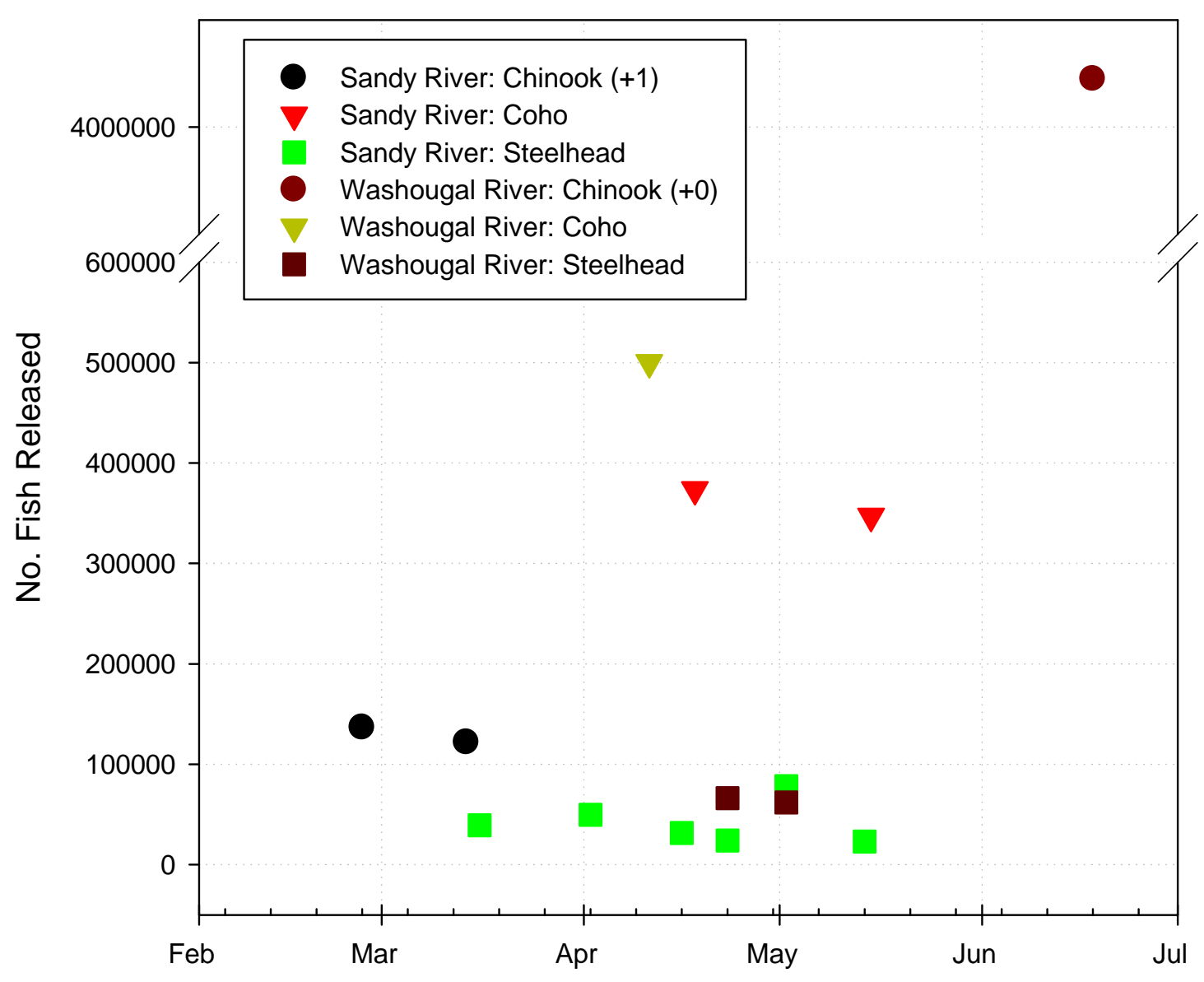

Figure 6. 2007 Salmon Hatchery Releases in the Vicinity of the Study Area (DART 2008c) 


\subsection{Methods}

This section contains the sampling design, data collection, processing, and analysis methods for habitat and fish community characteristics, and acoustic telemetry methods.

\subsection{Sampling Design}

\subsubsection{Sites}

To select sites for the study, PNNL and ODFW researchers conducted a preliminary field trip on April 18, 2007. We evaluated sites for feasibility of seine sampling, including boat access, net deployment and retrieval, and fish processing. We also examined physical characteristics and representativeness (island, off-channel, etc.) for the purposes of research regarding juvenile salmon usage. We selected an initial set of sites (A, B, C, and D) during this inaugural field trip (Figure 7). Specific seine haul locations were determined during the first sampling trip in June 2007. Also, in June 2007 Site N was added to allow for pre-restoration monitoring related to the proposed restoration of the old Sandy River channel (Figure 7).

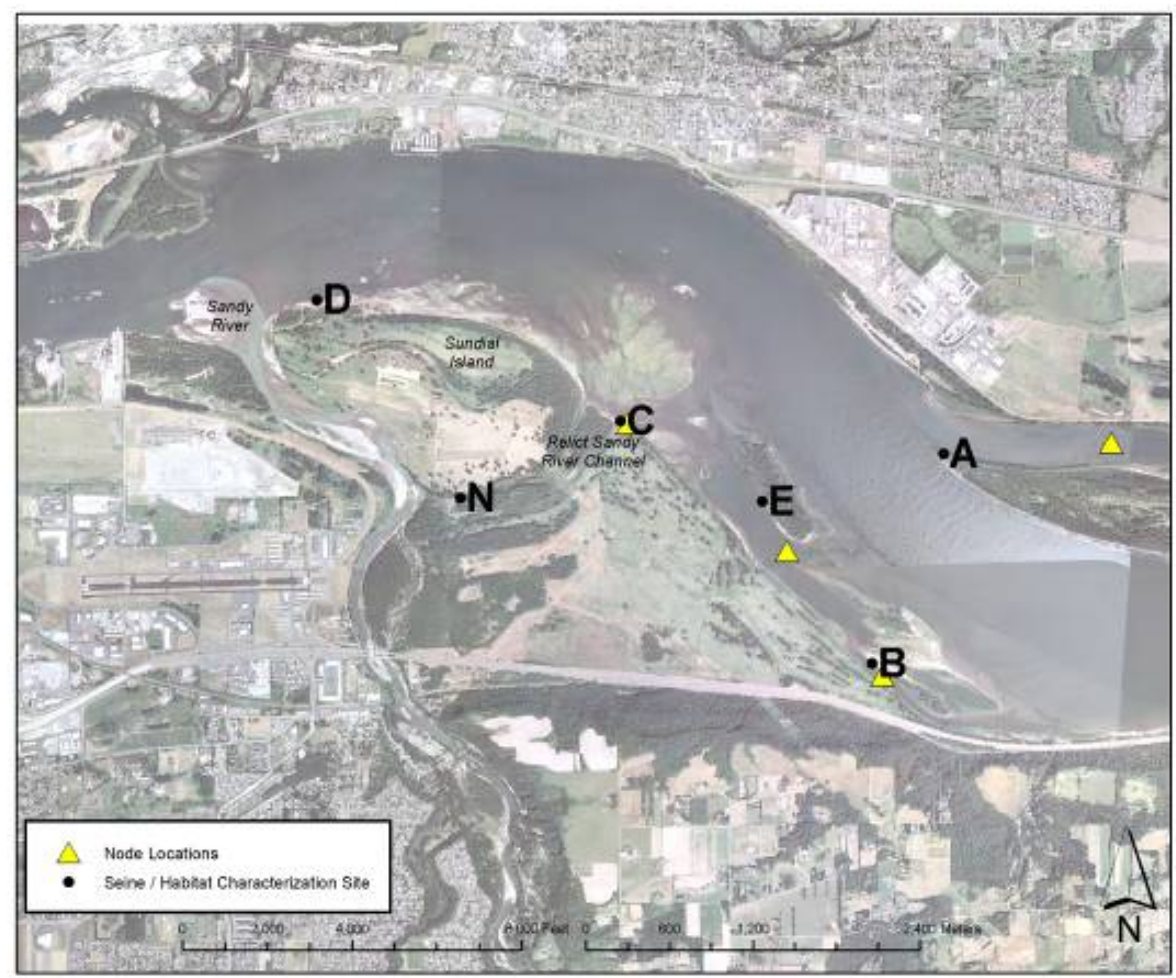

Figure 7. Locations of Beach Seine and Acoustic Node Sampling Sites during 2007 for the Tidal Freshwater Monitoring Study 
Acoustic node locations were selected in collaboration with researchers at PNNL's North Bonneville office; locations that would be suitable for deploying the nodes, as well as informative to the research project were selected. Typically, the nodes are installed in water deeper than we were targeting for this study, and as such, modifications to the rigging for the nodes and anchors had to be made. Node positions are shown in Figure 7.

Site A, is on the north side of Reed Island (Figures 7 and 8) at the downstream end. There is fringing wetland along this side of the island, rising to a berm with cottonwoods and other riparian vegetation. At high water, much of the emergent vegetation is submerged and at low water the depth at the outer edge of the beach seine is about $0.5 \mathrm{~m}$, making it of moderate depth relative to the rest of the sampling sites. Reed Island is maintained as a park by the State of Washington. The sampling site was not sampled during the first three trips due to a delay in obtaining permits.

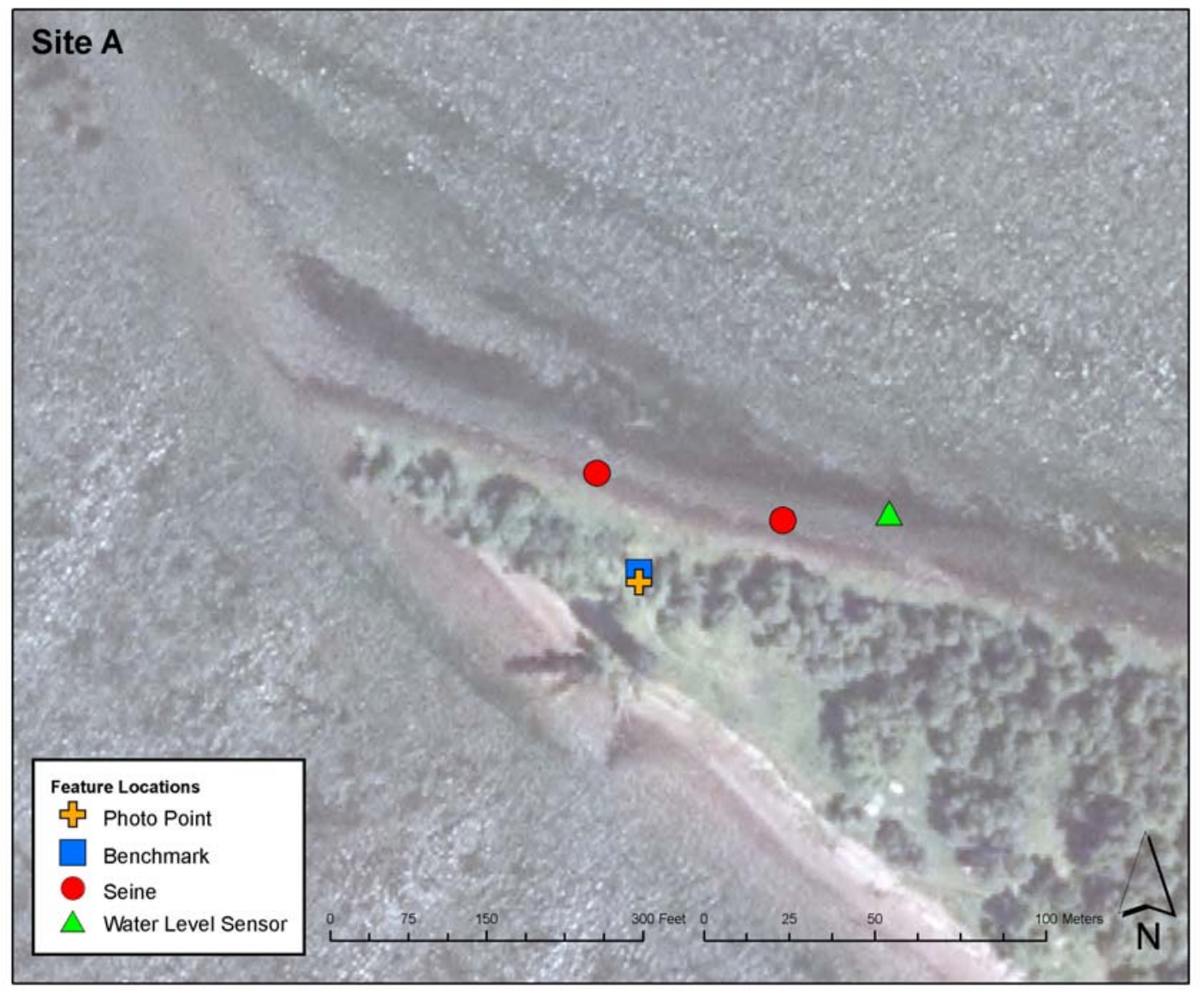

Figure 8. Site A, with Locations of Seine Hauls and Ancillary Points 
Site B is on the southwest side of Chatham Island, on the Oregon side of the river (Figures 7 and 9). Chatham Island and Flag Island form a low-elevation island complex, with the two islands separated only at high water. Along the beach face that we sample, there is very little vegetation directly on the beach, but extensive submerged aquatic vegetation (SAV) in the summer months. Downstream and upstream from the sampling site are areas of submerged aquatic vegetation. There are few large trees on Chatham Island, but numerous moderately sized (2-4 m) willows (Salix spp.). The depth at Chatham Island is greater than at the other sites (with the exception of Site E, which is similar in profile), with a steep drop off present at all water levels. At low water, the maximum depth at the outer edge of the beach seine is approximately $1.5 \mathrm{~m}$. An acoustic node was deployed in the channel between Chatham Island and the Oregon shore, in the vicinity of this site.

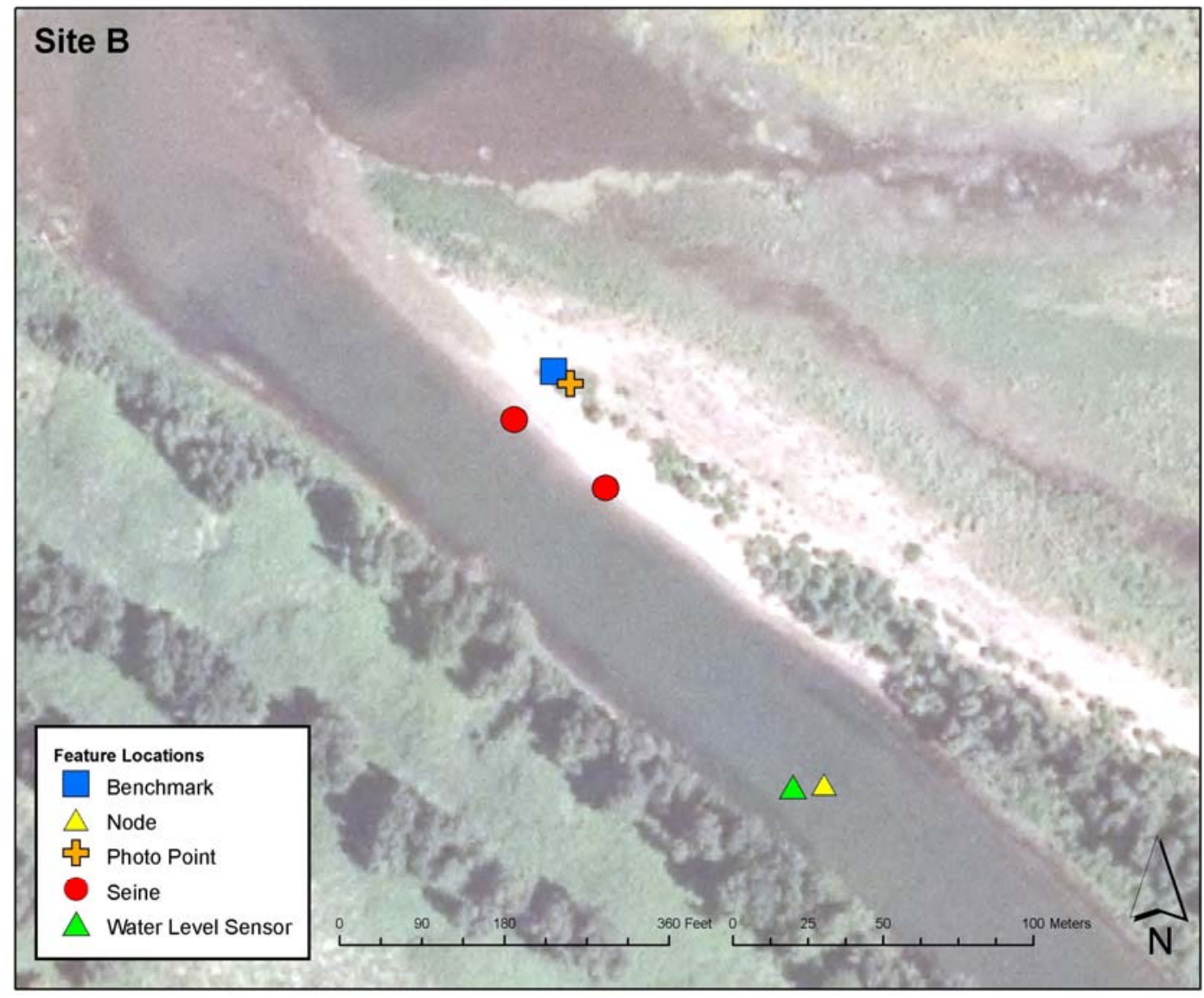

Figure 9. Site B, with Locations of Seine Hauls, Ancillary Points, and the Acoustic Node 
Site C is located at the mouth of the relict Sandy River channel on the upstream edge of Sundial Island, approximately 2.5-km upstream from the current channel mouth (Figures 7 and 10). We sample on the downstream side of the old channel, in an area with extensive flats at low water. This area of shallows eventually leads to higher elevation island-like habitats towards the mainstem of the river. During low flows, the water at the site is extremely shallow $(0.1 \mathrm{~m})$, if present at all. At higher water, there is a relatively steep slope from an area of extensive riparian vegetation. Just upstream from where the fish sampling occurs there is a fairly broad area of emergent marsh vegetation. The relict channel is on the upstream side of this and is only about $0.2 \mathrm{~m}$ in depth during the summer months, with very slow or negligible water movement. An acoustic node was placed in a deep pocket at the mouth of the relict channel at this site.

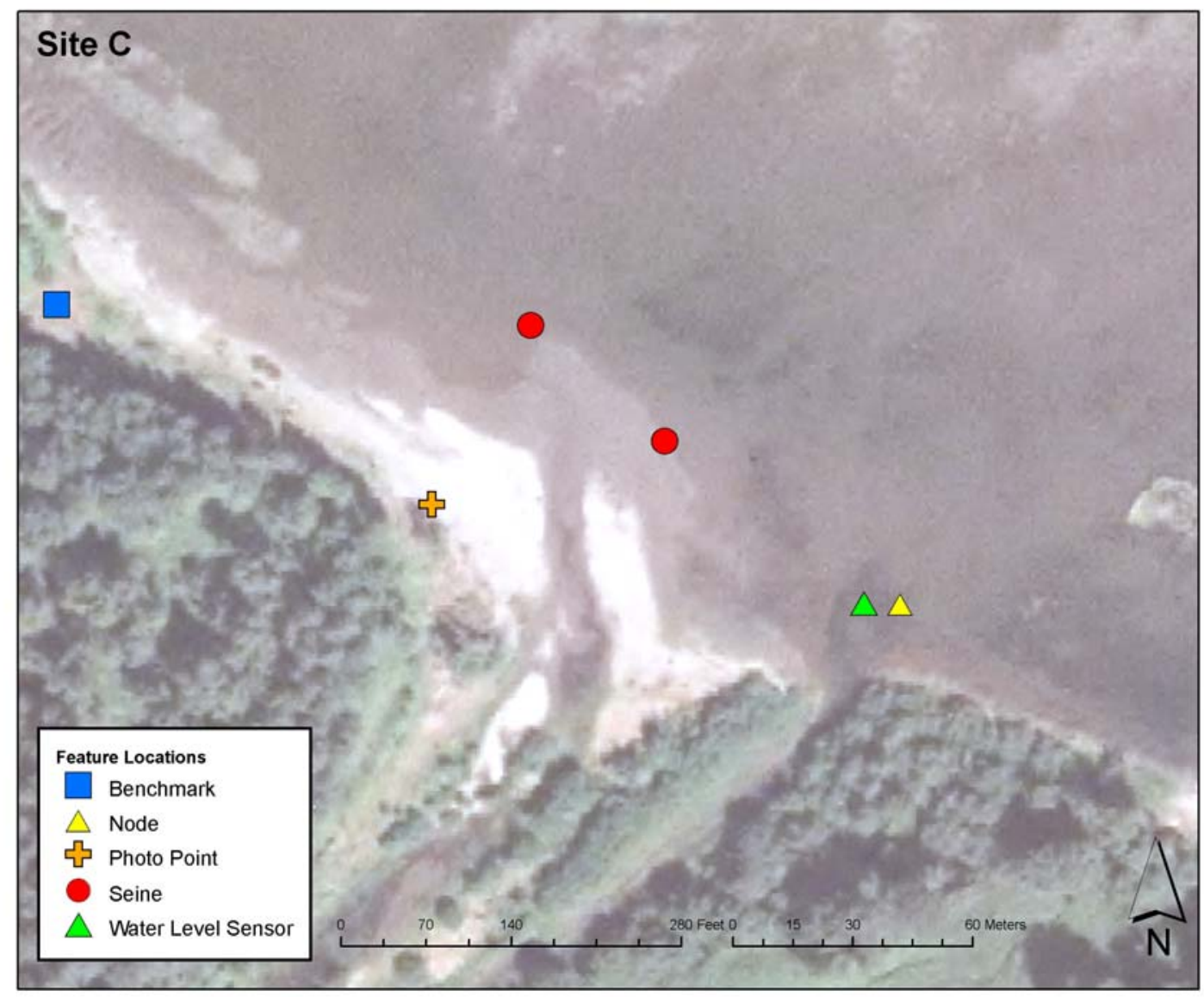

Figure 10. Site C, with Locations of Seine Hauls, Ancillary Points, and the Acoustic Node 
Site D is located just upstream from the mouth of the current Sandy River channel (Figures 7 and 11). This site is similar in profile to Site $C$, but without the island areas near the site. At low water there is a long area of shallows ( $<1 \mathrm{~m}$ in depth) between the main river channel and the water's edge on the bank of Sundial Island. Water depth at the outer edge of the beach seine is approximately 0.2 $\mathrm{m}$ in the late summer, but over $1 \mathrm{~m}$ at high water. While the beach itself is free of vegetation, riparian vegetation (cottonwoods and willows) occurs above ordinary high water. Upstream from the site is an area with a lower slope to the riparian berm which contains emergent vegetation. Both Sites $\mathrm{C}$ and $\mathrm{D}$ are devoid of thick submerged aquatic vegetation.

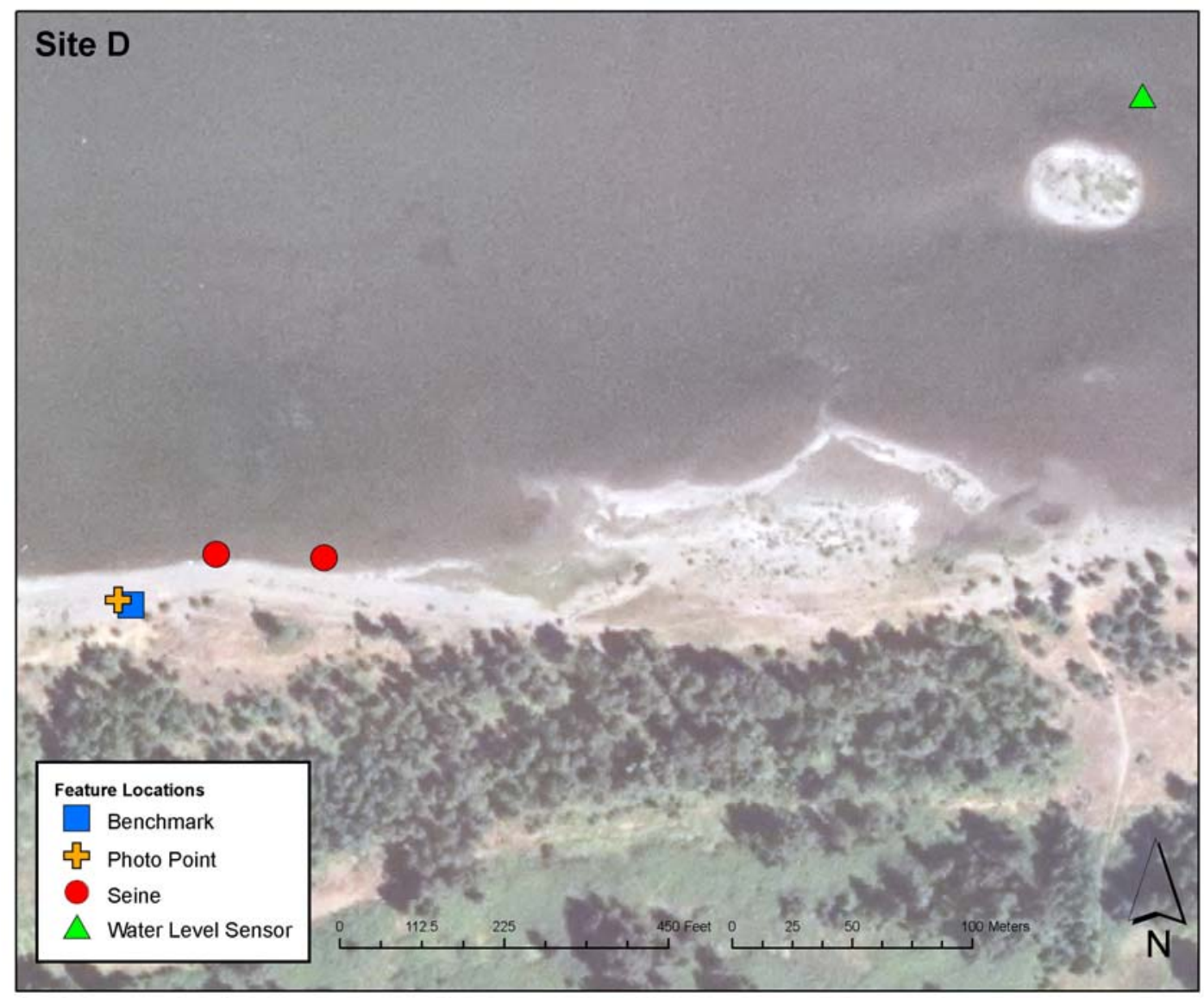

Figure 11. Site D, with Locations of Seine Hauls and Ancillary Points 
Site $\mathrm{N}$ was added after the initial site selection field trip to allow for pre-restoration monitoring related to the proposed restoration of the old Sandy River channel. This site is located approximately $100 \mathrm{~m}$ east of the existing cobble blockage/dam connecting Sundial Island to the main landmass near Troutdale, OR (Figures 7 and 12). At low water, this site is disconnected from the Columbia River; however, during flood events, either from the Sandy River or from the Columbia River, high water tops the cobble blockage and reconnects the Columbia River with the Sandy River at this location. With extensive submerged aquatic vegetation and moderately deep but stagnant water ( $>1 \mathrm{~m}$ in late summer), this site is markedly different in physical characteristics from the others.

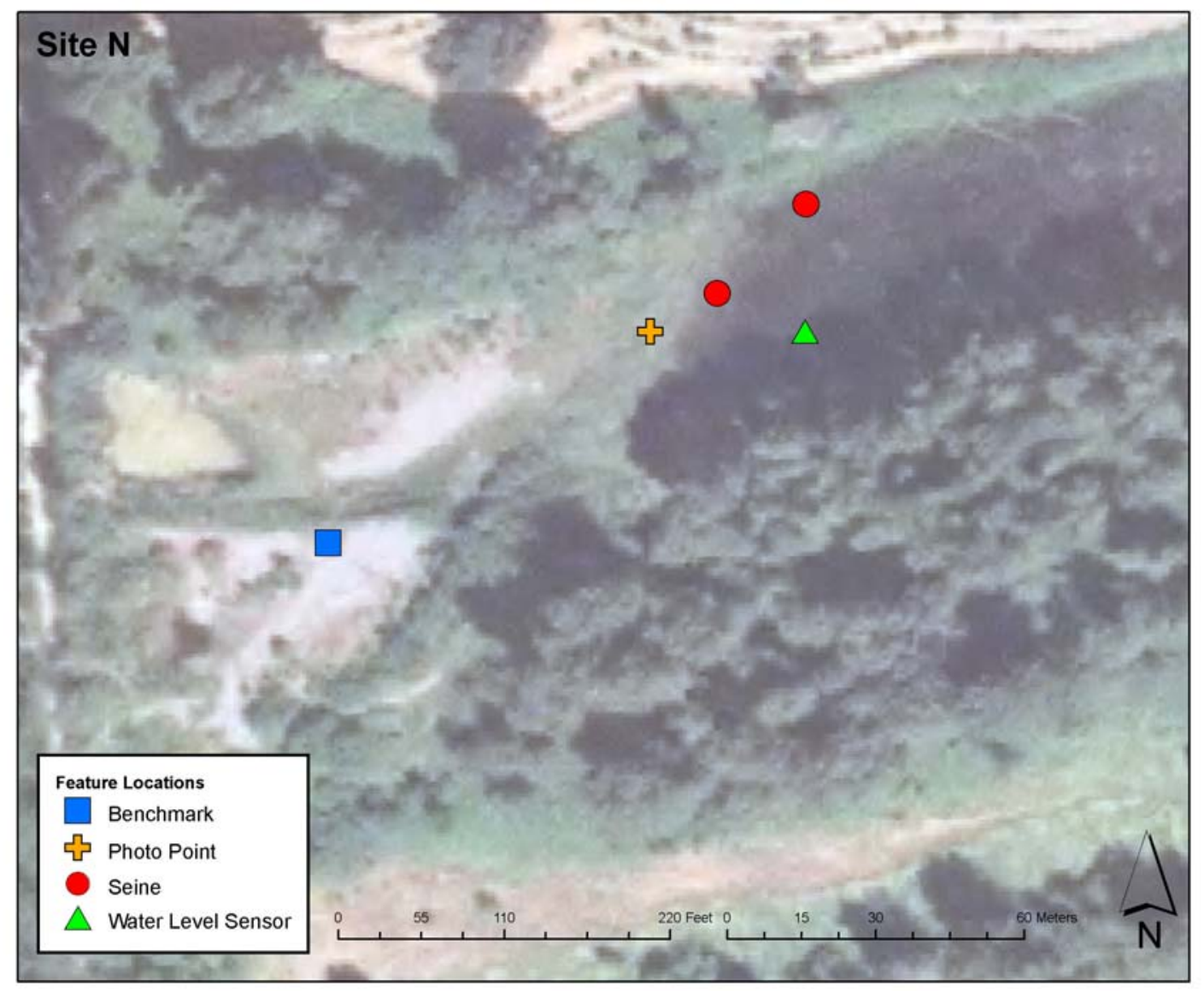

Figure 12. Site N, with Locations of Seine Hauls and Ancillary Points 
Following three months of data collection, we held a project meeting (August 16, 2007) to evaluate operations and review the results to date. Due to concerns over site comparisons related to the application of results of this study to evaluate the potential restoration at the old Sandy River channel, we added an additional site (E) on the south side of Gary Island (Figures 7 and 13). Like Site B at Chatham Island, this site has a relatively steep drop-off and deep water ( $>1.5 \mathrm{~m}$ ) with extensive submerged aquatic vegetation at low water. However, the beach face is well vegetated leading to a riparian berm with large cottonwoods. Site $\mathrm{E}$ is the only site lacking a water surface elevation/temperature logger for 2007; one will be installed in 2008. An acoustic node was deployed upstream of the sample site, in a deep hole $(\sim 10 \mathrm{~m})$ east of the Gary Island.

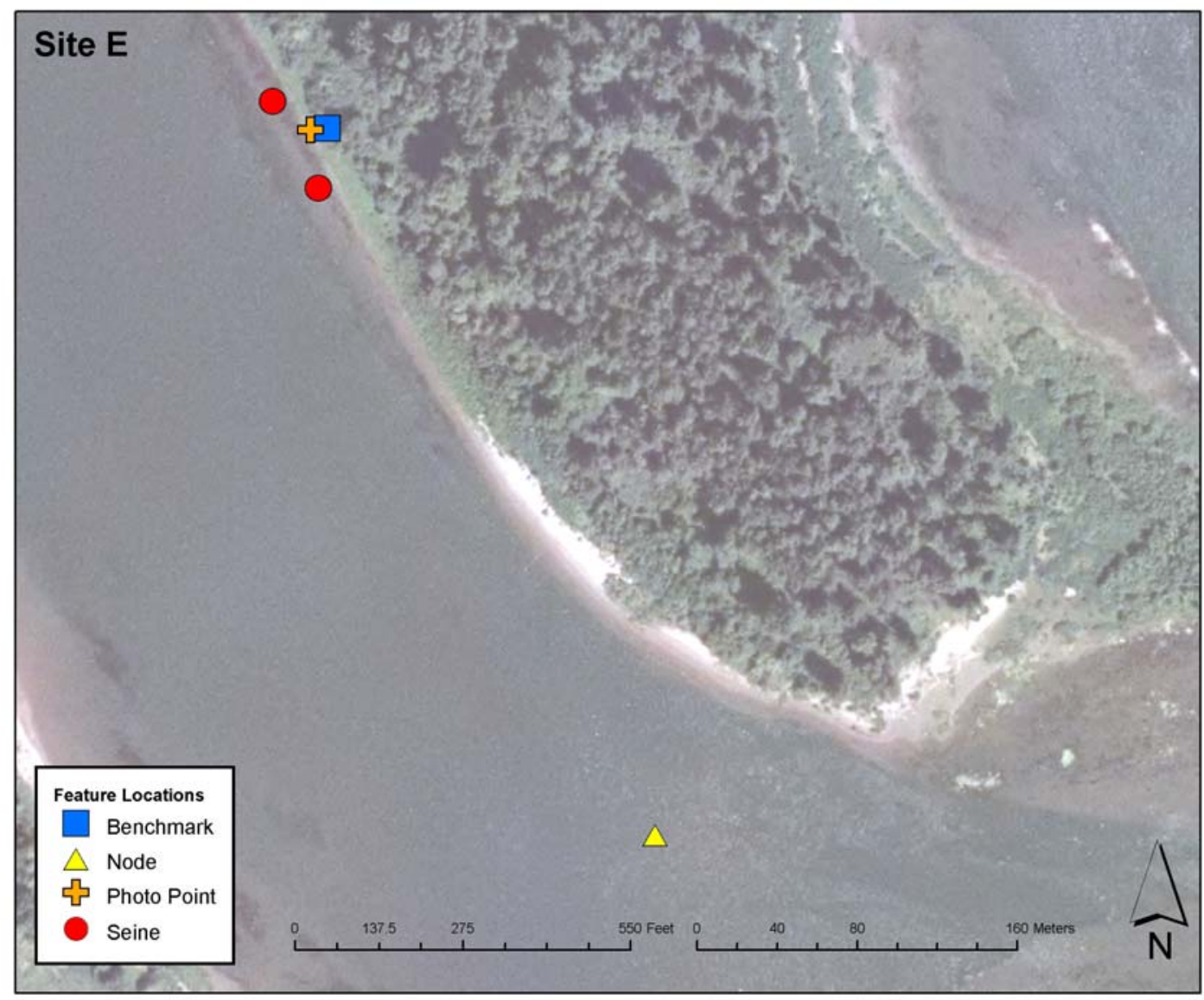

Figure 13. Site E, with Seine, Benchmark, Photo Point, and Acoustic Node Locations 


\subsubsection{Seining Schedule}

The six sampling sites were selected to address the primary objective of assessing habitat and fish community characteristics for juvenile salmonid in tidal freshwater in the vicinity of the Sandy River Delta. Beach seine efforts at Sites B, C, D, and N occurred twice in June and once monthly from July through December. Site A was sampled monthly beginning in August when we obtained our Washington State collection permit. Sampling at Site E, our sixth sampling station, was initiated in September. Except for Site N, because we accessed it by walking, not by boat, the daily sampling order for each of the sites was selected randomly. To avoid unnecessary logistical constraints, Site $\mathrm{N}$ was sampled prior to or following the boat sites on a given day. All sampling dates are provided in Table 1.

Table 1. Sampling Dates during 2007 for the Tidal Freshwater Monitoring Study

\begin{tabular}{|c|c|c|}
\hline Month & Dates Sampled & Sites Sampled \\
\hline \multirow[t]{2}{*}{ June I } & $6 / 5 / 2007$ & $\mathrm{~N}$ \\
\hline & 6/6/2007 & B, C, D \\
\hline \multirow[t]{2}{*}{ June II } & 6/26/2007 & $\mathrm{D}, \mathrm{N}$ \\
\hline & 6/27/2007 & $\mathrm{B}, \mathrm{C}$ \\
\hline \multirow[t]{2}{*}{ July } & $7 / 11 / 2007$ & B, C, D \\
\hline & 7/19/2007 & $\mathrm{N}$ \\
\hline \multirow[t]{2}{*}{ August } & $8 / 14 / 2007$ & $\mathrm{~B}, \mathrm{C}, \mathrm{N}$ \\
\hline & $8 / 15 / 2007$ & A, D \\
\hline \multirow[t]{2}{*}{ September } & 9/11/2007 & $\mathrm{B}, \mathrm{D}, \mathrm{E}$ \\
\hline & 9/12/2007 & A, C, N \\
\hline \multirow[t]{2}{*}{ October } & $10 / 16 / 2007$ & A, E, N \\
\hline & $10 / 17 / 2007$ & B, D \\
\hline \multirow[t]{2}{*}{ November } & 11/19/2007 & A, B, C \\
\hline & $11 / 20 / 2007$ & E, D, N \\
\hline \multirow[t]{2}{*}{ December } & $12 / 18 / 2007$ & $\mathrm{~A}, \mathrm{~B}, \mathrm{E}$ \\
\hline & 12/19/2007 & N, C, D \\
\hline
\end{tabular}




\subsection{Habitat Characteristics}

\subsubsection{Physical Features}

Substrate. To characterize substrate, we collected sediment samples at low-water during the September sampling trip. At each site, we collected grab samples ( $200 \mathrm{ml})$ at three locations near the water's edge (upstream, middle, and downstream; randomly labeled 1, 2, or 3). Samples were refrigerated prior to analysis. Columbia Analytical Services performed grain size analysis according to the Puget Sound Estuary Program protocol (Puget Sound Estuary Program 1986). Quality assurance measures were followed by the laboratory. Reported values include the average of the three samples per site, with percent contribution for each of eight size classes.

Slope/Bathymetry. Because variation in water level throughout the year results in a seasonal location-shift down the beach face to be at the water's edge, we collected three to four elevation transects at each site to document relative beach slope. Coinciding with a period of low water, we laid out field tapes creating parallel lines; we collected elevation data using a Trimble real time kinematic (RTK) global positioning system (GPS; Trimble Navigation Limited, Sunnyvale, CA), with survey-grade accuracy, at regular intervals along the lines, generally every meter or every other meter, depending upon transect length and change in slope. These transects extended from the height of the berm (high water line) into the water to approximately waist-depth at each site.

All surveying was referenced to the North America Vertical Datum 88 (NAVD 88); horizontal position was referenced to North America Datum 83 (NAD 83). Data collected from the base receiver were processed using the automated Online Positioning User Service (OPUS) provided by the National Geodetic Survey. To ensure proper spatial reference, OPUS provides a root-meansquare value, an estimate of error, for each set of static data collected by the base receiver.

We used Trimble Geomatics Office (TGO 2005) to process the data, importing, reviewing and annotating each survey. Benchmark information was entered and rover antenna heights were corrected for disc sink measured at each survey point to the nearest half inch; this step is critical in soft-muddy sediments to assure an accurate elevation. The survey was then recomputed within Trimble Geomatics Office and exported in a GIS shapefile format. Surveys were visually checked within Trimble Geomatics Office and ArcGIS (ESRI 2004) software for validity.

Water Quality. During low water, we installed Onset Hobo Water Level Loggers (Model U20001-01; Onset Computer Corporation, Pocasset, MA) at Sites A-D and N. These sensors measure temperature and water surface level using an unvented pressure sensor. All sensors were new from the factory and were set to record at 30-minute intervals. To install the sensors, we drove a metal fencepost into the sediment until an approximate height of $1.5 \mathrm{~m}$ of fencepost remained above the substrate. Sensors were installed within a protective polyvinyl chloride sleeve and attached to the fencepost with hose-clamps and cable ties. At the time of installation (August), the sensors were approximately $0.25 \mathrm{~m}$ off the substrate and were submerged under $\sim 1.5 \mathrm{~m}$ of water. Exact water level 
measurements were collected and each sensor was surveyed using the RTK GPS to obtain accurate elevations.

\subsubsection{Vegetation}

To assess vegetation occurrence and abundance we utilized two methods: transect surveys with percent cover quadrats for species distribution and vegetation mapping using a hand-held GPS unit for overall assemblage characterization.

Species Distribution. To characterize vegetation species, we determined the optimum location of transects such that all major plant communities from the water's edge to the upland would be included in the survey. Typically, we established three transects at each site, radiating from a hub near the water's edge, to capture vegetation banding typical of tidal-freshwater sites (Sobocinski et al. 2005). Along each transect we estimated percent cover every two meters (every three meters if the transect was over $100 \mathrm{~m}$ long and/or the vegetation was deemed homogeneous). At each station on the transect tape, a $1-\mathrm{m}^{2}$ quadrat was placed on the substrate and percent cover was estimated by two observers. An average of the two observations was entered for each station to minimize observer bias. In addition to vegetative cover, features such as bare ground, open water, wood, and wrack were recorded. When plants could not be identified in the field, we collected a sample for later identification using keys or manuals. Where visibility through the water column allowed, cover estimates were also estimated for submerged aquatic vegetation.

In the field, we entered all data on data sheets and later transferred the data into Microsoft Excel at the lab. Quality assurance checks were performed on a subset of the data entered. Additionally, a field notebook with written observations was maintained.

Mapping. Using a Trimble GeoXT handheld GPS unit (Trimble Navigation Limited, Sunnyvale, CA), we mapped the extent of each site (using reasonable natural boundaries) and delineated major vegetation bands and patches. Additionally, features of importance to the field survey (including benchmarks, transect start/end points, and photo points, see ancillary data below) were also identified and cataloged. All data were input to ArcGIS and maps of each site showing major communities and features were created.

Elevation. Along with each vegetation quadrat, we collected elevation data using the RTK GPS. The instrument was placed in the center of the quadrat and a position (X, Y, and Z coordinates) was recorded for that location. Once processed (see above for details on processing), we entered elevations from the survey into the Excel spreadsheet to correspond to the appropriate transect and quadrat location. We used these data to analyze the occurrence of species at different elevations and to compare with other sites in the tidal freshwater area of the lower Columbia River.

Similarity. To compare the species occurrence at the suite of sites in our study we used a simple similarity index (Czekanowski Index, Thom at al. 2002) whereby, the percent similarity equals:

$$
(2 a /(2 a+b+c)) * 100
$$


Where $a$ is the number of species in common between two sites, $b$ is the number of species exclusive to the first record and $c$ is the number of species exclusive to the second record. By using the number of species in common between two sites, as well as species unique to each site, this index allows for a coarse comparison between sites.

\subsection{Fish Community Characteristics}

The methods for fish community characteristics involved direct capture with a beach seine, ancillary data collection, and genetic sample collection, processing, and analysis for stock identification.

\subsubsection{Direct Capture}

Collection. We assessed fish species composition and catch by collecting duplicate samples from each fixed site using a standard beach seine (30.5 m x $3 \mathrm{~m}$; $5 \mathrm{~mm}$ bar knotless mesh). Nets were deployed by boat or on foot depending on water depth and site accessibility at the time of sampling. To ensure independent samples, we allowed at least $1 / 2 \mathrm{~h}$ between replicate hauls and moved upstream to undisturbed water for the second haul. Following each haul, we removed captured fish from the net and placed them in holding buckets filled with river water at ambient temperature. When catches were large, we used aerators to maintain adequate levels of dissolved oxygen in the holding water. All observed mortalities were documented. We released fish processed from the first haul downstream of the sampling area to minimize potential contamination of the second sample; fish from the second haul were released at the site of capture.

Processing. For each set, we identified salmon to species and recorded fork length (FL) to the nearest mm for up to 20 fish of each species; individuals encountered after 20 fish had been measured were enumerated. We excised small sections of pectoral fin from up to 20 salmon per sample site to provide material for genetic mixture analysis. All pectoral fin samples were preserved in $90 \%$ ethanol solution. Origin (hatchery or wild/natural origin) of all captured salmon was determined by noting the presence or absence of clipped adipose fins, coded-wire tags (CWTs), or passive integrative transponder (PIT) tags ${ }^{1}$. We identified CWTs and PIT tags by scanning salmonids with a handheld Wand detector (Northwest Marine Technology, Shaw Island, Washington) and a Pocket Reader (Biomark Incorporated, Boise, Idaho), respectively. We identified non-salmonid fishes to the lowest taxonomic classification possible and recorded lengths (nearest mm; FL or total length [TL] depending on taxon) for up to 20 individuals in each taxon. We enumerated remaining non-salmonid catch after 20 individuals from each taxon had been measured.

\footnotetext{
${ }^{1}$ We are, for this report, identifying non-tagged and non-fin-clipped fish as wild (wild or naturally spawned and reared) even though we understand that many hatchery groups from all over the basin are released without marks and therefore some proportion of unmarked fish are likely of hatchery origin.
} 
Analysis. With the primary focus of this study aimed at investigating juvenile salmon ecology in shallow tidal freshwater habitats, detailed information related to species abundance, size-class frequency, and stock origin were summarized for all salmonid species. We estimated densities (individuals $/ \mathrm{m}^{2}$ ) and catch per unit effort (CPUE) at each site for juvenile salmon and selected nonsalmonids from collected data. Descriptive data pertaining to species assemblages were summarized for non-salmon species with a focus on the most prevalent species encountered. Trends in the fish community composition throughout the sampling season were further examined according to sites and habitat characteristics.

\subsubsection{Ancillary Data}

At each site, we documented a number of ancillary metrics. During the first sampling trip, a station, or photo point, was designated from which photographs were taken on each subsequent sampling trip to document the seasonal changes at the site. From the photo point, the photographer panned the river capturing a series of photographs that were archived after each trip.

Because water level fluctuates to such a large extent at the sampling sites, we adopted several approaches to quantify this variation. Above the influence of tides, we installed a length of re-bar as a benchmark from which all local elevation measurements were made. This benchmark was surveyed using RTK GPS (see above for description of survey methods) and tied to an elevation control point off-site. During each sampling period, we measured the distance from the benchmark to the water's edge as a gauge for seasonal shifts in water level. After each seine haul was completed, we collected GPS points at the mid-point to record where the seine haul occurred in that month. These GPS points were imported to ArcGIS (ESRI 2004) for mapping.

During each trip, conventional water quality parameters were measured at each site. Using a hand-held YSI 85 (Yellow Springs Instruments, Yellow Springs, $\mathrm{OH})$, we collected temperature $\left({ }^{\circ} \mathrm{C}\right)$, dissolved oxygen (mg/L), and salinity (parts per thousand) data. The probe was held in the middle of the water-column, with total water depth approximately $0.3 \mathrm{~m}$. Measurements were recorded on a field data sheet and later input to a spreadsheet with the corresponding catch data from each trip.

Starting in September, we also measured river velocity at the sites, using a Flo-Mate electromagnetic flow meter (Marsh-McBirney Inc., Frederick, MD). In general, velocity at the sampling sites was quite low, occasionally tending upstream due to local eddies or other current disruptions.

In addition to in-situ measurements, we collected data on river condition from the USGS (http://waterdata.usgs.gov/nwis/uv?14144700) and DART (http://www.cbr.washington.edu /dart/river.html) websites. Data included: gauge height at Vancouver, WA (USGS), spill and outflow from Bonneville Dam (DART), and scroll case temperature at Bonneville Dam (DART). All data were associated with the nearest sampling date and time (e.g. fish collected at 10:50 am and data were listed at 30-minute increments, 11:00 am data were used). All ancillary data were input to a master spreadsheet for use in analysis. Photos and GPS points were archived according to type. 


\subsubsection{Genetics}

Collection. Fin clips on sub-samples of salmon ( 15 per sample site per trip) were preserved in ethanol for genetic mixture analysis. A total of 121 clips were sent the NMFS laboratory for genetic analysis as part of the 2007 Tidal Freshwater Monitoring Study.

Processing and Analysis. We used standard methods of genetic stock identification and individual assignment (recently reviewed by Manel et al. 2005). Chinook salmon were genotyped using the methods described in Van Doornik et al. (2007). Data were collected for 13 microsatellite loci that have recently been standardized among several west coast genetics laboratories (Seeb et al. 2007). Genetic mixture analysis and the relative probability of stock origin of each sample were estimated using the genetic stock identification computer program ONCOR (Kalinowski et al. 2007). Population baseline data were from the multi-laboratory standardized Chinook salmon genetic database described by Seeb et al. (2007). Mixture proportions and assignments probabilities for individual baseline populations were summed to nine Columbia River Basin stock groups (Table 2). Confidence intervals of the mixture proportions were estimated using ONCOR by re-sampling mixture and baseline data 100 times.

Table 2. Genetic Stock Group and Baseline Populations

\begin{tabular}{|c|c|}
\hline Genetic Stock Group & Baseline Populations \\
\hline $\begin{array}{l}\text { West Cascade Tributary } \\
\text { Fall }\end{array}$ & Cowlitz Hatchery, Lewis River, Sandy River \\
\hline West Cascade Tributary & Cowlitz Hatchery, Kalama Hatchery \\
\hline Spring & Lewis Hatchery, \\
\hline Willamette River Spring & $\begin{array}{l}\text { Mckenzie Hatchery and River, North Santiam Hatchery and River, North } \\
\text { Fork Clackamas River }\end{array}$ \\
\hline Spring Creek Group Tule & Spring Creek Hatchery, Big Creek Hatchery \\
\hline Fall & Elochoman River, Willamette River \\
\hline Deschutes River Fall & Lower Deschutes River, Upper Deschutes River \\
\hline $\begin{array}{l}\text { Upper Columbia River } \\
\text { Summer/Fall }\end{array}$ & Handford Reach, Methow River, Wells Hatchery, Wenatchee River \\
\hline Mid and Upper & Carson Hatchery, John Day River, Upper Yakima River, Warm Springs \\
\hline Columbia River Spring & Hatchery, Wenatchee Hatchery and River \\
\hline Snake River Fall & Lyons Ferry Hatchery \\
\hline Snake River Spring & $\begin{array}{l}\text { Imnaha River, Minam River, Rapid River Hatchery, Secech River, } \\
\text { Tucannon Hatchery and River, Newsome Creek, West Fork Yankee } \\
\text { Creek }\end{array}$ \\
\hline
\end{tabular}




\subsection{Fish Catch Variance Analysis}

The study will provide estimates of variance components needed to determine sample sizes for consummate investigations and an evaluation of the sampling gear used to monitor the fish populations.

Considering the replicate beach seines within a site as repeated measures of the same local response (i.e., measurement or sampling error), the data within a survey period can be used to estimate spatial variability $\left(\sigma_{s}^{2}\right)$ and average measurement error $\left[\right.$ i.e., $\left.\widehat{\widehat{\operatorname{Var}}\left(\hat{x}_{i} \mid x_{i}\right)}\right]$ by habitat type. For example, consider $k$ replicate sites within a habitat and $n$ replicate samples per site, then a oneway ANOVA can be used to estimate the variance components as shown in Table 3.

Table 3. ANOVA Used to Estimate Variance Components

\begin{tabular}{lllll}
\hline Source & DF & SS & MS & E(MS) \\
\hline Total $_{\text {Cor }}$ & $n k-1$ & SSTOT $_{\text {Cor }}$ & & \\
Between sites & $k-1$ & SST & MST & $\overline{\operatorname{Var}\left(\hat{x}_{i} \mid x_{i}\right)}+n \sigma_{S}^{2}$ \\
Within sites & $n k-k$ & SSE & MSE & $\overline{\operatorname{Var}\left(\hat{x}_{i} \mid x_{i}\right)}$ \\
\hline
\end{tabular}

From the one-way ANOVA table above, average measurement error is estimated by MSE and spatial variance $\left(\sigma_{S}^{2}\right)$ by the expression

$$
\hat{\sigma}_{S}^{2}=\frac{\mathrm{MST}-\mathrm{MSE}}{n} \text {, }
$$

where $k=$ number of sites and $n=$ number of replicate samples per locations (e.g., 2).

In many biological systems, particularly for abundance data, the variance increases as the mean abundance increases. In such cases, the variance tends to follow the negative binomial rule where

$$
\sigma_{S}^{2}=\mu+\frac{\mu^{2}}{c,(2)}
$$

where ${ }^{\mu}=$ mean abundance and $c$, negative binomial coefficient. In other cases where the data are log-normally distributed, such as catch-per-unit-effort data,

$$
\sigma_{S}^{2}=c \mu^{2}
$$


in other words, the coefficient of variation $(\sigma / \mu)$ is constant. Repeated sampling across the seasons and habitats will be used to determine the best characterization for $\sigma_{S}^{2}$ for subsequent sample size calculations. Similar mean-variance relationships often hold for measurement error as well. Based on the most appropriate variance-to-mean relationship, data will be pooled across sampling events to obtain more precise estimates of the variance components for subsequent sample size calculations.

Estimates of Correlation. The degree of correlation between sites over time is important in any monitoring program that uses a paired design. This correlation within a habitat category can be estimated using the intra-class correlation coefficient (Zar 1999: p.404-407) estimated from a oneway analysis of variance (ANOVA). Patterns in the correlations between different habitats and response variables will be examined. In paired-plot designs, those responses with the highest correlation will tend to have the smallest overall error variance and have a better opportunity to detect change over time. Conditions between years, important in the ability to detect time trends and important in optimally designing rotational studies, will be calculated using the standard Pearson correlation coefficient. Details pertaining to the analysis of estimates of correlation are available in Appendix B.

BACI Analysis. Partial site selection for this study was intended to address a before-after, control-impact (BACI) design criteria in anticipation of the proposed mitigation project to reconnect the Sandy River with its historic delta (Skalski and McKenzie 1982). This approach selects sites B and $\mathrm{E}$ as control sites, while sites $\mathrm{C}$ and $\mathrm{N}$ are considered within the zone of potential impact as a result of restoration activities. As open channel sites, $\mathrm{C}$ and $\mathrm{E}$ will be paired, while sites $\mathrm{N}$ and $\mathrm{B}$ are paired as backwater habitats. In the event that restoration occurs during the study period, data gathered from pre- and post-restoration monitoring will be applied to the two pairs of sites. The current results of our sampling efforts fulfill the pre-restoration monitoring aspect of the BACI design. A complete analysis of this method will be conducted following post-restoration monitoring activities.

\subsection{Acoustic Telemetry}

Equipment: A basic acoustic telemetry system consists of a tag (the transmitter), a hydrophone (the receiving transducer, or node), a signal processor, and processing and analysis software. This system can be used to detect the presence of a tagged animal in an area of interest. The microacoustic tags used in this study transmit $417 \mathrm{kHz}$ sound once every 5 seconds for about 60 days. The equipment we used was developed as part of the JSATS program (for more information, see McComas et al. 2007).

Fish Tagging and Release: As part of other projects (e.g., Corps EST-P-02-01), over 23,000 juvenile salmon and steelhead were implanted with acoustic tags and released in the hydrosystem above Bonneville Dam. Individual fish were surgically implanted with acoustic tags weighing no more than $0.63 \mathrm{~g}$ in air ( $0.39 \mathrm{~g}$ in water) using a procedure similar to that described by Adams et al. 
(1998). Each fish received a PIT tag and an acoustic tag no larger than $5.5 \mathrm{~mm}$ wide $\mathrm{x} 4.8 \mathrm{~mm}$ thick $\mathrm{x}$ $19 \mathrm{~mm}$ long.

Sampling Sites: The Tidal Freshwater Monitoring Study utilized fish tagged and released upstream as part of other studies by sampling for JSATS-tagged fish within the study area. Four autonomous hydrophones (called nodes) were deployed in relatively deep holes in the study area (Figure 7): Reed Island - near seine Site A; Gary Island - near seine Site E; Chatham Island - near seine Site B; Old Sandy Channel - near seine Site C. Due to a required minimum water depth of $\sim 2$ $\mathrm{m}$ for the nodes, we were limited in our ability to locate sensors proximal to our seine sites. The node at the old Sandy Channel (just upstream of Site C) was located in the deepest hole in the area, approximately $2 \mathrm{~m}$ deep at low water, which was the shallowest condition possible with the current configuration. Another node was located in the cut between Gary Island and Flag Island, in a very deep hole (> $10 \mathrm{~m}$ depth). This node was attached to a mooring and retrieved using an acoustic release device. The node located in the cut between Chatham Island and the mainland along I-84 (approximately $200 \mathrm{~m}$ upstream of our seine site) was in moderately deep water ( $5 \mathrm{~m}$ ) and was attached to a mooring which was tethered to shore.

We also utilized data from hydrophones deployed upstream and downstream of our study sites, in the mainstem of the Columbia, for other studies to calculate migration rates and pathways. Placing hydrophones upstream of the delta and in the main channel along the outer side of the delta, and in two sites within the delta, was important to demonstrate whether or not the area is used by upriver juvenile salmonids.

Sampling Periods. Nodes were deployed in May and retrieved in August (Table 4). Sample time ranged from 71 to 124 days, depending on the node. We lost 25 days of sample time at the Chatham Island node because of a flash card malfunction. An undetermined amount of time was lost at the Old Sandy Delta node because the node was pulled out of the water by a passerby.

Table 4. Sample Periods, Servicing Dates, and Total Sample Days for Telemetry Receiving Nodes

\begin{tabular}{ccccc}
\hline Date & Reed Is. & Chatham Is. & Gary Is. & Old Sandy Delta \\
\hline $4 / 27$ & Deployed & & Deployed & \\
$5 / 11$ & & Deployed & & Deployed \\
$5 / 18$ & & Serviced & & \\
$5 / 31$ & Serviced & Serviced & Serviced & Serviced \\
$6 / 27$ & Serviced & Off-Line & Serviced & Serviced \\
$7 / 23$ & Serviced & Serviced, On-Line & Serviced & Serviced \\
$8 / 14,15$ & & Retrieved & Retrieved & Retrieved \\
$8 / 18$ & Retrieved & & & \\
Days Lost & 2 & $25 *$ & 0 & 0 \\
Total Days & 124 & 71 & 110 & 95 \\
\hline
\end{tabular}

* Days were lost at the Chatham Island site because of a flash card malfunction. 
Data Downloading: Acoustic data were downloaded from the mini-nodes each month of the April-September telemetry field season. Node "servicing" consisted of recovering each node and replacing the batteries and data media (i.e., a CompactFlash card). Data were immediately backed up on the project laptop computer and CD media.

Data Analysis. This aspect of the study will help us assess the feasibility of using acoustic telemetry technology for action effectiveness research in the LCRE. We assessed whether detections of tagged salmonids at each of the hydrophones could be used to determine the spatial distribution and residence time of tagged fish at the sample sites. Detections of tagged fish through time could then be used to determine the temporal distribution of tagged fish at the study sites. A detection event was defined as at least four valid acoustic signal receptions within a $60 \mathrm{sec}$ window. We matched detected fish with release codes and developed time-of-detection histories. We uploaded the data to the TagViz database at PNNL in Richland which contains tag activation and detection histories for all JSATS studies in 2007. The primary data from the analysis of the acoustic data were species of tagged fish, time of first detection, time of last detection, residence time, location(s) (i.e., nodes, where detections occurred), and total number of valid detections. These data were analyzed in conjunction with data from JSATS nodes for the Bonneville Spillway Survival Study placed across the Columbia River at Reed and Lady Islands just upstream and downstream, respectively, from the Sandy River delta study area. 


\subsection{Results}

In this section, results are presented for data collected during June to December 2007 for the Tidal Freshwater Monitoring Study. Habitats and fish communities are characterized and compared among six sampling sites (Objective 1) and acoustic telemetry data are assessed (Objective 2).

\subsection{Habitat Characteristics}

\subsubsection{Physical Features}

Water Quality. Data from the five water temperature and depth sensors, which were installed during low-water and are recording throughout the year at 30-minute intervals, will be retrieved in summer 2008.

Substrate. At all sites, sediment was typically sandy, with lower proportions of coarser sediments and finer sediments mixed in (Table 5). Sediments tended toward the finer end of the sand class range, with the most dominant categories being fine sand, very fine sand, and silt. Only one site, D, had a high proportion of gravel in the sediment and this was a direct result of one of the three subsamples containing a disproportionately high percentage of gravel (D3 was 43\%, while D1 and D2 were both $<1 \%)$.

Table 5. Sediment Grain Size Average Percent Composition. Highlighted cells indicate size classes with the highest percent composition for each site.

\begin{tabular}{lcccccccc}
\hline Site & Gravel & $\begin{array}{c}\text { Very Coarse } \\
\text { Sand }\end{array}$ & $\begin{array}{c}\text { Coarse } \\
\text { Sand }\end{array}$ & $\begin{array}{c}\text { Medium } \\
\text { Sand }\end{array}$ & $\begin{array}{c}\text { Fine } \\
\text { Sand }\end{array}$ & $\begin{array}{c}\text { Very Fine } \\
\text { Sand }\end{array}$ & Silt & Clay \\
\hline A & 1.8 & 0.4 & 0.4 & 2.8 & 16.9 & 31.2 & 40.4 & 3.4 \\
B & 0.2 & 0.8 & 8.7 & 41.5 & 33.0 & 6.1 & 9.2 & 0.9 \\
$\mathrm{C}$ & 5.7 & 12.2 & 17.8 & 26.2 & 14.8 & 4.0 & 14.6 & 1.1 \\
$\mathrm{D}$ & 14.1 & 2.9 & 5.1 & 9.9 & 50.6 & 13.9 & 2.3 & 0.4 \\
$\mathrm{E}$ & 0.4 & 0.6 & 0.7 & 2.0 & 17.5 & 26.9 & 42.8 & 2.1 \\
$\mathrm{~N}$ & 0.3 & 0.6 & 1.0 & 1.5 & 5.0 & 17.3 & 70.5 & 2.0 \\
\hline Average & 3.8 & 2.9 & 5.6 & 14.0 & 23.0 & 16.6 & 30.0 & 1.6 \\
\hline
\end{tabular}

Slope/Bathymetry. Beach slope varied at all sites sampled (A-D and N, Figure 14). Three transects were surveyed for elevation (with the exception of site A, which had four); at each site, there was an upstream transect, a downstream transect and a middle transect (beach seining was typically conducted between the middle and end transects; Figure 15). Site B is the steepest sloping beach, with a constant drop-off resulting in deep water, even during periods of low river flow. Site $\mathrm{D}$ has the most gradual slope within ordinary high water, with a wide expanse of flats extending out from the 
backshore berm. At mid-elevation on the upstream transect, there is a high spot that creates an area of extremely shallow water during low flow conditions. This site slopes steeply to the riparian area and the measurements for this site included riparian area on the upland end and thus more highelevation points. Site C is similar in topography to Site D, with a steep slope from the backshore berm down to an area of shallow flats below $4.5 \mathrm{~m}$. Sites A and $\mathrm{N}$ are similar in having consistent, moderate slope, with little variation between the replicate transects.

In addition to using the field collected data, we analyzed available light detection and ranging (LiDAR) data for determining beach topography in the area of interest. Because LiDAR data were collected during high river flow, only returns above the water level are accurate, and therefore, most data from the shallow water area of interest is associated with high error (see more in discussion below).

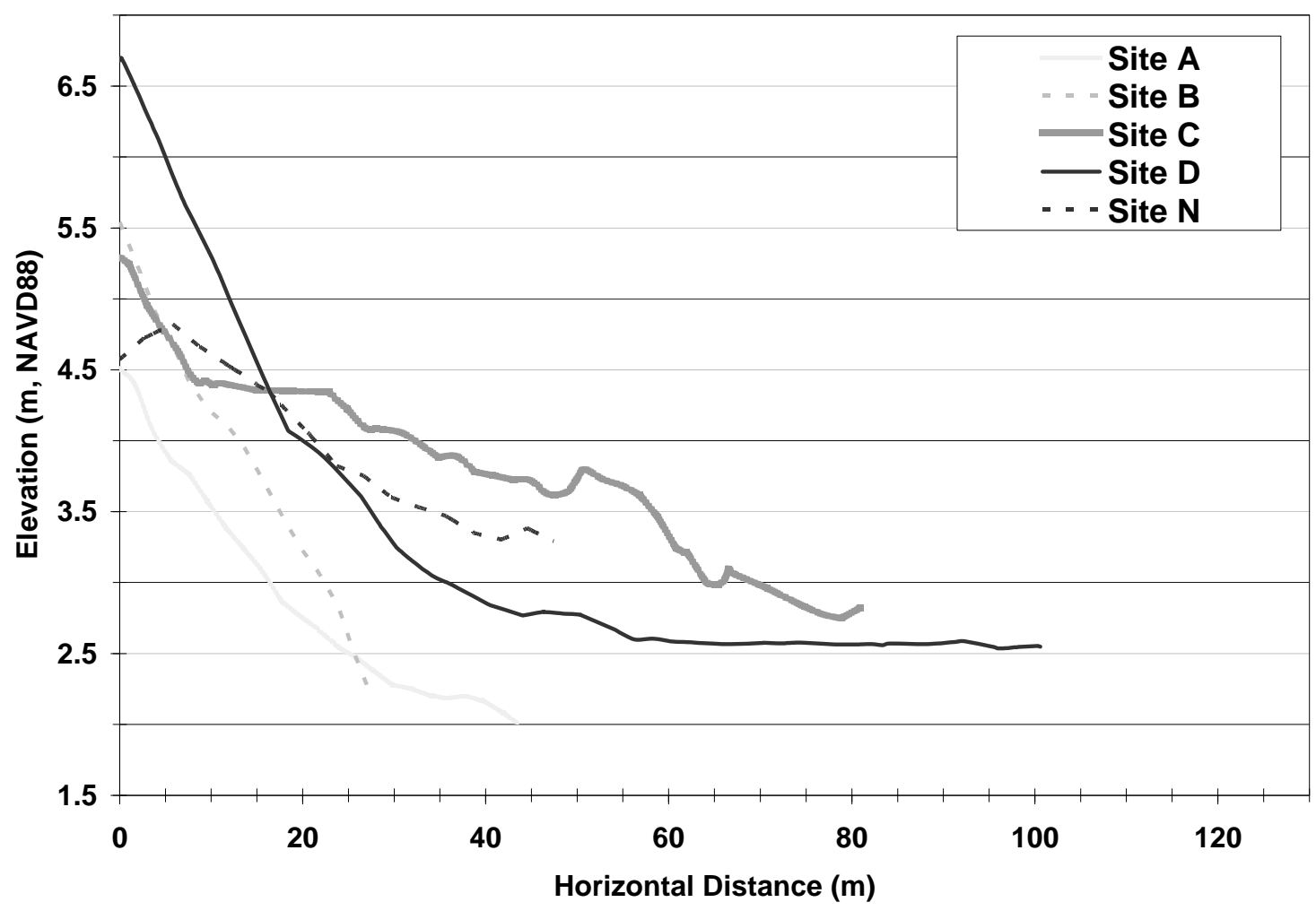

Figure 14. Beach Slope at the Sampling Sites 

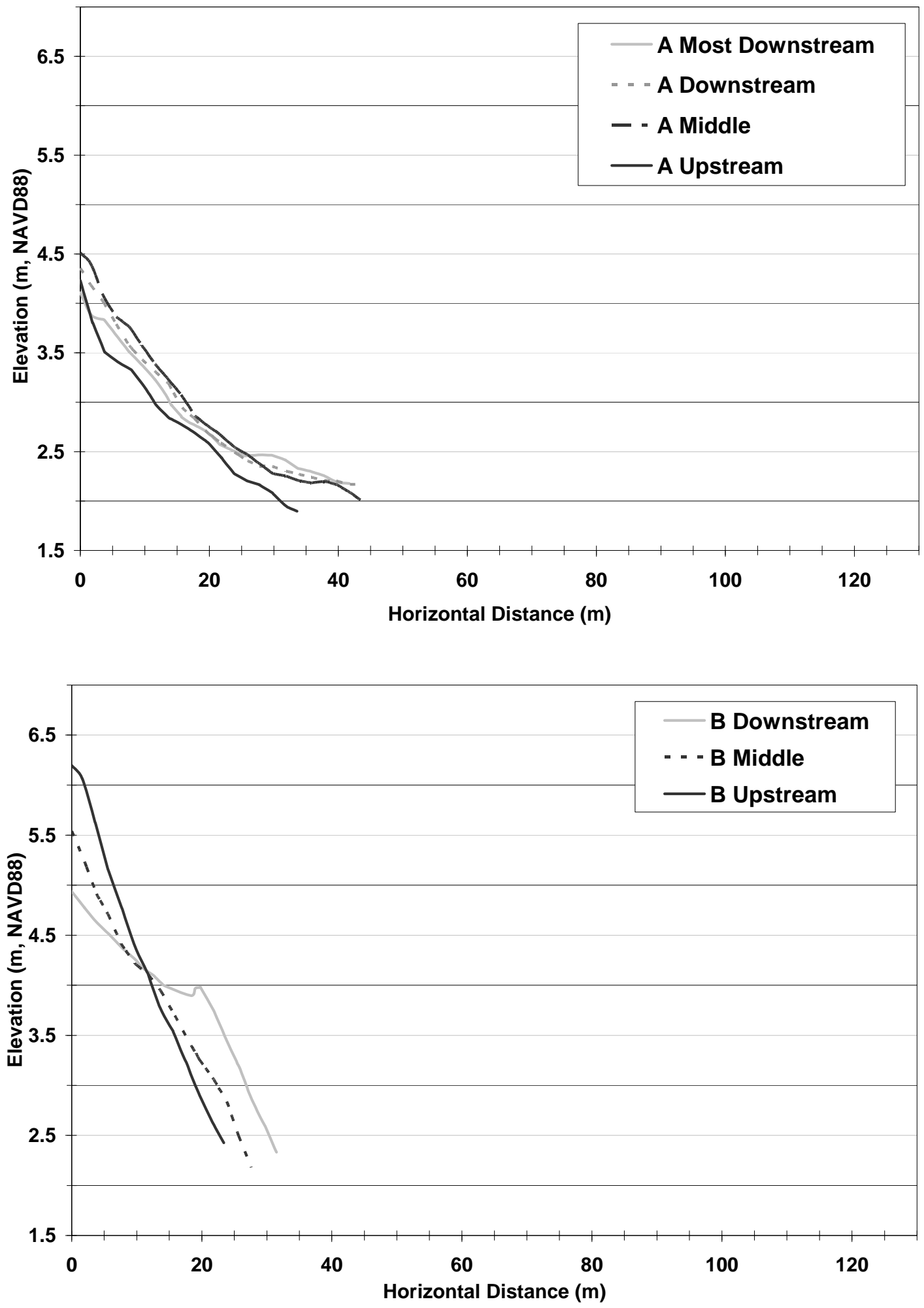

Figure 15. Beach Slope by Sampling Site. Sites A and B. Lines represent multiple transects at each site. 

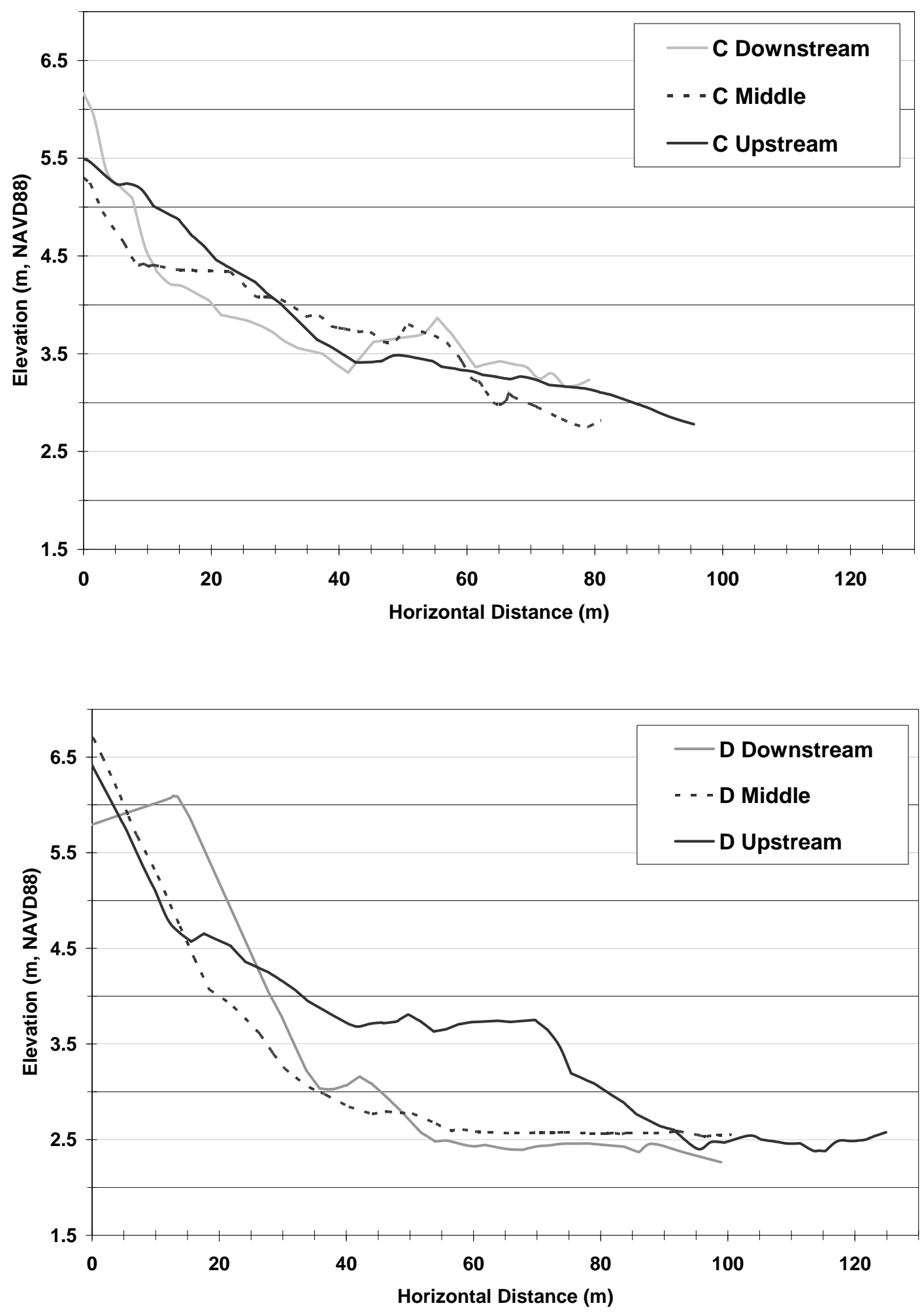

Figure 15. Cont. Beach slope at Sampling Sites C and D. Lines represent multiple transects at each site. 


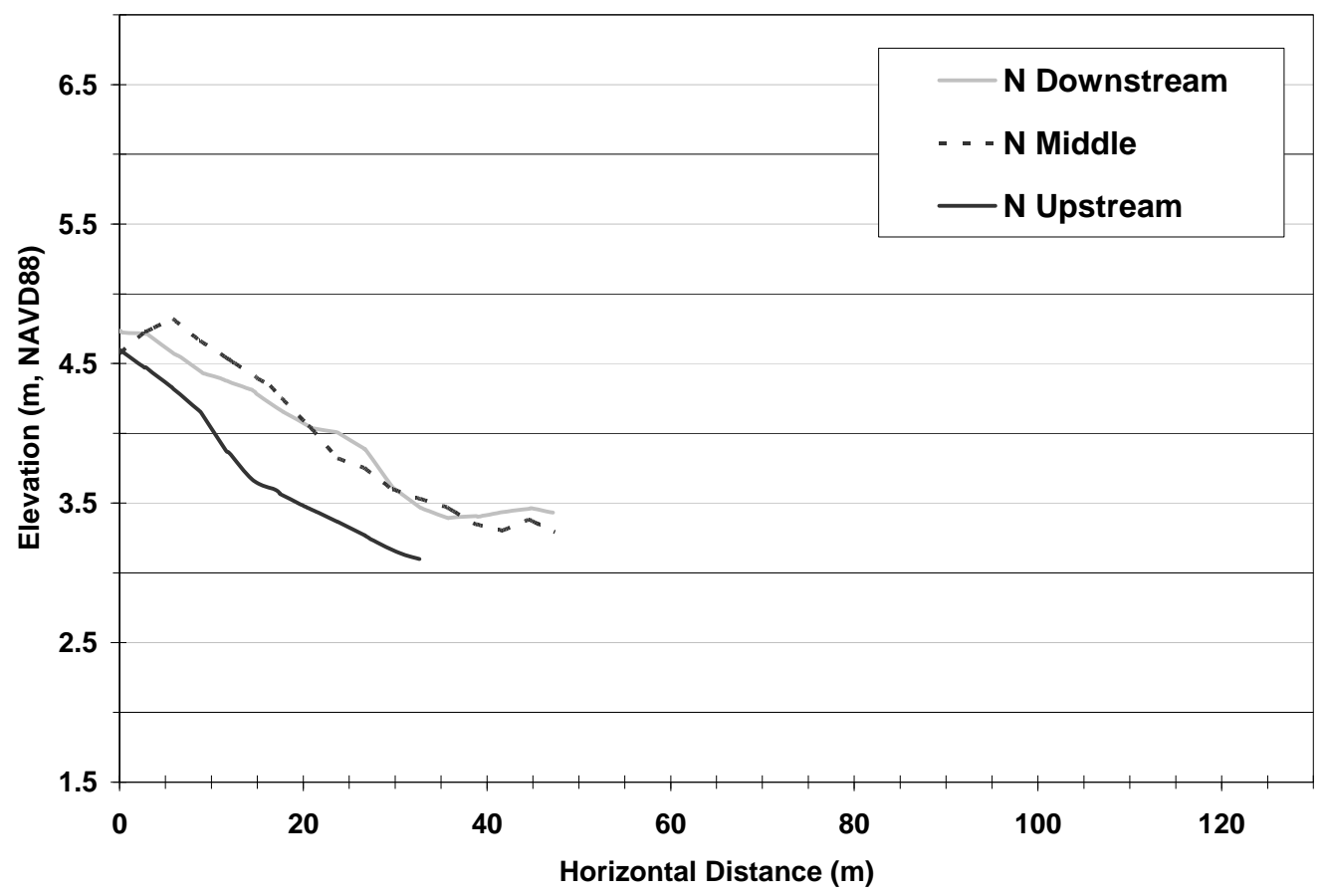

Figure 15. Cont. Beach Slope at Sampling Site N. Lines represent multiple transects at each site.

\subsubsection{Vegetation}

The sites selected for fish sampling were necessarily free of shrub and tree vegetation in the area where we hauled the beach seine, however, all sites had emergent marsh vegetation along the shoreline and riparian vegetation nearby. Previous work through LCREP has shown a typical banded emergent marsh pattern, driven mostly by hydrology. In these emergent marshes, the lowest vegetation tends to be sedges (Carex spp.) and spikerushes (Eleocharis spp.), with wapato (Sagittaria latifolia) in finer sediments with perennial standing water. Mid-elevation is characterized by sedges or grasses (family Poaceae) such as rice cut-grass (Leersia orizoides) or the highly invasive reedcanary grass (Phalaris arundinacea). Reed-canary grass has a wide elevation range and can extend above ordinary high water. Often, in the upper areas of the reed-canary grass zone, willows (Salix spp.) and cottonwood (Populus balsamifera) saplings become established. These general vegetation patterns were represented at the sites in this study as well.

We found a total of over 55 species at our study sites (Table 6), with an average of 28 species per site. Site $\mathrm{N}$ was the least diverse with 20 species represented and Site $\mathrm{C}$ was the most diverse with 38 species observed. It should be noted that the sampling effort was not equal at all sites; at some sites, transects were longer or sampling frequency was greater compared to other sites. However, with the exception of Site A (which was fairly uniform in character throughout), we collected at least 60 quadrat samples at each site. Previous vegetation survey work in the LCRE (Sobocinski et al. 2005) showed that the number of new species encountered at tidal freshwater sites decreased after approximately 60 samples; the level of sampling effort at our sites was guided by this previous work. 
Table 6 Vegetation Species Found at Tidal Freshwater Monitoring Study Sites, with Common and Scientific Names

\begin{tabular}{|c|c|c|c|}
\hline Code & Scientific Name & Common Name & Sites \\
\hline ALPL & Alisma plantago-aquatica & broadleaf water plantain & $\mathrm{B}, \mathrm{C}$ \\
\hline AMFR & Amorpha fruticosa & indigo bush & A, C \\
\hline BESY & Beckmannia syzigachne & American sloughgrass & $\mathrm{C}, \mathrm{N}$ \\
\hline CA.SP. & Carex spp. & sedge & $A, B, C, D, N$ \\
\hline CAEC & Carex echinata & star sedge & A, B \\
\hline CAOB & Carex obnupta & slough sedge & A, B \\
\hline CEDE & Ceratophyllum demersum & coontail & B, C, N \\
\hline CIDO & Circuta douglasii & western water hemlock & $\mathrm{D}$ \\
\hline COTI & Coreopsis tictoria & golden tickseed & B, C, D \\
\hline CY.SP. & Cyperus sp. & flatsedge & $\mathrm{C}$ \\
\hline DI.SP. & Digitaria sp. & crabgrass & $\mathrm{B}, \mathrm{C}, \mathrm{D}, \mathrm{N}$ \\
\hline ELAC & Eleocharis acicularis & needle spikerush & B, C, D \\
\hline ELCA & Elodea canadensis & common waterweed & B, C, N \\
\hline ELOV & Eleocharis ovata & ovoid spikerush & $\mathrm{C}, \mathrm{N}$ \\
\hline ELPA & Eleocharis palustris & creeping spikerush & A, B, C, D, N \\
\hline ELPAR & Eleocharis parvula & small spikerush & B \\
\hline EPCI & Epilobium ciliatum & willowherb & $\mathrm{D}$ \\
\hline EPLU & Epilobium luteum & yellow willowherb & B \\
\hline EQ.SP. & Equisetum spp. & horsetail & A, B, C, D \\
\hline EUOC & Euthamia occidentalis & western goldenrod & B, C, D \\
\hline FRLA & Fraxinus latifolia & Oregon ash & A \\
\hline GNUL & Gnaphalium uliginosum & marsh cudweed & C, D \\
\hline HEAU & Helenium autumnale & common sneezeweed & $A, B, C, D$ \\
\hline JUAC & Juncus acuminatus & tapertip rush & $\mathrm{N}$ \\
\hline JUOX & Juncus oxymeris & pointed rush & A \\
\hline LEOR & Leersia orizoides & rice cut-grass & A, B, C, D, N \\
\hline LIAQ & Limosella aquatica & water mudwort & $\mathrm{B}, \mathrm{C}$ \\
\hline LIOC & Lilaeopsis occidentalis & western grasswort & $\mathrm{D}$ \\
\hline LUPA & Ludwigia palustris & water-purslane & $\mathrm{A}, \mathrm{B}, \mathrm{C}, \mathrm{N}$ \\
\hline MEAR & Mentha arvensis & field mint & A, C, D \\
\hline MYSP & Myriophyllum spicatum & Eurasian water milfoil & A, B, C, D \\
\hline PADI & Paspalum distichum & knotgrass & B \\
\hline PACA & Panicum capillare & witchgrass & B \\
\hline PHAR & Phalaris arundinacea & reed canary grass & A, B, C, N \\
\hline PLLA & Plantago lanceolata & narrowleaf plantain & C, D \\
\hline PLMA & Plantago major & common plantain & A, B, C, D \\
\hline POAN & Potentilla anserina ssp. pacifica & Pacific silverweed & A, C, D \\
\hline POBA & Populus balsamifera & black cottonwood & $A, B, C$ \\
\hline POCR & Potamogeton crispus & curly leaf pondweed & $\mathrm{A}, \mathrm{B}, \mathrm{C}, \mathrm{N}$ \\
\hline POHY & Polygonum hydropiperoides & mild waterpepper & A, B, C, D, N \\
\hline PONA & Potamogeton natans & floating-leaved pond weed & $\mathrm{D}$ \\
\hline POLA & Polugonum lapathifolium & curly top knotweed & $\mathrm{C}$ \\
\hline POPE & Polygonum persicaria & spotted lady's thumb & $\mathrm{B}, \mathrm{C}, \mathrm{D}, \mathrm{N}$ \\
\hline ROCU & Rorripa curvisiliqua & curvepod yellow cress & C, D \\
\hline RUDI & Rubus discolor & Himalyan blackberry & $\mathrm{C}$ \\
\hline RUSP & Rumex spp. & dock & C, D \\
\hline
\end{tabular}




\begin{tabular}{llll}
\hline Code & Scientific Name & Common Name & Sites \\
\hline SALA & Sagittaria latifolia & wapato & B, C, N \\
SASP & Salix spp. & willow & A, B, C, D, N \\
SCLA & Scirpus lacustris & tule & A, C \\
SESP & Sedum sp. & stonecrop & D \\
SPEM & Sparganium emersum & narrowleaf burreed & N \\
VEAM & Veronica americana & American brooklime & B, D \\
VESP & Veronica sp. & speedwell & D \\
XAST & Xanthium strumarium & rough cocklebur & B, C \\
\hline
\end{tabular}

Maps of vegetation assemblages were made for each site (Figures 16-21). Emergent marsh vegetation dominated all sites, with some submerged aquatic vegetation occurring in perennially wet areas. Emergent species included several herbaceous plants (e.g. Ludwigia palustris, Veronica spp.,) and sedges. Shrub willows were common at all sites and ranged from $<0.5 \mathrm{~m}$ to $>5 \mathrm{~m}$ in height. Site E (which did not have transect surveys) was the most uniform throughout, with distinct bands of vegetation species.

Site A

Reed Island
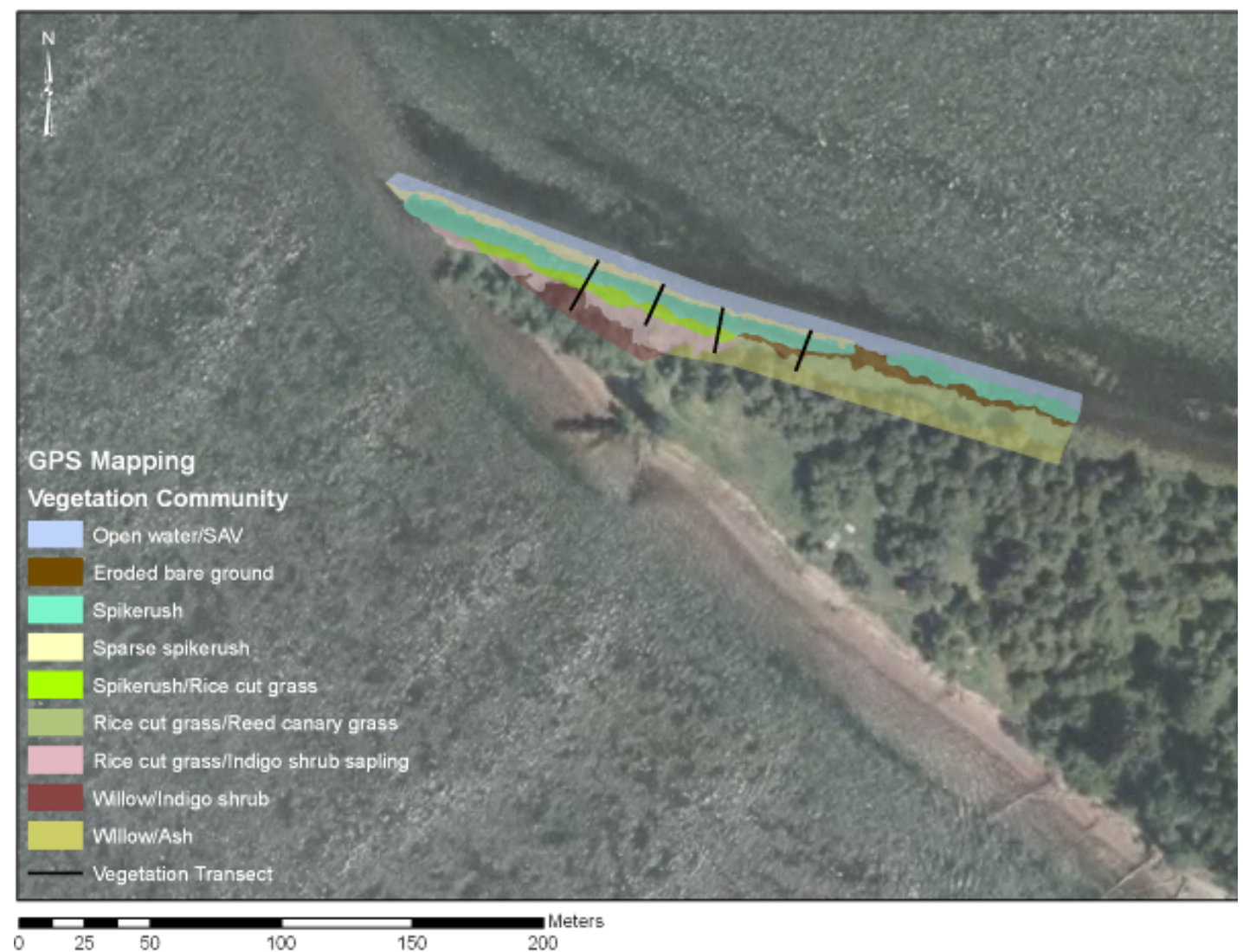

Figure 16. Vegetation Map for Site A, Reed Island. Transects for \% cover estimates are in black. 
Site B

Chatham Island

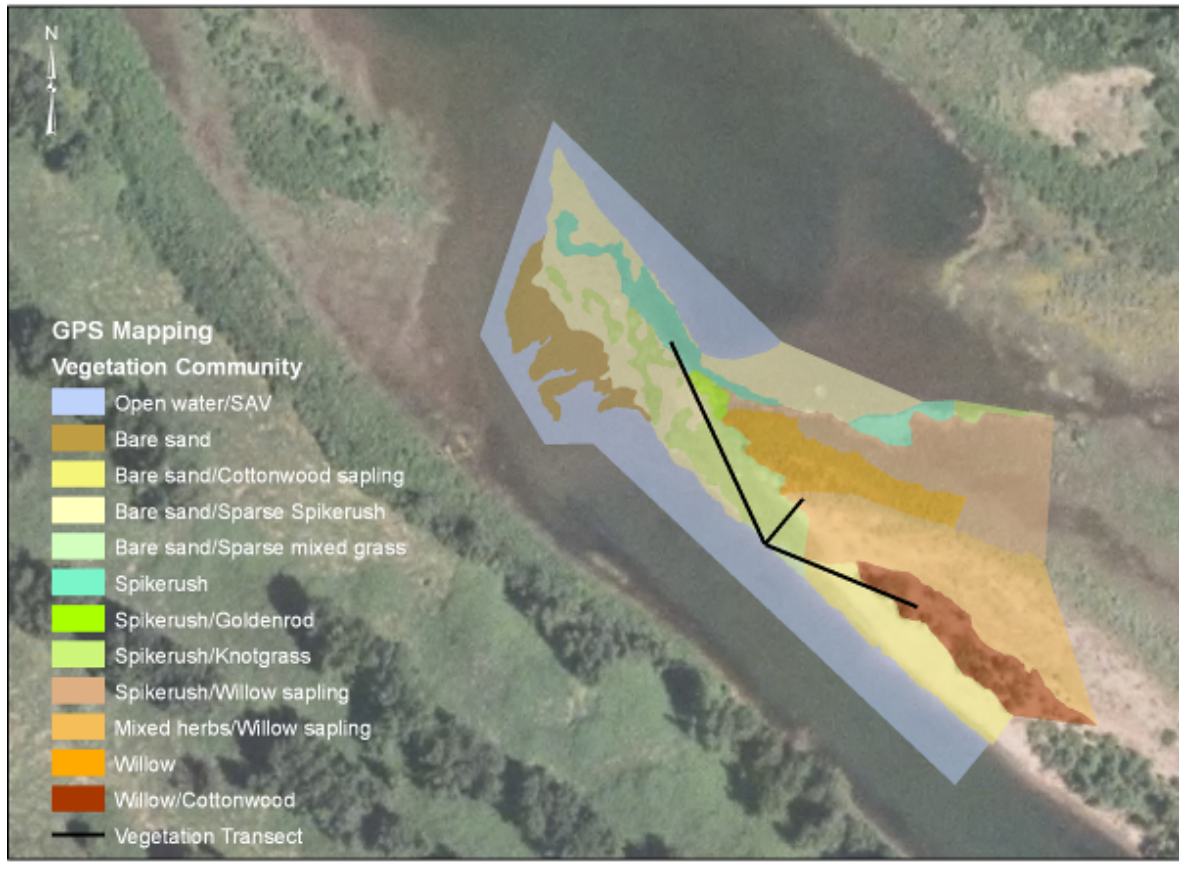

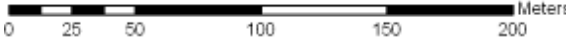

Figure 17. Vegetation Map for Site B, Chatham Island. Transects for \% cover estimates are in black.

Site C

Old Sandy River Mouth

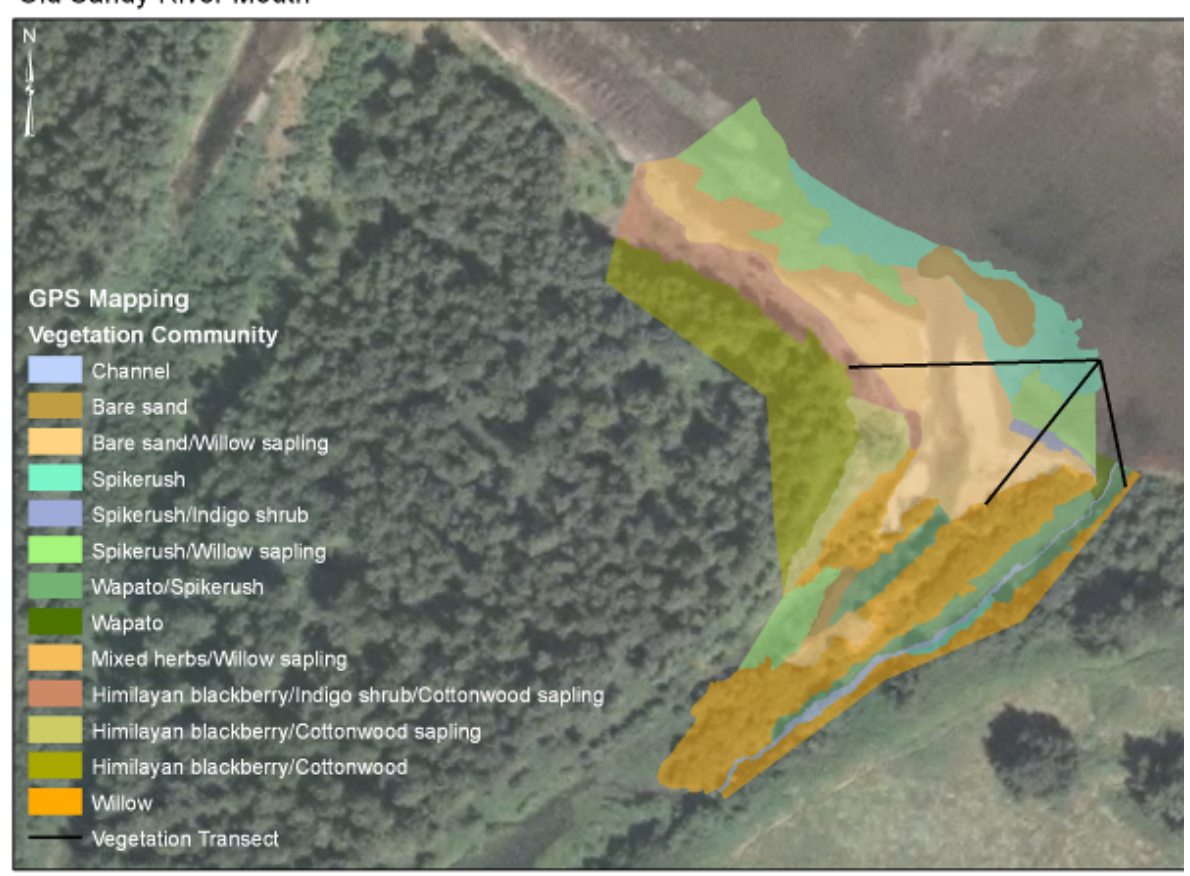

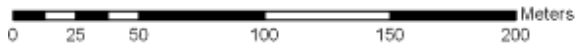

Figure 18. Vegetation Map for Site C, Old Sandy. Transects for \% cover estimates are in black. 

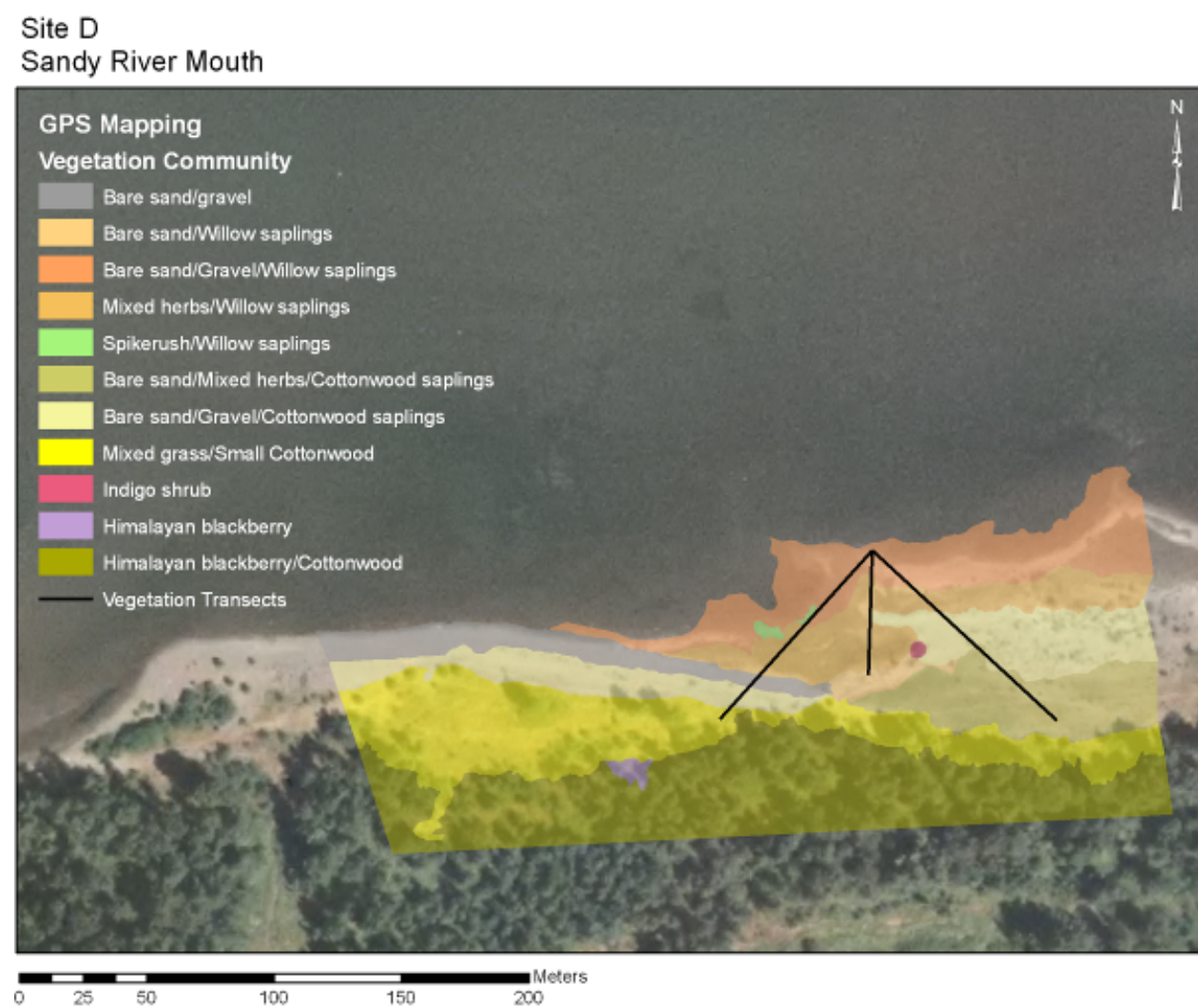

Figure 19 Vegetation Map for Site D, Sandy River. Transects for \% cover estimates are in black.
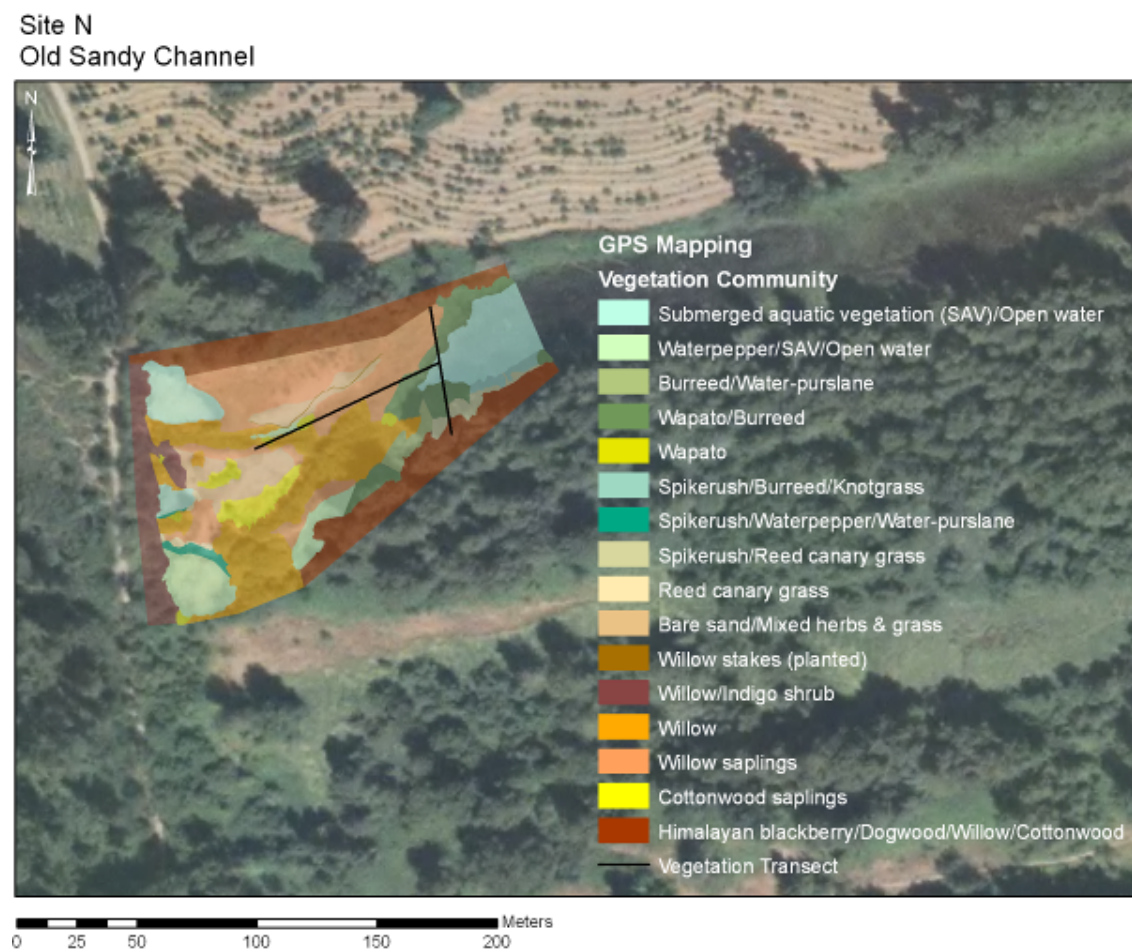

\section{GPS Mapping}

Vegetation Community

Submerged aquatic vegetation (SAV)/Open water Wapato/Burreed

Spikerush/BurreediKnotgrass Spikerush/Waterpepper/Water-pursla Willow

Figure 20. Vegetation map for Site N, Old Sandy. Transects for \% cover estimates are in black. 


\section{Site E \\ Gary Island}

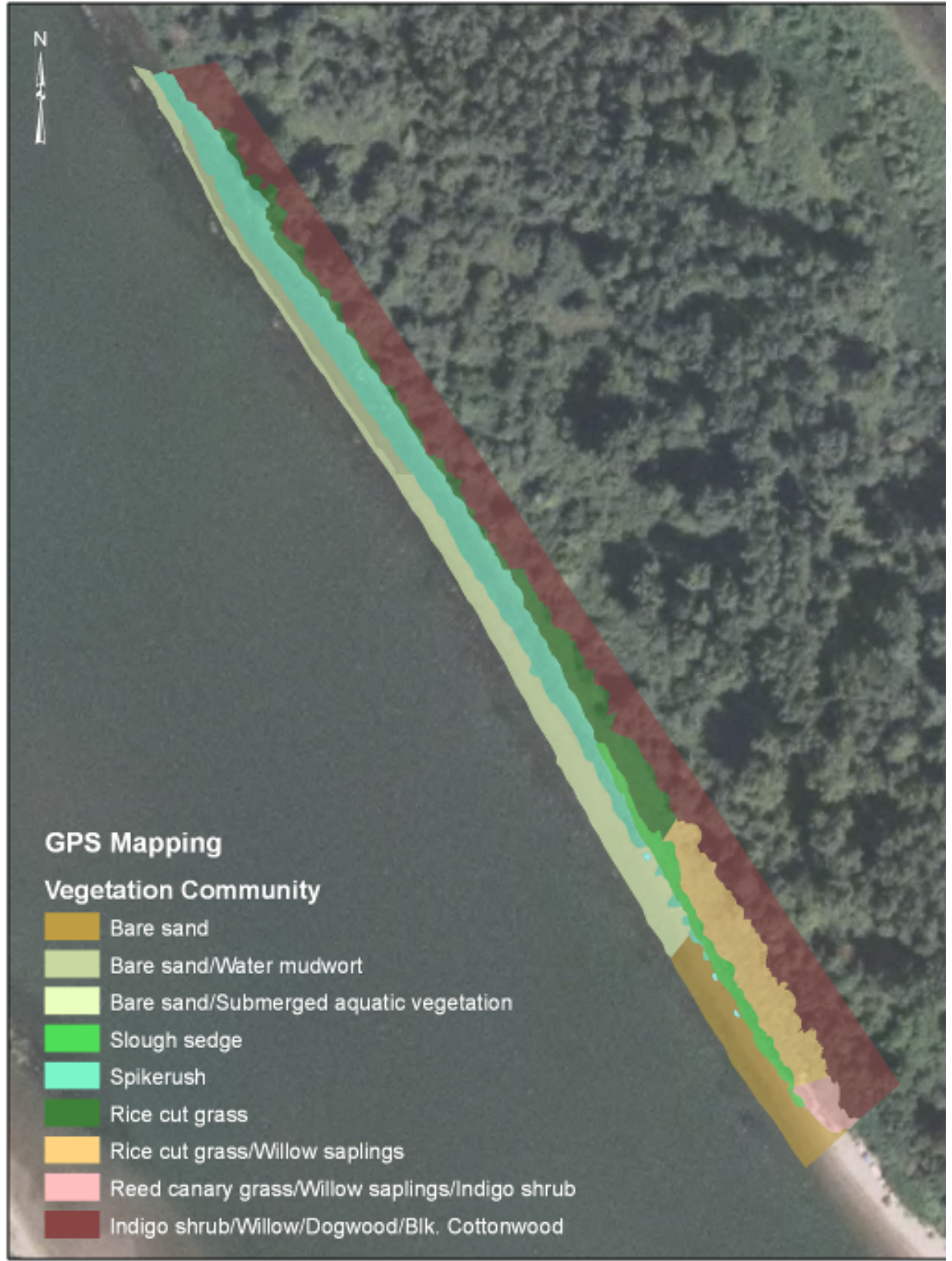

Meters

$\begin{array}{llll}25 & 50 & 100 & 150\end{array}$

Figure 21. Vegetation map for Site E, Gary Island. No vegetation transects for percent cover were collected at Gary Island because the site was added after the survey occurred. 


\subsubsection{Elevation}

Elevation, which is directly tied to hydrology and topography is an important determinate for plant growth. To better understand plant elevation strata at each site, we collected high-precision elevation data at points in the vegetation quadrats. Obtaining measurements near the riparian border was difficult due to satellite positioning, therefore in some cases these data were omitted from the analysis.

Some plants, like the highly invasive reed canary grass (PHAR), have a wide range of elevation tolerance (Figure 22) while others, like water mudwart (Limosella aquatica, LIAQ) grow in a more narrow range.

\subsubsection{Similarity}

Sites B and C were most similar to each other, with a similarity of over $70 \%$. Sites N and D were the least similar to each other, with only $32 \%$ similarity between species. The other sites fell in the middle, with Sites C and D being above 60\%. All comparisons between Site C and others were more than $50 \%$ similar. Site $\mathrm{N}$ was the least like the other sites with two values below $50 \%$ and two values just above $50 \%$ (Table 7).

Table 7. Percent similarity using index between sites in the study.

\begin{tabular}{cccccc}
\hline Site & A & B & C & D & N \\
\hline A & & & & & \\
B & 57.69 & & & & \\
C & 58.62 & 70.58 & & & \\
D & 42.55 & 49.12 & 60.31 & & \\
N & 46.15 & 57.14 & 54.54 & 31.81 & \\
\hline
\end{tabular}




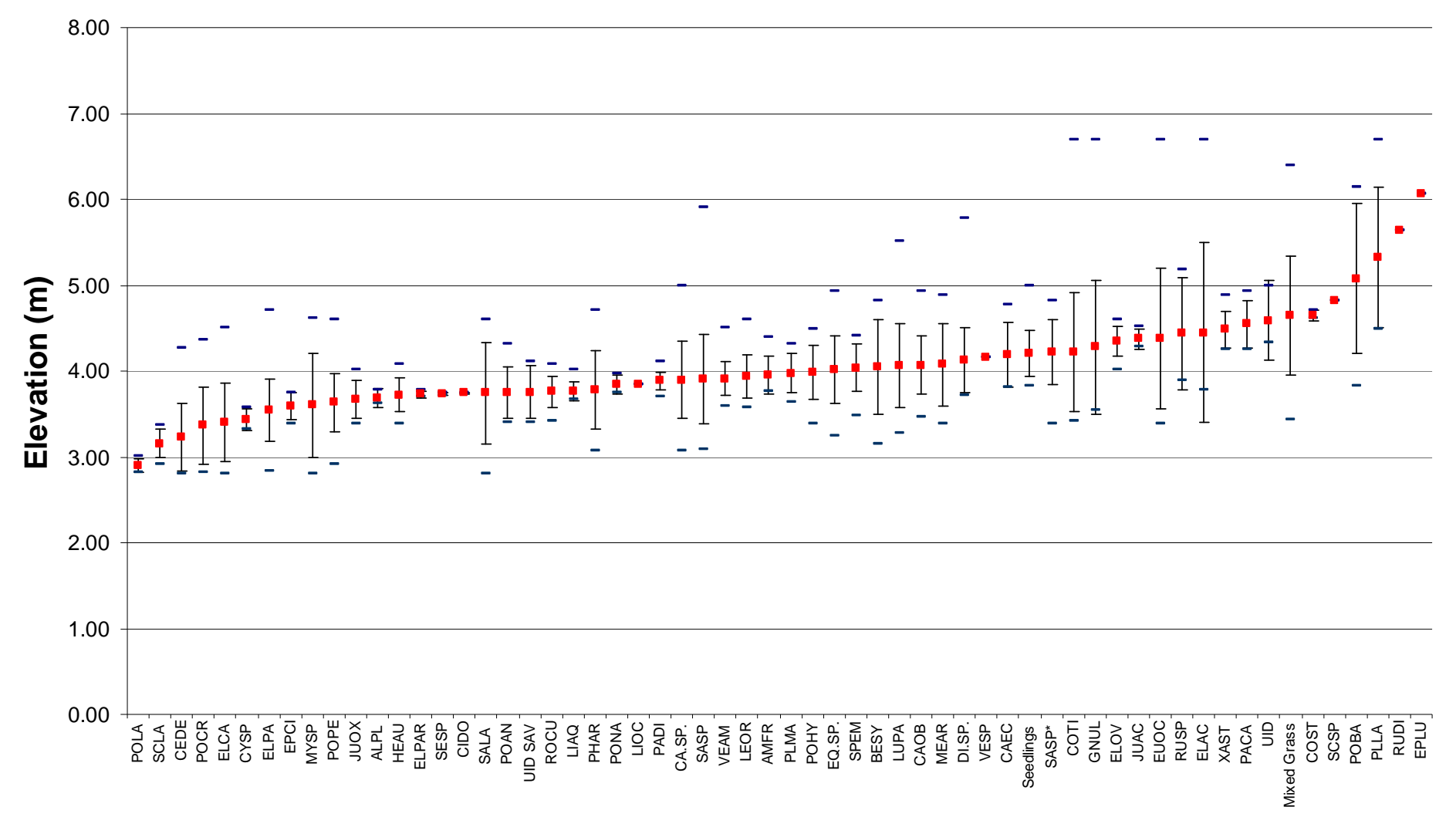

Plant Species

- Min - Max - Mean

Figure 22. Plant Species and Elevations. Observed in the field at all sites combined. Error bars indicate one standard deviation from the mean. 


\subsection{Fish Community Characteristics}

\subsubsection{Catch}

General. Our 2007 sampling effort yielded a total catch of 17,428 individual fish. Taxonomic categories included 23 different species and seven genera (Figure 23). The most dominant species were threespine stickleback (Gasterosteus aculeatus), banded killifish (Fundulus diaphanous), peamouth (Mylocheilus caurinus), northern pikeminnow (Ptychocheilus oregonensis), and bluegill (Lepomis macrochirus). These dominant species were present in beach seine catches during all months of the study period and were also found at each of the six sampling locations (Tables 8 and 9).

Fish species comprising less than $4 \%$ of the total catch present during all months of the study include a total of over 20 species, including sculpin (Cottus spp.), largemouth bass (Micropterus salmoides), and Chinook salmon. Sculpin and largemouth bass also occurred at all sites (Table 8). While not a large portion of our catch, we captured three Amur gobies (Rhinogobius brunneus) at Site $\mathrm{N}$. This species is of concern because it is a recently introduced species and its potential impacts are not well understood. Many (40\%) of the species we collected are not native to the Columbia River.

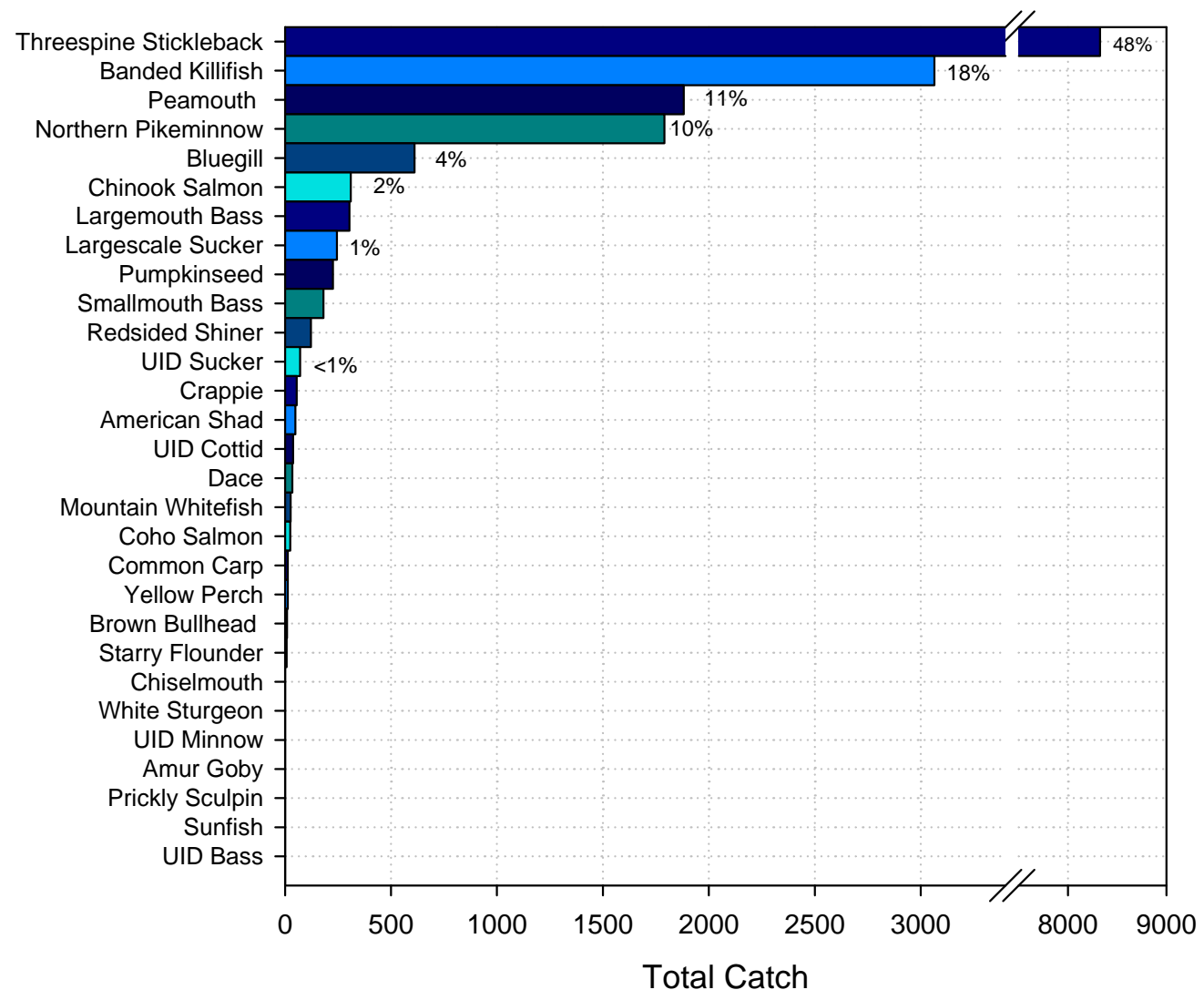

Figure 23. Total Combined Catch at all Sites throughout the 2007 Sampling Season. Percentages are calculated as the fraction of the individual species to the total catch. 
Table 8. Temporal Trends in Species Composition. X denotes species collected during the sampling period.

\begin{tabular}{|c|c|c|c|c|c|c|c|c|c|}
\hline Latin Name & Common Name & June $^{\mathrm{a}}$ & June $^{\mathrm{b}}$ & July & August & September & October & November & December \\
\hline Cottus spp. & UID Cottid & $\mathrm{x}$ & $\mathrm{X}$ & $\mathrm{x}$ & $\mathrm{x}$ & $\mathrm{x}$ & $\mathrm{x}$ & $\mathrm{x}$ & $\mathrm{x}$ \\
\hline Fundulus diaphanus & Banded Killifish $^{c}$ & $\mathrm{x}$ & $\mathrm{x}$ & $\mathrm{x}$ & $\mathrm{x}$ & $\mathrm{x}$ & $\mathrm{x}$ & $\mathrm{x}$ & $\mathrm{x}$ \\
\hline Gasterosteus aculeatus & Threespine Stickleback & $\mathrm{x}$ & $\mathrm{x}$ & $\mathrm{x}$ & $\mathrm{x}$ & $\mathrm{x}$ & $\mathrm{x}$ & $\mathrm{x}$ & $\mathrm{x}$ \\
\hline Lepomis macrochirus & Bluegill $^{\mathrm{C}}$ & $\mathrm{x}$ & $\mathrm{x}$ & $\mathrm{x}$ & $\mathrm{x}$ & $\mathrm{x}$ & $\mathrm{x}$ & $\mathrm{x}$ & $\mathrm{x}$ \\
\hline Micropterus salmoides & Largemouth Bass $^{\mathrm{c}}$ & $\mathrm{x}$ & $\mathrm{x}$ & $\mathrm{x}$ & $\mathrm{x}$ & $\mathrm{x}$ & $\mathrm{x}$ & $\mathrm{x}$ & $\mathrm{x}$ \\
\hline Mylocheilus caurinus & Peamouth & $\mathrm{x}$ & $\mathrm{x}$ & $\mathrm{x}$ & $\mathrm{x}$ & $\mathrm{x}$ & $\mathrm{x}$ & $\mathrm{x}$ & $\mathrm{x}$ \\
\hline Ptychocheilus oregonensis & Northern Pikeminnow & $\mathrm{x}$ & $\mathrm{x}$ & $\mathrm{x}$ & $\mathrm{x}$ & $\mathrm{x}$ & $\mathrm{x}$ & $\mathrm{x}$ & $\mathrm{x}$ \\
\hline Lepomis gibbosus & Pumpkinseed $^{\mathrm{C}}$ & $\mathrm{x}$ & & $\mathrm{x}$ & $\mathrm{x}$ & $\mathrm{x}$ & $\mathrm{x}$ & $\mathrm{x}$ & $\mathrm{x}$ \\
\hline Catostomus spp. & UID Sucker & $\mathrm{x}$ & $\mathrm{x}$ & & $\mathrm{x}$ & & $\mathrm{x}$ & $\mathrm{x}$ & $\mathrm{x}$ \\
\hline Micropterus dolomieu & Smallmouth Bass ${ }^{c}$ & $\mathrm{x}$ & & $\mathrm{x}$ & $\mathrm{x}$ & $\mathrm{x}$ & & $\mathrm{x}$ & $\mathrm{x}$ \\
\hline Oncorhynchus tshawytscha & Chinook Salmon $(0+)$ & $\mathrm{x}$ & $\mathrm{x}$ & $\mathrm{x}$ & $\mathrm{x}$ & & & $\mathrm{x}$ & $\mathrm{x}$ \\
\hline Catostomus macrocheilus & Largescale Sucker & $\mathrm{x}$ & $\mathrm{x}$ & $\mathrm{x}$ & $\mathrm{x}$ & $\mathrm{x}$ & & & \\
\hline Pomoxis spp. & Crappie $^{c}$ & & & $\mathrm{x}$ & $\mathrm{x}$ & $\mathrm{x}$ & $\mathrm{x}$ & $\mathrm{x}$ & \\
\hline Alosa sapidissima & American Shad ${ }^{\mathrm{c}}$ & & & & $\mathrm{x}$ & $\mathrm{x}$ & $\mathrm{x}$ & $\mathrm{x}$ & \\
\hline Cyprinus carpio & Common Carp ${ }^{c}$ & & & $\mathrm{x}$ & $\mathrm{x}$ & $\mathrm{x}$ & & & \\
\hline Oncorhynchus kisutch & Coho Salmon & $\mathrm{x}$ & & & & & & $\mathrm{x}$ & $\mathrm{x}$ \\
\hline Platichthys stellatus & Starry Flounder & $\mathrm{x}$ & $\mathrm{X}$ & & & & & & $\mathrm{x}$ \\
\hline Rhinichthys spp. & Dace & $\mathrm{X}$ & & & & & & $\mathrm{x}$ & $\mathrm{x}$ \\
\hline Ameiurus nebulosus & Brown Bullhead $^{\mathrm{c}}$ & & & & & $\mathrm{x}$ & & $\mathrm{x}$ & \\
\hline Prosopium williamsoni & Mountain Whitefish & $\mathrm{x}$ & & & & & & $\mathrm{x}$ & \\
\hline Rhinogobius brunneus & Amur Goby ${ }^{c}$ & & $\mathrm{x}$ & & & & $\mathrm{x}$ & & \\
\hline Richardsonius balteatus & Redside Shiner & $\mathrm{x}$ & $\mathrm{x}$ & & & & & & \\
\hline Acipenser transmontanus & White Sturgeon & $\mathrm{x}$ & & & & & & & \\
\hline Acrocheilus alutaceus & Chiselmouth & $\mathrm{x}$ & & & & & & & \\
\hline Cottus asper & Prickly Sculpin & $\mathrm{x}$ & & & & & & & \\
\hline Cyprinidae spp. & UID Minnow & & & & & & & $\mathrm{x}$ & \\
\hline Lepomis cyanellus & Green Sunfish $^{\mathrm{c}}$ & & & $\mathrm{x}$ & & & & & \\
\hline Micropterus spp. & UID Bass $^{\mathrm{c}}$ & & & $\mathrm{x}$ & & & & & \\
\hline Perca flavescens & Yellow Perch ${ }^{\mathrm{c}}$ & & & & & & & $\mathrm{x}$ & $\mathrm{x}$ \\
\hline
\end{tabular}

${ }^{\mathrm{a}}$ Initial sampling began on June 5th and June 6th, 2007

${ }^{\mathrm{b}}$ An additional sampling effort was made on June 26 and 27th, 2007

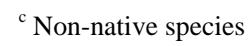


Table 9. Spatial Trends in Species Composition

\begin{tabular}{|c|c|c|c|c|c|c|c|}
\hline Latin Name & Common Name & A & $\mathrm{B}$ & $\mathrm{C}$ & $\mathrm{D}$ & E & $\mathrm{N}$ \\
\hline Fundulus diaphanus & Banded Killifish & $\mathrm{x}$ & $\mathrm{x}$ & $\mathrm{x}$ & $\mathrm{x}$ & $\mathrm{x}$ & $\mathrm{x}$ \\
\hline Gasterosteus aculeatus & Threespine Stickleback & $\mathrm{x}$ & $\mathrm{x}$ & $\mathrm{x}$ & $\mathrm{x}$ & $\mathrm{x}$ & $\mathrm{x}$ \\
\hline Lepomis macrochirus & Bluegill & $\mathrm{x}$ & $\mathrm{x}$ & $\mathrm{x}$ & $\mathrm{x}$ & $\mathrm{x}$ & $\mathrm{x}$ \\
\hline Micropterus dolomieu & Smallmouth Bass & $\mathrm{x}$ & $\mathrm{x}$ & $\mathrm{x}$ & $\mathrm{x}$ & $\mathrm{x}$ & $\mathrm{x}$ \\
\hline Micropterus salmoides & Largemouth Bass & $\mathrm{x}$ & $\mathrm{x}$ & $\mathrm{x}$ & $\mathrm{x}$ & $\mathrm{x}$ & $\mathrm{x}$ \\
\hline Mylocheilus caurinus & Peamouth & $\mathrm{x}$ & $\mathrm{x}$ & $\mathrm{x}$ & $\mathrm{x}$ & $\mathrm{x}$ & $\mathrm{x}$ \\
\hline Oncorhynchus tshawytscha & Chinook Salmon $(0+)$ & $\mathrm{x}$ & $\mathrm{x}$ & $\mathrm{x}$ & $\mathrm{x}$ & $\mathrm{x}$ & $\mathrm{x}$ \\
\hline Ptychocheilus oregonensis & Northern Pikeminnow & $\mathrm{x}$ & $\mathrm{x}$ & $\mathrm{x}$ & $\mathrm{x}$ & $\mathrm{x}$ & $\mathrm{x}$ \\
\hline Catostomus macrocheilus & Largescale Sucker & $\mathrm{x}$ & $\mathrm{x}$ & $\mathrm{x}$ & $\mathrm{x}$ & & $\mathrm{x}$ \\
\hline Cottus spp. & UID Cottid & $\mathrm{x}$ & $\mathrm{x}$ & $\mathrm{x}$ & & $\mathrm{x}$ & $\mathrm{x}$ \\
\hline Alosa sapidissima & American Shad & $\mathrm{x}$ & $\mathrm{x}$ & & $\mathrm{x}$ & $\mathrm{x}$ & \\
\hline Catostomus spp. & UID Sucker & & $\mathrm{x}$ & $\mathrm{x}$ & $\mathrm{x}$ & & $\mathrm{x}$ \\
\hline Oncorhynchus kisutch & Coho Salmon & & $\mathrm{x}$ & $\mathrm{x}$ & & $\mathrm{x}$ & $\mathrm{x}$ \\
\hline Platichthys stellatus & Starry Flounder & $\mathrm{x}$ & $\mathrm{x}$ & $\mathrm{x}$ & $\mathrm{x}$ & & \\
\hline Rhinichthys spp. & Dace & & $\mathrm{x}$ & $\mathrm{x}$ & & $\mathrm{x}$ & $\mathrm{x}$ \\
\hline Ameiurus nebulosus & Brown Bullhead & & $\mathrm{x}$ & $\mathrm{x}$ & & & $\mathrm{x}$ \\
\hline Cyprinus carpio & Common Carp & & $\mathrm{x}$ & $\mathrm{x}$ & & & $\mathrm{x}$ \\
\hline Prosopium williamsoni & Mountain Whitefish & $\mathrm{x}$ & $\mathrm{x}$ & & $\mathrm{x}$ & & \\
\hline Richardsonius balteatus & Redside Shiner & & $\mathrm{x}$ & $\mathrm{x}$ & $\mathrm{x}$ & & \\
\hline Acrocheilus alutaceus & Chiselmouth & & & & $\mathrm{x}$ & & $\mathrm{x}$ \\
\hline Cyprinidae spp. & UID Minnow & & & $\mathrm{x}$ & $\mathrm{x}$ & & \\
\hline Lepomis gibbosus & Pumpkinseed & & $\mathrm{x}$ & & & & $\mathrm{x}$ \\
\hline Perca flavescens & Yellow Perch & & $\mathrm{x}$ & $\mathrm{x}$ & & & \\
\hline Pomoxis spp. & Crappie & & $\mathrm{x}$ & & & & $\mathrm{x}$ \\
\hline Acipenser transmontanus & White Sturgeon & & & & $\mathrm{x}$ & & \\
\hline Cottus asper & Prickly Sculpin & & & & $\mathrm{x}$ & & \\
\hline Lepomis cyanellus & Green Sunfish & & & $\mathrm{x}$ & & & \\
\hline Micropterus spp. & UID Bass & & & $\mathrm{x}$ & & & \\
\hline Rhinogobius brunneus & Amur Goby & & & & & & $\mathrm{x}$ \\
\hline
\end{tabular}

Ubiquitous Species. The five most dominant species (bluegill, banded killifish, northern pikeminnow, peamouth, threespine stickleback) were encountered at each of the six sampling locations throughout the sampling effort (Tables 8 and 9). Seasonal peak abundances varied by species and site. Comprising approximately $4 \%$ of the total catch, bluegill were most prevalent at Sites $\mathrm{N}$ and $\mathrm{B}$ with peak catches occurring after October. Peamouth chub were most dominant at Sites A, B, and D. Sites C and B yielded some of the largest catches of northern pikeminnow. Peak abundance for banded killifish and threespine stickleback peaked in December at Site C, however this trend did not occur at other sites. Site summaries for the five most prevalent species encountered during our study are presented in Figure 24. 


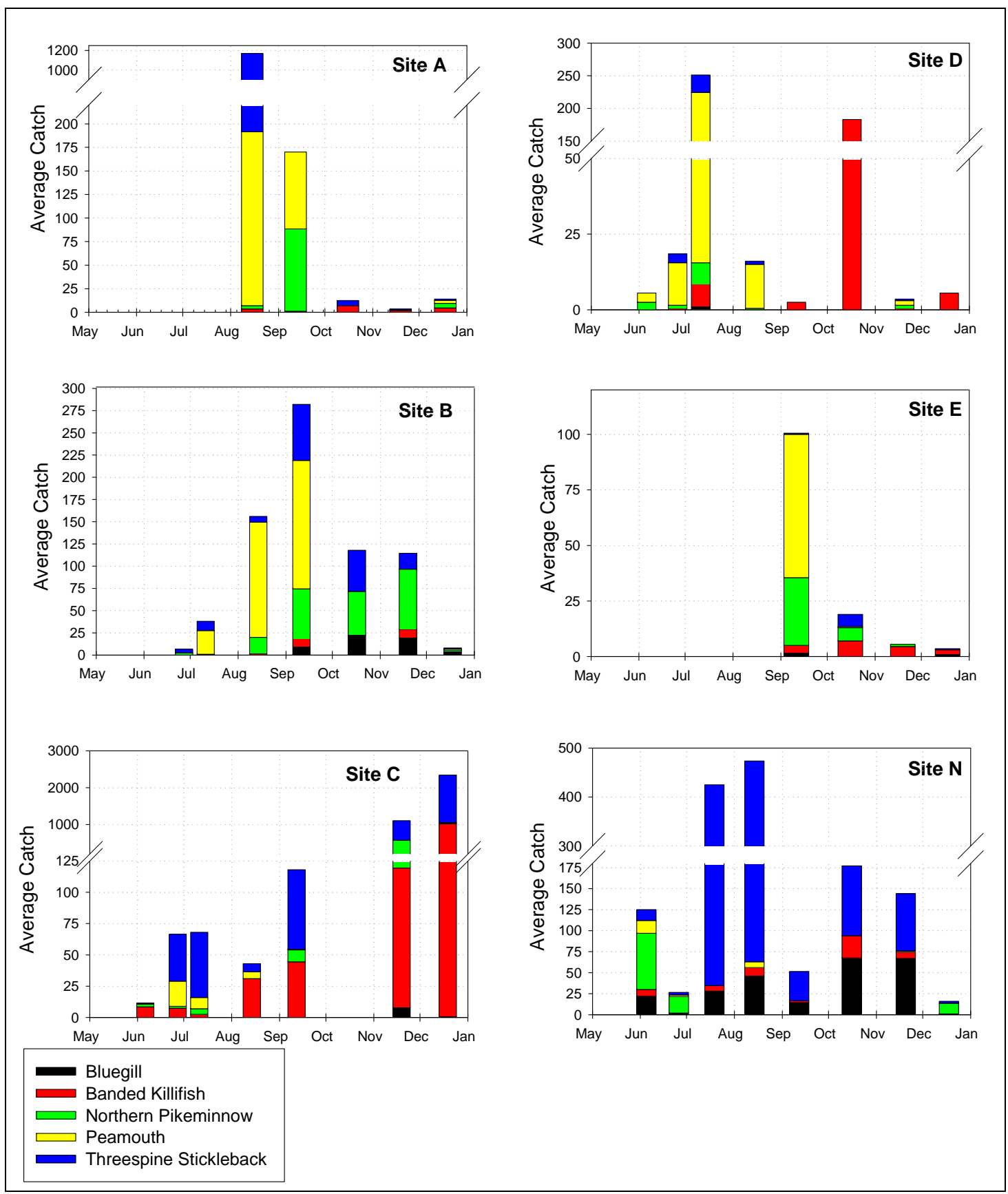

Figure 24. Temporal Distribution of the Average Catch for the Five Most Dominant Species. Note:

$\mathrm{Y}$-axis scale varies for greater resolution.

Length-frequency distributions of the most dominant fish sampled during our study indicate a range of species life stages present in the shallow habitats near the Sandy River delta. Size ranges for threespine stickleback, banded killifish, and bluegill likely represent juvenile to adult stage fish (Wydoski and Whitney 2003). Length frequency distributions for peamouth and northern pikeminnow show peaks at the juvenile stages, but likely include some larger sized sub-adult or adult fish (Figure 25). 

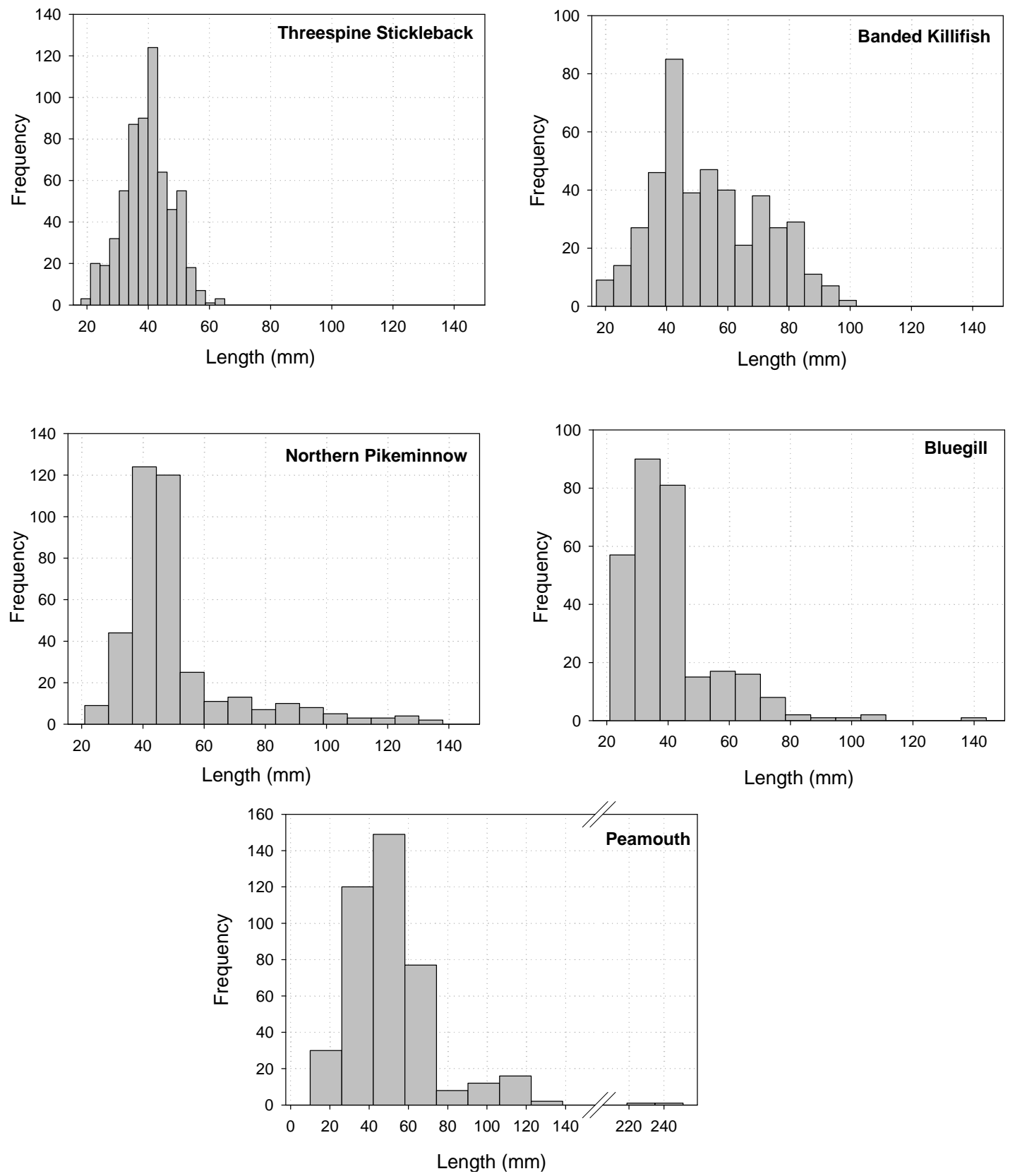

Figure 25. Length Frequency Distribution for the Five Most Abundant Species Captured. Length is total length for Threespine Stickleback, Banded Killifish, and Bluegill and fork length for Peamouth and Northern Pikeminnow. 
Salmonids. Salmon catches were comprised of nominally wild (unmarked) Chinook and coho salmon and a very small portion of hatchery Chinook salmon, identified by clipped adipose fins and/or coded wire tags (CWT). Chum salmon, steelhead, and cutthroat trout were not captured at any of the sampling sites. Chinook salmon were found at each of the six sampling sites at various times throughout the sampling season. Coho salmon were encountered at all sites except A, and compared to Chinook salmon, occurred less frequently during our study period. Coho salmon catches increased during November and December (Figure 26). Average catches for Chinook salmon were highest during June at Sites B, C, and D after which catches at all sites subsided until November and December when, at Site E, appreciable numbers of Chinook salmon were caught (Figure 26).
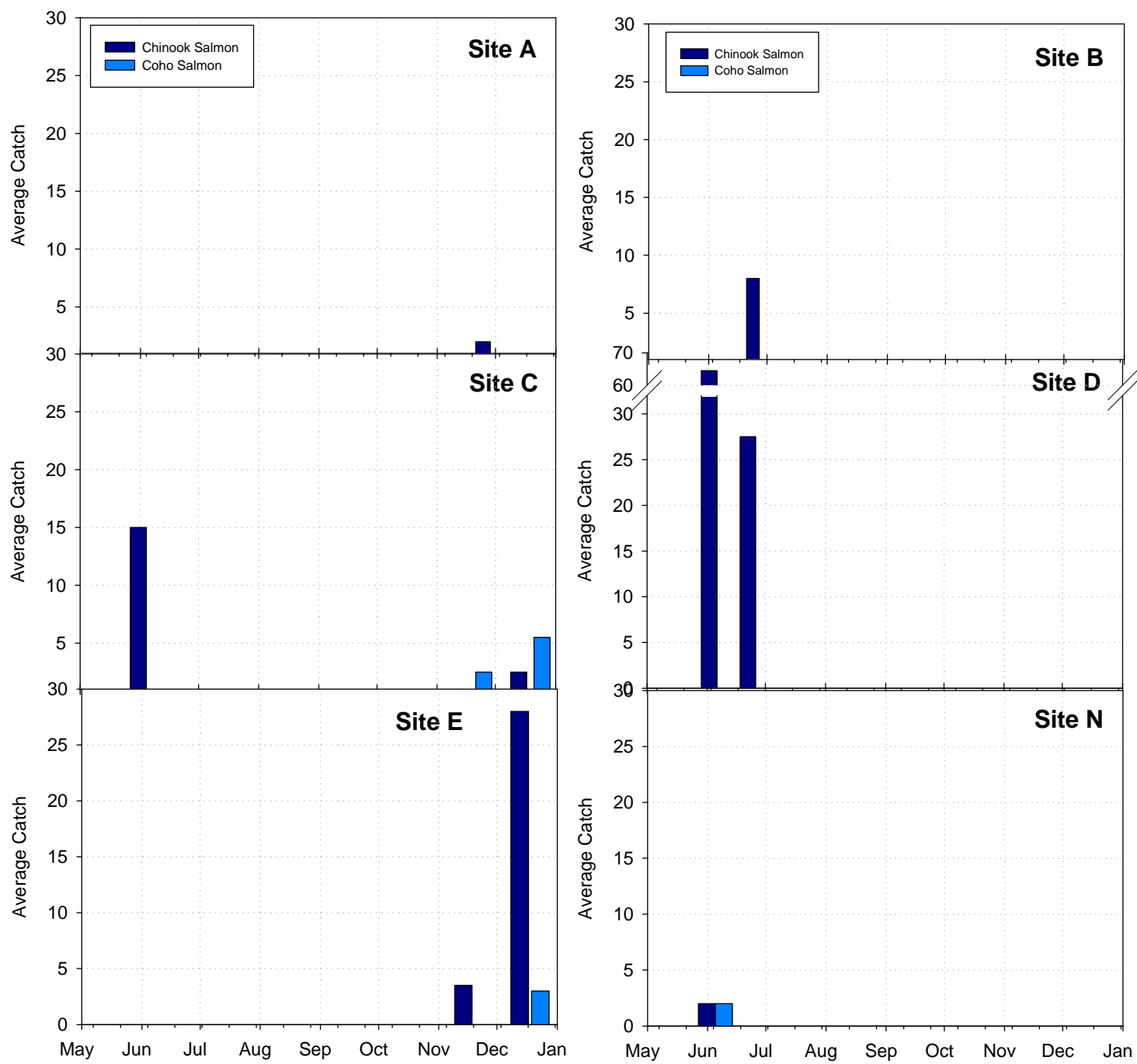

Figure 26. Temporal Distribution of Average Catch of Chinook and Coho Salmon by Site. Note different Y-Axis scale for Site D. 
Size of Chinook and coho salmon sampled during our study ranged from approximately 45 to120 mm FL, with subyearlings being predominant. The size distributions of Chinook salmon at sites B, C, and D were relatively similar; approximately 50-90 mm FL. A shift toward larger lengths for Chinook salmon occurred at site $\mathrm{E}$ late in the year (Figure 27). Coho salmon occurred less frequently in our catches than Chinook salmon, and ranged between 65-155 mm FL. The size distributions for coho salmon were similar among sites and, as with Chinook salmon, larger sized coho salmon were captured at site E (Figure 28, a high proportion of these were captured late in the year). Seasonal size differences in coho salmon are difficult to assess due in part to our truncated sampling season (JuneDecember), and to the relative absence of coho salmon in seine samples until November and December (Figure 29). While the mean fork length of Chinook salmon measured in December was larger than that of the mean from June, variation within the data does not provide definitive evidence for a significant difference in size between the two dates (Figure 30).
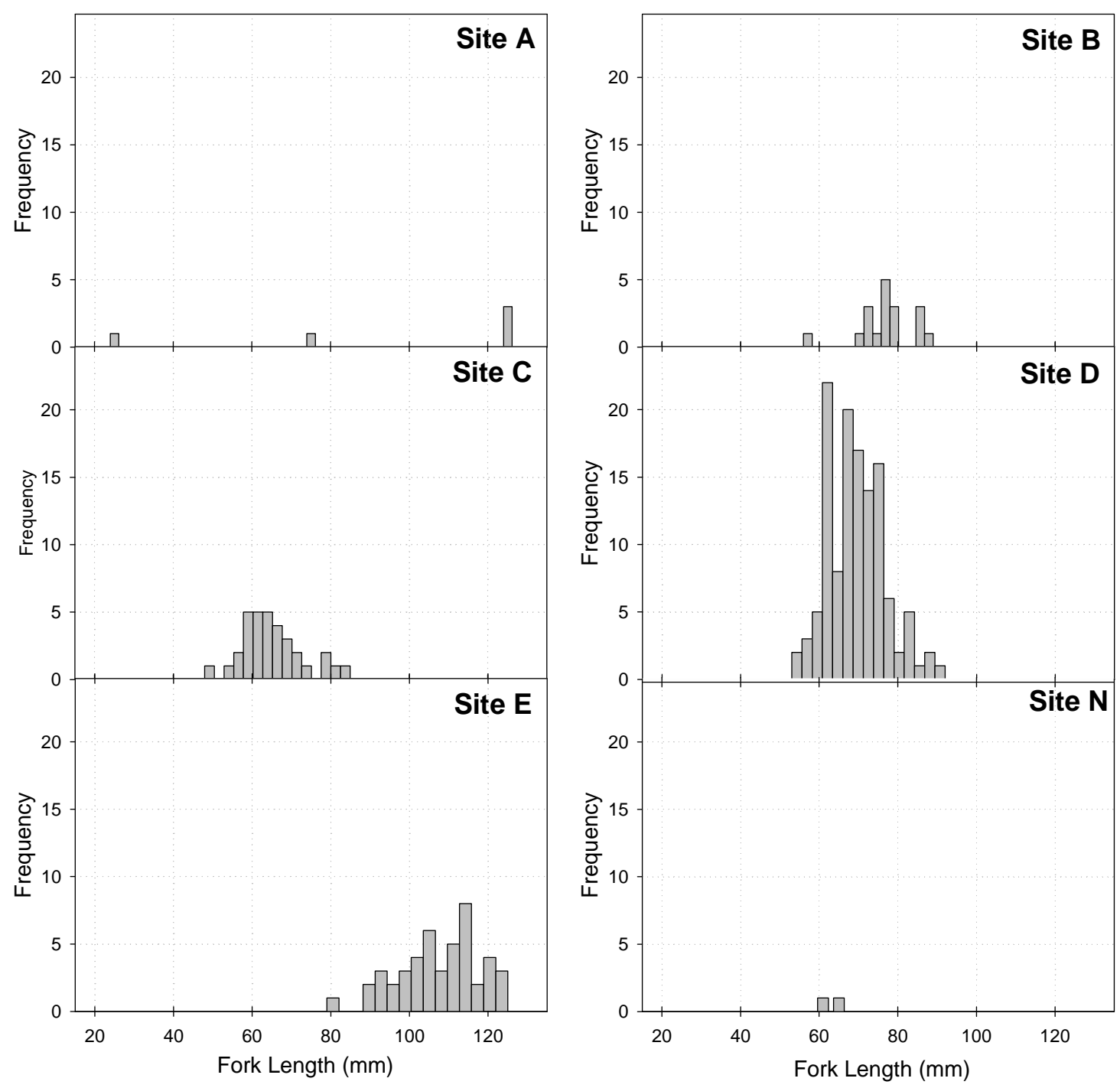

Figure 27. Length Frequency Distribution by Site for Chinook Salmon 


\section{Coho}
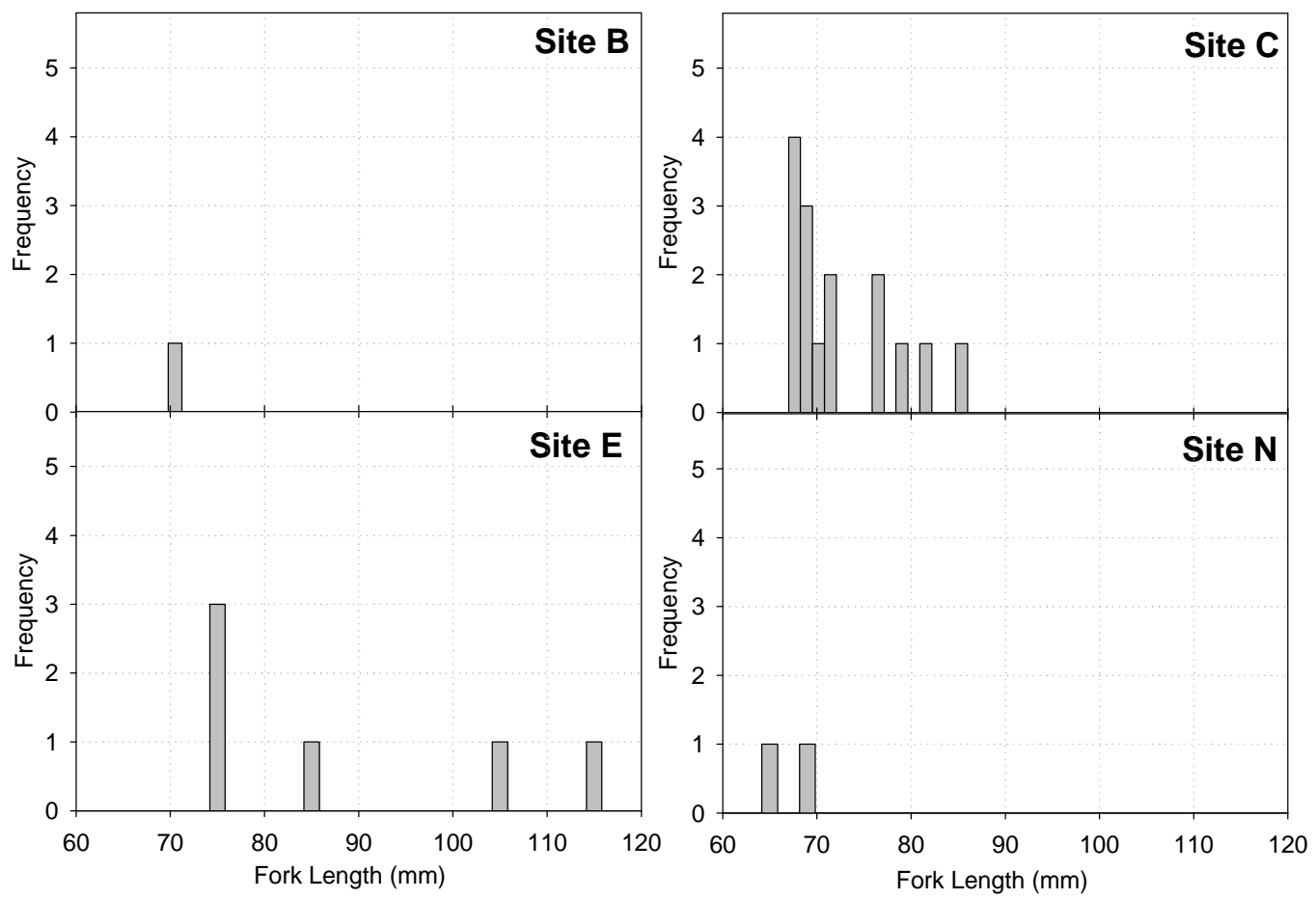

Figure 28. Length Frequency Distribution by Site for Coho Salmon. Coho salmon were not captured at sites $\mathrm{A}$ and $\mathrm{D}$ therefore these sites are not displayed.
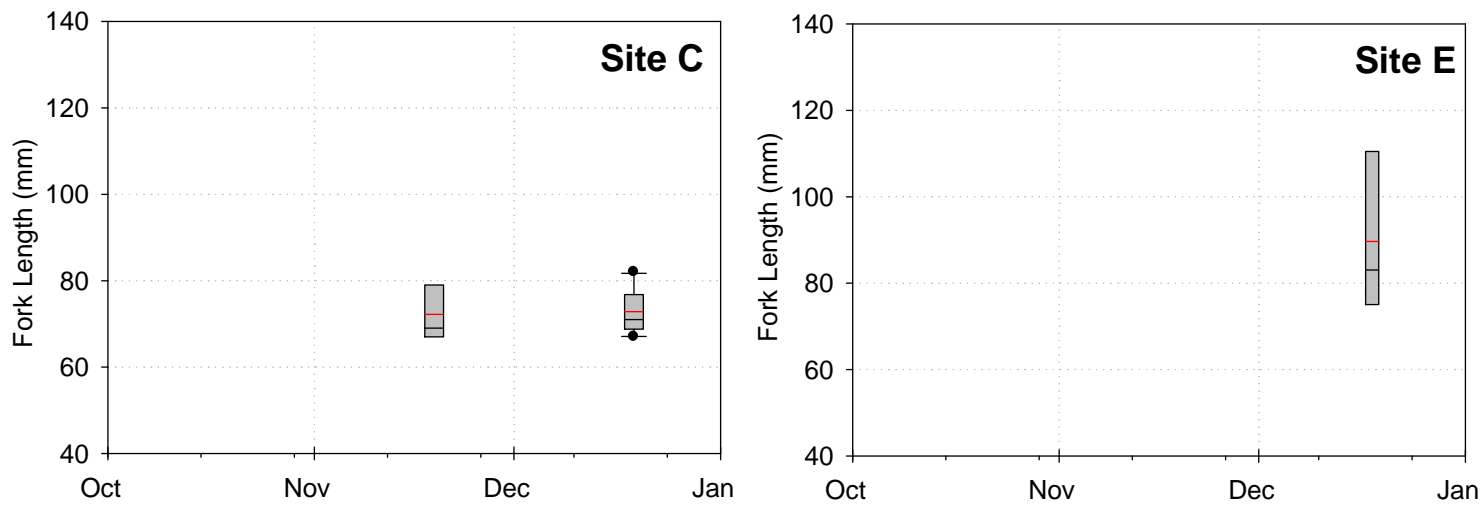

Figure 29. Spatial and Temporal Distributions of Coho Salmon Size during 2007. Box whiskers are the $90^{\text {th }}$ and $10^{\text {th }}$ percentiles. Whiskers are lacking from boxes when insufficient data exists for a given sampling period. The solid black line within the box indicates the median length while the red line denotes the sample mean. Solid black dots indicate sample outliers. Sites not displayed are due to either insufficient sample size, or the absence of coho salmon at a particular site (A and D). 

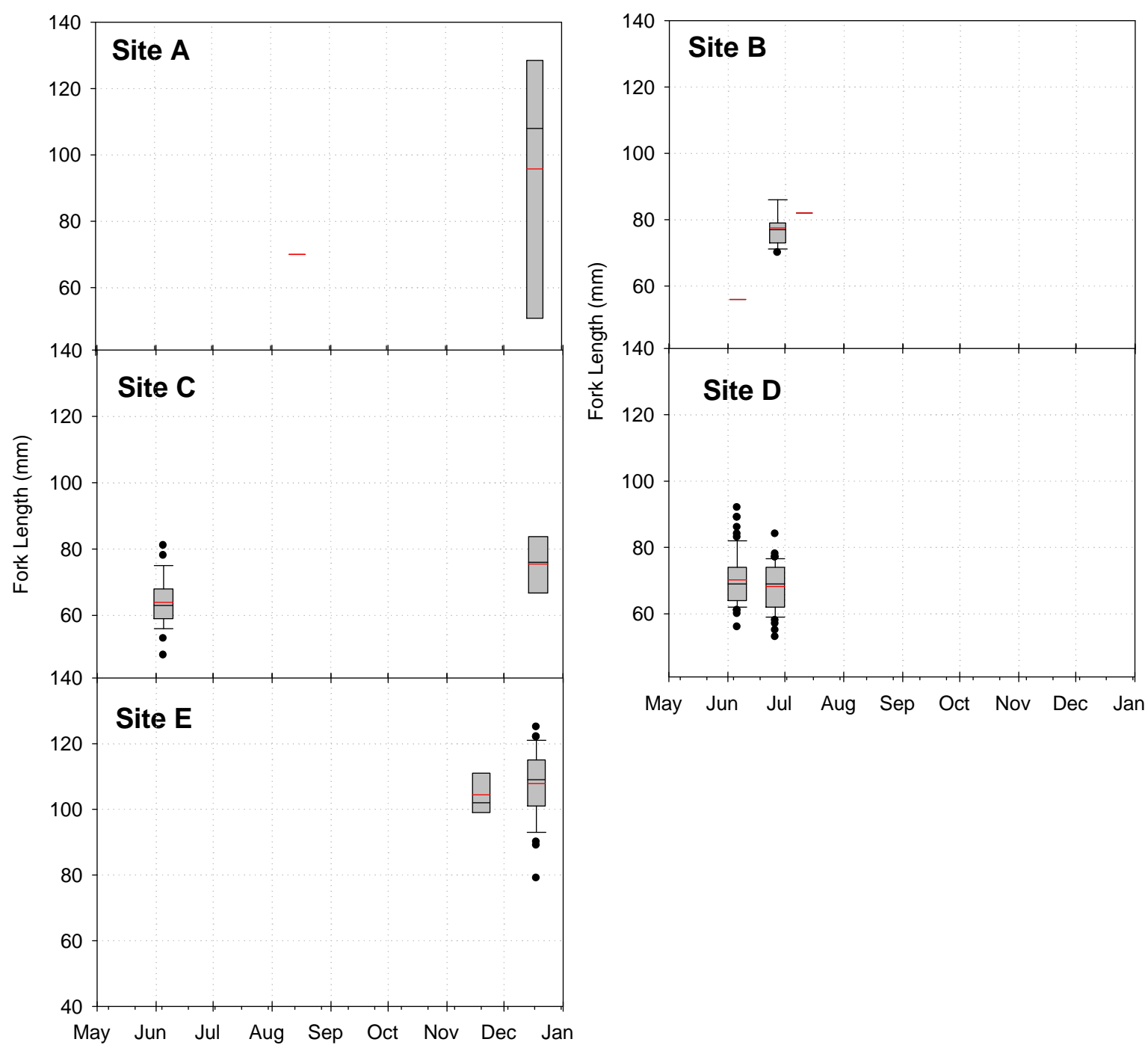

Figure 30. Spatial and Temporal Distributions of Chinook Salmon Size during 2007. Box whiskers are the $90^{\text {th }}$ and $10^{\text {th }}$ percentiles. Whiskers and/or boxes are lacking from boxes when insufficient data exists for a given sampling period. The solid black line within the box indicates the median length while the red line denotes the sample mean. Solid black dots indicate sample outliers. Site $\mathrm{N}$ is missing from this data set due to insufficient sample size. 


\subsubsection{Ancillary Data}

During each sampling trip we collected conventional water quality data (temperature, dissolved oxygen and salinity) at the time and location of the seine hauls. Temperature trends were similar at all sites, with a mid-summer (July/August) peak followed by a considerable decrease after the September sampling date (Figure 31). Site D had the warmest summer temperatures, likely due to the extensive shallows in the area of our sampling. The temperature at Site N remained the coolest of all sample sites during the summer.

Dissolved oxygen values were similar at most sites (Figure 32), remaining above $8 \mathrm{mg} / \mathrm{L}$ throughout the sampling period. Site B dipped to $7.3 \mathrm{mg} / \mathrm{L}$ in July, but returned to higher values in subsequent months. Site N showed an exception to the pattern, wherein dissolved oxygen was considerably lower than at the other sites, dropping to less than $2 \mathrm{mg} / \mathrm{L}$ in October. Dissolved oxygen values at this site were lower than most fish can tolerate, though catches during these low oxygen periods remained high.

Salinity data were collected as part of the water quality measurements. Reflective of the fresh water environment, salinity was $0.1 \mathrm{ppt}$ at all sites on all sampling dates.

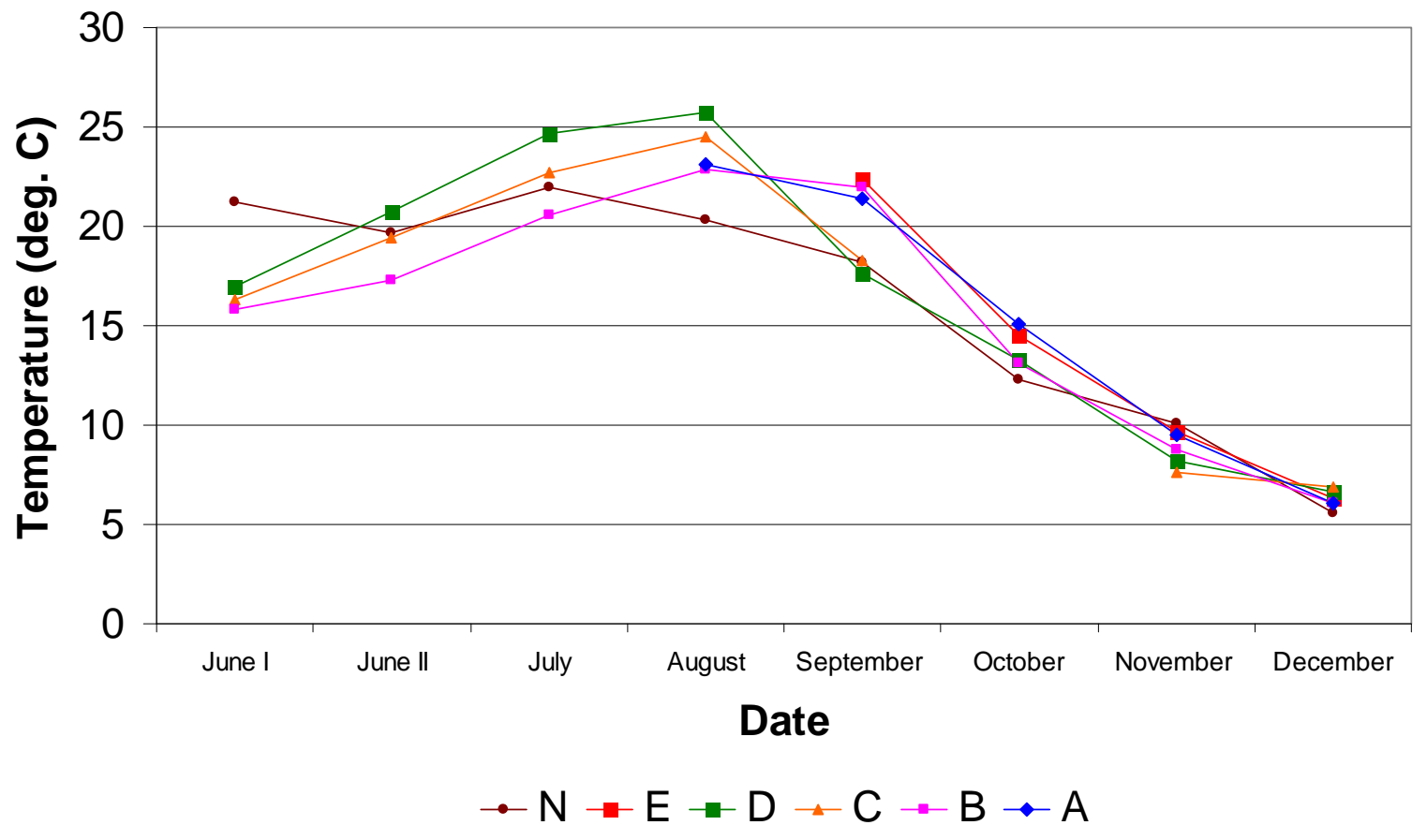

Figure 31. Temperature Data from Ancillary Measurements during Seining Events. 


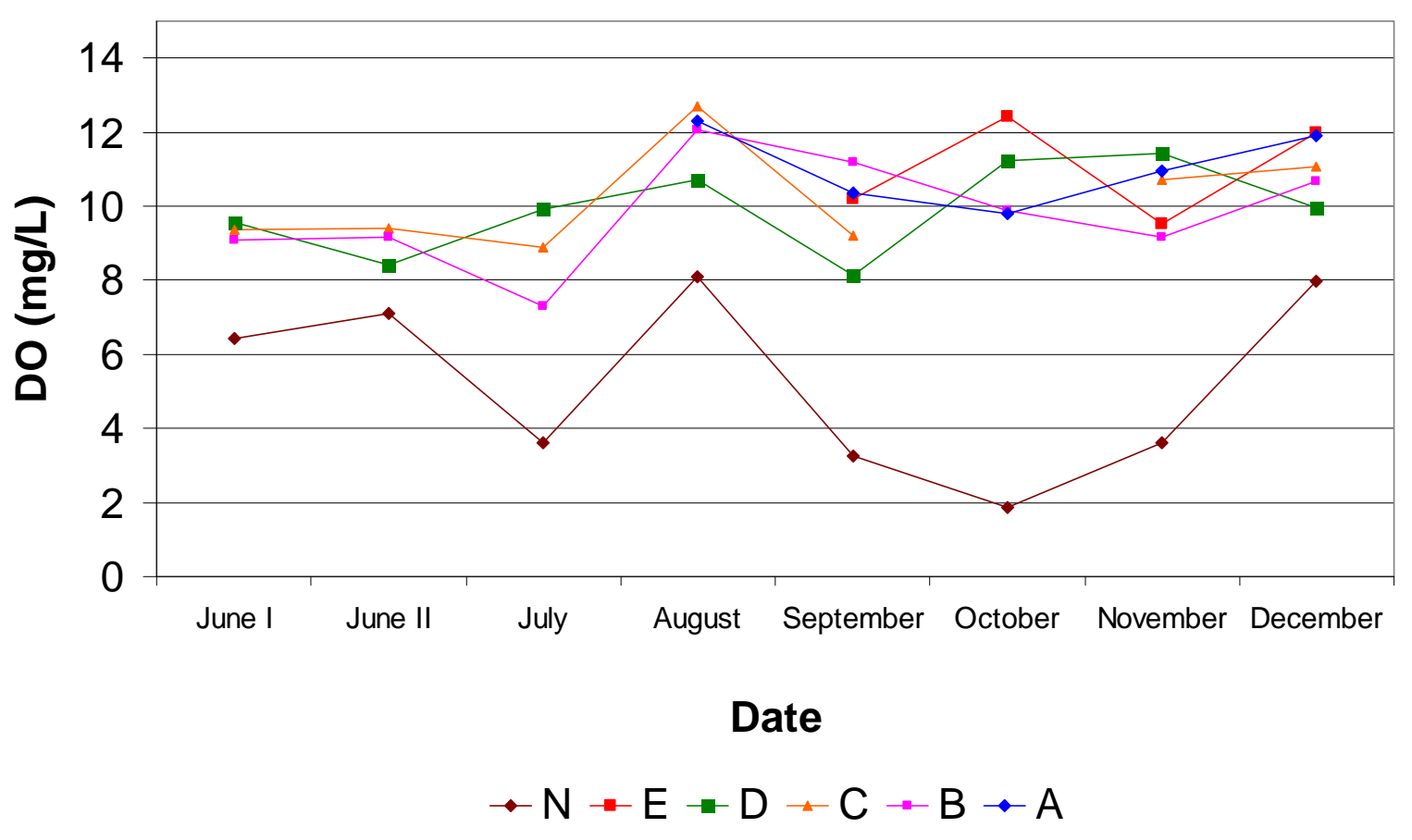

Figure 32. Dissolved Oxygen Data from Ancillary Measurements during Seining Events.

Current velocity measurements were negligible, if detectable at all. All measurements were $<0.02 \mathrm{~m} / \mathrm{s}$, with one exception. During the November sampling at Site A, velocity was $0.05 \mathrm{~m} / \mathrm{s}$; while this reading was the highest velocity we measured, it is still negligible (with reference to salmon, see Bottom et al. 2005, who suggest a velocity threshold of $0.30 \mathrm{~m} / \mathrm{s}$ for salmon; see also Appendix C, Table C1). We did not begin to measure water velocity until after the seasonal drop in river flow, so it is possible that we may see greater velocities at our sites during higher water levels in 2008.

GPS points collected at the time the beach seines were taken, show a shift in location of the seine hauls as the water level in the river fell in the late summer and rose in the fall. Beach slope transects were used to develop bathymetric contours for all sites (except Site E) so that seine location could be tied to site bathymetry (Figure 33, A-E, N). 

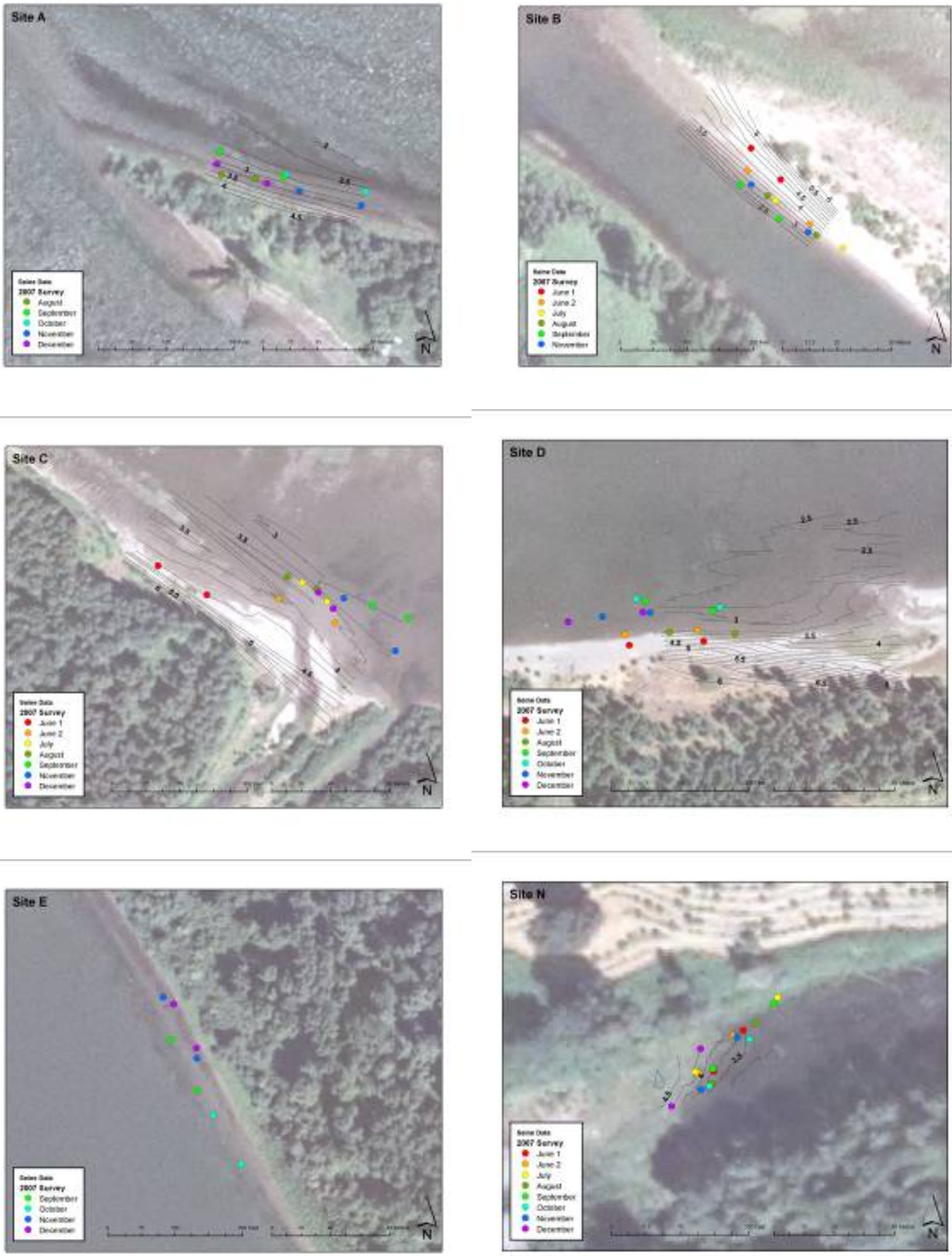

Figure 33. Seine Locations by Date for each Site

Photographs from photo points are included in Appendix D of this report. These also serve as a record of water level, and thus, beach seine locations throughout the course of the study. 


\subsubsection{Genetics}

Genotypic data were collected for 108 Chinook salmon and used in the genetic stock identification analysis. Results of the mixture analysis are presented in Table 10. Percentage estimates for four genetic stock groups (West Cascade Tributary Fall, Willamette River Spring, Deschutes River Fall, and Upper Columbia River Summer/Fall ${ }^{1}$ ) ranged from 11\% to 43\%, all with non-zero lower 95\% confidence intervals. Small contributions were also estimated for the West Cascade Tributary Spring (3\%) and Snake River Fall (6\%) stock groups. Results of individual fish probability assignments were summed by collection date (Figure 34) and site (Figure 35).

Assignment probabilities for the most likely stock group for each individual ranged from 0.51 to 1.00 with approximately $60 \%$ of the assignments greater than 0.90 (data not shown). Nearly all of the low probability assignments were fish with assignments split between the Deschutes River Fall and Upper Columbia River Summer/Fall groups (some of which potentially were released from Bonneville Pool hatcheries).

${ }^{1}$ It is important to note that many Upper Columbia River, Summer/Fall Chinook are released from Bonneville Pool hatcheries, and thus, may not truly emanate from the Upper Columbia River. 
Table 10. Genetic Stock Identifications . Estimated percentage genetic stock group composition and 95\% confidence intervals of 108 juvenile Chinook salmon sampled in the study area from June through December 2007.

\begin{tabular}{|c|c|c|}
\hline Genetic Stock Group and Baseline Populations & $\begin{array}{c}\text { Estimated } \\
\text { Contribution }\end{array}$ & $\begin{array}{l}\text { 95\% Confidence } \\
\text { Interval }\end{array}$ \\
\hline $\begin{array}{l}\text { West Cascade Tributary Fall } \\
\text { Cowlitz Hatchery } \\
\text { Lewis River } \\
\text { Sandy River } \\
\end{array}$ & $23 \%$ & $10 \%-28 \%$ \\
\hline $\begin{array}{l}\text { West Cascade Tributary Spring } \\
\text { Cowlitz Hatchery } \\
\text { Kalama Hatchery } \\
\text { Lewis Hatchery }\end{array}$ & $3 \%$ & $0 \%-10 \%$ \\
\hline $\begin{array}{l}\text { Willamette River Spring } \\
\text { Mckenzie Hatchery and River } \\
\text { North Santiam Hatchery and River } \\
\text { North Fork Clackamas River }\end{array}$ & $15 \%$ & $7 \%-21 \%$ \\
\hline \begin{tabular}{l}
\multicolumn{1}{c}{ Spring Creek Group Tule Fall } \\
Spring Creek Hatchery \\
Big Creek Hatchery \\
Elochoman River \\
Willamette River \\
\end{tabular} & $0 \%$ & $0 \%-5 \%$ \\
\hline $\begin{array}{l}\text { Deschutes River Fall } \\
\text { Lower Deschutes River } \\
\text { Upper Deschutes River }\end{array}$ & $11 \%$ & $1 \%-19 \%$ \\
\hline $\begin{array}{l}\quad \text { Upper Columbia River Summer/Fall* } \\
\text { Handford Reach } \\
\text { Methow River } \\
\text { Wells Hatchery } \\
\text { Wenatchee River }\end{array}$ & $43 \%$ & $33 \%-56 \%$ \\
\hline $\begin{array}{l}\quad \text { Mid and Upper Columbia River Spring } \\
\text { Carson Hatchery } \\
\text { John Day River } \\
\text { Upper Yakima River } \\
\text { Warm Springs Hatchery } \\
\text { Wenatchee Hatchery and River } \\
\end{array}$ & $0 \%$ & $0 \%-0 \%$ \\
\hline $\begin{array}{l}\text { Snake River Fall } \\
\text { Lyons Ferry Hatchery }\end{array}$ & $6 \%$ & $0 \%-15 \%$ \\
\hline $\begin{array}{l}\text { Snake River Spring } \\
\text { Imnaha River } \\
\text { Minam River } \\
\text { Rapid River Hatchery } \\
\text { Secech River } \\
\text { Tucannon Hatchery and River } \\
\text { Newsome Creek } \\
\text { West Fork Yankee Creek }\end{array}$ & $0 \%$ & $0 \%-2 \%$ \\
\hline
\end{tabular}

*Fish from this stock are released at Bonneville Hatchery, Little White Hatchery, and other Bonneville Pool hatcheries, as well as possibly from lower river hatcheries. 


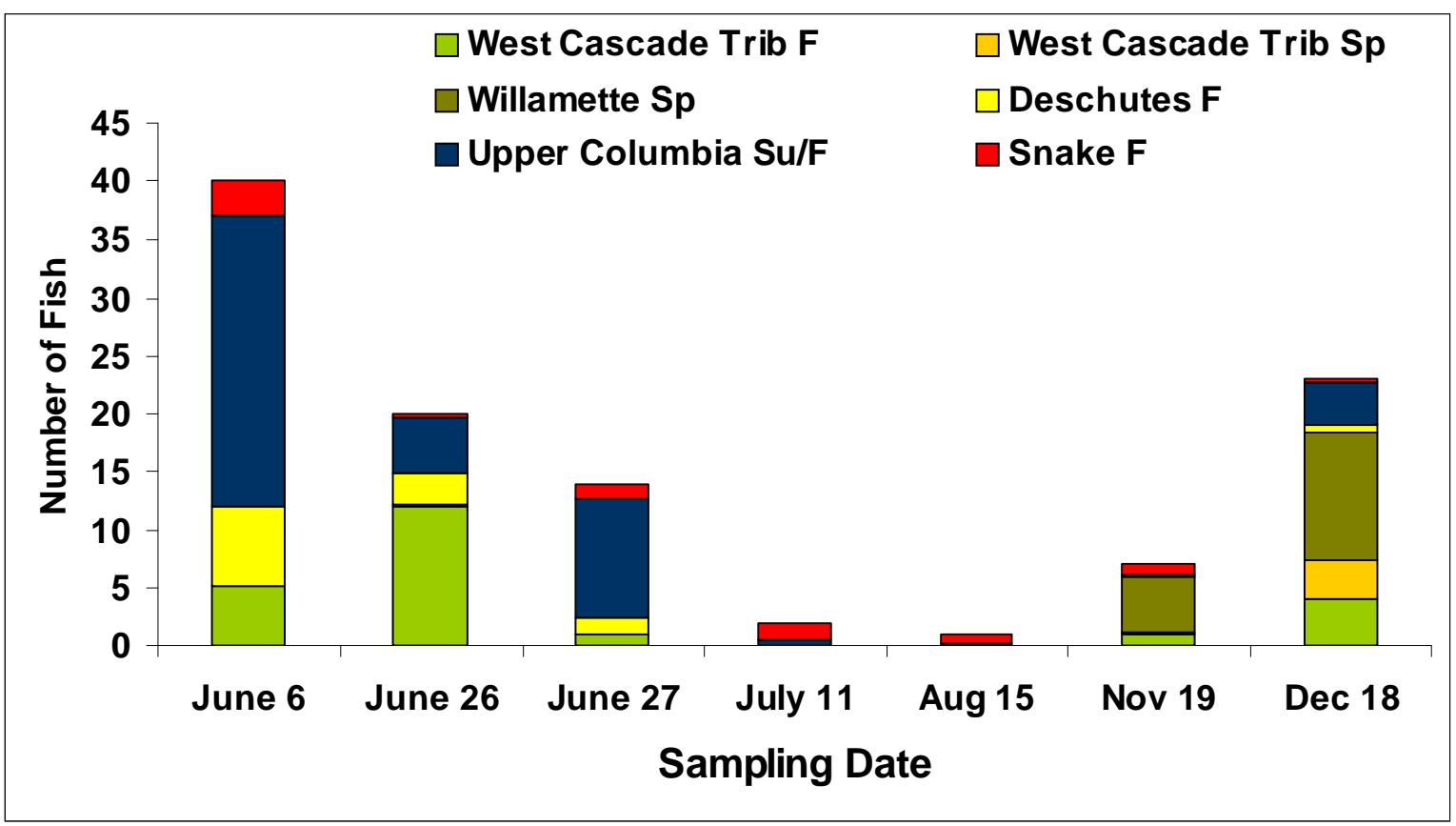

Figure 34. Sums of Fractional Genetic Assignments of Individual Chinook Salmon by Collection

Date. Fractions for the Spring Creek Group Tule Falls, Mid and Upper Columbia Springs, and Snake Springs totaled to 0.25 and are not shown. $\mathrm{F}=$ fall run, $\mathrm{Su}=$ summer run, $\mathrm{Sp}=$ spring run.

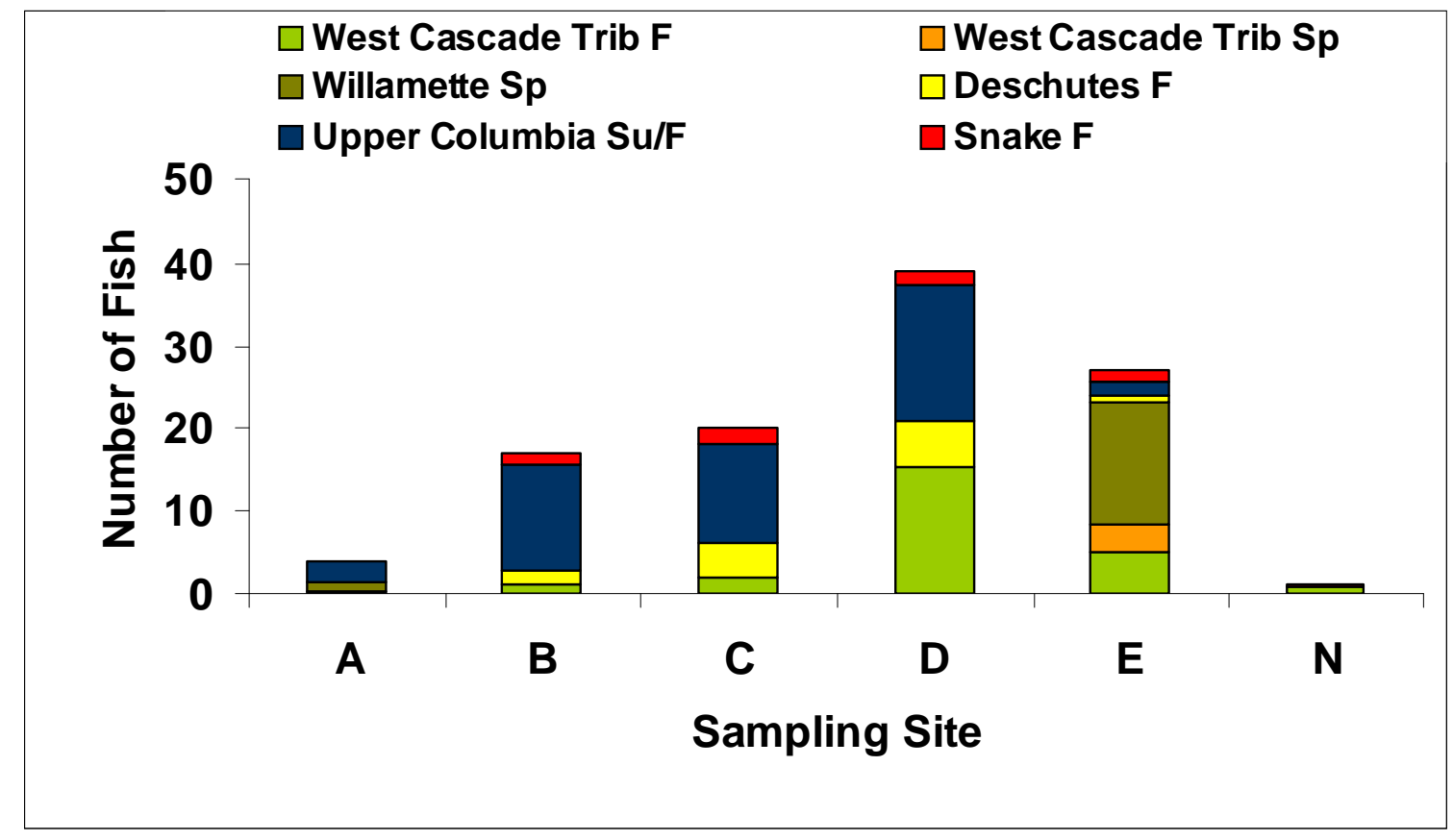

Figure 35. Sums of Fractional Genetic Assignments of Individual Chinook Salmon by Sampling Site. Fractions for the Spring Creek Group Tule Falls, Mid and Upper Columbia Springs, and Snake Springs totaled to 0.25 and are not shown. $\mathrm{F}=$ fall run, $\mathrm{Su}=$ summer run, $\mathrm{Sp}=$ spring run. 


\subsection{Fish Catch Variance Analysis}

This report summarizes the variance component analyses described in the 2007 statistical study plan. Components of variance associated with between-site variability and within-site variability are characterized and summarized. Also evaluated is the temporal correlations in fish and non-fish densities between sites over time.

\subsubsection{Variance-to-Mean Relationships}

The roughly monthly monitoring data on fish density was analyzed using a one-way ANOVA where replicate beach seines were classified by location. The mean squares from the one-way ANOVA were equated to their expected values to estimate variance components associated with measurement error and spatial variance $\left(\sigma_{s}^{2}\right)$. These monthly estimates of spatial variability $\left(\hat{\sigma}_{s}^{2}\right)$ were then regressed against monthly mean densities $(\mu)$ to investigate variance-to-mean relationships (Fig. 36). Separate analyses were conducted for salmon (Chinook and coho pooled), pooled nonsalmonid fishes, pooled non-fish species, and five separate fish species (Fig. 36). In all cases, the negative binomial and log-normal variance-to-mean relationships applied equally well. Coefficients for the negative binomial rule,

$$
\sigma_{S}^{2}=\mu+\frac{\mu^{2}}{c_{1}},
$$

were approximately the inverse of the coefficients for the log-normal variance rule (Table 11),

$$
\sigma_{S}^{2}=c_{2} \mu^{2}
$$

The variance-to-mean curves fit the data better for salmon and non-fish taxa than pooled nonsalmon which represented 31 different fish species. Better variance-to-mean relationships for nonsalmonid fishes were found when separate analyses were performed for five individual fish species (Fig. 36), as might be expected.

The smaller the negative binomial coefficient (or larger the log-normal coefficient), the more rapidly the spatial variance increases with increasing fish density. For example, banded killifish had the largest negative binomial coefficient while threespine stickleback had the smallest. The implication is that if a restoration activity is going to enhance fish numbers, it will be easier to detect change for those species with shallower variance-to-mean relationships (i.e., large negative binomial coefficients). In other words, for the same level of statistical performance, few monitoring sites will be needed for those species with larger negative binomial coefficients. 
a. Mean monthly density of pooled Chinook and coho salmon versus spatial variance.

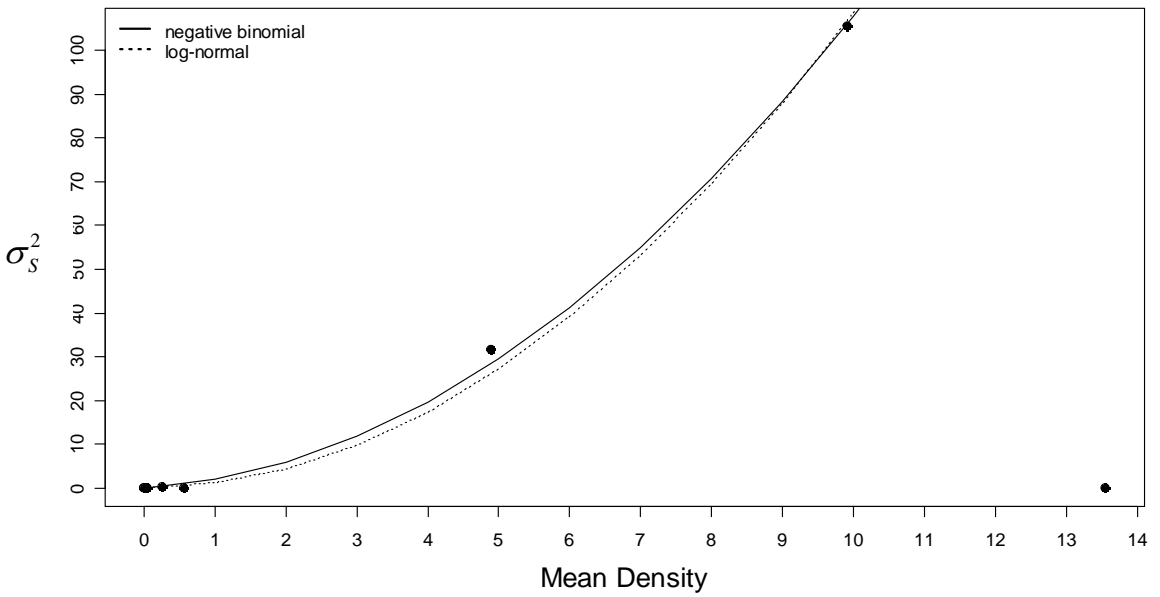

b. Mean monthly density of pooled non-salmonid fish species versus spatial variance.

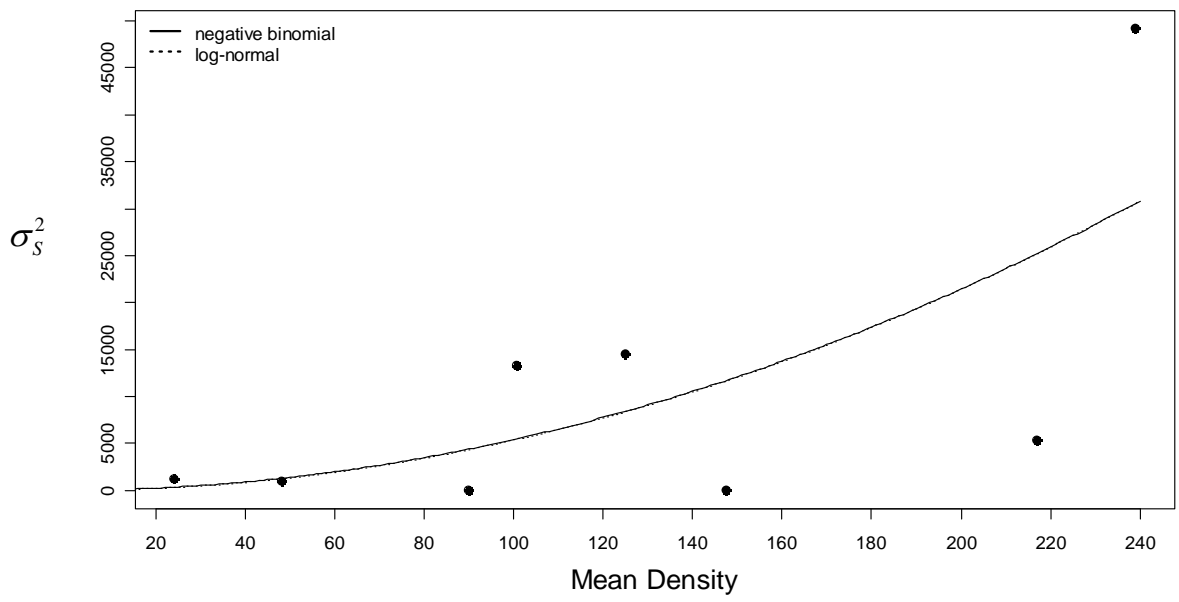

Figure 36. Spatial variance-to-mean density relationships using monthly beach seine data for various taxonomic groups; (a) all salmon, (b) all non-salmonid fish (c) non-fish, (d) bluegill, (e) banded killifish, (f) northern pikeminnow, (g) peamouth, and (h) threespine stickleback. 
c. Mean monthly density of pooled non-fish species versus spatial variance.

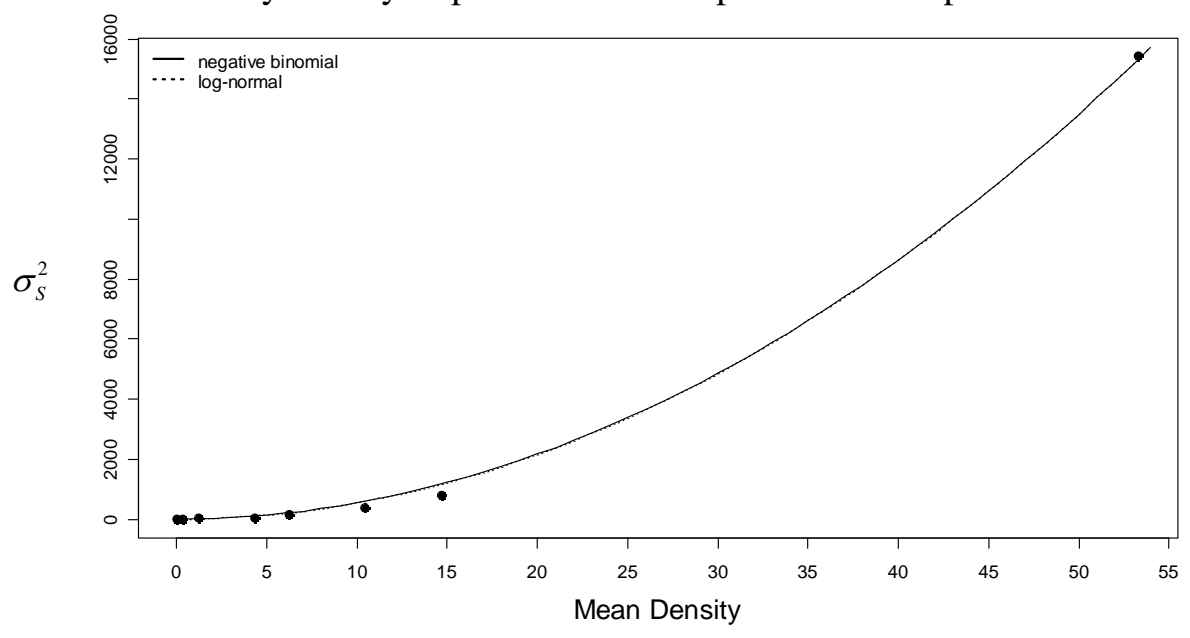

d. Mean monthly density of bluegill versus spatial variance.

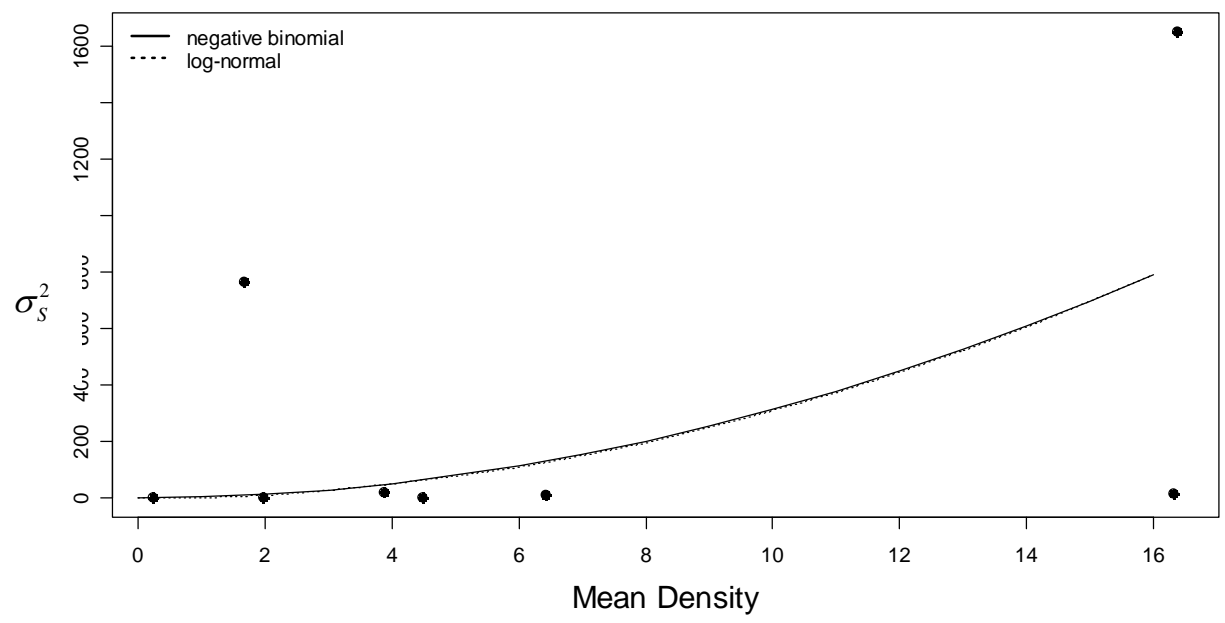

Figure 36 (cont.). Spatial variance-to-mean density relationships using monthly beach seine data for various taxonomic groups; (a) all salmon, (b) all non-salmonid fish (c) non-fish, (d) bluegill, (e) banded killifish, (f) northern pikeminnow, (g) peamouth, and (h) threespine stickleback. 
e. Mean monthly density of banded killifish versus spatial variance.

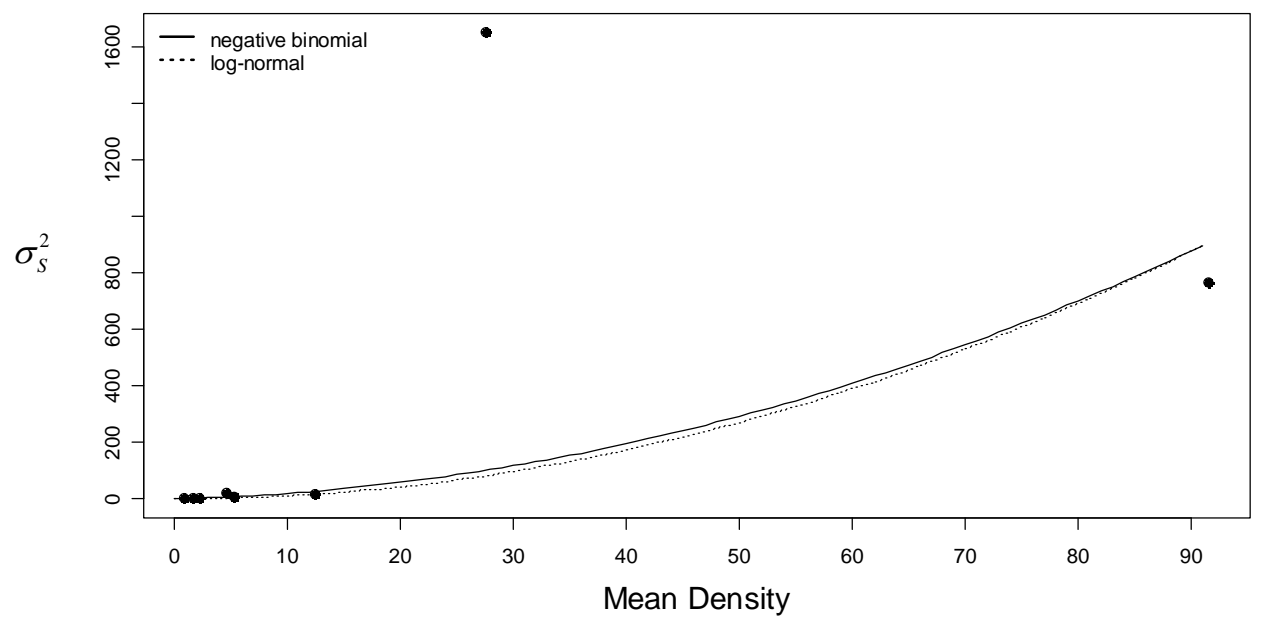

f. Mean monthly density of northern pikeminnow versus spatial variance.

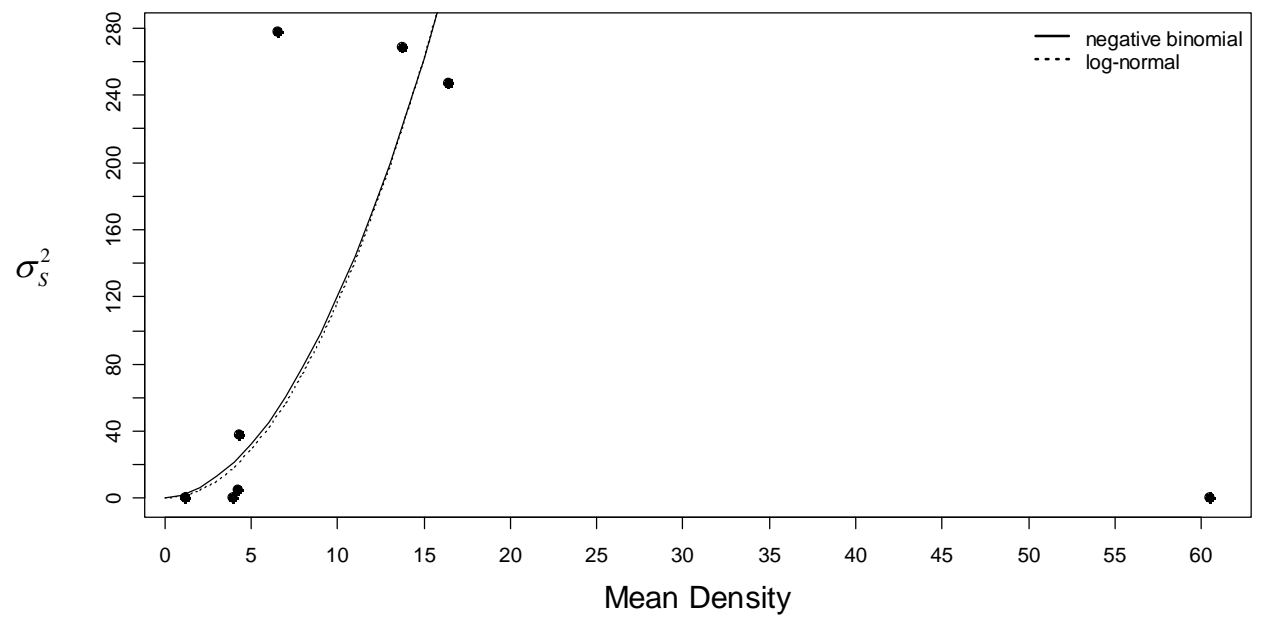

Figure 36 (cont.). Spatial variance-to-mean density relationships using monthly beach seine data for various taxonomic groups; (a) all salmon, (b) all non-salmonid fish (c) non-fish, (d) bluegill, (e) banded killifish, (f) northern pikeminnow, (g) peamouth, and (h) threespine stickleback. 
g. Mean monthly density of peamouth versus spatial variance.

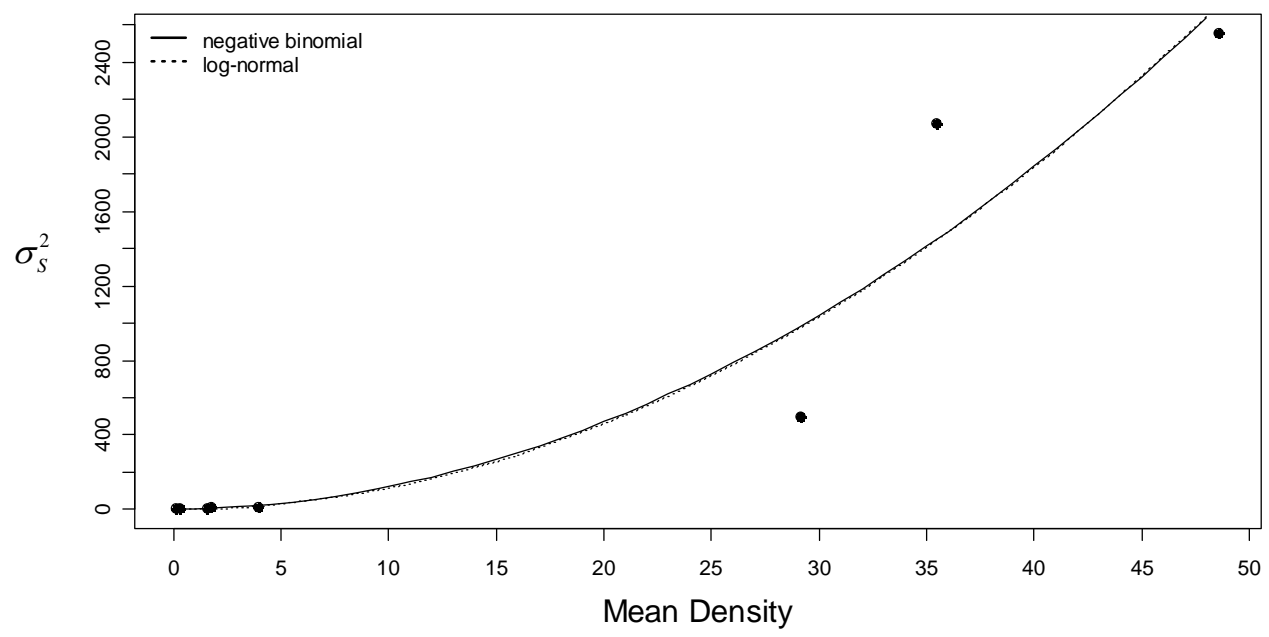

h. Mean monthly density of threespine stickleback versus spatial variance.

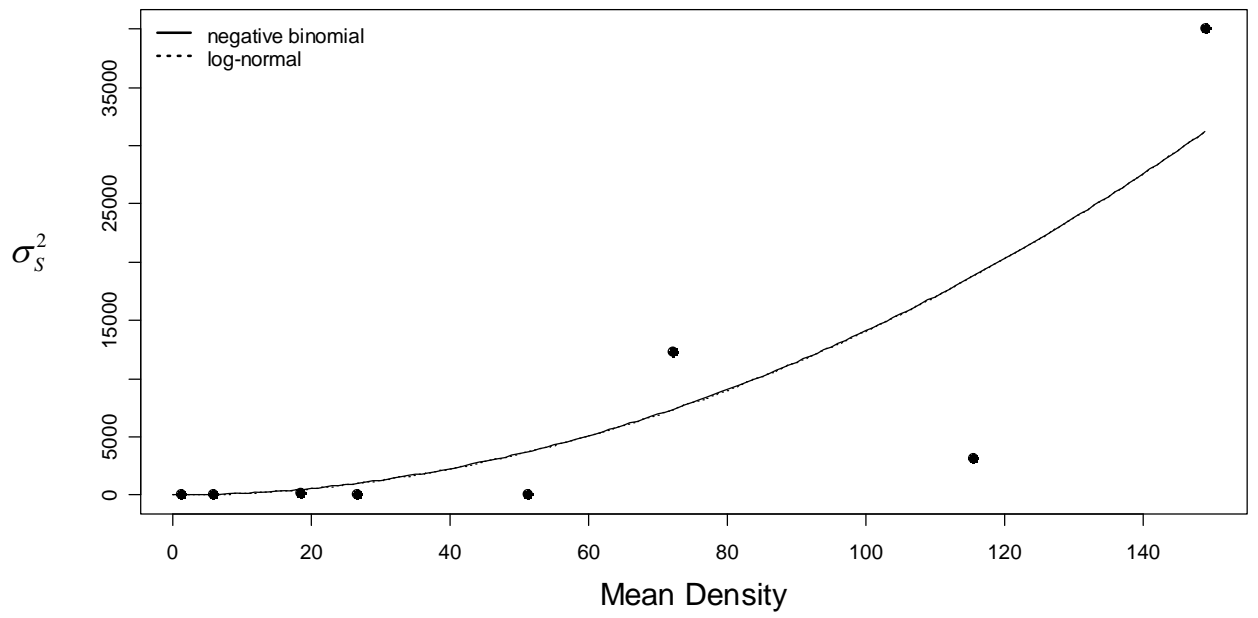

Figure 36 (cont.). Spatial variance-to-mean density relationships using monthly beach seine data for various taxonomic groups; (a) all salmon, (b) all non-salmonid fish (c) non-fish, (d) bluegill, (e) banded killifish, (f) northern pikeminnow, (g) peamouth, and (h) threespine stickleback. 
Table 11. Negative binomial [Eq. (4)] and log-normal [Eq. (5)] coefficients associated with spatial variance-to-mean relationships and coefficients of variation (CV) for replicate beach seines.

\begin{tabular}{lccc}
\hline \multicolumn{1}{c}{ Taxa } & Negative binomial $\left(c_{1}\right)$ & Log-normal $\left(c_{2}\right)$ & $\overline{\mathrm{CV}(D)}$ \\
\hline Pooled salmonids & 1.0209 & 1.0862 & 1.5535 \\
All non-salmonid fish & 1.8835 & 0.5358 & 1.2648 \\
Non-fish & 0.1860 & 5.3967 & 1.9440 \\
Bluegill & 0.3299 & 3.0944 & 1.3696 \\
Banded Killifish & 10.3050 & 0.1082 & 1.7313 \\
Northern Pikeminnow & 0.9097 & 1.1669 & 1.6289 \\
Peamouth & 0.8886 & 1.1488 & 1.3707 \\
Threespine Stickleback & 0.1860 & 5.3967 & 1.4523 \\
\hline
\end{tabular}

The variance-to-mean relationships estimated here will be useful in helping determine the amount of spatial replication needed in future regional monitoring plans.

\subsubsection{Within-Site Sampling Error}

At each site during each survey period, two replicate beach seines were sampled. This replication allowed the component of variance associated with sampling error to be extracted from the survey data. This within-site, within-period variability will influence how much within-site sampling effort is needed to characterize fish densities on an occasion. Defining precision in terms of relative error, i.e.,

$$
P\left(\left|\frac{\hat{\bar{D}}-\bar{D}}{\bar{D}}\right|<\varepsilon\right)=1-\alpha .
$$

The error in estimation of mean density $(\bar{D})$ can be expressed as

$$
\varepsilon=Z_{1-\frac{\alpha}{2}} \mathrm{CV}(\hat{\bar{D}})
$$

or

$$
\varepsilon=Z_{1-\frac{\alpha}{2}} \frac{\mathrm{CV}(D)}{\sqrt{n}},
$$

where $n=$ number of replicate beach seines taken, 


$$
\mathrm{CV}(D)=\frac{S_{D}}{\bar{D}}
$$

and $S_{D}=$ standard deviation in density between replicate beach seines.

Hence, the average CV for the replicate beach seines provides necessary information for determining within-site sampling effort (Table 9).

Of the eight taxonomic groups examined (Table 9), pooled non-salmonids had the smallest average CV of 1.26 while pooled non-fish had the largest average CV of 1.94. Surprisingly, the range in CVs was quite narrow, 1.26-1.94, but the magnitude was quite large. The standard deviations $\left(s_{D}\right)$ were between 1 and 2 times larger than the mean densities $(\bar{D})$. The result is that numerous beach seine samples would be necessary to estimate mean density precisely at a site (Fig. 37). For example, to estimate mean density within $\pm 50 \%$ of the true value $95 \%$ of the time, sample sizes between $n=30$ and 80 would need to be used (Fig. 37). The number of replicate beach seines would be more than could be collected from a site without disturbing the habitat being studied.

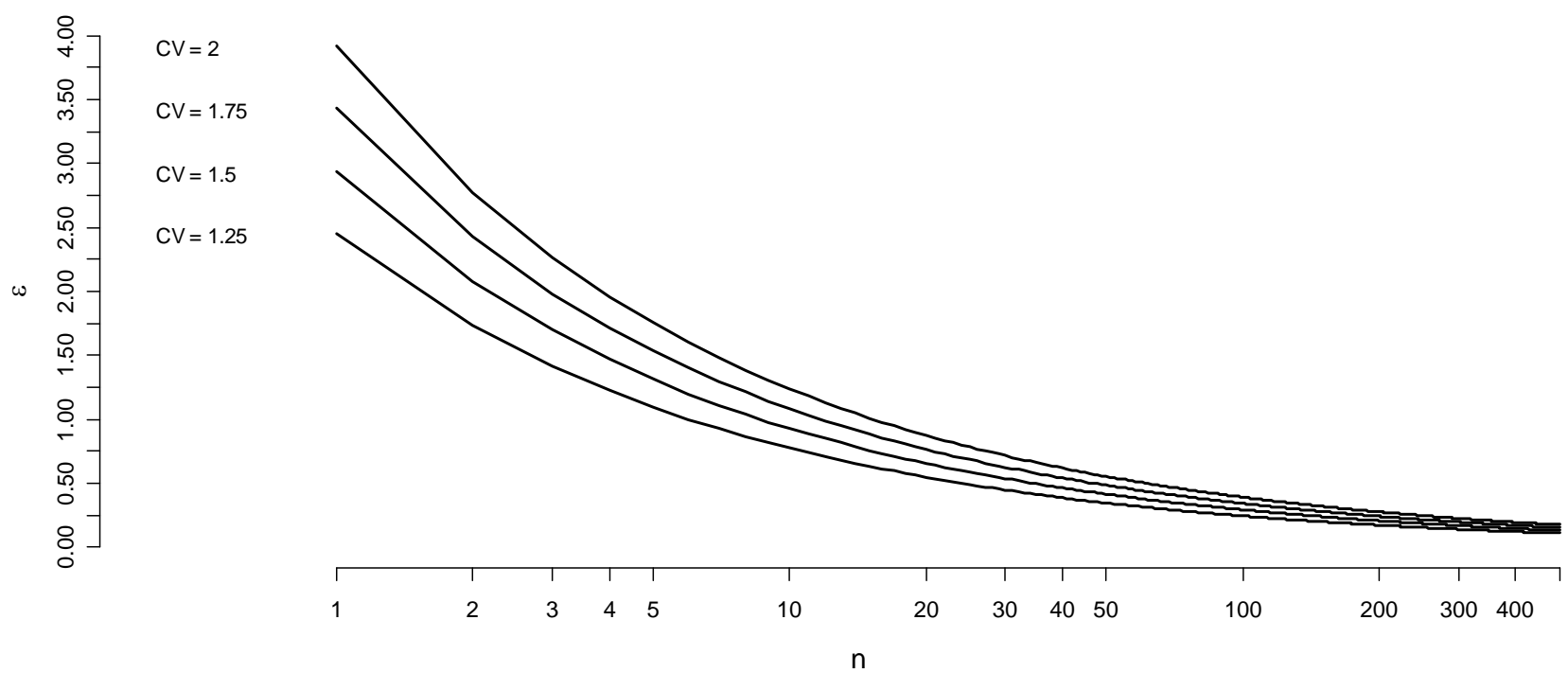

Figure 37. Sample size curves for estimating mean density at a site as a fraction of the coefficient of variation (CV) in densities encountered (1.25-2.0). Precision expressed in terms of relative $\varepsilon$, $95 \%$ of the time. 


\subsubsection{Spatial Correlation between Sites}

For many of the monitoring designs based on the principles of paired sites (i.e., before-aftercontrol-impact [BACI], restoration-reference, control-treatment), the statistical power will depend not only on spatial variability (Section 4.3.1) and within-site measurement error (Section 4.3.2) but also how well the sites tracked one another (i.e., correlated) over time. The intra-class correlation coefficient was used to calculate correlations between all sites (i.e., B, C, E, N) and sites within a habitat type ( $\mathrm{C}$ and $\mathrm{B}$, open channel; $\mathrm{N}$ and $\mathrm{B}$, off-channel sites) (Table 10). In interpreting the results, it must be kept in mind the very small number of replicate sites (i.e., four or two) used in the analyses.

In general, if there was a correlation between sites, it would be expected to be positive. The various sites responding to similar environmental changes over time might be expected to produce similar trends in fish response over time. The variance component analyses often estimated a negative intra-class correlation (Table 12) which should be interpreted, therefore, as $\rho_{I}=0$. Consequently, in seven out of eight various taxonomic groups, the correlations should be interpreted as small or nonexistent. The single exception appears to be bluegill, a warm-water species that showed strong positive correlations across all sites (B, C, E, N), as well as the off-channel sites $\mathrm{N}$ and B.

The conclusion from the results is that any benefit from paired designs due to the assumption of a position correlation between reference and treatment sites in terms of fish density response will be minimal at best. Randomized two-treatment designs may work nearly as well as, or equal to, paireddesign approaches to restoration monitoring.

Table 12. Estimates of intra-class correlation for sites over time for various taxonomic groups. For sites B and N, all months of data were used. For sites C and B and all sites (B, C, E, N), only the months of September, November, and December 2007 were used in the analysis.

\begin{tabular}{lccc}
\hline \multicolumn{1}{c}{ Taxa } & Sites B, C, E, N & Sites C and E & Sites N and B \\
\hline Pooled salmon & 0.1440 & 0.1837 & -0.2078 \\
All non-salmonid fish & -4.05 & -0.7073 & 0.2621 \\
Non-fish & -0.3391 & 0.0 & -0.2256 \\
Bluegill & 0.4339 & -1.3177 & 0.7665 \\
Banded Killifish & -0.1773 & -0.1068 & -0.0644 \\
Northern Pikeminnow & 0.4222 & -0.2299 & -0.5341 \\
Peamouth & 0.5337 & -0.1114 & -0.2113 \\
Threespine Stickleback & -0.9692 & -0.4944 & -0.3175 \\
\hline
\end{tabular}




\subsection{Acoustic Telemetry}

Species Composition, Sources and Distribution of JSATS-Tagged Fish. A total of 577 yearling and subyearling Chinook salmon implanted with JSATS transmitters and released at Bonneville and Lower Granite dams had valid detections at the acoustic nodes in the study area (Table 13). The majority of these detections (545 of 577) were part of the Bonneville Spillway and Post-FCRPS Survival Studies. The remaining 32 fish from Lower Granite detected in our study were likely part of the Tag Effects Study. Most fish were detected at the Reed Island node, followed by the Gary Island node. Eight fish were present near the node at the old Sandy delta (mouth of the old river channel). At Chatham Island, JSATS-tagged fish were detected but none met the criterion for a valid detection event (i.e., four quality JSATS-tag transmissions within a 60 sec window).

Table 13. Numbers of Valid Detections of JSATS-Tagged Chinook Salmon at the Nodes by Life History Type and Release Location (BON=Bonneville Dam and LGR=Lower Granite Dam).

\begin{tabular}{ccccccc}
\hline Node & LGR & BON & LGR & BON & Total & Proportion \\
\hline Reed Is. & 15 & 294 & 10 & 161 & 480 & 0.832 \\
Gary Is. & 4 & 76 & 2 & 7 & 89 & 0.154 \\
Old Sandy Delta $^{*}$ & 1 & 6 & 0 & 1 & 8 & 0.014 \\
Chatham Is. $^{* *}$ & 0 & 0 & 0 & 0 & 0 & 0.00 \\
\hline Total & 20 & 376 & 12 & 169 & 577 & \\
\hline
\end{tabular}

* Five yearlings detected on both Gary and Old Sandy were counted as just Old Sandy. ** The reason for the lack of valid detection events at Chatham Is. has yet to be determined.

Run Timing of JSATS-Tagged Fish. Run timing is represented by the total number of valid detections of tagged fish per day for all four nodes combined (Figure 38). There were distinct peaks in run timing, with the largest occurring in May 2007. These peaks reflect the pulses of tagged fish released from Bonneville Dam. The decline in the amplitude of the peaks may be related to diminished water volume or increased temperature entering these increasingly shallow sites as the summer progressed. 


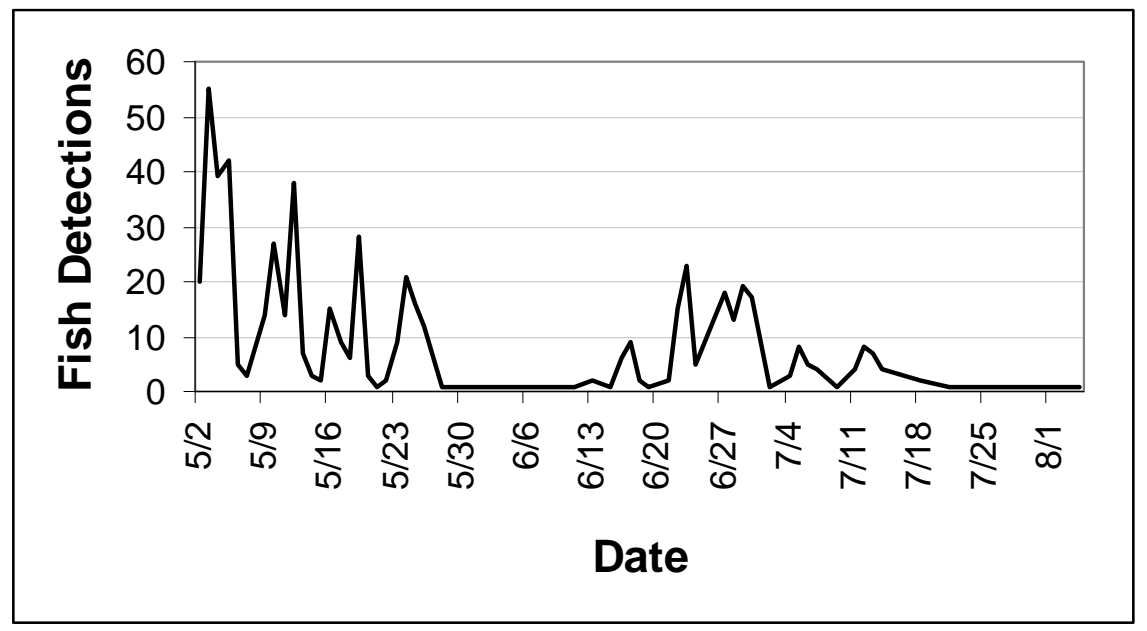

Figure 38. Run Timing Based on Total Valid Detections of Unique JSATS-Tagged Fish for All Locations Combined (Reed Island, Gary Island, Old Sandy Channel).

Residence Time. Residence time, as estimated by the mean duration between first and last valid detections, was longer for subyearlings than yearlings for a given release location. In fact, residence time was 10 times and 5 times longer for subyearlings than for yearlings released at Lower Granite and Bonneville dams, respectively (Table 14). Lower Granite and Bonneville Dams are 510 rkm and $38 \mathrm{rkm}$, respectively, from the study area. The longest mean residence time (335 h) was for a subyearling released at Bonneville.

Table 14. Residence Time (h) as Determined by Mean Duration between First and Last Valid Detections at a Given Sample Site.

\begin{tabular}{ccccc}
\hline & \multicolumn{2}{c}{ Yearlings } & \multicolumn{2}{c}{ Subyearlings } \\
\hline Statistic* & LGR & BON & LGR & BON \\
\hline $\mathrm{n}$ & 17 & 349 & 9 & 144 \\
Minimum & 0.00 & 0.00 & 0.01 & 0.00 \\
Maximum & 0.20 & 108.95 & 3.57 & 335.33 \\
Mean & 0.05 & 0.81 & 0.50 & 3.98 \\
Standard Deviation & 0.05 & 6.12 & 1.16 & 29.92 \\
\hline
\end{tabular}

Migration Pathways. The detection histories indicate that the majority of the JSATS-tagged fish — $89 \%$ of the yearlings and $96 \%$ of the subyearlings — used the main river channel (Table 15; see the first footnote for the population the percentages pertain to). A portion of the tagged fish (9\% yearlings and 3\% subyearlings) apparently used the route between Reed Island and the Washington shore. A fraction of the yearlings and subyearlings, $3 \%$ and $0.3 \%$, respectively, used the route along the Oregon shore at the Sandy delta and Gary Island. No fish were observed to have crossed over between the Reed Island and Sandy delta pathways. 
Table 15. Migration Pathways for Yearling and Subyearling Chinook Salmon Tagged with JSATS Transmitters and Having Valid Detections at Nodes in the Study Area. Pathways are defined below the table.

\begin{tabular}{ccccc}
\hline & \multicolumn{2}{c}{ Yearlings } & \multicolumn{2}{c}{ Subyearlings } \\
\hline Pathways* & Freq. & Percentage & Freq. & Percentage \\
\hline Main Channel** & 3210 & $89.1 \%$ & 4832 & $96.3 \%$ \\
Behind Reed Is.*** & 309 & $8.6 \%$ & 170 & $3.4 \%$ \\
Sandy Delta**** & 82 & $2.3 \%$ & 14 & $0.3 \%$ \\
\hline
\end{tabular}

* Includes all fish detected at Reed, Gary Is., and Old Sandy Delta and those detected on both the secondary and tertiary arrays for the Bonneville Spillway Survival Study that were place upstream and downstream of our study area, respectively.

** Main Channel = fish detected on both the secondary and tertiary Survival Study arrays, but not any of the four TFM nodes.

*** Behind Reed Island = fish detected on the Reed Island node, but not the Gary Island or Old Sandy Delta nodes.

**** Sandy Delta $=$ fish detected on the Gary Island or Old Sandy Delta nodes, but not the Reed Island node. 


\subsection{Discussion}

Discussion topics include methods considerations, habitat characteristics, fish community characteristics, acoustic telemetry, and the role of this study for baseline data for the proposed rechannelization.

\subsection{Methods Considerations}

\subsubsection{Suitability of Methods}

The sampling methods we used in 2007 were sufficient for coarsely assessing fish use of shallow water areas and testing the feasibility of acoustic telemetry in these areas. Note that by the time work was authorized and collection permits were obtained, the peak outmigration of salmon in 2007 had passed. However, springtime data will be collected in 2008 with sampling scheduled to continue without interruption. Additionally, monthly sampling may be too coarse to capture the full range of salmon occurrence and abundance at our sampling sites. The recurrence of salmonids at Site $\mathrm{E}$ in December, in large numbers, leads to question whether similar fish were there a few weeks before in moderate numbers or if a pulse of Chinook salmon simply passed through. While most salmon studies in the Pacific Northwest have increased sampling effort during the spring and summer periods, it may be more informative to sample with increased frequency at the beginning and end of the outmigration period as well as "off-season" to capture fish that may be using the LCRE in atypical patterns.

Sampling in large riverine systems is difficult due to high river velocity, low in-water visibility, and obstacles that may entangle a net. Conditions in the LCRE are complicated further by wide seasonal variations in river flow/water level and daily variation in water level cause by FCRPS operations and tides. Access to off-channel sites, specifically Sites B, C and E, was often problematic at low water, when the draft of the boat exceeded water levels. While a smaller boat may prove more successful at accessing shallow water sites, carrying the crew and gear needed for the seining operation could be limiting.

The net employed in this study, as described above, was logistically suitable for sampling, given that it could be set by foot or boat. It's relatively small size, at just $30.5 \mathrm{~m}$, however, may make it less efficient than a larger net. On the other hand, during periods of high river flow with increased velocity, a larger net could prove cumbersome. The field crew will conducted a gear comparison using the current net and several others in February 2008 to assess the feasibility and success of multiple gear-types; a synopsis of that effort is presented as Appendix E of this report. The recommendations of the field team are to modify the net by adding bridles and haul lines, to achieve more consistent sets over a greater area. 


\subsubsection{Sampling Design}

The six beach seine sampling locations were selected to represent an array of shallow freshwater tidal habitats within reach $\mathrm{G}$ of the hydro-geomorphological classification system of the Lower Columbia River. The monthly sampling scheme provides a snapshot at the fish assemblage within each of the sites; however, this frequency of sampling probably falls short of accurately depicting the population structure of fish within these habitats. Increasing the periodicity of sampling would help to fill in the gaps with regard to the population structure of migratory fish such as salmon. However, the analysis of variance showed that the level of diversity in catch with each haul would require an extremely large number of samples $(>n=30)$ to accurately depict fish populations at the sites on each date. Given that this level of sampling is unrealistic and would likely alter the very habitats we're trying to sample, our efforts to characterize fish that occur at these sites and the seasonal patterns of their occurrence through monthly sampling appear to be adequate for a coarse overview.

\subsubsection{Site Representativeness}

While six sites cannot capture the full range of conditions in the tidal freshwater region of the LCRE, we have captured several site types with replicates of two general types: steeply sloping, deepwater beaches ( $\mathrm{B}$ and $\mathrm{E}$ ) and sandy shallows ( $\mathrm{C}$ and $\mathrm{D})$. Additionally, we have sites on floodplains $(\mathrm{C}, \mathrm{D}, \mathrm{N})$, islands (A, B, E) and also near and away from a major river confluence (D and A, respectively). This reach of the river lacks the sloughs formed by more extreme tidal action downstream and possesses riparian habitat more characteristic of river systems. Rather than large swaths of emergent wetland, seasonal emergent wetlands tend to border islands and the banks of the river. From a hydrological standpoint, all of our sites are off the mainstem of the river; the inclusion of additional sites in subsequent years should take this into account.

Perhaps more important from a fish perspective is the presence of structure at the sites. In all cases, woody debris was absent in the area of our sampling. However, at several sites (B, E, N) the presence of dense submerged aquatic vegetation (SAV) may influence fish community composition and abundance by providing increased habitat complexity. While it has been well documented that fish are attracted to structure, the presence of SAV may also confound sampling because it interferes with the net (the lead line often rides over the SAV) as it is hauled in; thus, patterns in fish distribution related to the presence of SAV may not be evident from our sampling (nor were they directly measured).

\subsection{Habitat Characteristics}

\subsubsection{Site Similarities}

Sites in this study represent a number of habitat types. Beach slope and maximum depth varied between sites, with Sites B and E proving similar, having steeper slope and a drop-off to deeper water, and Sites $\mathrm{C}$ and $\mathrm{D}$ having shallow slope and being characterized by an area of shallow flats 
with coarse sand and gravel. Sites A and N added to additional site types to the suite of sites; Site A was a fringing marsh site, and Site $\mathrm{N}$ was most unique, as a seasonally connected wetland.

\subsubsection{Bathymetry}

The inclusion of beach slope transects in this study allowed us to look at bathymetry at each site. This was especially important because of the need to locate the seine hauls in different locations each sampling period (see Figure 33) due to the rise and fall of the river level and the movement of the water's edge across the beach face. Bathymetry may be particularly important for juvenile salmonids, as it has been well documented that subyearlings generally inhabit the shallow fringe, while yearlings prefer deeper water (Dawley et al. 1986). The relative bathymetry at a site at any given water level may determine the distribution of salmonids; it is likely that other fish species assemble in a similar way, with larger fish preferring deeper water.

Currently, high quality bathymetric data is lacking for areas adjacent to the main navigation channel in the Columbia River. These fringing habitats may be among the more important areas for some juvenile salmonid life history types, providing rearing opportunity and refuge from strong downstream flow. While fish presence does not prove habitat utilization, shallow areas are thought to be highly productive areas for aquatic insects, a prey item for salmonids; future work will include diet analysis to determine what fish are feeding on in this reach. Understanding shallow water bathymetry and the amount of shallow water area that may be potential rearing habitat would assist in designing a study directly addressing the preference of one habitat type over another (e.g. shallow vs. deep main channel) for a given species and size class.

\subsection{Fish Community Characteristics}

\subsubsection{Assemblage}

Our monthly beach seine effort encountered 23 species and seven genera during the 2007 season. While the effort likely provides an accurate representation of the fish assemblage at the site level, the sampling frequency may not be robust enough to accurately represent the migratory nature of juvenile salmonids in the shallow freshwater tidal habitats in our study. The five most abundant species comprising the overall catch composition include three native and two nonnative fishes. All five of these species (threespine stickleback, banded killifish, peamouth, northern pikeminnow, and bluegill) are commonly encountered at other sites within the lower Columbia River (Pearson et al. 2006).

Most of our sampling period occurred during the summer months when water temperatures were seasonally elevated. It is hypothesized that juvenile salmon presence is regulated by water temperatures greater than $20^{\circ} \mathrm{C}$ (Bottom et al. 2005), when fish metabolic activity becomes stressed. We did not capture large numbers of salmon at our sites until November; this could be due in part to temperature, but also due to migration patterns associated with different stocks or life-history types. 
Temporal trends in growth are difficult to identify at the site level due to the absence of salmon throughout much of the summer and early fall months. For example, Chinook salmon were found at Site C only during June and December. While the mean fork length of Chinook salmon measured in December was larger than that of the mean from June, variation within the data does not provide conclusive evidence for a significant difference in size between the two dates. A large range in Chinook salmon size was observed at Sites A and E in December, however data from earlier months is lacking, therefore comparisons in temporal trends are not possible. Additionally, different stocks (having different size structures) were probably migrating through the sampling area throughout the year.

\subsubsection{Salmon, Hatchery versus Wild}

Only three salmon known to be of hatchery origin (adipose fin clipped) were captured during the sampling period. Telemetry data, including residence time and migration pathways derived from these data, indicate yearling and subyearling Chinook salmon released at Bonneville and Lower Granite dams likely used a limited portion (i.e., the main channel of the Columbia River) of the tidal freshwater area as a migration corridor, with only a small proportion of tagged fish using side channels. The rapid and directed migration of acoustic-tagged fish (which are mostly of hatchery origin) may identify a general trend, helping to explain the few hatchery salmon we collected. Those salmon we did encounter at our sites (both wild and marked) may be unable to complete migration due to energetic deficiencies (i.e., salmon may have used our sites to restore energy reserves) and may seek out low-velocity off-channel pathways for foraging and refuge.

Research in the Pacific Northwest suggests juvenile Chinook salmon can spend as much as six to nine months in certain estuarine areas feeding and growing (Myers and Horton 1982, Simenstad et al. 1982, Healey 1991; cited in MacFarlane and Norton 2002), and presumably replenishing energy stores. High lipid content is common in hatchery-reared fish, which are often provided high rations of energy rich feed (Shearer et al. 1997). Hatchery salmonids may be better prepared energetically than wild fish to complete migration without replenishing energy stores. This contrast in energetic requirement, and associated differences in residence time, may account for some of the difference between numbers of hatchery and unmarked salmonids collected in our seine hauls. Conversely, it is

possible that wild fish are more likely to use the mosaic of habitats available in the river for rearing as they migrate.

It should be noted that in our study unmarked fish were assumed to be of wild origin. However, not all hatchery fish released into the Columbia River are marked (E. Tinus, Oregon Department of Fish and Wildlife, personal communication). Therefore, some number of unmarked salmonids in our catches may actually have been of hatchery origin; at this time conclusions based on the relative numbers of hatchery versus unmarked fish are not possible. 


\subsubsection{Predators}

Of the 30 fish taxa encountered in our sampling, eight species-bluegill, largemouth bass, smallmouth bass, brown bullhead, crappie, northern pikeminnow, white sturgeon, and yellow perchare known to be opportunistically piscivorous as adults. Among these species, only northern pikeminnow accounted for an appreciable portion (10\%) of the total combined catch. Small pikeminnow (102 - $257 \mathrm{~mm}$ ) have been shown to feed primarily on aquatic and terrestrial insects (Wydoski and Whitney 2003). The largest northern pikeminnow caught during our sampling period was $140 \mathrm{~mm}$. Salmonids were generally larger than predators in our catches; the small sizes and probable mouth gape limitations of predators in our samples likely precludes predation on Chinook and coho salmon, limiting their influence on salmon population dynamics at our study sites.

There are a number of factors that could explain the lack of larger predators in our samples. It is possible that large piscine predators, such as adult northern pikeminnow or largemouth bass, remain more commonly in the main channel of the Columbia River or over coarser substrate (e.g., Martinelli and Shively 1997). Additionally, very small salmonids ( $<50 \mathrm{~mm})$, able to be consumed by gapelimited fishes, were absent due to seasonal effects or the proximity of our sites to suitable spawning habitat. Larger, faster swimming, predators are presumably better able to avoid our gear (Connolly 1994), and therefore may be under-representated in our catches. Similarly, small salmon may have been able to escape by passing through the mesh. Because our catch data represent instantaneous species and size compositions at each site, diel horizontal movement of some larger predators (Jones 2001) were not necessarily accounted for in our sampling scheme. Therefore our catches may have been biased toward smaller, less mobile individuals. Although our data suggest predation on yearling and subyearling salmonids in tidal freshwater areas may be minimal, further sampling, encompassing a greater temporal scale and using different gear types, is necessary to reconcile the relative absence of large predators or very small salmonids in our catches.

\subsubsection{Invasive/Non-native Species}

Introductions of exotic fishes can have large negative impacts on native species, commonly through interspecific competition (McIntosh et al. 1994, Marchetti 1999, Hasegawa and Maekawa 2006), direct predation (Townsend and Crowl 1991, Marsh and Douglas 1997), or alteration of physical habitat (Byers et al 2006). In our samples, $40 \%$ of the fish taxa encountered were nonnative. Two introduced species, banded killifish and bluegill, comprised $22 \%$ of the total combined catch. Because the objectives of this research were not to assess interactions between native and introduced fishes, and despite the prevalence of some exotics in our catches, we can only speculate upon the impacts of nonnative fishes on yearling and subyearling salmonids at our sites.

Diets of the two most abundant introduced species in our catches, banded killifish and bluegill overlap with those of Chinook and coho salmon, particularly in the size ranges we collected (Vile et al. 2004). Banded killifish approximately 31 to $41 \mathrm{~mm}$ in total length have been found to consume aquatic insect larvae, crustaceans, and terrestrial insects; killifish greater than $64 \mathrm{~mm}$ consume similar prey items in addition to larger insects and small mollusks (Wydoski and Whitney 2003). Bluegills 
maintain a relatively constant diet throughout their lives, consisting primarily of aquatic insects. In freshwater habitats, young Chinook and coho salmon have been found to consume small invertebrates; primarily larval aquatic and terrestrial insects (Wydoski and Whitney 2003). Based on the composition of our catches, the distribution of lengths for captured fishes, the putative diets of native and non-native fishes at our sites, and the consistent spatial and temporal overlap in occurrence of the dominant exotic species and salmonids, some degree of interspecific resource competition between introduced fishes and native salmonids may occur at our sites, provided resources are not being partitioned. While our data indicate potential competition, the strength and outcome of these interactions will likely depend upon factors including prey and space availability, fish density, niche plasticity, strength of intraspecific competition, species-specific forage capabilities, and the duration of time migratory salmon spend in tidal freshwater habitats.

Based on the size distributions of exotics in our catches, it appears unlikely that direct predation by nonnative fishes plays a large role in structuring yearling and subyearling salmon populations at our sites. The two most prevalent exotics, banded killifish and bluegill, typically do not consume other fishes (see above). Although larval and small juvenile fish have been found in the diets of bluegill—probably as an artifact opportunistic feeding — to our knowledge, no studies have reported larger salmonids in gut contents of bluegill. The sizes of most Chinook and coho salmon in our samples likely preclude consumption by small, gape-limited exotics. Introduced fish known to be piscivorous as adults, including smallmouth bass, largemouth bass, yellow perch, and brown bullhead, occurred rarely in our catches, and were generally encountered at life stages where invertebrates likely contribute more to diets than fish prey (Wydoski and Whitney 2003).

Although our data indicate predation by exotic species may not limit salmon populations at our sites, several additional factors must be considered. Gear biases may have led to under representation of very small salmonids, able to be consumed by the larger predators we encountered, or larger exotic predators capable of consuming larger salmonids. In addition, our sampling took place during the day, and therefore, diel horizontal movement or crepuscular feeding habits of larger predators were not necessarily accounted for in our sampling scheme. Further sampling, taking into consideration predator movements and ontogenetic feeding variability, will be necessary to elucidate predator-prey interaction between introduced and native fishes in tidal freshwater areas of the Columbia River.

Like competition and direct predation, alteration of physical habitat by exotic fishes can have deleterious impacts on native species (Zambrano et al. 2006). For example, by uprooting or directly consuming aquatic macrophytes, the common carp can limit access to refuge or alter local hydrology leading to shifts in useable/favorable habitat. Additionally, bottom associated exotics, such as the common carp, can limit the foraging capabilities of other fishes by re-suspending fine sediments during feeding (Wydoski and Whitney 2003). In our samples, “ecosystem engineers” (Byers et al 2006) like carp, were rarely encountered. Therefore, the degree to which introduced species are impacting yearling and subyearling salmonids through alteration of physical habitat is likely minimal.

Although assessing specific consequences of fish introductions is beyond the scope of this research, the presence of certain non-salmonine species in our samples indicates potential for negative 
impacts on salmon populations. In addition to those discussed above, other direct and indirect consequences of species introductions, including the alteration of food web dynamics (Eby et al. 2006), the introduction of novel parasites (e.g., Vincent and Font 2003), and predation on gametes (e.g., Crowder 1980), may act to limit salmonid growth and survival at our sites.

\subsubsection{Genetics}

Our genetic analysis indicated that diverse stocks of Chinook salmon occupy habitats within the study area (Table 8). Genetic stock groups from both below (West Cascade Tributaries and Willamette River) and above (Deschutes River, Upper Columbia River, and Snake River) Bonneville Dam were estimated to contribute to the samples. In addition, we found that both fall and spring Chinook salmon were sampled. Estimates of Willamette River fish in our samples are surprising because the Willamette River enters the Columbia River below our study area, meaning fish would have migrated approximately $40 \mathrm{kms}$ upstream to be found in our study area. An alternative explanation is that the fish that we allocated to the Willamette stock were Sandy River spring Chinook salmon. Willamette hatchery stocks have been outplanted extensively in the Sandy River and previous genetic studies have shown that Sandy River spring Chinook are genetically intermediate between the Willamete and Lower Columbia spring run groups (Myers et al. 2006). Additional analysis that includes Sandy River spring run data in the genetic baseline may help with the interpretation of these results.

We summed individual fish assignment probabilities by date to search for temporal patterns in Chinook salmon habitat use (Fig. 34). Sampling in early June produced our largest catches of juvenile Chinook salmon, and also the largest estimated catches of all of the interior Columbia Basin stock groups. In contrast, estimates for spring Chinook salmon from the Willamette River and West Cascade Tributaries were greatest in our late December sampling, which showed the greatest diversity of groups.

Our analysis of first-year samples indicates that genetic data can provide useful information on Chinook salmon use of the study sites. The microsatellite DNA baseline we used for the genetic analysis includes representative populations from all of the major Columbia River Basin stock groups (Waples et al. 2004). It is expected that the multi-agency standardized database supporting the baseline (Seeb et al. 2007) will continue to include more populations providing improved identification for some stock groups.

\subsection{Acoustic Telemetry}

The acoustic telemetry effort during 2007 for the TFM Study was a successful initial attempt to deploy receiving nodes to take advantage of the tens of thousands of JSATS-tagged fish migrating downstream through the study area. The data provided indications of patterns in relative number of detections among locations, run timing, residence time, and migration pathways. However, because detectability at a given node is unknown and likely varied with river stage, especially at the shallower nodes at Old Sandy and Chatham Island, the 2007 data should not be used for quantitative analysis 
beyond the descriptive tables and figures we provided. We offer some actions to address this concern in the recommendations section.

It was not unexpected that the majority of the tagged-fish used the main channel migration pathway given the size of these fish (>90 $\mathrm{mm}$ ) and the pile dikes just upstream on the Oregon shoreline (Figure 40). The pile dikes could serve as guidance devices that shift the horizontal distribution of fish toward the main channel much like a louver array (Bates and Vonsonhaler 1957). Despite this possibility, we observed tagged yearling and subyearling Chinook salmon in the offchannel, shallow water habitat in the vicinity of the Sandy River delta.

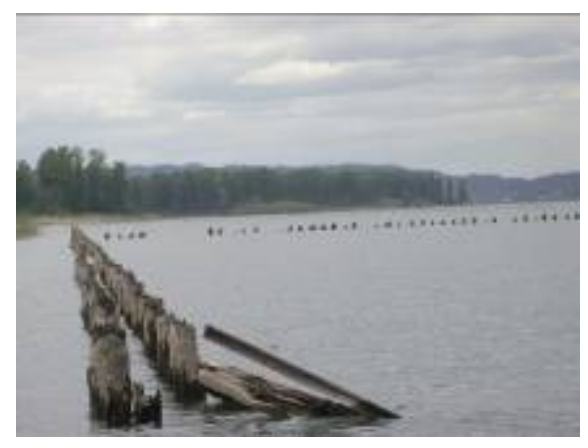

Figure 39. Pile Dikes Upstream of Chatham and Flag Islands (in background).

The presence of tagged fish from Lower Granite Dam in the Snake River indicated that these fish are not all using the lower Columbia River as just a migration corridor. The fact that the subyearling Chinook salmon released at this site had the longest mean residence time in the study area implies potential for these fish to be using the area as rearing habitat. Future diet and prey studies will address habitat use.

The acoustic telemetry data were not consistent with the seine data in terms of relative numbers of salmonids among the sampling sites. The highest number of telemetry detections was at the Reed Island node, whereas the highest mean catch for the beach seine was at Site D near the Sandy River mouth. The inconsistency is probably due to different sample volumes for each technique, i.e., for a given site, the acoustic sample volume typically includes deeper water and a wider area than the seine sample volume.

\subsection{Baseline Data}

The TFM Study results from 2007 are applicable as a baseline, pre-restoration characterization for the purpose of monitoring the effectiveness of the proposed rechannelization of the old Sandy River channel. We will stay abreast of developments as the proposal is maneuvered through the planning and funding process. We are coordinating with the U.S. Forest Service, who is leading the effort. 


\subsection{Conclusions and Recommendations}

\subsection{Fish Sampling and Habitat Characterization}

We have the following conclusions related to Objective 1 -- Provide basic data on habitat and fish community characteristics for yearling and subyearling salmonids in the tidal freshwater reach in the vicinity of the Sandy River delta.

- Our 2007 sampling was sufficient to coarsely characterize fish and fish habitat at our sites and the selected sites were representative of several habitat types present in the tidal freshwater reach.

- $\quad$ Our sites differed in beach slope and presence of submerged aquatic vegetation (SAV), with two sites (B and E) having considerably steeper beach slope (and thus water depth) and more SAV than the other sites.

- Sediment characteristics were similar at all sites, although Site D had a high proportion of larger sediments (gravel) than the other sites.

- Vegetation species were similar throughout the study area, although assemblages at specific sites varied with Sites A and E being characterized by simple bands of a few species and Sites $\mathrm{C}$ and $\mathrm{N}$ consisting of numerous species in small patches. The relationship between elevation and vegetation species occurrence was described for these sites and the arrangement of species at any given site is likely driven by fine-scale changes in topography.

- Water temperature ranges and trends were consistent among sites, with greatest variation during the summer months when local conditions (such as depth and natural seeps) may impact water temperature more than during higher river flow and cooler ambient weather.

- Dissolved oxygen at Site N was considerably lower than at the other sites, which were all similar to each other over time.

- River flow and water level varied considerably throughout our sampling period; this meant that sampling consistently at the same exact location was impractical. Sample locations varied by site and by month depending upon topography of the site.

- The fish community at our shallow, tidal freshwater sampling sites was dominated by juvenile northern pikeminnow, banded killifish, threespine stickleback, bluegill, and peamouth.

- For a given species, the peak abundance varied by site and throughout the sampling period.

- Salmon occurred at all sites and most months except for September and October. 
- There was no statistical difference in the mean size of salmonids sampled at our sites.

- Salmon from multiple stocks were present in our study area, throughout time, with the largest contribution from stocks close to the vicinity of the study area (e.g. West Cascade Tributary and Willamette River). Contributions from other genetic stocks include mainstem and tributaries both upstream and, potentially, downstream of our study area.

- Winter catches of salmonids were dominated by Willamette River stocks (though there may Willamette River stock group fish that were released from Sandy River hatcheries).

- A small portion of Snake River Fall Chinook stock group fish occurred within our study area during the summer months and again in November.

\subsection{Acoustic Telemetry}

We have the following conclusions related to Objective 2 -- Assess feasibility of applying Juvenile Salmon Acoustic Telemetry System (JSATS) technology to determine migration characteristics from upriver of Bonneville Dam through the study area.

- A total of 577 yearling and subyearling Chinook salmon implanted with JSATS transmitters and released at Bonneville and Lower Granite dams had valid detections at the acoustic nodes in the study area. The majority of these detections (545 of 577) were released at Bonneville Dam; the remaining 32 fish were released at Lower Granite Dam.

- Most fish were detected at the Reed Island node, followed by the Gary Island node. Eight fish were present near the node at the old Sandy delta (mouth of the old river channel).

- There were distinct peaks in run timing, with the largest occurring in May 2007, that reflected the pulses of tagged fish released from Bonneville Dam.

- Residence time, as estimated by the mean duration between first and last valid detections, was about $1 \mathrm{~h}$ for subyearlings and $4 \mathrm{~h}$ for yearlings released at Bonneville Dam.

- Migration pathway data indicated that the majority of the JSATS-tagged fish detected at both arrays bracketing the study area- $89 \%$ of the yearlings and $96 \%$ of the subyearlings - used the main river channel. A portion of the tagged fish (9\% yearlings and 3\% subyearlings) apparently used the route between Reed Island and the Washington shore. A fraction of the yearlings and subyearlings, $3 \%$ and $0.3 \%$, respectively, used the route along the Oregon shore at the Sandy delta and Gary Island.

- The 2007 data demonstrate the feasibility of using acoustic telemetry to detect fish for the purpose of investigating migration characteristics in shallow, off-channel habitats in the lower Columbia River. 


\subsection{Recommendations for 2008}

While beach seining proved to be a successful method of capturing fish in our shallow water areas, we offer the following recommendations that will allow us to discriminate sampling bias from variation between sites:

- Although the 2007 sampling provided a coarse look at fish assemblages in shallow water tidal freshwater areas, further sampling over greater spatial and temporal scales would be necessary to reduce the variance in the data.

- Different gear types could be used to evaluate the role of large predators in structuring yearling and subyearling salmon populations.

- Diet analyses should be conducted to shed light on the strength of inter- and intra-specific competition at our sites, and help elucidate potential implications of competitive interactions. Additionally, salmon diet analysis may provide evidence of habitat types these fish are using.

- Comparative evaluation of different gear types and deployment methods will help maximize sampling efficiency; while it is necessary to sample some sites setting the net by boat and some sites by foot, the impacts of the different methods should be evaluated to determine if there are any differences in catch due to the variation in methods.

- Employing PIT-tag detection equipment in the study areas would provide a significant addition to data collection in future years. There are tremendous numbers of PIT-tagged fish released into the Columbia River Basin and the ESA-listed stocks are well represented. As passive monitoring equipment, PIT-tag detectors could operate around the clock and throughout the year to greatly increase the sensitivity of our findings with respect to habitat types and fish use of monitored habitats. This could provide a greater understanding of the habitat needs of listed stocks and should be considered if additional funds become available

We have the following recommendations to improve the acoustic telemetry technique for application in shallow, off-channel habitats:

- Perform drag tests with transmitters at known positions (depth, distance, direction) relative to a given node.

- Deploy a beacon transmitter near some or all of the nodes to monitor receiver performance. During low water, detectability is diminished, but we do not know by how much. A beacon could be used to assess this.

- Research and develop a receiving node for shallow water. This hydrophone should have low side lobes and be 360 deg with a 30 deg horizontal directivity pattern. 
- Disguise and bury tag lines to fixed, autonomous nodes in shallow water to minimize interference from non-project beach-goers.

- Perform a retrospective analysis of the criterion for determining a valid detection event for the data from the off-channel nodes used in this study. 


\subsection{Literature Cited}

Adams, N. S., D. W. Rondorf, S. D. Evans, J. E. Kelley, and R. W. Perry. 1998. Effects of surgically and gastrically implanted radio transmitters on swimming performance and predator avoidance of juvenile Chinook salmon (Oncorhynchus tshawytscha). Can J. Fish. Aquat. Sci. 55:781-787.

Bates, D. W. and R. Vinsonhaler. 1957. Use of louvers for guiding fish. Transactions of the American Fisheries Society 86:38-57.

Beamer, E. and eight co-authors. 2005. Delta and nearshore restoration for the recovery of wild Skagit River Chinook salmon: linking estuary restoration to wild Chinook salmon populations. Appendix D of the Skagit Chinook Recovery Plan. Skagit River System Cooperative, LaConner, WA.

Bisson, P. and nine co-authors. 2000. The Columbia River estuary and the Columbia River basin Fish and Wildlife Program. ISAB 2000-5. Independent Scientific Advisory Board report to the Northwest Power and Conservation Council, Portland, OR

Bjornn, T. C., and D. W. Reiser. 1991. Habitat requirements of salmonids in streams. Pages 83-138 in Influences of forest and rangeland management on salmonid fishes and their habitats. W. R. Meehan, editor. AFS Special Publication 19. American Fisheries Society, Bethesda, MD.

Bottom, D. L. K. K. Jones T. J. Cornwell A. Gray and C. A. Simenstad. 2005a. Patterns of Chinook salmon migration and residency in the Salmon River estuary (Oregon). Estuarine Coastal and Shelf Science 64:79-93.

Bottom, D. L., C. A. Simenstad, J. Burke, A. M. Baptista, D. A. Jay, K. K. Jones, E. Casillas, and M. Schiewe. 2005b. Salmon at river's end: the role of the estuary in the decline and recovery of Columbia River salmon. U.S. Dept. Commer. NOAA Technical Memorandum NMFS-NWFSC68, $246 \mathrm{p}$.

Bottom, D. L., K. K. Jones, and M. J. Herring. 1984. Fishes of the Columbia River estuary. Internal Report. Columbia River Data Development Program. Astoria, Oregon.

Brennan, J. S., K. F. Higgins, J. R. Cordell, and V. A.Stamatiou. 2004. Juvenile salmon composition, timing, distribution, and diet in marine nearshore waters of central Puget Sound in 2001-2002. Final report, King County Department of Natural Resources and Parks, Seattle, WA.

Burke, J. L. 2004. Life histories of juvenile Chinook salmon in the Columbia River estuary, 1916 to the present. Masters Thesis, Oregon State University, Corvallis, OR. 
Byers, J.E., K. Cuddington, C.G. Jones, T.S. Talley, A. Hastings, J.G. Lambrinos, J.A. Crooks, and W.G. Wilson. 2006. Using ecosystem engineers to restore ecological systems. Trends in Ecology and Evolution 21:493-500.

Chapman, D. W. 1966. Food and space as regulators of salmonid populations in streams. American Naturalist 100(913):345-357.

Chapman, D. W. and T. C. Bjornn. 1969. Distribution of salmonids in streams, with special reference to food and feeding. Pages. 153-176 in Symposium on salmon and trout in streams. T. G. Northcote, editor. H. R. MacMillan Lectures in Fisheries. Instititue of Fisheries. University of British Columbia, Vancouver, British Columbia.

Connolly, R.M. 1994. Comparisons of fish catches from a buoyant pop net and a beach seine in a shallow seagrass habitat. Marine Ecology Progress Series. 109:305-309.

Connor, W.P., H.L. Burge, R. Waitt, and T.C. Bjornn. 2002. Juvenile life history of wild fall Chinook salmon in the Snake and Clearwater rivers. North American Journal of Fisheries Management 22:703-712.

Connor, W. P., J. G. Sneva, K. F. Tiffan, R. K. Steinhorst, and D. Ross. 2005. Two alternative juvenile life history types for fall Chinook salmon in the Snake River basin. Trans. Amer. Fish. Soc. 134: 291-304.

Craddock, D. R., T. H. Blahm, and W. D. Parente. 1976. Occurrence and utilization of zooplankton by juvenile Chinook salmon in the lower Columbia River. TAFS 1:72-76.

Crowder, L.B. 1980. Alewife, rainbow smelt and native fishes in Lake Michigan: competition or predation? Environmental Biology of Fishes 5:225-233.

DART. 2008a. DART River Environment Graphics and Text. Data Courtesy of U.S. Army Corps of Engineers, NWD and Grant County PUD. http://www.cbr.washington.edu/dart/river.html. Accessed on January 11, 2008.

DART. 2008b. DART Smolt Index Composite Report. Data Courtesy of Fish Passage Center.http://www.cbr.washington.edu/dart/pass_com.html. Accessed on January 11, 2008.

DART. 2008c. DART Hatchery Releases. Data Courtesy of Fish Passage Center. http://www.cbr.washington.edu/dart/hatch.html. Accessed on January 11, 2008.

Dawley, E. M. and 8 others. 1986. Migrational characteristics, biological observations, and relative survival of juvenile salmonids entering the Columbia River estuary, 1966-1983. Final report, BPA Division of Fish and Wildlife, Portland, OR. 
Durkin, J. 1982. Columbia River coho salmon. In: Kennedy, V.S. (Ed.), Estuarine Comparisons. Academic Press, New York, pp 365-376.

Eby, L. A., W. J. Roach, L. B. Crowder, and J. A. Stanford. 2006. Effects of stocking-up freshwater food webs. Trends in Ecology and Evolution 21:576-584.

ESRI 2004. ArcGIS Version.9. Environmental Systems Research Institute, Inc., Redlands, CA

Fausch, K. D. 1984. Profitable stream positions for salmonids: relating specific growth rate to net energy gain. Canadian Journal of Zoology 62:441-451.

Fausch, K. D. 1993. Experimental analysis of microhabitat selection by juvenile steelhead (Oncorhynchus mykiss) and coho salmon (O. kisutch) in a British Columbia stream. Can. J. Fish. Aquat. Sci.50: 1198-1207.

Fresh, K., E. Casillas, L. Johnson, and D. Bottom. 2005. Role of the estuary in the recovery Columbia River basin salmon and steelhead: an evaluation of selected factors on population viability. U.S. Dept. Commer. NOAA Technical Memorandum NMFS-NWFSC-69.

Harvey, B. C. 1991. Interactions among stream fishes: predator-induced habitat shifts and larval survival. Oecologia 87:29-36.

Hasegawa, K. and K. Maekawa. 2006. The effects of introduced salmonids on two native streamdwelling salmonids through interspecific competition. Journal of Fish Biology 68:1123-1132.

Healey, M. C. 1978. The feeding ecology of chum fry in the Nanaimo estuary. Northeast Pacific Pink and Chum Salmon Workshop; 1978.

Healey, M. C. 1980. Utilization of the Nanaimo River estuary by juvenile Chinook salmon, (Oncorhynchus tshawytscha). Fishery Bulletin 77: 653-668.

Healey, M. C. 1991. Life history of Chinook salmon (Oncorhynchus tshawytscha). Pages 312-393 in C. Groot and L. Margolis, editors, Pacific Salmon Life Histories. UBC Press, Vancouver.

ISRP. 2004. Review of the Lower Columbia River ecosystem monitoing and data management project and the final draft estuary/plume RME plan. ISRP 2004-16. Report to the Northwest Power and Conservation Council, Portland, OR.

ISRP. 2005. Review of Fiscal Year 2006 Proposals for the Estuary and Columbia Cascade. ISRP 2005-17. Report to the Northwest Power and Conservation Council, Portland, OR.

Johnson, G. E., H. D. Diefenderfer, B. D. Ebberts, C. Tortorici, T. Yerxa, J. Leary, J.R. Skalski. 2008. Federal research, monitoring, and evaluation of salmon in the lower Columbia River and 
estuary. PNNL-17330. Report submitted to the Bonneville Power Administration by the Pacific Northwest National Laboratory, Richland, WA.

Jones, T. A. 2001. Seasonal and diel movement of largemouth bass in a South Carolina Stream. Clemson University Master's Thesis.

Kalinowski, S. T., K. R. Manlove, and M. L. Taper. 2007. ONCOR A computer program for genetic stock identification. Department of Ecology, Montana State University, Bozeman, MT. Available at http://www.montana.edu/kalinowski/kalinowski_software.htm

Kirn, R. A., R. D. Ledgerwood, AND A. Jensen. 1986. Diet of subyearling Chinook salmon (Oncorhynchus tshawytscha) in the Columbia River estuary and changes effected by the 1980 eruption of Mount St. Helens. Northwest Science 60 (3):191-196.

Kjelson, M. A., P. F. Raquel, and F. W. Fisher. 1982. Life history of fall-run juvenile Chinook salmon, Oncorhynchus tshawytscha, in the Sacramento-Joaquin estuary, California. In: Kennedy, V.S. (Ed.), Estuarine Comparisons. Academic Press, New York, pp 393-411.

Kukulka, T. and D. Jay. 2003. Impacts of Columbia River discharge on salmonid habitat: 1. A nonstationary fluvial tidal model. Journal of Geophysical Research . 108: 9-1 to 9-20.

LCREP and LCFRB. 2004. Mainstem lower Columbia River and Columbia River estuary subbasin plan. Prepared for the Northwest Power and Conservation Council, Portland, OR.

Ledgerwood, R. D., B. A. Ryan, C. Z. Banks, E. P. Nunallee, B. P. Sandford, S. G. Smith, and J. W. Ferguson. 2003. Detection of PIT-tagged juvenile salmonids in the Columbia River estuary using a surface-trawl detection system, 1999. Report to the U.S. Army Corps of Engineers by NOAA Fisheries, Northwest Fisheries Science Center, Seattle, WA.

Ledgerwood, R. G., E. M. Dawley, L. G. Gilbreath, P. J. Bentley, B. P. Sandford, and M. H. Schiewe. 1991. Relative survival of subyearling Chinook salmon that have passed through the turbines or bypass system of Bonneville Dam Second Powerhouse, 1990. Report to Portland District, U.S. Army Corps of Engineers.

Levy, D. A. and T. G. Northcote. 1982. Juvenile salmon residency in a marsh area of the Fraser River estuary. J. Fish. Res. Bd. Canada. 1982; 39:270-276.

Manel, S., O. Gaggiotti, AND R. S. Waples. 2005. Assignment methods: matching biological questions with appropriate techniques. Trends in Ecology and Evolution 20:136-142.

Marchetti, M. P. 1999. An experimental study of competition between the native Sacramento perch (Archoplites interruptus) and Intoduced bluegill (Lepomis macrochirus). Biological Invasions 1:55-65. 
Marsh, P. C. and M. E. Douglas. 1997. Predation by introduced fishes on endangered humpback chub and other native species in the Little Colorado River, Arizona. Transactions of the American Fisheries Society 126:343-346.

Martinelli, T. L. and R. S. Shively. 1997. Seasonal distribution, movements and habitat associations of northern squawfish in two lower Columbia River reservoirs. Regulated Rivers: Research and Management 13:543-556.

McCabe, G. T. Jr., E. D. Muir, R. L., and J. T. Durkin. 1983. Interrelationships between juvenile salmonids and nonsalmonid fish in the Columbia River estuary. U.S. Bur. Fish., Bull. 81, No. 4, pp. 815-826.

McIntosh, A. R., T. A. Crowl, and C. R. Townsend. 1994. Size-related impacts of introduced brown trout of the distribution of native common river galaxias. New Zealand Journal of Marine and Freshwater Research 28:135-144.

Meyers, K. W. and H. F. Horton. 1982. Temporal use of an Oregon estuary by hatchery and wild juvenile salmon. In: Kennedy, V.S. (Ed.), Estuarine Comparisons. Academic Press, New York, pp 377-392.

Myers, J. M., C. Busack, D. Rawding, A. R. Marshall, D. J. Teel, D. M. Van Doornik, M. T. Maher. 2006. Historical population structure of Pacific salmonids in the Willamette River and lower Columbia River basins U.S. Department of Commerce, NOAA Technical Memo., NMFSNWFSC-73, 311 p.

Murphy, M. L., J. Heifetz, J. F. Thedinga, S. W. Johnson, and K. V. Koski. 1989. Habitat utilization by juvenile Pacific salmon (Oncorhynchus) in the glacial Taku River, southeast Alaska. Canadian Journal of Fisheries and Aquatic Sciences 46:1677-1685.

NOAA (National Oceanic and Atmospheric Administration), National Marine Fisheries Service, Northwest Fisheries Science Center. 2004. Endangered species act, status reviews and listing information. Available at: http://www.noaa.gov/1salmon/salmesa

Pearson W. H., J. R. Skalski, K. L. Sobocinski, M. C. Miller, G. E. Johnson, G. D. Williams, J. A. Southard, and R. A. Buchanan. 2005. A Study of Stranding of Juvenile Salmon by Ship Wakes Along the Lower Columbia River Using a Before/After Design: Before Phase Result. PNNL15400. Prepared for the U.S. Army Corps of Engineers, Portland District, Portland, Oregon by Pacific Northwest National Laboratory, Richland, WA

Pihl, L, A. Cattrijsse, I. Codling, S. Mathieson, D. McLusky, and C. Roberts. 2002. Habitat use by fishes in estuaries and other brackish areas, in: Elliot, M.; Hemingway, K. Fishes in Estuaries. pp. 10-53. 
Puget Sound Estuary Program. 1986. Recommended protocols for measuring conventional sediment variables in Puget Sound. Puget Sound Estuary Program for US EPA, Region 10, Office of Puget Sound, Seattle, WA.

Quinn, T. P. 2005. The Behavior and Ecology Oo Salmon and Trout. University of washington Press. Seattle, Washington.

Ranalla B. and J. L. Mountain. 1997. Detecting immigration by using multilocus genotypes. Proc. Natl. Acad. Sci. USA 94: 9197-9201.

Reimers, P. E. 1968. Social behavior among juvenile fall Chinook salmon. J. Fish. Res. Bd. Canada 25:2005-2008.

Reimers, P. E. 1973. The length of residence of juvenile fall Chinook salmon in Sixes River, Oregon. Research Reports of the Fish Commission of Oregon 4(2): 1-43.

Reimers, P. E. and R. E. Loeffel. 1967. The length of residence of juvenile fall Chinook salmon in selected Columbia River tributaries. Fish Commission of Oregon, Research Briefs 13(1): 5-19.

Reimers, P. E., J. W. Nicholas, D. L. Bottom, T. W. Downey, K. M. Maciolek, J. D. Rodgers, and B. A. Miller. 1979. Coastal salmon ecology project. Annual progress report, federal aid progress reports, fisheries. Oregon Department of Fish and Wildlife, Salem, OR.

Rich, W. H. 1920. Early history and seaward migration of Chinook salmon in the Columbia and Sacramento rivers. U. S. Bur. Fish. Bull. 37:2-73.

Roegner, G. C., D. L. Bottom, A. Baptista, S. Hinton, C. A. Simenstad, E. Casillas, and K. Jones. 2004. Estuarine habitat and juvenile salmon - current and historic linkages in the lower Columbia River and estuary, 2003. Draft report submitted to U.S. Army Corps of Engineers, Portland District by NOAA Fisheries, Northwest Fisheries Science Center, Seattle, WA.

Schreck, C. B., S. P. Clements, M. D. Karnowski, and D. B. Jepsen. 2004. Evaluation of migration and survival of juvenile fall Chinook following transportation, 2003. Draft annual report submitted to U.S. Army Corps of Engineers, Walla Walla District by Oregon State University, Corvallis, OR.

Seeb, L. W., A. Antonovich, M. A. Banks, T. D. Beacham, M. R. Bellinger, S. M. Blankenship, M. R. Campbell, N. A. Decovich, J. C. Garza, C. M. Guthrie III, T. A. Lundrigan, P. Moran, S. R. Narum, J. J. Stephenson, K. T. Supernault, D. J. Teel, W. D. Templin, J. K. Wenburg, S. F. Young, C. T. Smith. 2007. Development of a Standardized DNA Database for Chinook Salmon. Fisheries 32: 540-552. 
Simenstad, C. A., and D. A Jay, and C. R. Sherwood. 1992. Impacts of watershed management of land-margin ecosystems: the Columbia River estuary as a case study. In: R.J. Naiman (Ed.), Watershed Management: Balancing Sustainability and Environmental Change, Springer-Verlag, New York, pp. 266-306.

Simenstad, C. A. and J. R. Cordell. 2000. Ecological assessment criteria for restoring anadromous salmonid habitat in Pacific Northwest estuaries. Ecological Engineering 15:283-302.

Simenstad, C. A. W. J. Kinney, S. S. Parker, E. O. Salo, J. R. Cordell, and H. Buecher. 1980. Prey community structures and trophic ecology of outmigrating juvenile chum and pink salmon in Hood Canal, Washington: A synthesis of three years' studies, 1977-1979. Final Report to WA Dept. Fisheries, Fisheries Research Institute, University of Washington, Seattle, WA. FRI-UW8026.

Simenstad, C.A., J. L. Burke, I. R. Waite, T. D. Counihan and J. R. Hatten. 2005. Lower Columbia River and Estuary Ecosystem Classification: Phase II. Wetland Ecosystem Team, School Aquat. Fish. Sci., Univ. Wash., and U.S. Geol. Surv., Water Res. Div., Ore. Dist. Off., rep. to Lower Columbia River Estuary Partnership, Portland, Oregon. Skalski, J. R., and D. H. McKenzie. 1982. A design for aquatic monitoring programs. Journal of Environmental Management 14:237-251.

Skalski, J. R. and D. H. McKenzie. 1982. A design for aquatic monitoring programs. J. Environ. Manage. 14:237-251.

Small, L. F. ed. 1990. Columbia River: Estuarine System. Progress in Oceanography. Volume 25 (No. 1-4):1-358.

Smouse P. E., R. S. Waples, and J. A. Tworek. 1990. A genetic mixture analysis for use with incomplete source population data. Can. J. Fish. Aquat. Sci. 47:620-634.

Sobocinski, K. L. and A. B. Borde, L. M. Miller, R. M. Thom, and L. M. Tear. 2005. Columbia River estuary habitat monitoring pilot field study and remote sensing analysis. Battelle Marine Sciences Laboratory, Report to the Lower Columbia River Estuary Partnership, Portland, OR.

Taylor, E. B. 1988. Water temperature and velocity as determinants of microhabitats of juvenile Chinook and coho salmon in a laboratory stream channel. Transactions of the American Fisheries Society 117:22-28.

TGO, 2005. Trimble Geomatics Office for Windows. Ver. 1.63. Dayton, OH: Trimble Navigation Ltd.

Thom, R. M. 1987. The biological importance of Pacific Northwest estuaries. Northwest Environmental Journal 3:23-41. 
Thom, R. M. 2000. Adaptive management of coastal ecosystem projects. Ecological Engineering 15:365-362.

Thom, R. M., A. B. Borde, N. R. Evans, C. W. May, G. E. Johnson, and J. A. Ward. 2004. A conceptual model for the lower Columbia River estuary. Final report to the U. S. Army Corps of Engineers by Pacific Northwest National Laboratory, Richland, WA.

Thomas, D. W. 1983. Changes in the Columbia River estuary habitat types over the past century. Columbia River Data Development Program. 51. (Available from Columbia River Estuary Study Taskforce, PO Box 175, Astoria, OR 97103).

Townsend, C. R. and T. A. Crowl. 1991. Fragmented population structure in a native New Zealand fish: an effect of introduced brown trout? Oikos 61:347-354.

United States Geological Survey (USGS). 2008. USGS 14144700 Columbia River At Vancouver, WA. http://nwis.waterdata.usgs.gov/nwis/uv?cb_all_00065=on\&cb_00065=on\&format=html\&period= 31\&site_no=14144700

U.S. Army Corps of Engineers (USACE), Bureau of Reclamation and Bonneville Power Administration. 2005. 2005-2007 Implementation Plan for the Federal Columbia River Power System Endangered Species Act Updated Proposed Action. Portland, OR. Available at http://www.salmonrecovery.gov/implementation.

Van Doornik, D.M., D.J. Teel, D.R. Kuligowski, C.A. Morgan, and E. Casillas. 2007. Genetic analyses provide insight into the early ocean stock distribution and survival of juvenile coho salmon (Oncorhynchus kisutch) off the coasts of Washington and Oregon. North American Journal of Fisheries Management 27:220-237.

Vile, J. S., T. A. Friesen, and M. J.Reesman. 2004. Diets of juvenile salmonids and introduced fishes of the lower Willamette River, in Biology, behavior, and resources of resident and anadromous fish in the lower Willamette River. T. A. Friesen, editor. Final Report of Research, 2000-2004, City of Portland, Bureau of Environmental Services, Endangered Species Act Program, Portland, OR.

Vincent, V.G . and W. F. Font. 2003. Host specificity and population structure of two exotic helminthes Camallanus cotti (Nematoda) and Bothriocephalus acheilognathi (Cestoda), parasitizing exotic fishes in Waianu Stream, O’Ahu Hawai’i. Journal of Parisitology 89:540 544.

Waples, R. S. 1991. Pacific salmon, Oncorhynchus spp. and the definition of "species" under the Endangered Species Act. U.S. National Marine Fisheries Service Review 53(3): 11-22. 
Waples, R. S., and D. J. Teel, J. M. Myers and A. R. Marshall. 2004. Life-history divergence in Chinook salmon: Historic contingency and parallel evolution. Evolution 58: 386-403

Weitkamp, L. A. 1994. Effect of dams on Columbia River estuarine environment with special reference to salmonids. National Marine Fisheries Service, Seattle WA.

Werner, E. E., and J. F. Gilliam. 1984. The ontogenetic niche and species interactions in sizestructured populations. Annual Review of Ecology and Systematics 15:393-425.

Williams, R. 2007. Summary of the Northwest Power and Conservation Council's Science-Policy Exchange. September 12-13, 2007, Portland, OR. Available at http://www.nwcouncil.org/news/.

Wydoski, R. S. and R. R. Whitney. 2003. Inland fishes of Washington, $2^{\text {nd }}$ edition. University of Washington Press, Seattle, Washington.

Zar, J. H. 1999. Biostatistical Analysis. Fourth edition. Prentice-Hall, Inc., Upper Saddle River, New Jersey, USA.

Zambrana, L., E. Martinez-Meyer, N. Menezes, and A.T. Peterson. 2006. Invasive potential of common carp (Cyprinus carpio) and Nile tilapia (Oreochromis niloticus) in American freshwater systems. Canadian Journal of Fisheries and Aquatic Sciences 63:1903-1910. 


\section{Appendix A: Relationships to Other Programs and Projects}

The study is germane to the three main Columbia River regional salmon research/restoration programs and multiple projects in the region. While none of the programs prioritized explicit RME efforts in the tidal freshwater portion of the LCRE, such RME is considered a high priority because the study area is in the migration corridor for juvenile salmon, potentially provides critical feeding, rearing and refuge for salmonids, and has been damaged considerably such that restoration in this region could result in enhanced salmonid fitness and survival.

\section{Northwest Power and Conservation Council's Fish and Wildlife Program (FWP) and}

\section{Lower Columbia River and Estuary Subbasin Plans}

The Columbia Basin Fish and Wildlife Program (NPCC 2000) calls for consideration of estuarine and ocean conditions in implementation of the FWP. This policy was supported by the Independent Scientific Advisory Board (Bisson et al. 2000). Also, the FY02-FY04 provincial solicitation process for the LCRE resulted in several millions of dollars of habitat restoration and monitoring projects in the LCRE.

The Mainstem Lower Columbia River and Columbia River Estuary Subbasin Plan (LCREP and LCFRB 2004), also referred to as the "Separate Bi-State Plan", contains a "physical objective" to “...Develop an understanding of emigrating salmonid juvenile life history diversity....in the lower mainstem, the Western Oregon tributaries, the estuary and the plume.” In addition this subbasin plan includes the following working hypotheses (from Table ES1-2) that are relevant to our proposed study:

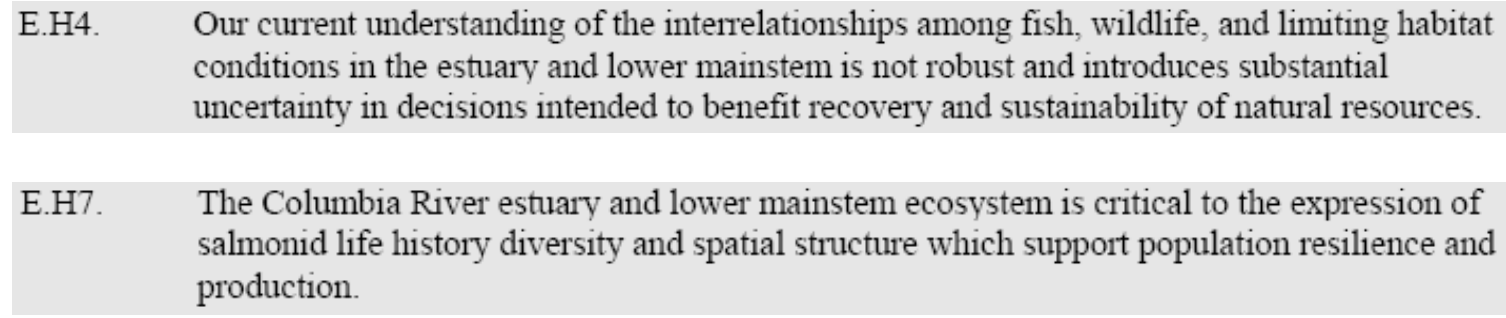
conditions in the estuary and lower mainstem is not robust and introduces substantial uncertainty in decisions intended to benefit recovery and sustainability of natural resources.

E.H7. The Columbia River estuary and lower mainstem ecosystem is critical to the expression of salmonid life history diversity and spatial structure which support population resilience and production.

E.H12 Habitat restoration efforts are capable of significantly improving conditions for fish and wildlife species in the Columbia River estuary and lower mainstem.

In November 2004, LCREP released the Supplement to the Mainstem Lower Columbia River and Columbia River Estuary Subbasin Plan (LCREP 2004b). Also known as the "Management Plan Supplement”, this document (p. 2-1) espoused a supporting strategy to manage uncertainty through research and monitoring; it specifically noted the lack of data for the mainstem lower river, i.e., tidal freshwater. 
In December 2004, LCFRB published the Lower Columbia Salmon Recovery and Fish and Wildlife Subbasin Plan (LCFRB 2004). Strategy E.S5 (p. 6-28) says: "Improve understanding of how salmonids utilize estuary and lower mainstem habitats and develop a scientific basis for estimating species responses to habitat quantity and quality.” Furthermore, physical objective Sa.PO.7 (p. A224) states: "Develop an understanding of emigrating juvenile salmonid life history diversity and habitat use in the lower mainstem, estuary, and plume.”

In November 2005, the NPCC released the Draft Columbia River Basin Research Plan (NPCC 2005). This plan lists key management questions, including the following (p. 44): "What is the ecological importance of the Columbia River estuary [defined to be the reach from Bonneville Dam to the mouth] and oceanic plume to the viability and recovery of salmonid populations in the Columbia Basin?" And, one of the research priority questions (p. 49 is: "Which estuarine habitat types should have the highest priority for restoration?”

In conclusion, our study furthered the goals and objectives of the NPCC's Fish and Wildlife Program and the LCRE Subbasin Plans by providing basic scientific data on habitat usage by juvenile salmonids in the tidal freshwater reach that managers could use to prioritize habitat restoration projects to implement the LCRE Subbasin Plans and to mitigate for the effects of the federal hydrosystem.

\section{NOAA Fisheries/Action Agencies’ ESA Consultation on Federal Columbia River Power System Operations}

The NOAA Fisheries' Biological Opinion on Operation of the FCRPS (NOAA 2004) identified lower Columbia River habitats as important to the continued existence of the Snake River fall Chinook salmon evolutionarily significant unit. They said (NOAA 2004, p.E3-9) “...Snake River fall Chinook salmon likely gain greater [than chum salmon] beneficial use of tidal freshwater habitat in the region between Bonneville Dam and RM 40.” The Action Agencies' Implementation Plan for the Updated Proposed Action (USACE et al. 2005) specifically supported the habitat restoration effort currently underway at the Sandy River delta. UASCE et al. (2005) said, "The Corps and BPA will protect, enhance, and restore shallow water and wetland habitats along and adjacent to the mainstem Columbia River below Bonneville Dam and tidal wetlands.” Regarding research and monitoring, USACE et al. (2005) stated (p. 54) that the near-term target included “...develop estuary habitat pilot status monitoring and participate in regional coordination activities.” Near and long-term actions include, “...monitor presence/absence and population identity of juvenile salmonids in the upper reaches of the estuary...” and (p. 55) “... determine the significance of the lower river and estuary...to listed salmonids.” Furthermore, the Action Agencies specifically stated (Table 24, p. 57) that they would fund a project to “... determine the presence through time of subyearling salmon at the Sandy River delta in the tidal freshwater reach on the Columbia River and to integrate these results with data from other selected estuary monitoring studies.” A similar decree is under negotiation for yearling salmonids from the Upper Columbia spring Chinook and steelhead populations. 
BPA (2005) provide guidance on key management and subordinate questions in a matrix structure for RME. With respect to the LCRE, the study is applicable to the following questions (p. 9-11): "What are the status/trends in the attributes of the [L]CRE, plume, and ocean ecosystems?" A subordinate question to the previous management question is: "What are estuary fish population properties, especially with respect to listed salmonids?” Another management question is: "What are the limiting factors or threats in the estuary preventing the achievement of desired habitat, fish, or wildlife performance objectives...?” A pertinent subordinate question is: "What is the ecological importance of the Columbia River estuary and oceanic plume to the viability and recovery of salmonid populations in the Columbia Basin?”

In conclusion, the study furthered the ESA-related goals and objectives of NOAA Fisheries and the Action Agencies by specifically addressing the mandates listed in the previous paragraphs.

\section{U.S. Army Corps of Engineers' Research, Restoration, and Channel Improvement Programs in the LCRE}

The USACE (Corps) conducts research on fish passage at its eight mainstem dams on the lower Snake and Columbia rivers under the auspices of the Anadromous Fish Evaluation Program (AFEP) and funded through the Columbia River Fish Mitigation Project. The purpose of this research program is to identify and implement means to improve the survival of juvenile and adult salmonids migrating through the hydrosystem. This program also covers research in the LCRE under a special provision of a Water Resources Development Act (WRDA).

Various other WRDAs authorize the Corps to restore aquatic habitats. Section 1135 of WRDA 1986 and Section 206 of WRDA 1996 provide the authority to modify existing Corps projects and non-Corps projects, respectively, to restore the environment. Section 536 of WRDA 2000 provides authority for the Corps to carry out ecosystem restoration projects in the LCRE. Section 306 of WRDA 1990 authorizes a General Investigations Study to develop environmental restoration in the LCRE.

The USACE Portland District is undertaking the Columbia River Channel Improvement Project to deepen the river between Portland and the ocean to pass deep draft cargo vessels. This project includes research on juvenile salmon stranding (see more details in Section D) related to ship passage in the LCRE and restoration project monitoring. The study furthered the goals and objectives of the USACE by providing basic scientific data on habitat usage by subyearling salmon in the tidal freshwater reach that USACE managers could use to further justify and prioritize habitat restoration projects related to Water Resource Development Acts and the Channel Improvement Project.

\section{Other Projects}

The relationship of our study to relevant projects in the LCRE is described in Table A1. After the table, we describe some of the more important inter-project relationships for the TFM Study. 
Table A 1. Interrelationships among BPA- and Corps-funded Projects Germaine to this Study. Entries in alphabetical order by project title.

\begin{tabular}{|c|c|c|c|c|c|}
\hline Project Title & Number & Funding & Sponsor & Description & Relationship \\
\hline $\begin{array}{l}\text { Acoustic } \\
\text { Tracking for } \\
\text { Estimating } \\
\text { Ocean Survival }\end{array}$ & $\begin{array}{l}\text { BPA 2003- } \\
114-00\end{array}$ & BPA & Kintama & $\begin{array}{l}\text { Acoustic telemetry } \\
\text { evaluation of juvenile } \\
\text { salmon migration } \\
\text { patterns }\end{array}$ & $\begin{array}{l}\text { We will inform these } \\
\text { researchers, who are using a } \\
\text { different acoustic telemetry } \\
\text { system than we propose. } \\
\text { The two approaches are } \\
\text { complementary, designed to } \\
\text { answer different questions } \\
\text { in different environments. }\end{array}$ \\
\hline $\begin{array}{l}\text { Alternative } \\
\text { Smolt } \\
\text { Transportation } \\
\text { Methods }\end{array}$ & $\begin{array}{l}\text { Corps TPE- } \\
\text { W-06-02 }\end{array}$ & USACE & $\begin{array}{l}\text { PNNL } \\
\text { and } \\
\text { NOAA } \\
\text { Fisheries }\end{array}$ & $\begin{array}{l}\text { Acoustic telemetry } \\
\text { evaluation of barged } \\
\text { fish released at } \\
\text { different locations in } \\
\text { the LCRE }\end{array}$ & $\begin{array}{l}\text { We will use tagged fish } \\
\text { from this study, if present }\end{array}$ \\
\hline $\begin{array}{l}\text { Collaborative } \\
\text { Systemwide } \\
\text { M\&E Program } \\
\text { (CSMEP) }\end{array}$ & $\begin{array}{l}\text { BPA 2003- } \\
036-00\end{array}$ & BPA & CBFWA & $\begin{array}{l}\text { Columbia basin-wide } \\
\text { coordination of M\&E }\end{array}$ & $\begin{array}{l}\text { We will inform CSMEP of } \\
\text { our efforts }\end{array}$ \\
\hline $\begin{array}{l}\text { Crims Is. } \\
\text { Monitoring }\end{array}$ & Unk. & USACE & USGS & $\begin{array}{l}\text { Action effectiveness } \\
\text { monitoring at the } \\
\text { Crims Is. restoration } \\
\text { project (rkm 88) }\end{array}$ & $\begin{array}{l}\text { We will integrate our results } \\
\text { with those from Crims Is. }\end{array}$ \\
\hline $\begin{array}{l}\text { Cumulative } \\
\text { Ecosystem } \\
\text { Effects of } \\
\text { Habitat } \\
\text { Restoration }\end{array}$ & $\begin{array}{l}\text { Corps EST- } \\
\text { P-04-04 }\end{array}$ & USACE & $\begin{array}{l}\text { PNNL } \\
\text { and } \\
\text { NOAA } \\
\text { Fisheries }\end{array}$ & $\begin{array}{l}\text { Development of } \\
\text { innovative ecological } \\
\text { methods through } \\
\text { focused field studies }\end{array}$ & $\begin{array}{l}\text { We will inform this study of } \\
\text { our telemetry monitoring } \\
\text { protocols for action } \\
\text { effectiveness research and } \\
\text { vice versa }\end{array}$ \\
\hline $\begin{array}{l}\text { Current and } \\
\text { Historic } \\
\text { Biophysical } \\
\text { Linkages in the } \\
\text { Estuary }\end{array}$ & $\begin{array}{l}\text { BPA 2003- } \\
010-00, \\
\text { Corps EST- } \\
\text { P-02-02 }\end{array}$ & $\begin{array}{l}\text { BPA and } \\
\text { USACE }\end{array}$ & $\begin{array}{l}\text { NOAA } \\
\text { Fisheries }\end{array}$ & $\begin{array}{l}\text { Fundamental } \\
\text { research re: juvenile } \\
\text { salmon in rkm 0-56 }\end{array}$ & $\begin{array}{l}\text { We will integrate our results } \\
\text { with these. On July 10, } \\
\text { 2006, Mr. Johnson and Dr. } \\
\text { Casillas, project leader for } \\
\text { the NMFS consortium, } \\
\text { specifically agreed to } \\
\text { collaborate and exchange } \\
\text { data between their } \\
\text { respective research efforts. }\end{array}$ \\
\hline $\begin{array}{l}\text { Ecosystem } \\
\text { Monitoring - } \\
\text { Habitat and } \\
\text { Water Quality }\end{array}$ & $\begin{array}{l}\text { BPA 2003- } \\
007-00\end{array}$ & BPA & LCREP & $\begin{array}{l}\text { Status monitoring at } \\
\text { selected sites in the } \\
\text { LCRE (e.g., habitat } \\
\text { mon. at rkm } 112 \text { and } \\
152 \text { in } 2005 \text {, but no } \\
\text { fish sampling except } \\
\text { for purpose of a } \\
\text { toxics objective }\end{array}$ & $\begin{array}{l}\text { We will coordinate and } \\
\text { integrate our study with this } \\
\text { one; we will share some } \\
\text { sampling sites so that } \\
\text { habitat characteristics will } \\
\text { be measured }\end{array}$ \\
\hline $\begin{array}{l}\text { Estuary/Ocean } \\
\text { RME Subgroup }\end{array}$ & $\begin{array}{l}\text { BPA 2002- } \\
077-00\end{array}$ & BPA & PNNL & $\begin{array}{l}\text { Facilitate the } \\
\text { Estuary/Ocean } \\
\text { Subgroup for federal } \\
\text { RME and help } \\
\text { develop the Estuary }\end{array}$ & $\begin{array}{l}\text { We will provide monitoring } \\
\text { data to help design sampling } \\
\text { for the Estuary RME Plan } \\
\text { and we will implement } \\
\text { applicable elements of the }\end{array}$ \\
\hline
\end{tabular}




\begin{tabular}{|c|c|c|c|c|c|}
\hline Project Title & Number & Funding & Sponsor & Description & Relationship \\
\hline & & & & RME Plan & $\begin{array}{l}\text { Estuary RME Plan when it } \\
\text { is revised in } 2006\end{array}$ \\
\hline $\begin{array}{l}\text { Juvenile Salmon } \\
\text { Stranding from } \\
\text { Ship Traffic }\end{array}$ & Unk. & USACE & PNNL & $\begin{array}{l}\text { Beach seining for a } \\
\text { study of stranding at } \\
\text { sites at rkm 82, 99, } \\
155\end{array}$ & $\begin{array}{l}\text { We will integrate our results } \\
\text { with these and may use fish } \\
\text { sampling data for } \\
\text { comparison }\end{array}$ \\
\hline $\begin{array}{l}\text { Juvenile Salmon } \\
\text { Survival in the } \\
\text { Estuary }\end{array}$ & $\begin{array}{l}\text { Corps EST- } \\
\text { P-02-01 }\end{array}$ & USACE & $\begin{array}{l}\text { NOAA } \\
\text { Fisheries } \\
\text { and } \\
\text { PNNL }\end{array}$ & $\begin{array}{l}\text { Acoustic telemetry } \\
\text { study of reach } \\
\text { survival between } \\
\text { BON and the mouth } \\
\text { of yearling and } \\
\text { subyearling } \\
\text { salmonids }\end{array}$ & $\begin{array}{l}\text { We will sample tagged fish } \\
\text { from this study, if present at } \\
\text { our study area }\end{array}$ \\
\hline $\begin{array}{l}\text { LCRE Habitat } \\
\text { Mapping }\end{array}$ & $\begin{array}{l}\text { BPA 2002- } \\
012-00\end{array}$ & $\begin{array}{l}\text { BPA and } \\
\text { USACE }\end{array}$ & LCREP & $\begin{array}{l}\text { Remote sensing } \\
\text { mapping project, } \\
\text { Landsat } 7 \text { TM and } \\
\text { CASI imagery }\end{array}$ & $\begin{array}{l}\text { We will consult maps from } \\
\text { this project }\end{array}$ \\
\hline $\begin{array}{l}\text { LCRE Habitat } \\
\text { Restoration }\end{array}$ & $\begin{array}{l}\text { BPA 2003- } \\
011-00\end{array}$ & BPA & LCREP & $\begin{array}{l}\text { On-the-ground } \\
\text { projects passing a } \\
\text { technical vetting }\end{array}$ & $\begin{array}{l}\text { We will inform this project } \\
\text { of our findings }\end{array}$ \\
\hline $\begin{array}{l}\text { Pacific } \\
\text { Northwest } \\
\text { Aquatic } \\
\text { Monitoring } \\
\text { Partnership }\end{array}$ & $\begin{array}{l}\text { BPA 2004- } \\
002-00\end{array}$ & BPA & USGS & $\begin{array}{l}\text { Coordination of the } \\
\text { regional RME } \\
\text { process; includes } \\
\text { PNAMP estuary } \\
\text { workgroup }\end{array}$ & $\begin{array}{l}\text { We will inform this effort of } \\
\text { our work }\end{array}$ \\
\hline $\begin{array}{l}\text { Pilot Monitoring } \\
\text { in Wenatchee } \\
\text { and Grande } \\
\text { Ronde Basins }\end{array}$ & $\begin{array}{l}2003-017- \\
00\end{array}$ & BPA & NOAA & $\begin{array}{l}\text { Pilot RME } \\
\text { monitoring projects } \\
\text { in tributary habitats }\end{array}$ & $\begin{array}{l}\text { We will consult with these } \\
\text { researchers regarding RME }\end{array}$ \\
\hline $\begin{array}{l}\text { Sandy River } \\
\text { Delta Habitat } \\
\text { Restoration }\end{array}$ & $\begin{array}{l}\text { BPA 1999- } \\
025-00\end{array}$ & $\begin{array}{l}\text { BPA and } \\
\text { USACE }\end{array}$ & USFS & $\begin{array}{l}\text { On-the-ground } \\
\text { restoration at the } \\
\text { proposed study site }\end{array}$ & $\begin{array}{l}\text { We will coordinate, } \\
\text { integrate, and inform this } \\
\text { key project about our work }\end{array}$ \\
\hline $\begin{array}{l}\text { Technical Basis } \\
\text { for Prioritization } \\
\text { of Habitat } \\
\text { Restoration } \\
\text { Projects }\end{array}$ & $\begin{array}{l}\text { Part of BPA } \\
2003-011- \\
00\end{array}$ & $\begin{array}{l}\text { BPA and } \\
\text { State of } \\
\text { Oregon }\end{array}$ & LCREP & $\begin{array}{l}\text { Research to develop } \\
\text { a technical basis for } \\
\text { restoration project } \\
\text { selection }\end{array}$ & $\begin{array}{l}\text { We will inform this effort of } \\
\text { our work, which will be } \\
\text { useful in their prioritization } \\
\text { process }\end{array}$ \\
\hline
\end{tabular}

The study has working relationship with the Estuary/Ocean RME Subgroup project (BPA Project 2002-077-00) and the Plan for Research, Monitoring, and Evaluation of Salmon in the Columbia River Estuary. Data from this study will inform the sampling designs for the LCRE status monitoring program and action effectiveness research. The RME Plan developed by the subgroup will provide the framework for a monitoring program that the study will be part of.

The Tidal Freshwater Monitoring Study is strongly related to Estuary Partnership's LCRE Ecosystem Monitoring project (BPA project 2003-064-00, Table 1). This project includes a largescale effort to develop a new hydrogeomorphic-based habitat classification system and apply it to 
map aquatic habitats in the entire LCRE. As the habitat classification scheme is coupled with habitat and water quality data within this project, the array of potential habitats in the tidal freshwater area will be quantified and mapped. The Ecosystem Monitoring project will provide the context for the landscape containing the Sandy River delta study area. In turn the TFM study will provide useful data on fish presence/absence at various habitat complexes in the vicinity of the Sandy River delta.

The Sandy River Delta Habitat Restoration project (BPA project 1999-025-00) will utilize the fish and ancillary data collected as part of the study. We will share our data and coordinate our efforts with theirs. Information from the ongoing restoration project, however, will be useful to our study, especially when used in conjunction with information from the LCRE Ecosystem Monitoring project. The tie in with the Sandy River restoration effort is limited at this time because restoration to date has concerned re-vegetation. If and when the tidal reconnection project happens, we will coordinate with the appropriate parties.

The relationship between our study and the USACE estuary survival project (EST-P-02-01, Table 1) is important. During 2000-2005, the USACE funded NOAA Fisheries and PNNL to develop a miniaturized acoustic tag and acquisition hardware. This acoustic telemetry technology is called the Juvenile Salmon Acoustic Telemetry System (JSATS). The USACE-funded research continued in FY07, because improving survival rates for subyearling salmon passing through the federal hydrosystem is a high priority. The large USACE effort involves focused research at mainstem hydropower dams and project, reach, and system-wide survival estimates on a species-specific basis. To estimate survival rates, juvenile salmon are marked with acoustic tags, released in the Snake River and other locations, and detected at downstream hydrophones arrays, such as at the mouth of the Columbia River. For example, USACE studies in 2007 tagged over 20,000 juvenile salmonids. Since most of these fish migrated through the Sandy River and vicinity, there was important opportunity to perform feasibility work on acoustic telemetry monitoring protocols in shallow tidal freshwater. As an Action Agency, the USACE agreed to collaborate on applying its acoustic telemetry technology to the proposed study. Specifically, the USACE allowed us to listen for fish tagged for their purposes.

Another related effort using acoustic telemetry technology is the project Acoustic Tracking for Estimating Ocean Survival (BPA project 2003-014-00, Table 1). This project is using equipment manufactured by Vemco to study yearling salmon migration patterns along the continental shelf in the Northeast Pacific Ocean. By necessity, the VEMCO tags have long battery-life and are therefore relatively large. The JSATS technology was designed to provide a way to estimate survival rates in subyearling Chinook salmon (at this time, the min. size fish tagged is $90 \mathrm{~mm}$ ). Thus, the two technologies are complementary, designed to answer different questions in different environments. 


\title{
Appendix B: Statistical Synopsis
}

\author{
Statistical Design for \\ The Sandy River Tidal Water Monitoring Project
}

\author{
Prepared for: \\ Gary Johnson \\ Kathryn Sobocinski \\ Battelle Pacific Northwest National Lab \\ 620 SW Fifth Avenue, Suite 810 \\ Portland, Oregon 97204 \\ Prepared by: \\ John R. Skalski \\ Columbia Basin Research \\ School of Aquatic and Fishery Sciences \\ University of Washington \\ 1325 Fourth Avenue, Suite 1820 \\ Seattle, Washington 98101
}

14 November 2007 (reformatted by GEJ, 1/17/08) 


\section{Introduction}

This monitoring study in the vicinity of the Sandy River Delta will provide needed information for the design of future large-scale monitoring programs in the tidal freshwater environment of the Columbia River. The study will provide estimates of variance components needed to determine sample sizes for consummate investigations and an evaluation of the sampling gear used to monitor the fish populations. This may include alternative beach seines as well as fish tagging techniques. In addition, events at the Sandy River Delta may also permit an assessment of a mitigation project aimed at reconnecting the old river channel to the Columbia River using a beforeafter, control-impact (BACI) design. This report describes the sampling design and intended statistical analyses of the data.

\section{Sampling Scheme}

\section{Site Locations}

Six fixed-location sampling sites will be monitored over the course of the study. The sites are describes as follows:

- Site A: North shore of Reed Island in the Washington State side of the Columbia River

- Site B: Beach side of Chatham Island, upshore of Sandy River Delta on the Oregon State side of the Columbia River

- Site C: Near the mouth of the old channel at Sandy River Delta on the Oregon State side of the Columbia River

- Site D: Near the mouth of the current channel at Sandy River Delta on the Oregon State side of the Columbia River

- Site E:: West shore of Gary Island on the Oregon state side of the Columbia River

- Site N: At the current dam in the old channel of the Sandy River Delta

- Site A, C, D and E represent Columbia River channel sites as opposed to Sites B and N, which are more off-channel in nature.

Regarding a BACI design to assess the effects of rechannelization, Sites B and E are control sites, while Sites $\mathrm{C}$ and $\mathrm{N}$ are within the zone of potential impact from the restoration project. Suggested pairings are $\mathrm{C}$ with $\mathrm{E}$ and $\mathrm{N}$ with $\mathrm{B}$. Sites $\mathrm{C}$ and $\mathrm{E}$ are open channel sites, where $\mathrm{C}$ may be affected when the old channel is reopened. Sites N and B are backwater or off-channel sites, where $\mathrm{N}$ will be affected when the old channel is reopened. Hence, there are two control-impact pairs that can be monitored pre- and post-rechannelization. Sites A and D will not be active components of the BACI design, but will serve as references for Columbia River fish community composition.

Sampling Scheme

Monthly sampling will occur throughout the year. Once each month, the fixed monitoring sites will be sampled in random order over a two-day consecutive period. At each site, two replicate seine samples will be collected from the designated sampling station. All fish collected will be identified to species (or genus if species identification not possible) and length recorded. The second seine set will be performed at least $1 / 2 \mathrm{~h}$ after the first to allow the fish population to reestablish itself so independent index data on fish densities can be collected. Auxiliary information on water quality, bathymetry, 
vegetation assemblage, and position along the river edge will be collected concurrent with the seining data.

\section{Data Analysis}

\section{Descriptive Data}

Information on seasonal species composition and abundance will be assembled and presented in tabular and graphical form. Fish relative abundance will be summarized, both by species (i.e., yearling Chinook salmon, coho salmon, etc) as well as grouped by family (e.g., salmonids) and functional groups (e.g. cold-water vs. warm-water species, predators, etc.). For salmonids, hatchery vs. assumed wild (i.e., adipose fin clipped or not) counts over the seasons will be examined. Species composition and abundance trends will be compared and contrasted across sites and habitats (e.g., main channel vs. backwater).

\section{Variance Component Estimation}

Considering the replicate beach seines within a site as repeated measures of the same local response (i.e., measurement or sampling error), the data within a survey period can be used to estimate spatial variability $\left(\sigma_{s}^{2}\right)$ and average measurement error $\left[\right.$ i.e., $\left.\widehat{\operatorname{Var}}\left(\hat{x}_{i} \mid x_{i}\right)\right]$ by habitat type. For example, consider $k$ replicate sites within a habitat and $n$ replicate samples per site, then a oneway ANOVA can be used to estimate the variance components as follows:

\begin{tabular}{lllll}
\hline Source & DF & SS & MS & $\mathrm{E}(\mathrm{MS})$ \\
\hline Total $_{\text {Cor }}$ & $n k-1$ & SSTOT $_{\text {Cor }}$ & & \\
Between sites & $k-1$ & SST & MST & $\overline{\operatorname{Var}\left(\hat{x}_{i} \mid x_{i}\right)}+n \sigma_{S}^{2}$ \\
Within sites & $n k-k$ & SSE & MSE & $\overline{\operatorname{Var}\left(\hat{x}_{i} \mid x_{i}\right)}$ \\
\hline
\end{tabular}

From the one-way ANOVA table above, average measurement error is estimated by MSE and spatial variance $\left(\sigma_{S}^{2}\right)$ by the expression

$$
\hat{\sigma}_{S}^{2}=\frac{\mathrm{MST}-\mathrm{MSE}}{n},
$$

where $k$ = number of sites and $n=$ number of replicate samples per locations (e.g., 2).

In many biological systems, particularly for abundance data, the variance increases as the mean abundance increases. In such cases, the variance tends to follow the negative binomial rule where

$$
\sigma_{S}^{2}=\mu+\frac{\mu^{2}}{c},(2)
$$

where $\mu=$ mean abundance and $c$, negative binomial coefficient. In other cases where the data are log-normally distributed, such as catch-per-unit-effort data, 


$$
\sigma_{S}^{2}=c \mu^{2}
$$

in other words, the coefficient of variation $(\sigma / \mu)$ is constant. Repeated sampling across the seasons and habitats will be used to determine the best characterization for $\sigma_{S}^{2}$ for subsequent sample size calculations. Similar mean-variance relationships often hold for measurement error as well. Based on the most appropriate variance-to-mean relationship, data will be pooled across sampling events to obtain more precise estimates of the variance components for subsequent sample size calculations. Estimates of Correlation

The degree of correlation between sites over time will be important in any monitoring program that uses a paired design. This correlation within a habitat category can be estimated using the intraclass correlation coefficient estimated (Zar 1999:404-407) from, again, a one-way ANOVA.

Consider the case of $k$ sites sampled over 4 seasons, the one-way ANOVA can then be constructed as follows:

\begin{tabular}{lllll}
\hline Source & DF & SS & MS & E(MS) \\
\hline Total $_{\text {Cor }}$ & $4 k-1$ & & & \\
Seasons & 3 & SST & MST & $\sigma^{2}+\sigma_{T}^{2}$ \\
Error & $4 k-4$ & SSE & MSE & $\sigma^{2}$ \\
\hline
\end{tabular}

Then the intra-class correlation $\left(\rho_{I}\right)$ is estimated by the variance components where

$$
\hat{\rho}_{I}=\frac{\hat{\sigma}_{T}^{2}}{\hat{\sigma}^{2}+\hat{\sigma}_{T}^{2}} .
$$

Following the analysis of previous Section 3.2, the estimate $\hat{\sigma}^{2}$ in Eq. (4) can be partitioned into natural variation $\left(\sigma_{S}^{2}\right)$ and average measurement error $\left(\overline{\operatorname{Var}\left(\hat{x}_{i} \mid x_{i}\right)}\right)$, leading to a more accurate estimate of the actual temporal correlation

$$
\hat{\rho}_{2}=\frac{\hat{\sigma}_{T}^{2}}{\hat{\sigma}_{S}^{2}+\hat{\sigma}_{T}^{2}} \text {. (5) }
$$

Patterns in the correlations between different habitats and response variables will be examined. In paired-plot designs, those responses with the highest correlation will tend to have the smallest overall error variance and have a better opportunity to detect change over time.

Temporal conditions between years important in the ability to detect time trends and important in optimally designing rotational studies will be calculated using the standard Pearson correlation coefficient.

BACI Analysis

Should rechannelization occur during the course of this study, a BACI analysis (Skalski and McKenzie 1982) could be performed to assess the effects of that activity on local fish populations. The expectation of the mitigation action is to decrease non-native warm-water species (e.g., killifish, largemouth bass, and bluegill) densities and increase the abundance of salmonids and other native 
resident fishes. Therefore, separate analyses should be performed to assess both expected losses and gains in fish relative abundance.

It is recommended that only seasonal data be used to help minimize the potential effects of autocorrelation on the repeated measures through time. Using the log of the impact-control ratios should also minimize any perceived autocorrelations.

For purposes of illustration, consider the scenario of 4 seasonal surveys, 2 years before and 2 years after the restoration action at the old Sandy River Delta channel. At each survey occasion, the 2 impact-control ratios of sites (i.e., C/D and N/B) are measured. The result will be 32 estimates of impact/control ratios which will be analyzed using a normal error, log-link,generalized linear model (GLM). The anticipated degree-of-freedom table for the analysis is illustrated in Table B.1.

Table B 1. Illustration of a degree-of-freedom table for a BACI analysis assuming 4 seasons, 2 years per monitoring phase, and 2 impact/control pairs.

\begin{tabular}{lrl}
\hline Source & DF & F-test \\
\hline Total $_{\text {Cor }}$ & 31 & \\
Season & 3 & \\
Site pair & 1 & $F_{1,10}$ \\
Phase & 1 & \\
Site pair $\times$ phase & 1 & \\
Season $\times$ phase & 3 & \\
Season $\times$ pair & 3 & \\
Season $\times$ pair $\times$ phase & 9 & \\
Error & 10 & \\
\hline
\end{tabular}

The F-test for the main effect of the monitoring phase tests the overall effect of the mitigation action. However, the site-pair-by-phase interaction may likely occur because the fish response to the rechannelization at the potential impacted sites (i.e., $\mathrm{C}$ and $\mathrm{N}$ ) is anticipated to be different. Other interactions may also occur requiring more detailed interpretation of the data. Data plots and Tukey's test of additivity (Box et al. 1978:222-223) will be used to assure the impact assessment data are analyzed on the correct scale.

\section{Analysis of Acoustic-Tag Data}

Acoustic-tag arrays upstream and downstream of Sandy River Delta will be used to estimate average residence time in that reach. For fish known to have traversed the reach (i.e., detected both upstream and downstream), average residence time will be computed as the arithmetic average

$$
\bar{t}=\frac{\sum_{i=1}^{n} t_{i}}{n}
$$

where

$t_{i}=$ time between upstream and downstream detections,

$n$ = number of fish detected, 
with associated standard errors

$$
\mathrm{SE}(\bar{t})=\sqrt{\frac{\sum_{i=1}^{n}\left(t_{i}-\bar{t}\right)^{2}}{n(n-1)}} .
$$

Mean travel times will be computed for different fish stocks (i.e., yearling, subyearling Chinook salmon) and over different periods of the outmigration. If the rechannelization of the old channel is performed during this monitoring program, mean residence time will be compared between pre- and post-mitigation periods.

There will also be three single acoustic receivers located between the arrays to monitor fish activity. One of the receiver nodes is located at the old mouth of the Sandy River. This receiver node will be used to estimate an index of fish usage of the old channel environment. The index of usage will be calculated as the fraction.

$$
I=\frac{x}{m},(7)
$$

where

$\mathrm{m}=$ number of unique tagged fish detected at one or both of the acoustic arrays,

$x=$ number of the $m$ fish that are detected at the channel node.

Because the expected value of $x$ is a function of both the probability of old Sandy River mouth usage and detections, the value $I$ is only an index of proportional use. It will be important for the detection probability and location of the channel node to be constant over the course of the study in order to properly interpret trends in the value of $I$. The standard error for $I$ is based on the binomial sampling where

$$
\widehat{\mathrm{SE}}(I)=\sqrt{\frac{I(1-I)}{m}} .
$$

Again, in the case where rechannelization occurs during the course of the study, I can be compared between pre- and post-mitigation periods.

The three single arrays will also be used jointly to calculate an activity index within the vicinity of the Sandy River Delta. The linear contrast

$$
c_{i}=1 t_{3 i}-2 t_{2 i}+1 t_{1 i}
$$

where

$$
\begin{aligned}
& t_{1 i}=\text { arrival time of the } i \text { th fish to the first node }(i=1, \ldots, n) ; \\
& t_{2 i}=\text { arrival time of the } i \text { th fish to the middle node }(i=1, \ldots, n) ; \\
& t_{3 i}=\text { arrival time of the } i \text { th fish to the third (i.e., most downstream) node }(i=1, \ldots, n) ;
\end{aligned}
$$

will be approximately zero if the ith fish directly swims downstream through the array of three nodes. If, on the other hand, fish quickly travel past the two upstream nodes and then linger at or below the middle node before exiting the array, the contrast will increase in positive value. Hence, contrast (8) will provide an additional index of usage of the old channel mouth. Rechannelized activities might be 
expected to increase fish usage of the old channel, thereby increasing the activity index. For fish detected at the three nodes, the average activity index will be calculated as follows:

$$
\bar{c}=\frac{\sum_{i=1}^{m}\left(t_{3 i}-2 t_{2 i}+t_{1 i}\right)}{m}=\frac{\sum_{i=1}^{m} c_{i}}{m}
$$

with associated standard error

$$
\mathrm{SE}(\bar{c})=\sqrt{\frac{\sum_{i=1}^{m}\left(c_{i}-\bar{c}\right)^{2}}{m(m-1)}}
$$

where $m=$ number of fish detected at all three nodes.

\section{Literature Cited}

Box, G. E. P., W. G. Hunter, and J. S. Hunter. 1978. Statistics for experimenters. Wiley \& Sons, New York, New York, USA.

Skalski, J. R., and D. H. McKenzie. 1982. A design for aquatic monitoring programs. Journal of Environmental Management 14:237-251.

Zar, J. H. 1999. Biostatistical analysis. Fourth edition. Prentice-Hall, Inc., Upper Saddle River, New Jersey, USA. 


\section{Appendix C: Beach Seine Catch and Ancillary Data}

Table C 1. Ancillary Data for Beach Seines for the Tidal Freshwater Monitoring Study in 2007.

\begin{tabular}{|c|c|c|c|c|c|c|c|c|c|c|c|c|c|c|}
\hline Site & Date & Haul & Time & $\begin{array}{c}\text { Distance } \\
\text { Offshore } \\
\text { (m) }\end{array}$ & $\begin{array}{c}\text { Length } \\
\text { (m) }\end{array}$ & \begin{tabular}{|c} 
Depth \\
(m)
\end{tabular} & Boat/Foot & $\begin{array}{c}\text { Distance to } \\
\text { Benchmark } \\
(\mathbf{m})\end{array}$ & $\begin{array}{c}\text { Temp. } \\
\left({ }^{\circ} \mathrm{C}\right)\end{array}$ & $\begin{array}{c}\text { DO } \\
(\mathrm{mg} / \mathrm{L})\end{array}$ & $\begin{array}{c}\text { Salinity } \\
\text { (ppt) }\end{array}$ & $\begin{array}{l}\text { Flow } \\
(\mathrm{m} / \mathrm{s}) \\
\end{array}$ & $\begin{array}{c}\text { USGS Gage } \\
\text { Height (ft, at } \\
\text { I5 Bridge, } \\
\text { Vancouver) } \\
\end{array}$ & $\begin{array}{c}\text { Bonneville } \\
\text { Outflow } \\
\text { (kcfs) }\end{array}$ \\
\hline A & $8 / 15 / 2007$ & 1 & 1245 & - & - & - & Boat & 15.35 & 23.1 & 12.3 & 0.1 & - & 3.87 & 148 \\
\hline A & $8 / 15 / 2007$ & 2 & 1330 & - & - & - & Boat & - & 23.1 & 12.3 & 0.1 & - & 3.62 & 144.7 \\
\hline A & $9 / 12 / 2007$ & 1 & 1140 & 25 & 20 & 0.3 & Foot & - & 21.4 & 10.37 & 0.1 & 0.02 & 1.81 & 94.6 \\
\hline A & 9/12/2007 & 2 & 1220 & 20 & 20 & 0.6 & Foot & - & 21.4 & 10.37 & 0.1 & 0.02 & 1.63 & 94.8 \\
\hline A & $10 / 16 / 2007$ & 1 & 1430 & 15 & 25 & 0.6 & Foot & 29 & 15.1 & 9.81 & 0.1 & -0.02 & 1.65 & 90.2 \\
\hline A & $10 / 16 / 2007$ & 2 & 1500 & 20 & 49 & 1.0 & Foot & 29 & 15.1 & 9.81 & 0.1 & -0.02 & 1.55 & 89.9 \\
\hline A & $11 / 19 / 2007$ & 1 & 1445 & 15 & 22.8 & 0.91 & Boat & 20 & 9.5 & 10.94 & 0.1 & 0.05 & 4.43 & 121.6 \\
\hline $\mathrm{A}$ & $11 / 19 / 2007$ & 2 & 1500 & 10 & 22.8 & 0.91 & Boat & 20 & 9.5 & 10.94 & 0.1 & 0.05 & 4.39 & 121.6 \\
\hline A & $12 / 18 / 2007$ & 1 & 1110 & 10 & 15 & 1.2 & Foot & 21 & 6.1 & 11.9 & 0.1 & - & 4.9 & 131.4 \\
\hline A & $12 / 18 / 2007$ & 2 & 1140 & 15 & 15 & 1.2 & Foot & 21 & 6.1 & 11.9 & 0.1 & - & 5.17 & 131.7 \\
\hline $\mathrm{B}$ & 6/6/2007 & 1 & 950 & 10 & - & - & Boat & 5.9 & 15.8 & 9.09 & 0.1 & - & 5.98 & 250.6 \\
\hline $\mathrm{B}$ & $6 / 6 / 2007$ & 2 & 1025 & 10 & - & 3 & Boat & 5.9 & 15.8 & 9.09 & 0.1 & - & 6.03 & 249.6 \\
\hline $\mathrm{B}$ & $6 / 27 / 2007$ & 1 & 1115 & - & - & - & Boat & 15.8 & 17.3 & 9.17 & 0.1 & - & 3.05 & 162.2 \\
\hline $\mathrm{B}$ & $6 / 27 / 2007$ & 2 & 1135 & - & - & - & Boat & 15.8 & 17.3 & 9.17 & 0.1 & - & 2.73 & 162.2 \\
\hline $\mathrm{B}$ & $7 / 11 / 2007$ & 1 & 1130 & - & - & - & Boat & 16.4 & 20.6 & 7.3 & 0.1 & - & 3.18 & 149 \\
\hline $\mathrm{B}$ & $7 / 11 / 2007$ & 2 & 1145 & - & - & - & Boat & 16.4 & 20.8 & 8.5 & 0.1 & - & 3.11 & 149 \\
\hline B & $8 / 14 / 2007$ & 1 & 1222 & - & - & - & Foot & 17.4 & 22.9 & 12.05 & 0.1 & - & 3.27 & 150.8 \\
\hline $\mathrm{B}$ & $8 / 14 / 2007$ & 2 & 1245 & - & - & - & Foot & - & 22.9 & 12.05 & 0.1 & - & 3.11 & 150.8 \\
\hline $\mathrm{B}$ & $9 / 11 / 2007$ & 1 & 1255 & 6 & 20 & 2 & Foot & - & 22 & 11.2 & 0.1 & 0.01 & 0.72 & 88.7 \\
\hline B & $9 / 11 / 2007$ & 2 & 1325 & 8 & 20 & 2 & Foot & - & 22 & 11.2 & 0.1 & 0.01 & 0.54 & 102.1 \\
\hline $\mathrm{B}$ & $10 / 17 / 2007$ & 1 & 1123 & 4.6 & 25 & 1.2 & Foot & 23.8 & 13.1 & 9.9 & 0.1 & 0.01 & 2.63 & 90 \\
\hline \multicolumn{15}{|c|}{ - Data not measured } \\
\hline $\mathrm{B}$ & $10 / 17 / 2007$ & 2 & 1151 & 4.6 & 25 & 1.2 & Foot & 23.8 & 13.1 & 9.9 & 0.1 & 0.01 & 2.47 & 90 \\
\hline
\end{tabular}




\begin{tabular}{|c|c|c|c|c|c|c|c|c|c|c|c|c|c|c|}
\hline Site & Date & Haul & Time & $\begin{array}{c}\text { Distance } \\
\text { Offshore } \\
\text { (m) }\end{array}$ & $\begin{array}{c}\text { Length } \\
\text { (m) }\end{array}$ & $\begin{array}{c}\text { Depth } \\
\text { (m) }\end{array}$ & Boat/Foot & $\begin{array}{c}\text { Distance to } \\
\text { Benchmark } \\
\text { (m) }\end{array}$ & $\begin{array}{c}\text { Temp. } \\
\left({ }^{\circ} \mathrm{C}\right)\end{array}$ & $\begin{array}{c}\text { DO } \\
(\mathrm{mg} / \mathrm{L})\end{array}$ & $\begin{array}{c}\text { Salinity } \\
\text { (ppt) }\end{array}$ & $\begin{array}{l}\text { Flow } \\
(\mathrm{m} / \mathrm{s})\end{array}$ & $\begin{array}{l}\text { USGS Gage } \\
\text { Height (ft, at } \\
\text { I5 Bridge, } \\
\text { Vancouver) }\end{array}$ & $\begin{array}{c}\text { Bonneville } \\
\text { Outflow } \\
\text { (kcfs) }\end{array}$ \\
\hline $\mathrm{B}$ & $11 / 19 / 2007$ & 1 & 950 & 2.5 & 13.7 & 1.5 & Foot & 27.3 & 8.8 & 9.15 & 0.1 & 0.02 & 3.04 & 121.1 \\
\hline B & $11 / 19 / 2007$ & 2 & 1010 & 2.5 & 20 & 1.5 & Foot & 27.3 & 8.8 & 9.15 & 0.1 & 0.02 & 3.25 & 121.1 \\
\hline $\mathrm{B}$ & $12 / 18 / 2007$ & 1 & 1425 & 4 & 21 & 1.4 & Foot & 17.5 & 6.1 & 10.68 & 0.1 & - & 4.6 & 124.1 \\
\hline $\mathrm{B}$ & $12 / 18 / 2007$ & 2 & 1445 & 4 & 21 & 1.4 & Foot & 17.5 & 6.1 & 10.68 & 0.1 & - & 4.52 & 119.2 \\
\hline $\mathrm{C}$ & 6/6/2007 & 1 & 1050 & 15 & - & 0.9 & Boat & 11.05 & 16.3 & 9.38 & 0.1 & - & 6.02 & 249.6 \\
\hline $\mathrm{C}$ & 6/6/2007 & 2 & 1130 & 20 & - & 0.8 & Boat & 11.05 & 16.3 & 9.38 & 0.1 & - & 5.95 & 250 \\
\hline $\mathrm{C}$ & $6 / 27 / 2007$ & 1 & 1305 & - & - & - & Boat & 31.9 & 19.4 & 9.4 & 0.1 & - & 2.63 & 175.1 \\
\hline $\mathrm{C}$ & $6 / 27 / 2007$ & 2 & 1325 & - & - & - & Boat & 31.9 & 19.4 & 9.4 & 0.1 & - & 2.56 & 175.1 \\
\hline $\mathrm{C}$ & $7 / 11 / 2007$ & 1 & 1245 & - & - & - & Foot & - & 22.7 & 8.9 & 0.1 & - & 2.86 & 150.2 \\
\hline $\mathrm{C}$ & $7 / 11 / 2007$ & 2 & 1305 & - & - & - & Foot & - & 22.9 & 9.32 & 0.1 & - & 2.83 & 167.7 \\
\hline $\mathrm{C}$ & $8 / 14 / 2007$ & 1 & 1400 & - & - & - & Foot & 59.5 & 24.5 & 12.7 & 0.1 & - & 2.69 & 158.9 \\
\hline $\mathrm{C}$ & $8 / 14 / 2007$ & 2 & 1428 & - & - & - & Foot & - & 24.5 & 12.7 & 0.1 & - & 2.55 & 158.9 \\
\hline $\mathrm{C}$ & $9 / 12 / 2007$ & 1 & 1020 & 15 & 15 & 0.1 & Foot & - & 18.3 & 9.2 & 0.1 & 0 & 2.4 & 95 \\
\hline $\mathrm{C}$ & 9/12/2007 & 2 & 1050 & 20 & 20 & 0.1 & Foot & - & 18.3 & 9.2 & 0.1 & 0 & 2.2 & 95 \\
\hline $\mathrm{C}$ & $11 / 19 / 2007$ & 1 & 1215 & 20 & 14.6 & 0.91 & Foot & 62.2 & 7.6 & 10.72 & 0.1 & 0.01 & 4.21 & 123.1 \\
\hline $\mathrm{C}$ & $11 / 19 / 2007$ & 2 & 1335 & 20 & 21.3 & 0.46 & Foot & 62.2 & 7.6 & 10.72 & 0.1 & 0.01 & 4.14 & 123.2 \\
\hline $\mathrm{C}$ & $12 / 19 / 2007$ & 1 & 1050 & 15 & 15 & 0.46 & Foot & 60 & 6.9 & 11.06 & 0.1 & - & 4.47 & 122.6 \\
\hline $\mathrm{C}$ & 12/19/2007 & 2 & 1245 & 15 & 15 & 0.61 & Foot & 60 & 6.9 & 11.06 & 0.1 & - & 6.07 & 123.6 \\
\hline $\mathrm{D}$ & 6/6/2007 & 1 & 1240 & 25 & - & 2 & Boat & 7.6 & 17 & 9.56 & 0.1 & - & 5.77 & 249.7 \\
\hline $\mathrm{D}$ & 6/6/2007 & 2 & 1320 & 25 & - & 2 & Boat & 7.6 & 17 & 9.56 & 0.1 & - & 5.7 & 249.6 \\
\hline $\mathrm{D}$ & $6 / 26 / 2007$ & 1 & 1148 & 20 & - & 0.9 & Foot & 15.8 & 20.7 & 8.4 & 0.1 & - & 2.24 & 201.7 \\
\hline $\mathrm{D}$ & $6 / 26 / 2007$ & 2 & 1210 & 20 & - & 0.8 & Foot & 15.8 & 20.7 & 8.4 & 0.1 & - & 2.16 & 208.2 \\
\hline $\mathrm{D}$ & $7 / 11 / 2007$ & 1 & 1435 & - & - & - & Foot & - & 24.7 & 9.93 & 0.1 & - & 3.01 & 170.7 \\
\hline $\mathrm{D}$ & $7 / 11 / 2007$ & 2 & 1450 & - & - & - & Foot & - & 24.7 & 9.77 & 0.1 & - & 3.1 & 170.7 \\
\hline $\mathrm{D}$ & $8 / 15 / 2007$ & 1 & 1415 & - & - & - & Foot & 17.4 & 25.7 & 10.7 & 0.1 & - & 3.36 & 145.8 \\
\hline $\mathrm{D}$ & $8 / 15 / 2007$ & 2 & 1435 & - & - & - & Foot & - & 25.7 & 10.7 & 0.1 & - & 3.28 & 145.8 \\
\hline $\mathrm{D}$ & $9 / 11 / 2007$ & 1 & 957 & 15 & 20 & 0.3 & Foot & - & 17.6 & 8.12 & 0.1 & - & 1.88 & 85.8 \\
\hline
\end{tabular}




\begin{tabular}{|c|c|c|c|c|c|c|c|c|c|c|c|c|c|c|}
\hline Site & Date & Haul & Time & $\begin{array}{c}\text { Distance } \\
\text { Offshore } \\
(\mathbf{m}) \\
\end{array}$ & $\begin{array}{c}\text { Length } \\
\text { (m) }\end{array}$ & $\begin{array}{c}\text { Depth } \\
\text { (m) } \\
\end{array}$ & Boat/Foot & $\begin{array}{c}\text { Distance to } \\
\text { Benchmark } \\
\text { (m) }\end{array}$ & $\begin{array}{c}\text { Temp. } \\
\left({ }^{\circ} \mathrm{C}\right) \\
\end{array}$ & $\begin{array}{c}\text { DO } \\
(\mathrm{mg} / \mathrm{L}) \\
\end{array}$ & $\begin{array}{c}\text { Salinity } \\
\text { (ppt) }\end{array}$ & $\begin{array}{l}\text { Flow } \\
(\mathrm{m} / \mathrm{s}) \\
\end{array}$ & $\begin{array}{c}\text { USGS Gage } \\
\text { Height (ft, at } \\
\text { I5 Bridge, } \\
\text { Vancouver) } \\
\end{array}$ & $\begin{array}{c}\text { Bonneville } \\
\text { Outflow } \\
\text { (kcfs) }\end{array}$ \\
\hline $\mathrm{D}$ & $9 / 11 / 2007$ & 2 & 1020 & 15 & 20 & 0.3 & Foot & - & 17.6 & 8.12 & 0.1 & - & 1.77 & 86.4 \\
\hline $\mathrm{D}$ & $10 / 17 / 2007$ & 1 & 1406 & 7.6 & 23 & 0.2 & Foot & 45 & 13.3 & 11.22 & 0.1 & 0.01 & 1.8 & 90.2 \\
\hline $\mathrm{D}$ & $10 / 17 / 2007$ & 2 & 1419 & 15 & 25 & 0.2 & Foot & 45 & 13.3 & 11.22 & 0.1 & 1.01 & 1.72 & 90.2 \\
\hline $\mathrm{D}$ & $11 / 20 / 2007$ & 1 & 945 & 12.2 & 22.8 & 0.5 & Foot & 31.8 & 8.2 & 11.41 & 0.1 & 0 & 2.89 & 119.7 \\
\hline $\mathrm{D}$ & 11/20/2007 & 2 & 1010 & 12.1 & 17 & 1 & Foot & 32.8 & 8.2 & 11.41 & 0.1 & 0 & 3.01 & 119.7 \\
\hline $\mathrm{D}$ & $12 / 19 / 2007$ & 1 & 915 & 20 & 16.5 & 0.30 & Foot & 29 & 6.6 & 9.96 & 0.1 & - & 2.97 & 122.8 \\
\hline $\mathrm{D}$ & $12 / 19 / 2007$ & 2 & 950 & 20 & 16.5 & 0.30 & Foot & 29 & 6.6 & 9.96 & 0.1 & - & 3.38 & 122.4 \\
\hline $\mathrm{E}$ & 9/11/2007 & 1 & 1133 & 10 & 20 & 3.4 & Boat & - & 22.4 & 10.2 & 0.1 & 0.01 & 1.28 & 86.5 \\
\hline $\mathrm{E}$ & $9 / 11 / 2007$ & 2 & 1210 & 20 & 20 & 4.3 & Boat & - & 22.4 & 10.2 & 0.1 & 0.01 & 1.01 & 88.7 \\
\hline $\mathrm{E}$ & $10 / 16 / 2007$ & 1 & 1256 & 4.6 & 21 & 1.7 & Foot & 31.4 & 14.5 & 12.42 & 0.1 & 0.01 & 1.8 & 112.3 \\
\hline $\mathrm{E}$ & $10 / 16 / 2007$ & 2 & 1341 & 4.6 & 21 & 1.7 & Foot & 31.4 & 14.5 & 12.42 & 0.1 & 0.01 & 1.62 & 112.2 \\
\hline $\mathrm{E}$ & $11 / 19 / 2007$ & 1 & 1110 & 30 & 17.2 & 2.6 & Boat & 22.7 & 9.7 & 9.54 & 0.1 & 0.01 & 3.96 & 122.7 \\
\hline $\mathrm{E}$ & 11/19/2007 & 2 & 1130 & 20 & 17.5 & 2.7 & Boat & 22.7 & 9.7 & 9.54 & 0.1 & 0.01 & 4.07 & 122.7 \\
\hline $\mathrm{E}$ & $12 / 18 / 2007$ & 1 & 1245 & 9 & 7 & 1.0 & Boat & 18.6 & 6.3 & 11.98 & 0.1 & - & 5.2 & 129 \\
\hline $\mathrm{E}$ & $12 / 18 / 2007$ & 2 & 1305 & 4.6 & 7.6 & 1.0 & Boat & 18.6 & 6.3 & 11.98 & 0.1 & - & 5.12 & 129 \\
\hline $\mathrm{N}$ & 6/6/2007 & 1 & 1605 & 15 & - & 0.9 & Foot & - & 21.2 & 6.41 & 0.1 & - & 5.29 & 259.9 \\
\hline $\mathrm{N}$ & $6 / 26 / 2007$ & 1 & 940 & 15 & - & 1 & Foot & - & 19.7 & 7.11 & 0.1 & - & 2.67 & 175.6 \\
\hline $\mathrm{N}$ & $6 / 26 / 2007$ & 2 & 1000 & 15 & - & 1 & Foot & - & 19.7 & 7.11 & 0.1 & - & 2.6 & 189.2 \\
\hline $\mathrm{N}$ & $7 / 19 / 2007$ & 1 & 820 & - & - & - & Foot & - & 22 & 3.6 & 0.1 & - & 4.24 & 166.1 \\
\hline $\mathrm{N}$ & $7 / 19 / 2007$ & 2 & 925 & - & - & - & Foot & - & 22 & 3.6 & 0.1 & - & 4.64 & 165.3 \\
\hline $\mathrm{N}$ & $8 / 14 / 2007$ & 1 & 920 & - & - & - & Foot & 50 & 20.3 & 8.08 & 0.1 & - & 4.41 & 131.9 \\
\hline $\mathrm{N}$ & $8 / 14 / 2007$ & 2 & 1004 & - & - & - & Foot & - & 20.3 & 8.08 & 0.1 & - & 4.05 & 147.5 \\
\hline $\mathrm{N}$ & $9 / 12 / 2007$ & 1 & 1400 & 10 & 15 & 0.6 & Foot & - & 18.2 & 3.24 & 0.1 & 0 & 0.98 & 102.2 \\
\hline $\mathrm{N}$ & $9 / 12 / 2007$ & 2 & 1500 & 8 & 15 & 0.6 & Foot & - & 18.2 & 3.24 & 0.1 & 0 & 0.76 & 102.2 \\
\hline $\mathrm{N}$ & $10 / 16 / 2007$ & 1 & 945 & 10 & 15 & 1 & Foot & - & 12.3 & 1.85 & 0.1 & - & 2.63 & 110.5 \\
\hline $\mathrm{N}$ & $10 / 16 / 2007$ & 2 & 1030 & 10 & 15 & 0.5 & Foot & - & 12.3 & 1.85 & 0.1 & - & 2.63 & 111.3 \\
\hline $\mathrm{N}$ & $11 / 20 / 2007$ & 1 & 1330 & 10.6 & 25.9 & 1.2 & Foot & - & 10.1 & 3.62 & 0.1 & - & 4.67 & 123.1 \\
\hline
\end{tabular}




\begin{tabular}{|c|c|c|c|c|c|c|c|c|c|c|c|c|c|c|}
\hline Site & Date & Haul & Time & $\begin{array}{c}\text { Distance } \\
\text { Offshore } \\
(\mathrm{m})\end{array}$ & $\begin{array}{c}\text { Length } \\
\text { (m) }\end{array}$ & $\begin{array}{c}\text { Depth } \\
\text { (m) }\end{array}$ & Boat/Foot & $\begin{array}{c}\text { Distance to } \\
\text { Benchmark } \\
\text { (m) }\end{array}$ & $\begin{array}{c}\text { Temp. } \\
\left({ }^{\circ} \mathrm{C}\right)\end{array}$ & $\begin{array}{c}\text { DO } \\
(\mathrm{mg} / \mathrm{L})\end{array}$ & $\begin{array}{c}\text { Salinity } \\
\text { (ppt) }\end{array}$ & $\begin{array}{l}\text { Flow } \\
(\mathrm{m} / \mathrm{s})\end{array}$ & $\begin{array}{l}\text { USGS Gage } \\
\text { Height (ft, at } \\
\text { I5 Bridge, } \\
\text { Vancouver) }\end{array}$ & $\begin{array}{c}\text { Bonneville } \\
\text { Outflow } \\
\text { (kcfs) }\end{array}$ \\
\hline $\mathrm{N}$ & $11 / 20 / 2007$ & 2 & 1430 & 9.1 & 24.3 & 1.2 & Foot & - & 10.1 & 3.62 & 0.1 & - & 4.68 & 123.9 \\
\hline $\mathrm{N}$ & $12 / 18 / 2007$ & 1 & 920 & 9 & 15 & 0.61 & Foot & - & 5.6 & 7.98 & 0.1 & - & 3.17 & 130.3 \\
\hline $\mathrm{N}$ & $12 / 18 / 2007$ & 2 & 945 & 4.6 & 4.6 & 0.61 & Foot & - & 5.6 & 7.98 & 0.1 & - & 3.66 & 131 \\
\hline
\end{tabular}

Table C 2. Beach Seine Data for the Tidal Freshwater Monitoring Study in 2007.

\begin{tabular}{|c|c|c|c|c|c|c|c|c|c|c|c|c|c|c|c|}
\hline Site & Date & Haul & $\begin{array}{c}\text { Chinook } \\
\qquad(0+)\end{array}$ & $\begin{array}{c}\text { Chinook } \\
(1+)\end{array}$ & Coho & $\begin{array}{l}\text { American } \\
\text { Shad }\end{array}$ & $\begin{array}{l}\text { Amur } \\
\text { Goby }\end{array}$ & Bluegill & $\begin{array}{l}\text { Brown } \\
\text { Bullhead }\end{array}$ & Chiselmouth & Carp & Crappie & Dace & Killifish & $\begin{array}{c}\text { Largemouth } \\
\text { Bass }\end{array}$ \\
\hline A & $8 / 15 / 2007$ & 1 & 1 & - & - & - & - & - & - & - & - & - & - & 3 & 1 \\
\hline A & $8 / 15 / 2007$ & 2 & - & - & - & - & - & - & - & - & - & - & - & 4 & - \\
\hline A & 9/12/2007 & 1 & - & - & - & - & - & - & - & - & - & - & - & 1 & - \\
\hline A & 9/12/2007 & 2 & - & - & - & - & - & - & - & - & - & - & - & 1 & - \\
\hline A & $10 / 16 / 2007$ & 1 & - & - & - & - & - & - & - & - & - & - & - & 14 & - \\
\hline A & $10 / 16 / 2007$ & 2 & - & - & - & 6 & - & - & - & - & - & - & - & - & - \\
\hline A & 11/19/2007 & 1 & - & - & - & 1 & - & - & - & - & - & - & - & 3 & - \\
\hline A & 11/19/2007 & 2 & - & - & - & - & - & - & - & - & - & - & - & 1 & - \\
\hline A & $12 / 18 / 2007$ & 1 & 2 & - & - & - & - & - & - & - & - & - & - & 3 & - \\
\hline $\mathrm{B}$ & $6 / 6 / 2007$ & 1 & 1 & - & - & - & - & - & - & - & - & - & - & - & - \\
\hline B & 6/6/2007 & 2 & - & - & - & - & - & - & - & - & - & - & - & - & - \\
\hline $\mathrm{B}$ & $6 / 27 / 2007$ & 1 & 9 & - & - & - & - & - & - & - & - & - & - & - & - \\
\hline \multicolumn{16}{|c|}{ - Denotes fish were not collected during the sample period } \\
\hline B & 6/27/2007 & 2 & 7 & - & - & - & - & - & - & - & - & - & - & - & - \\
\hline
\end{tabular}




\begin{tabular}{|c|c|c|c|c|c|c|c|c|c|c|c|c|c|c|c|}
\hline Site & Date & Haul & $\begin{array}{c}\text { Chinook } \\
\left(0^{+}\right)\end{array}$ & $\begin{array}{c}\text { Chinook } \\
(1+)\end{array}$ & Coho & $\begin{array}{l}\text { American } \\
\text { Shad }\end{array}$ & $\begin{array}{l}\text { Amur } \\
\text { Goby }\end{array}$ & Bluegill & $\begin{array}{l}\text { Brown } \\
\text { Bullhead }\end{array}$ & Chiselmouth & Carp & Crappie & Dace & Killifish & $\begin{array}{c}\text { Largemouth } \\
\text { Bass }\end{array}$ \\
\hline B & 7/11/2007 & 1 & 1 & - & - & - & - & - & - & - & - & - & - & - & - \\
\hline B & 7/11/2007 & 2 & 1 & - & - & - & - & - & - & - & - & - & - & 2 & 1 \\
\hline B & 8/14/2007 & 1 & - & - & - & - & - & - & - & - & - & - & - & 1 & 1 \\
\hline B & $8 / 14 / 2007$ & 2 & - & - & - & 10 & - & - & - & - & - & - & - & 2 & - \\
\hline B & 9/11/2007 & 1 & - & - & - & 2 & - & 11 & - & - & - & - & - & - & - \\
\hline B & 9/11/2007 & 2 & - & - & - & - & - & 9 & 2 & - & 1 & - & - & 17 & 1 \\
\hline B & $10 / 17 / 2007$ & 1 & - & - & - & - & - & 16 & - & - & & - & - & 1 & - \\
\hline B & $10 / 17 / 2007$ & 2 & - & - & - & - & - & 29 & - & - & & - & - & - & - \\
\hline B & $11 / 19 / 2007$ & 1 & - & - & - & - & - & - & - & - & - & - & - & - & - \\
\hline $\mathrm{B}$ & $12 / 18 / 2007$ & 1 & 1 & - & - & - & - & 1 & - & - & - & - & - & - & - \\
\hline B & $12 / 18 / 2007$ & 2 & - & - & - & - & - & 8 & - & - & - & - & - & - & - \\
\hline $\mathrm{C}$ & 6/6/2007 & 1 & 9 & - & - & - & - & - & - & - & - & - & - & - & - \\
\hline $\mathrm{C}$ & $6 / 6 / 2007$ & 2 & 21 & - & - & - & - & - & - & - & - & - & - & 17 & - \\
\hline $\mathrm{C}$ & $6 / 27 / 2007$ & 1 & - & - & - & - & - & - & - & - & - & - & - & - & - \\
\hline $\mathrm{C}$ & $6 / 27 / 2007$ & 2 & - & - & - & - & - & - & - & - & - & - & - & 15 & 2 \\
\hline $\mathrm{C}$ & 7/11/2007 & 1 & - & - & - & - & - & - & - & - & 1 & - & - & 3 & 3 \\
\hline $\mathrm{C}$ & 7/11/2007 & 2 & - & - & - & - & - & - & - & - & - & - & - & 2 & - \\
\hline $\mathrm{C}$ & $8 / 14 / 2007$ & 1 & - & - & - & - & - & - & - & - & - & - & - & 55 & 3 \\
\hline $\mathrm{C}$ & $8 / 14 / 2007$ & 2 & - & - & - & - & - & - & - & - & - & - & - & 7 & - \\
\hline $\mathrm{C}$ & 9/12/2007 & 1 & - & - & - & - & - & - & - & - & - & - & - & 17 & - \\
\hline $\mathrm{C}$ & $11 / 19 / 2007$ & 2 & - & - & - & - & - & - & 1 & - & - & - & 1 & 28 & 1 \\
\hline
\end{tabular}




\begin{tabular}{|c|c|c|c|c|c|c|c|c|c|c|c|c|c|c|c|}
\hline Site & Date & Haul & $\begin{array}{c}\text { Chinook } \\
\left(0^{+}\right)\end{array}$ & $\begin{array}{c}\text { Chinook } \\
(1+)\end{array}$ & Coho & $\begin{array}{l}\text { American } \\
\text { Shad }\end{array}$ & $\begin{array}{l}\text { Amur } \\
\text { Goby }\end{array}$ & Bluegill & $\begin{array}{c}\text { Brown } \\
\text { Bullhead }\end{array}$ & Chiselmouth & Carp & Crappie & Dace & Killifish & $\begin{array}{c}\text { Largemouth } \\
\text { Bass }\end{array}$ \\
\hline $\mathrm{C}$ & $12 / 19 / 2007$ & 1 & 5 & - & 10 & - & - & 2 & - & - & - & - & 2 & 2019 & - \\
\hline $\mathrm{C}$ & $12 / 19 / 2007$ & 2 & - & - & 1 & - & - & - & - & - & - & - & - & 11 & - \\
\hline $\mathrm{D}$ & 6/6/2007 & 1 & 38 & 1 & - & 6 & - & - & - & - & - & - & - & - & - \\
\hline $\mathrm{D}$ & 6/6/2007 & 2 & 91 & - & - & 4 & - & - & - & 1 & - & - & - & - & - \\
\hline $\mathrm{D}$ & 6/26/2007 & 1 & 22 & - & - & - & - & - & - & - & - & - & - & 1 & - \\
\hline $\mathrm{D}$ & 6/26/2007 & 2 & 33 & - & - & - & - & - & - & - & - & - & - & - & - \\
\hline $\mathrm{D}$ & 7/11/2007 & 1 & - & - & - & - & - & 2 & - & - & - & - & - & 9 & 1 \\
\hline $\mathrm{D}$ & 7/11/2007 & 2 & - & - & - & - & - & - & - & - & - & - & - & 6 & - \\
\hline $\mathrm{D}$ & 8/15/2007 & 1 & - & - & - & - & - & - & - & - & - & - & - & - & - \\
\hline $\mathrm{D}$ & 9/11/2007 & 1 & - & - & - & - & - & - & - & - & - & - & - & 4 & - \\
\hline $\mathrm{D}$ & 9/11/2007 & 2 & - & - & - & - & - & - & - & - & - & - & - & 1 & - \\
\hline $\mathrm{D}$ & $10 / 17 / 2007$ & 1 & - & - & - & - & - & - & - & - & - & - & - & 164 & - \\
\hline $\mathrm{D}$ & 10/17/2007 & 2 & - & - & - & - & - & - & - & - & - & - & - & 202 & - \\
\hline $\mathrm{D}$ & $11 / 20 / 2007$ & 1 & - & - & - & - & - & - & - & - & - & - & - & - & - \\
\hline $\mathrm{D}$ & $11 / 20 / 2007$ & 2 & - & - & - & - & - & - & - & - & - & - & - & 1 & - \\
\hline $\mathrm{D}$ & $12 / 19 / 2007$ & 1 & - & - & - & - & - & - & - & - & - & - & - & 11 & - \\
\hline $\mathrm{D}$ & $12 / 19 / 2007$ & 2 & - & - & - & - & - & - & - & - & - & - & - & - & - \\
\hline $\mathrm{E}$ & 9/11/2007 & 1 & - & - & - & 18 & - & 1 & - & - & - & - & - & 2 & - \\
\hline $\mathrm{E}$ & 9/11/2007 & 2 & - & - & - & - & - & 2 & - & - & - & - & - & 5 & - \\
\hline $\mathrm{E}$ & $10 / 16 / 2007$ & 1 & - & - & - & - & - & - & - & - & - & - & - & 13 & - \\
\hline $\mathrm{E}$ & $11 / 19 / 2007$ & 2 & 3 & - & - & 1 & - & - & - & - & - & - & 1 & 2 & - \\
\hline
\end{tabular}




\begin{tabular}{|c|c|c|c|c|c|c|c|c|c|c|c|c|c|c|c|}
\hline Site & Date & Haul & $\begin{array}{c}\text { Chinook } \\
\left(0^{+}\right)\end{array}$ & $\begin{array}{c}\text { Chinook } \\
(1+)\end{array}$ & Coho & $\begin{array}{l}\text { American } \\
\text { Shad }\end{array}$ & $\begin{array}{l}\text { Amur } \\
\text { Goby }\end{array}$ & Bluegill & $\begin{array}{l}\text { Brown } \\
\text { Bullhead }\end{array}$ & Chiselmouth & Carp & Crappie & Dace & Killifish & $\begin{array}{c}\text { Largemouth } \\
\text { Bass }\end{array}$ \\
\hline $\mathrm{E}$ & $12 / 18 / 2007$ & 1 & - & - & - & - & - & 2 & - & - & - & - & - & 3 & - \\
\hline $\mathrm{E}$ & $12 / 18 / 2007$ & 2 & 56 & - & 6 & - & - & - & - & - & - & - & - & 1 & 1 \\
\hline $\mathrm{N}$ & 6/6/2007 & 1 & 2 & - & 2 & - & - & 22 & - & 4 & - & - & 2 & 8 & 2 \\
\hline $\mathrm{N}$ & 6/26/2007 & 1 & - & - & - & - & & 2 & - & - & - & - & - & - & 18 \\
\hline $\mathrm{N}$ & $6 / 26 / 2007$ & 2 & - & - & - & - & 1 & 1 & - & - & - & - & - & 1 & 25 \\
\hline $\mathrm{N}$ & 7/19/2007 & 1 & - & - & - & - & - & 47 & - & - & 5 & 5 & - & 4 & 52 \\
\hline $\mathrm{N}$ & 7/19/2007 & 2 & - & - & - & - & - & 9 & - & - & 1 & 1 & - & 9 & 19 \\
\hline $\mathrm{N}$ & $8 / 14 / 2007$ & 1 & - & - & - & - & - & 70 & - & - & 2 & 28 & - & 18 & 58 \\
\hline $\mathrm{N}$ & $8 / 14 / 2007$ & 2 & - & - & - & - & - & 22 & - & - & & 3 & - & 2 & 17 \\
\hline $\mathrm{N}$ & 9/12/2007 & 2 & - & - & - & - & - & 12 & - & - & - & 4 & - & 2 & 23 \\
\hline $\mathrm{N}$ & $10 / 16 / 2007$ & 1 & - & - & - & - & 2 & 130 & - & - & - & 1 & - & 50 & 22 \\
\hline $\mathrm{N}$ & $10 / 16 / 2007$ & 2 & - & - & - & - & - & 5 & - & - & - & - & - & 3 & 1 \\
\hline $\mathrm{N}$ & $11 / 20 / 2007$ & 1 & - & - & - & - & - & 27 & 3 & - & - & - & - & 3 & - \\
\hline $\mathrm{N}$ & $11 / 20 / 2007$ & 2 & - & - & - & - & - & 107 & 1 & - & - & - & - & 12 & 2 \\
\hline $\mathrm{N}$ & $12 / 18 / 2007$ & 1 & - & - & - & - & - & 1 & - & - & - & - & - & - & - \\
\hline $\mathrm{N}$ & $12 / 18 / 2007$ & 2 & - & - & - & - & - & - & - & - & - & - & - & 1 & - \\
\hline
\end{tabular}




\section{Appendix D: Photos}

Site A
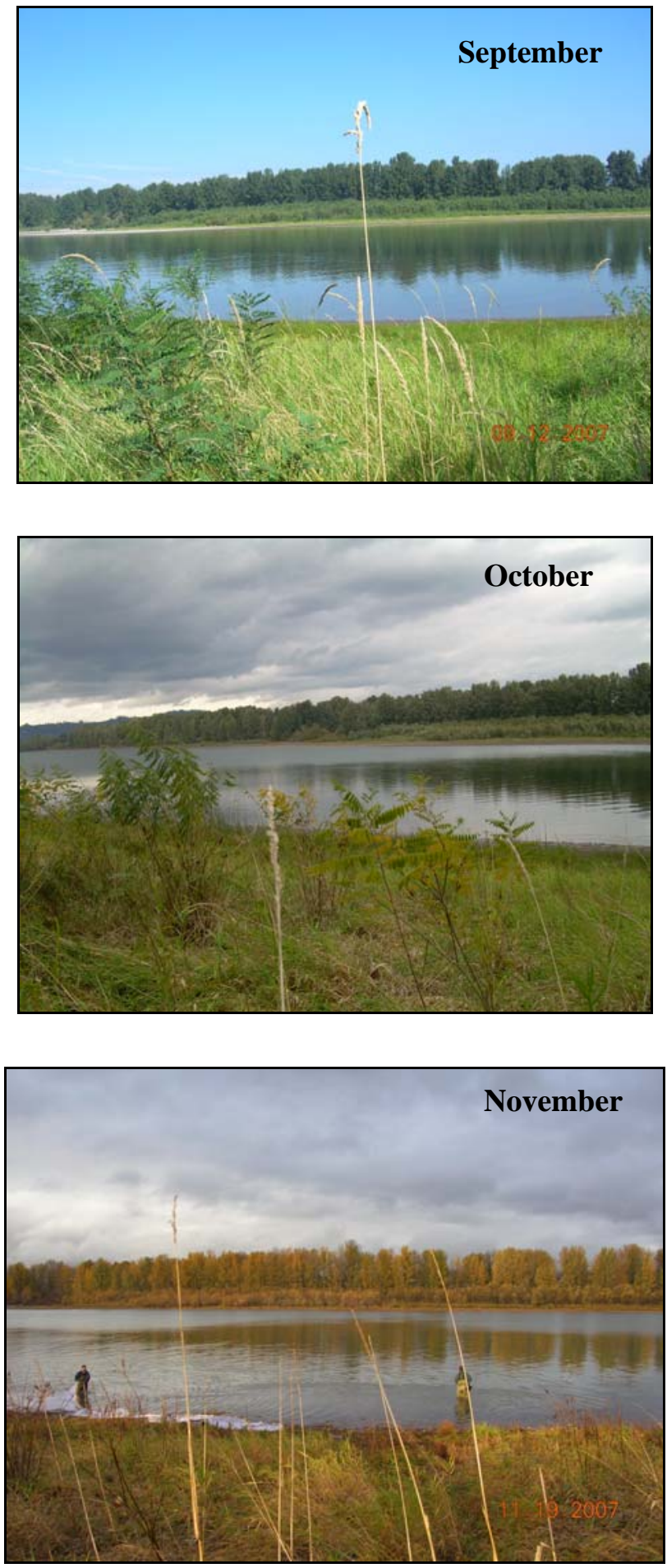

D.1 


\section{Site B}
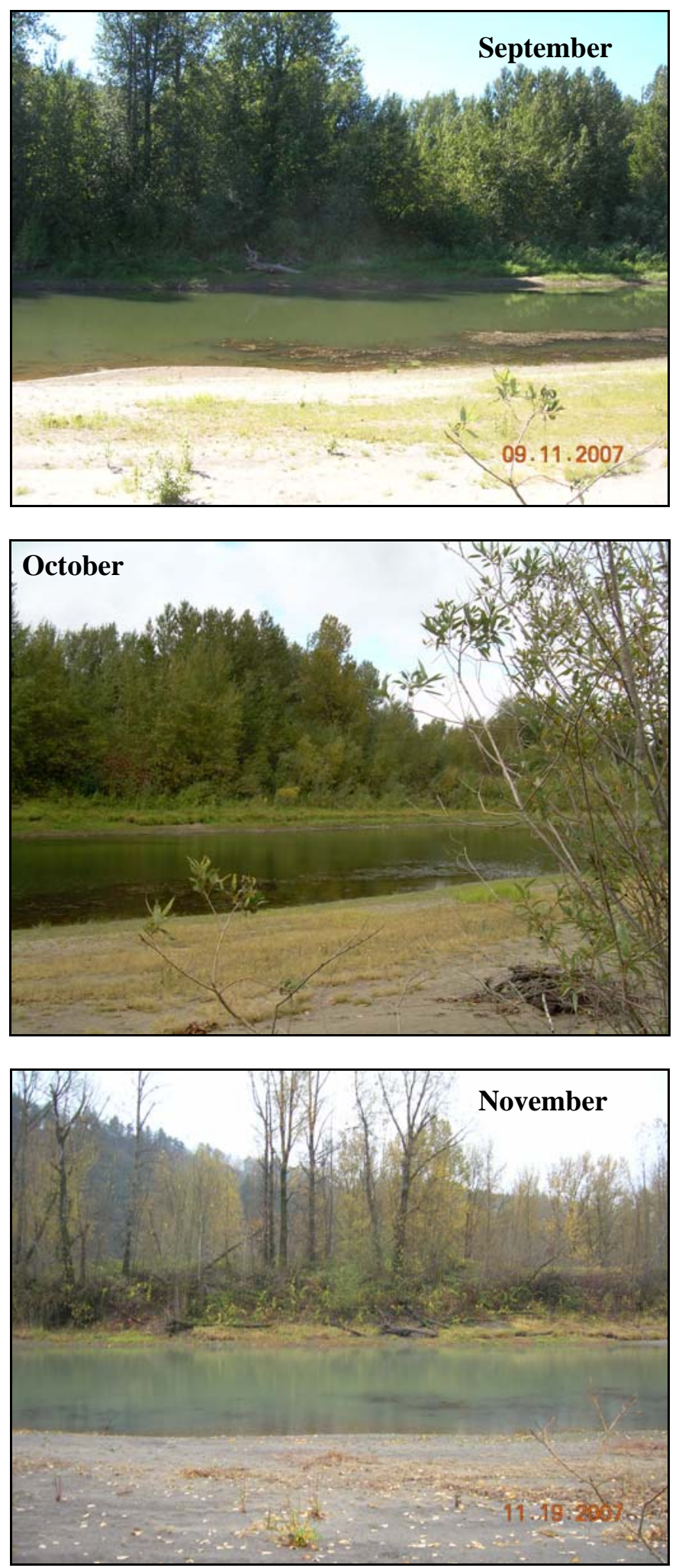

D. 2 


\section{Site C}
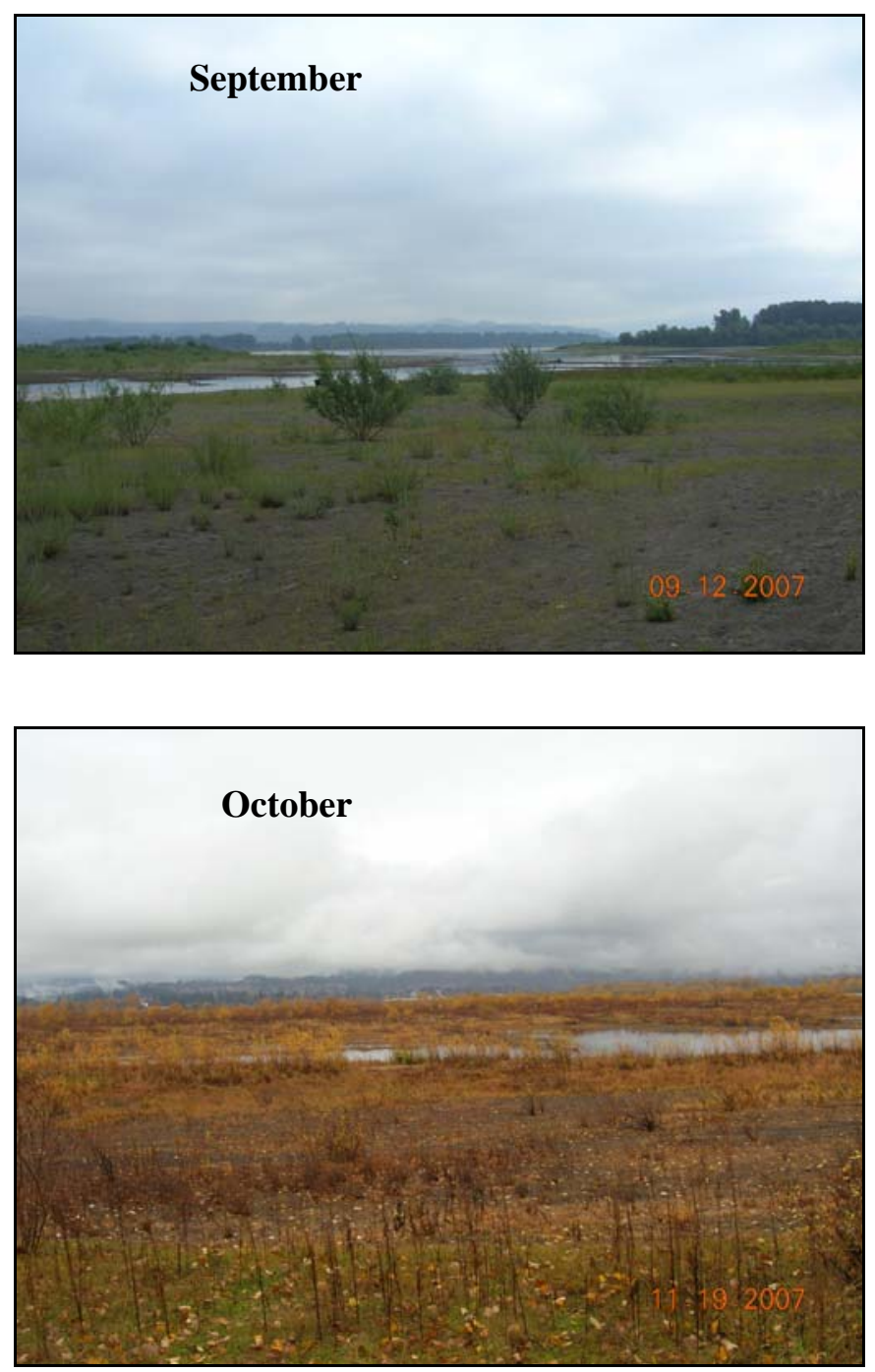

D.3 
Site D
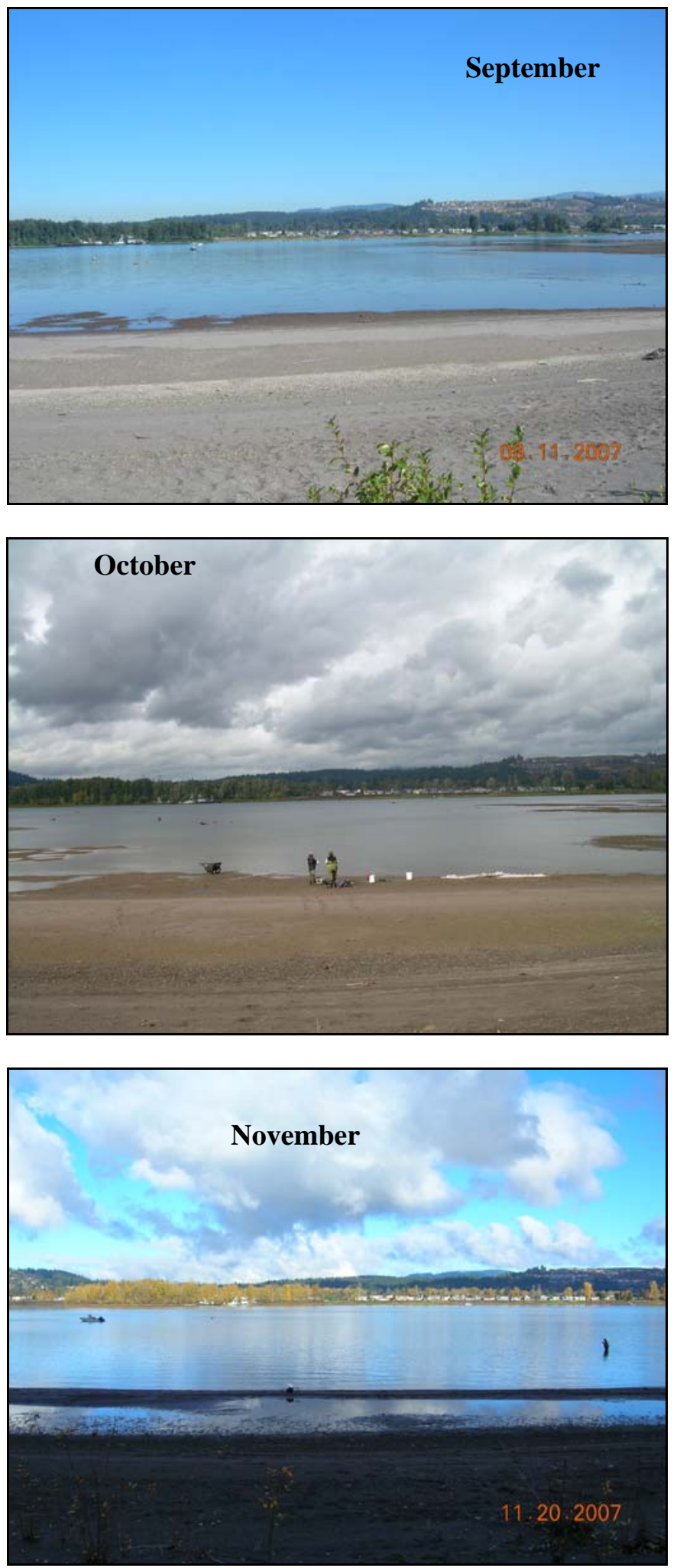

D.4 


\section{Site E}
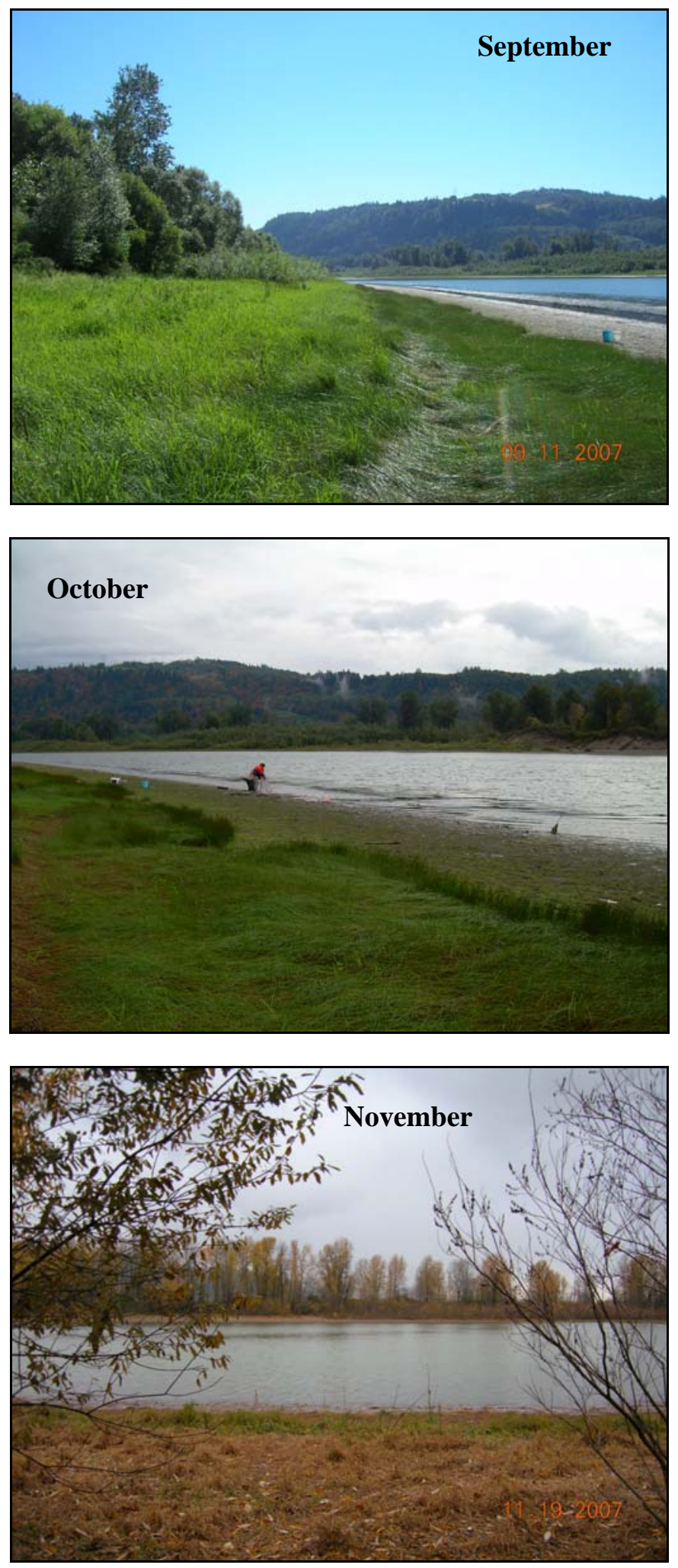

D.5 
Site $\mathbf{N}$
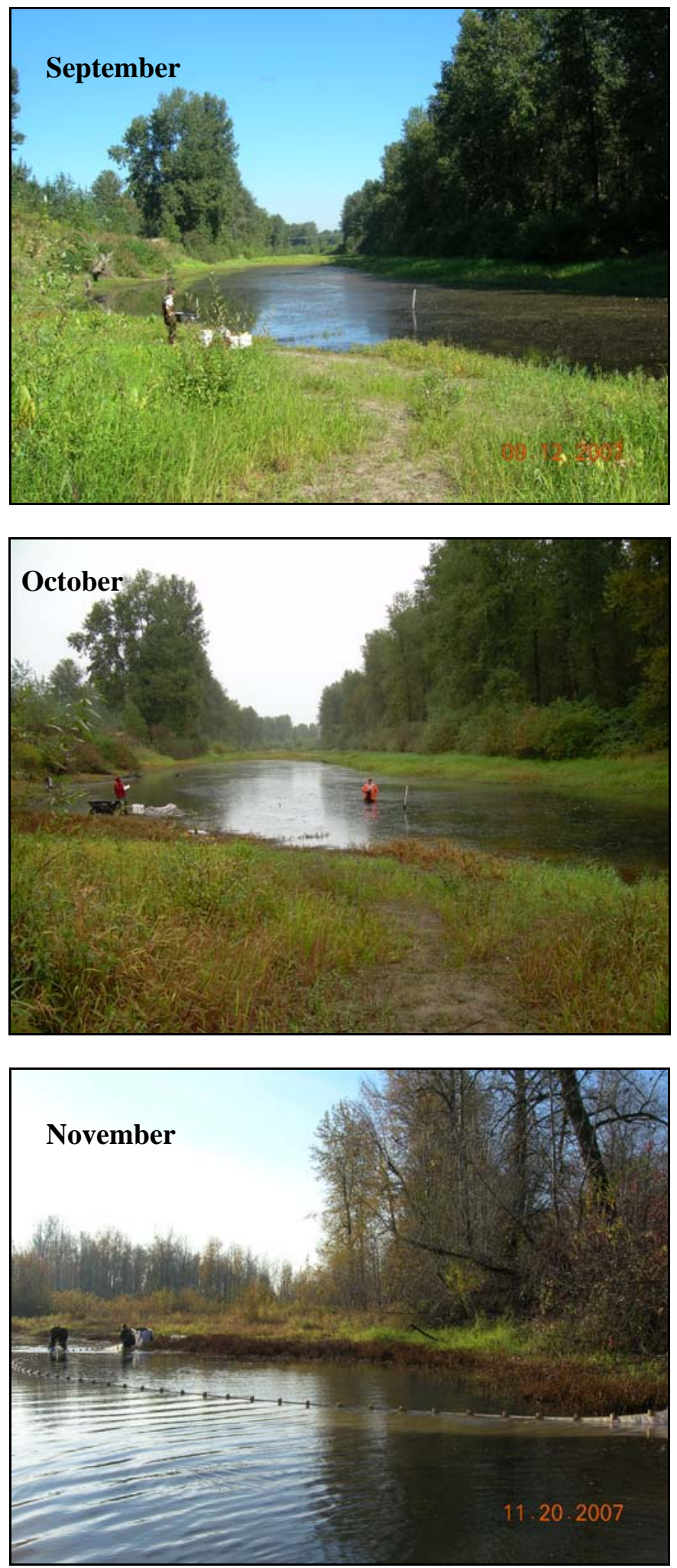

D.6 


\section{Appendix E: Beach Seine Comparison}

This appendix summarizes results of a gear comparison experiment conducted by the field crew February $12-14^{\text {th }}$, 2008. Concerns about the efficiency and lack of repeatability of the KS-9 beach seine being used to collect fish for the Tidal Freshwater Monitoring (TFM) Study during 2007 prompted a gear comparison experiment to evaluate alternate methods. This experiment was conducted during a time of low fish abundance, so statistical analyses will not be appropriate to compare gear-types using catch variation. However, qualitative observations were made by the crew and the results of this comparison will be discussed at the March 4, 2008 team meeting.

\section{Objective}

Test different net types and protocols to determine if improvements can be made to the existing net/protocol combination to maximize efficiency and control bias during monthly fish sampling for the TFM Study.

\section{Methods}

We assessed four haul techniques using two distinct nets for our gear comparison experiment.

\section{KS-9 Beach Seine}

This is the net currently used in the TFM Study. The KS-9 is a bagless beach seine ( $30.5 \mathrm{~m} \times 3$ m; $5 \mathrm{~mm}$ bar knotless mesh) constructed by Memphis Net and Twine. The net is set by foot or by boat depending on water depth.

When set by foot, this net is deployed by holding one end on shore, while another staff member walks the leading end of the net to the deepest extent possible (1-1.5 m) or approximately 2/3 the distance of the net before turning and hauling it parallel to the beach. When the full distance has been stretched out, the leading end is brought to shore, pursing the net. When the net is in the water, the lead line is let to float, but it is recovered and pulled beneath the net once haul-back commences and the lead line is near shore.

When set by boat, one end of the net is left on the shore, while the boat operator slowly backs away from the shore while a staff member at the bow of the boat pays the net out. When $2 / 3$ the length of net has been paid out, the boat operator turns to be parallel to the shore and the remaining net is paid out parallel to shore, until just short of the end, when it is directed toward shore.

\section{KS-9 with bridles and $20 \mathrm{~m}$ Haul Lines}

For this haul configuration, the same KS-9 net is used; however, we attached a bridle and $20 \mathrm{~m}$ haul lines. We tested bridle configurations and found that an asymmetric bridle was most successful at keeping the net open. To create this bridle, we attached the haul lines on both ends of the net to the 
lead line. The line from the float line was attached to the base of the lead line, so as to anchor this part of the net and prevent it from collapsing in on itself.

During the gear comparison experiment, this net configuration was set both by foot (site C) and by boat (sites $\mathrm{A}$ and $\mathrm{E}$ ). To set this net by boat, we left one person on shore with the working end of the haul line, while the boat operator slowly backed off the shore line, perpendicular to the beach. At the junction of the haul line and net, the boat turned parallel to the beach and the seine was deployed to its full length. At the tail end of the net, the operator again turned the boat, heading back to shore. This left the net parallel to shore, $20 \mathrm{~m}$ off the water's edge. Once the working end of leading haul line was to shore, both sides of the net were hauled evenly. As the net approached the shore, the teams on both ends moved toward the center creating a purse in the net. The net was hauled evenly, with the lead line down, until it was retrieved completely. The same procedure was followed to set this net configuration by foot; however the net was deployed from a floating cart pulled through the water by two staff members.

\section{Willamette Method, KS-9 with Bridles and 20 m Haul Lines, Immediate Retrieval}

This haul configuration is similar to that previously described; the same KS-9 net is used, with bridles and $20 \mathrm{~m}$ haul lines. The difference is that the haul-back on the trailing edge is initiated once the extent of the haul line has been paid out and the boat turns to set the net. The Willamette method allows for the net to be set further offshore (compared to the standard KS-9 procedure, see number one above), while the immediate haul-back is intended to close the net on the downstream side so that fish escape is minimized. While this method permits the net to be deployed $20 \mathrm{~m}$ offshore, however, due to the uneven hauling the total area swept is smaller compared to methods two and four discussed in this section.

\section{Puget Sound Beach Seine}

The TFM study began using this beach seine that was developed for nearshore fish collection in Puget Sound. It was found to be unfavorable because the mesh size in the wings resulted in some larger salmon (70-90 mm) becoming entrapped, or "gilled," in the mesh. However, this net has been used successfully in the past, is tractable in river situations, and could be made with smaller mesh in the wings.

The net was designed to be $37 \mathrm{~m}$ in length, with $18 \mathrm{~m}$ tapered wings connected to a bag approximately $1 \mathrm{~m} \mathrm{x} 2 \mathrm{~m}$. The wings are $2 \mathrm{~m}$ in height at the bag and taper to $1 \mathrm{~m}$ in height at the ends. The mesh in the wings is designed to be 29-mm stretch mesh and the bag is lined with 6-mm mesh. It is important to note that the wing-mesh on the net we used was larger than the typical Puget Sound Beach Seine, at $65 \mathrm{~mm}$, though the bag mesh was the standard size. The tapered ends are attached to wooden poles and a bridle that keep the float line and lead line evenly separated during haul back. While haul lines are typically $33 \mathrm{~m}$ or more in Puget Sound, we utilized $20 \mathrm{~m}$ lines due to potentially high current. It is also important to note that the model used during our gear comparison experiment was a "sinking” net; these nets are typically configured with additional flotation to sample surface waters. 
The net is preferably set by boat, but can be set by foot. For deployment by boat, one person stands on the beach holding the working end of the first haul line. The boat is moved away from shore until the bridle is reached; the boat is then turned 90 degrees to be parallel with shore and the net is paid out until the second bridle is reached. At this point the second haul line is brought to shore (should be $\sim 37 \mathrm{~m}$ apart from the $1^{\text {st }}$ person). The net is retrieved by hauling equally on both ends, keeping the bag in the center, until the net is $\sim 10 \mathrm{~m}$ from shore. At this point the people on either end approach each other until they are about $12 \mathrm{~m}$ apart; they continue hauling and moving in so the net can be retrieved completely, keeping the lead line in contact with the substrate. The same procedure is followed to set this net configuration by foot; however the net is deployed from a floating cart pulled through the water by two staff members.

\section{Experimental Plan}

We evaluated a total of four gear-types at three sites (Sites A, C, and E) over three days. We hauled each net twice at all sites in a pre-assigned, random order (Table E.1). We had four seine positions, which were each fished twice, for a total of 8 hauls per day at each site.

Table E 1. Sampling order for gear types. Numbers in shaded boxes indicate order of hauls to be conducted (e.g. Hauls 3 and 5 on Day one were carried out using the KS-9 net). Gear types are described above.

\begin{tabular}{l|ccc}
\hline & Day 1 & Day 2 & Day 3 \\
\hline Gear Type & Site A & Site C & Site E \\
& (Boat) & (Foot) & (Boat) \\
KS-9 & 3,5 & 5,6 & 2,6 \\
KS-9 w/ Bridles & 1,6 & 1,3 & 3,4 \\
KS-9 Willamette & 4,8 & 4,7 & 1,8 \\
Puget Sound & 2,7 & 2,8 & 5,7 \\
\hline
\end{tabular}

We selected sites A, C, and E for the following characteristics: at Site E it is always necessary to set the net by boat due to deep water; Site $\mathrm{C}$ is generally shallow, especially at low river stage, and the net typically must be set by foot; and at Site A water level is intermediate; the water level at the time of sampling determined that the net be set by boat. Nets were set by boat or on foot depending on water level, and the deployment mode was consistent for all hauls at a given site (Table 1). We made four discreet non-overlapping seine hauls and then returned to the initial position (we estimated 30 minutes/haul, with the time elapsed since the original seine being about 2 hours). This allowed us adequate beach length to conduct two sets of comparisons with enough time for fish to redistribute themselves at the site between hauls 1 and 5 so that re-use of sites did not likely bias our results.

Specific Sampling Concerns: 
- Net sets and haul-back must be as consistent as possible

- Sampling area must be left as undisturbed as possible (especially when transporting gear to beach and setting the net)

- Discrepancies between boat-sets and foot-set may skew data-may wish to test this hypothesis if time allows or if there is another opportunity (probably unavoidable given sites and river level through time)

\section{Results}

We completed the 24 hauls as scheduled for the gear comparison. Fish abundances were low in general, with several young of the year $(<50 \mathrm{~mm})$ Chinook salmon and two likely $1+(75-85 \mathrm{~mm})$ coho salmon present, but no larger salmon. Other species captured included banded killifish, threespine stickleback, largescale sucker, yellow perch, northern pikeminnow, redside shiner, and starry flounder. Several hauls included sizeable $(200+\mathrm{mm})$ mountain whitefish, however these were the only larger fish captured.

Nets

All the nets performed well at our sites in terms of deployment and retrieval. These sites were selected with beach seine gear in mind, so they are suited to beach seines in general. The KS-9 deployment by boat presents some challenges for the boat operator- - to bring the net back to the beach and maneuver the boat without fouling the net can be difficult when maneuverability is limited by depth or current. The KS-9 net can also roll onto itself in shallow water; while this does not present a significant problem, it is noteworthy when SAV is abundant, as contact with the substrate is inconsistent.

The Willamette and KS-9 w/ Bridles are similar methods and both worked well with the asymmetric bridle rigging. The haul lines provided the opportunity to sample further offshore, during many instances in deeper water. In deploying both these types, it is necessary to keep the lead line on the inside as the boat makes the turn to parallel the beach—-this prevents a twist from occurring.

The Puget Sound beach seine was most consistent in setting, since the wooden poles kept the net spread and the heavy lead line caused it to sink immediately upon deployment. The weight of the lead line did result in some fouling due to sediment. Whether to fish this net as a sinking seine or a floating seine would be a point of discussion should the research team elect this gear-type.

Fish

Due to limited fish abundance, data regarding captured fish is unlikely to illustrate a preferred gear-type. In comparing the raw number of fish caught with each gear-type, the Puget Sound net captured the highest mean number of fish per haul (14), while the Willamette type set captured the lowest (3.8, Figure E1). 


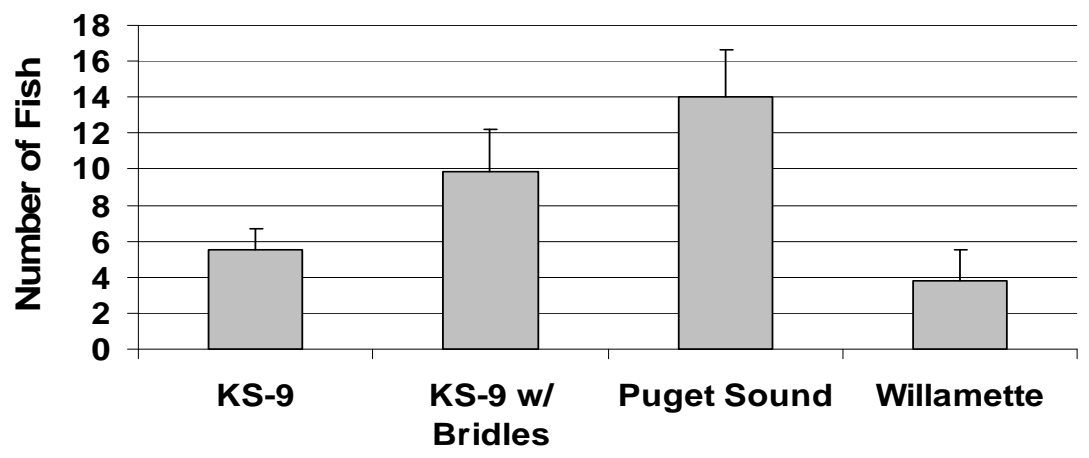

Net Type

Figure E 1. Mean number of fish caught with each gear-type. Error bars represent one standard deviation from the mean.

Numbers of fish collected is only part of the concern, as the research team desires a true representation of the assemblage in shallow water areas. The fish species captured during our experiment were all captured during our regular sampling period. There was little difference in the number of species collected with the different gear types, though the Puget Sound seine collected the greatest mean number of species (5) and the Willamette method caught the fewest (2.2, Figure E.2).

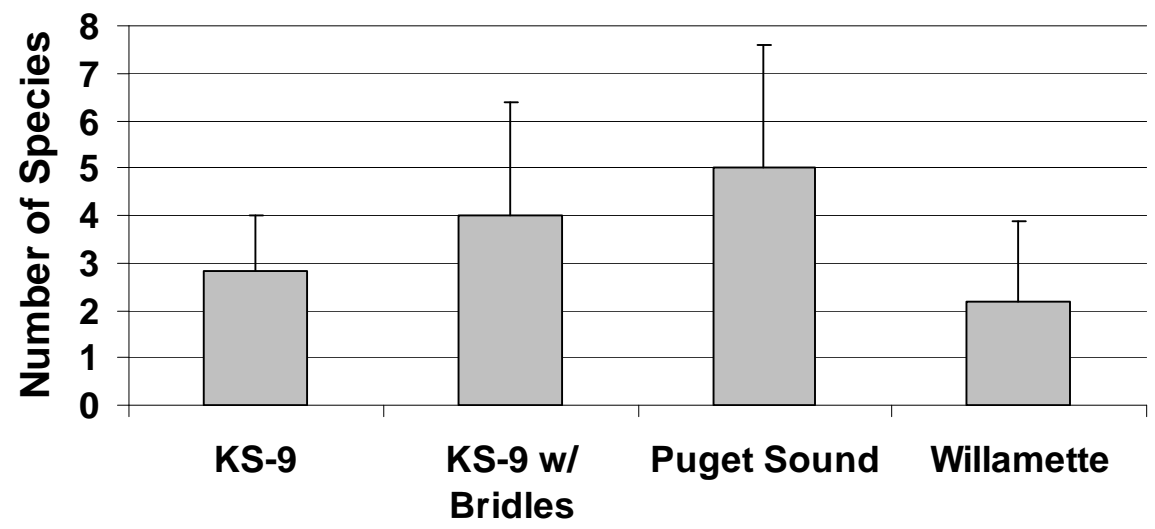

Net Type

Figure E 2. Mean number of species captured by each gear-type. Error bars represent one standard deviation from the mean. 


\section{Conclusions}

While all the nets and configurations seem to capture shallow tidal freshwater species, the field team felt that the addition of haul lines on the KS-9 net (KS-9 w/ Bridles) and the Puget Sound beach seine resulted in more consistent sets. Additionally, the haul lines resulted in the net being deployed at a consistent distance from shore and further offshore than the KS-9 net the team has been using. The technique of hauling the net immediately, as in the Willamette set, seemed to make little difference and may introduce greater variability in the consistency of the size and dimensions between hauls.

While catch data indicate that the Puget Sound beach seine may capture a greater number of fish, larger fish, and a more diverse assemblage, the limited number of captured fish in each seine made statistical analysis inconclusive (ANOVAs on mean number of fish by net type and mean number of species by net type showed p-values to be greater than 0.05 , with high variances). Performing this same experiment when more fish are present at the sampling sites (seasonal differences) may illustrate more conclusive differences between gear-types. Additionally, because of constraints related to water depth and lack of fish captured, we were unable to compare sampling performance when nets were deployed by boat versus foot at the same site. Future gear suitability studies should attempt to assess this comparison as the information might help to validate our use of variable deployment modes among sites and sampling periods.

Regardless of the lack of statistical significance, our qualitative observations provide sufficient evidence to adjust the current beach seine method used in this study. The recommendations of the field team are to modify the KS-9 by adding bridles and haul lines or to employ a modified Puget Sound beach seine, whereby the mesh size in the wings is smaller to prevent incidental mortality due to "gilling," as was previously observed. 